RENAN HONÓRIO QUINALHA

\title{
JUSTIÇA DE TRANSIÇÃO: CONTORNOS DO CONCEITO
}

\author{
DisSERTAÇÃO DE MESTRADO
}

ORIENTADOR: PROFESSOR TITULAR

JOSÉ EDUARDO CAMPOS DE OLIVEIRA FARIA

FACULDADE DE DIREITO DA UNIVERSIDADE DE SÃo PAULO SÃO PAULO

2012 
RENAN HONÓRIO QUINALHA

\title{
JUSTIÇA DE TRANSIÇÃO: CONTORNOS DO CONCEITO
}

\begin{abstract}
Dissertação apresentada como requisito parcial para a obtenção do título de Mestre, junto ao Departamento de Filosofia e Teoria Geral do Direito da Faculdade de Direito da Universidade de São Paulo.
\end{abstract}

ORIENTADOR: PROFESSOR TITULAR JOSÉ EDUARDO CAMPOS DE OLIVEIRA FARIA

FACULDADE DE DIREITO DA UNIVERSIDADE DE SÃo PAULO SÃO PAULO 2012 


\section{JUSTIÇA DE TRANSIÇÃO: CONTORNOS DO CONCEITO}

Dissertação apresentada como requisito parcial para a obtenção do título de Mestre, junto ao Departamento de Filosofia e Teoria Geral do Direito da Faculdade de Direito da Universidade de São Paulo.

Orientador: Professor Titular José Eduardo Campos de Oliveira Faria

Aprovado em:

BANCA EXAMINADORA

Prof.

Instituição:

Julgamento: Assinatura:

Prof.

Instituição:

Julgamento: Assinatura:

Prof.

Instituição:

Julgamento: Assinatura: 
Aos que buscaram a justiça, sem adjetivos. Por mais inviável, inoportuno ou inadequado que parecesse o momento. 


\section{AGRADECIMENTOS}

Os momentos finais de conclusão de um trabalho intelectual acabam deixando a impressão de que a ciência, inevitavelmente, é um fazer solitário. No campo das ciências humanas, a convivência intensa entre o autor e o seu texto, que materializa determinado esforço de pesquisa e de reflexão em cima de conceitos, aparece como o autêntico ato científico. Ou, pelo menos, para não pecar pelo exagero, como seu ponto mais alto ou momento mais característico. No entanto, essa dissertação é o resultado de uma trajetória que se arrastou por longos anos, a despeito do curso do mestrado durar apenas trinta e seis curtos meses.

Sem dúvidas, o texto que segue carrega muito da reflexão pessoal de quem o escreveu. Mas quem a escreveu, por sua vez, carrega ainda mais dos caminhos que andou percorrendo.

Isso posto, o que então poderia soar, à primeira vista, como um isolamento, dá lugar à verdadeira natureza de uma experiência intelectual: a persistente presença do Outro. No sentido lacaniano, aquela ordem simbólica que, quando chegamos ao mundo, já está pronta. É ela que nos atravessa e nos constitui, assim como aportamos algo nosso nela. As manifestações concretas desse outro variam de figuras, mas sempre estão presentes.

Sob essa perspectiva, os agradecimentos são ressignificados. Assim, esta seção tem por função não compartilhar responsabilidades, como quase sempre parece sugerir a parte inicial dos trabalhos acadêmicos. De nada escrito nesta dissertação tenho como ou por que me desresponsabilizar, ainda que saiba de suas deficiências e limitações. Apenas pretendo distribuir, afetuosamente, os reconhecimentos que entendo devidos às pessoas que, cada uma a sua maneira, deram contribuições decisivas para que eu chegasse até aqui, com essas ideias e com este trabalho.

Em primeiro lugar, o obrigado vai ao meu orientador, Professor José Eduardo Faria, que tão bem tolerou minhas impertinências e confusões. Desde o segundo ano de minha graduação na Faculdade de Direito, no ano de 2005, acolheu-me com generosidade no seu Programa Especial de Treinamento (PET-SeSU). Nesse importante espaço, ensaiei alguns primeiros e importantes passos no desafio de formular questões teóricas, pensá-las academicamente e discuti-las entre iguais.

Aos professores Jean-Paul Rocha e Cláudia Perrone-Moisés por terem me convencido, no exame de qualificação, de que era preciso reduzir o tema. 
Ao professor Amauri Mascaro Nascimento que, desde 2008, com sua generosidade ímpar, tornou mais leve a sempre difícil conciliação entre trabalho e estudo acadêmico. Também lhe devo importantes lições aprendidas, na vida e no direito do trabalho. A Claudete Vasconcellos, pela ajuda de sempre.

A Edilene Santos, que veio de Belém deixar São Paulo mais alegre. Também deixou este texto mais correto com sua impecável revisão gramatical.

A Bianca Galafassi, pela ajuda fundamental na formatação e revisão tão atentas e profissionais do trabalho. Não fosse ela, o resultado final teria menos rigor e beleza.

A Tânia Gerbi Vieira, pela leitura tão cuidadosa do trabalho. Também ao Núcleo de Preservação da Memória Política, pelos debates importantes que promove.

A Rachelle Balbinot, pela ajuda na saga em busca da Espada de Dâmocles e, em especial, pelas tardes e noites de companhia na biblioteca.

Ao pessoal do movimento estudantil, nomeadamente do "Fórum da Esquerda", com quem aprendi, intensamente, que justiça se busca em grupo: Gabriel Muniz, Pablo Biondi, Vinícius Mota, Luiz Mendonça, Paulo Leonardo Martins, Renan Kalil, Ricardo Ribeiro, Veridiana Alimonti, Zeca Callegari, Gustavo Seferian, Álvaro Pereira, Thiago Barison, Walter Andrade, Lívia Gimenes, Fernando Rugitsky, Marcele Guerra, Ester Rizzi, Bruno Lupion, Marina Menezes, Silas Cardoso, Regina Vieira, Flávio Prol, Francisco Brito Cruz e outros tantos que marcaram esse momento fundamental da minha formação pessoal.

Também a Lucas Oliveira, Débora Arakaki, Alexandre Loureiro, Samuel Ramos, Mari Flesch, Gladston Viana, Camila Baraldi, Danilo Cymrot, Bianca Tavolari, Igor Rolemberg, Mari Guarda, Mari Valente, Guilherme Giufrida, João Turchi e Walküre Lopes. A convivência com vocês me propiciou trocas e distrações que constituíram intervalos alentadores durante esse processo. Pela visita na Argentina, Rafaela Barbosa, Mari Carrara, Mari Guarda e Lucas Fábio, que ajudaram no estudo de campo. Ele acabou saindo dessa pesquisa, mas a amizade, que é mais importante, ficou.

Aos membros do Grupo de Estudos sobre Internacionalização do Direito e Justiça de Transição (IDEJUST), agradeço nas pessoas de meus colegas de diretoria: Paulo Abrão (CA/MJ), Marcelo Torelly (CA/MJ), Marcelo Cattoni (UFMG), Katya Kozicki (UFPR), José Carlos Moreira da Silva Filho (PUC/RS) e Deisy Ventura (IRI/USP). A esta, em especial, por ter me convencido de que este tema valia a pena e, sobretudo, pela confiança depositada em mim, desde o começo. 
A Inês Virgínia Prado Soares, Paula Sachetta, Raphael Neves, Christian Jecov, Rafael Schincariol, Fábio Bon e Daniel Fabre, pelas intrigantes conversas e parcerias envolvendo esse tema.

Ao Eduardo Ariente, Maria Inês Miya Abe, Tarso de Melo e Vinícius Casalino, por terem estimulado um jovem graduando ao caminho da pós-graduação.

A Gabriela Amaral e ao pessoal do Instituto Sedes Sapientiae, pelas discussões semanais de psicanálise que me levaram a compreender que, por detrás de conceitos e teorias, estão, em verdade, as questões humanas mais essenciais.

A Amelinha Teles e Criméia de Almeida Schmidt, pelo exemplo de coerência, persistência e ternura na luta por justiça.

Ao Edson Teles (UNIFESP), pela singular coerência com que vive e pensa esse tema. Especialmente, sou-lhe grato pelas conversas e e-mails trocados durante essa pesquisa. A ele devo o desconforto inicial com a aplicação do termo "justiça de transição" ao caso brasileiro e, portanto, todo o rumo que acabei imprimindo para essa dissertação.

No curso de graduação em Ciências Sociais da FFLCH/USP, meu segundo paradeiro, ao professor Cícero Araújo, que ministrou uma disciplina com referências fundamentais para minhas reflexões. Lá, também, a Juliana Bueno, pela amizade, pela troca de ideias e pela companhia nas horas de biblioteca.

Aos funcionários das bibliotecas Florestan Fernandes (FFLCH/USP) e Mário de Andrade, lugares cujas tranquilidade e organização tornaram este trabalho possível.

Por fim e mais importante, à minha família, sempre presente: antes, durante e depois de terminado este trabalho. Angelo, Ivone e Rodrigo são três referências e apoios imprescindíveis em meu percurso. Também Teresa, pelos "Honórios", e Irene Galucci, pelos "Quinalha”, representando minhas duas origens. Generosamente, essa família abriu mão, na medida do possível e não sem reclamações, do tempo de convivência que este trabalho lhes roubou. 
Quanto a mim, eu não tinha dúvida, na época, de que a todo momento cada um de nós, homem, mulher, criança, talvez até o pobre cavalo velho que gira a roda do moinho sabia o que era justo: todas as criaturas vêm ao mundo trazendo com elas a lembrança de justiça.

J. M. Coetzee. À espera dos bárbaros, p. 183.

Quando os dias sem notícia se tornam semanas, o pai à procura da filha grita, destemperado; importuna, incomoda com a sua desgraça e suas exigências impossiveis de justiça.

Bernardo Kucinski. K., p. 89-90. 
The Sword of Damocles

A Espada de Dâmocles - Richard Westall, 1812.

Ackland Art Museum

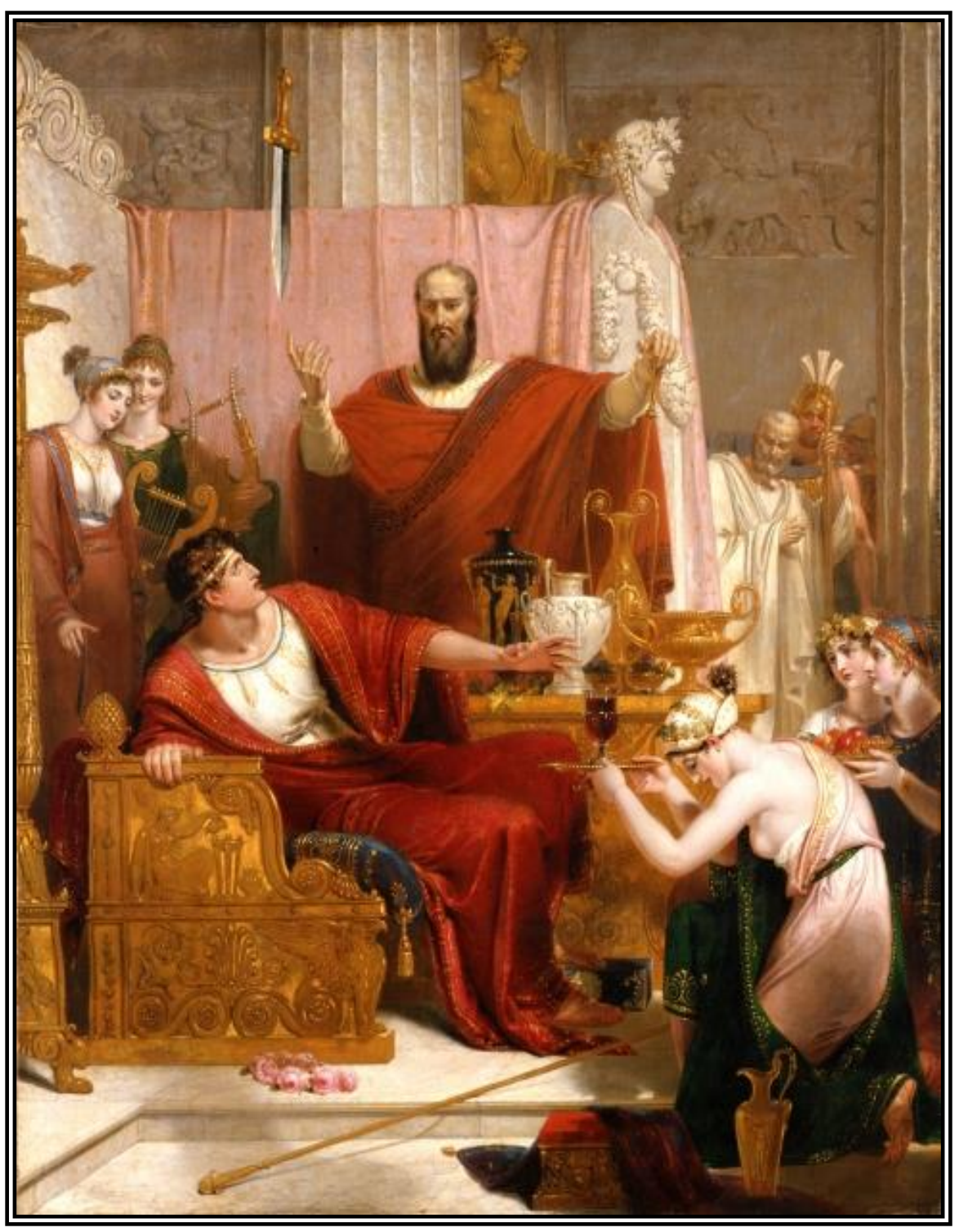




\section{RESUMO}

A presente dissertação tem por objeto uma análise crítica do conceito de justiça de transição. Surgida na fronteira do direito com a ciência política, a partir da década de 90 do século XX, essa expressão tem delimitado um novo campo de reflexões e uma profícua agenda de pesquisas interdisciplinares na teoria social contemporânea. Para compreendê-la devidamente, esse trabalho faz um percurso incomum nos estudos da área. De partida, para recuperar as origens mais imediatas e pouco lembradas desse conceito, procede-se a uma revisão analítica da literatura produzida por uma geração importante de cientistas políticos durante as décadas de 80 e 90, conhecida como "transitologia". Essa tradição preocupavase, essencialmente, em apreender a excepcionalidade dos momentos transicionais e em evitar, a todo custo, que se consumasse uma regressão autoritária, razão pela qual recomendavam todos os tipos de cautelas e prudências possíveis aos atores políticos. Após um exame detido desse corpo teórico, destacando suas premissas e definições, bem como limitações, discute-se o que se pode considerar, nesse quadro conceitual, como uma transição justa. Esse é o germe da ideia que, posteriormente, foi recuperada e sistematizada sob o recorte temático da justiça de transição, mas já em um contexto de globalização e internacionalização dos mecanismos de proteção aos direitos humanos. A partir dessas mudanças contextuais e conceituais, torna-se então possível descrever os traços gerais da abordagem tradicional desse fenômeno, estruturada a partir de cinco eixos consagrados nessa literatura: verdade, memória, reparação, justiça e reformas das instituições. Em seguida, são repassadas uma-a-uma as principais críticas dirigidas à definição tradicional, bem como as propostas formuladas para superar as deficiências teóricas e analíticas apontadas. Por fim, depois de examinar os estágios de uma transição e os requisitos para que se consume uma consolidação democrática, questiona-se a pertinência de utilização da expressão justiça de transição para contextos em que vigoram democracias relativamente bem consolidadas. De acordo com essa tese, estrutural para essa pesquisa, o conceito de justiça de transição, por definição, carrega uma ideia de justiça excepcional e precária, a ser modulada de acordo com as possibilidades em condições adversas, que é aplicável apenas a situações de extremo conflito ou forte instabilidade política, não verificadas nos países da América Latina e do Sul da Europa atualmente.

Palavras-chave: Justiça de transição, direitos humanos, transição política, consolidação democrática. 


\begin{abstract}
The purpose of this dissertation is to critically analyze of the concept of transitional justice. Emerging from the intersection between Law and Political Science, from the 1990's on, this expression has defined a new field of reflections and has become a main issue in the growing interdisciplinary research agenda in contemporary social theory. To understand this concept properly, this work takes an unusual path, when compared to the studies in this area. Firstly, to retrieve the most immediate and the least remembered origins of this concept, this dissertation comes to an analytical review of the literature of an important generation of political scientists during the 80's and 90's, known as "transitologists". The "transitology" generation was concerned, essentially, with investigating the exceptionality of moments of transition and with preventing, at all cost, an authoritarian regression, which was why they recommended much caution and prudence to all political actors. After a close examination of this theoretical framework, showing its assumptions and definitions, as well its limitations, this dissertation discusses what can be considered in this conceptual framework as a fair transition. This is the embrionary idea of that was later recovered and systematized under the main theme of transitional justice, but already in a context of globalization and internationalization of the Human Rights protection mechanisms. From these contextual and conceptual changes, it has thus become possible to describe the general features of the traditional approach to this phenomenon, structured by five areas: Truth, Memory, Repair, Justice and Reform of the Institutions. The established definition is revised with the support of a critical analysis, as well as the proposals to overcome the theoretical and analytical deficiencies were pointed out. Finally, after examining the stages of a transition and the requirements for the consummation of democratic consolidation, the appropriateness of the use of the term "transitional justice" for contexts of relatively wellestablished democracies is discussed. According to a theory, which is essential to this research, the concept of transitional justice, by definition, carries an idea of exceptional and precarious justice to be modulated according to the possibilities of adverse conditions, which applies only to situations of extreme conflict or political instability, something that currently cannot be observed in the contexts of Latin America and Southern Europe.
\end{abstract}

Keywords: Transitional justice, human rights, political transition, democratic consolidation. 


\section{SUMÁRIO}

\section{TRANSIÇÕES COMO CONTINGÊNCIAS POLÍTICAS.......................... 20}

1.1 Os primeiros estudos sobre transições e seus cânones............................................................ 22

1.2 O que define uma transição: a incerteza constitutiva........................................................... 27

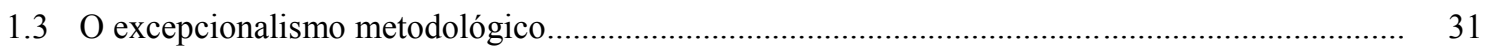

1.3.1 Suspensão das estruturas e os limites nacionais nas transições...................................... 33

1.3.2 O jogo das elites políticas: escolha racional e institucionalismo estratégico................. 38

1.3.3 Os atores políticos e a trama da transição................................................................... 42

1.4 Modos de transição: a preferência pelos pactos democratizadores................................................ 48

1.4.1 Revendo os pactos políticos.................................................................................. 54

\section{A TRANSIÇÃO JUSTA: ENTRE AS DEMANDAS MORAIS E O} IMPERATIVO DE ESTABILIZAÇÃO POLÍTICA........................................ 59

2.1 A ameaça da regressão autoritária: a espada de Dâmocles na transição...................................... 59

2.1.1 Transições negociadas e o risco da "morte lenta" da democracia.................................. 64

2.1.2 Os interesses fundamentais do bloco autoritário........................................................ 66

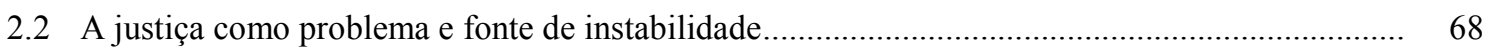

2.2.1 As violações aos direitos humanos e os interesses fundamentais................................... 72

2.2.2 Então quando julgar?....................................................................................... 76

2.3 Justiça de transição: preenchendo uma lacuna......................................................................... 80

2.3.1 A demarcação do novo campo: um conceito de justiça de transição.............................. 83

2.3.2 O reenquadramento da justiça em uma era pós-westfaliana......................................... 85

2.3.3 A concepção tradicional da justiça de transição......................................................... 92

2.3.3.1 Os eixos principais: verdade, memória, justiça, reparação e reformas institucionais.......... 93

2.3.4 Classificação das abordagens tradicionais: entre a moral, o direito e a política............. 104

2.3.5 Críticas às abordagens tradicionais da justiça de transição.......................................... 107

2.3.5.1 A normatividade e a universalidade dos modelos........................................................ 109

2.3.5.2 Uma justiça de transição "desde baixo" ..................................................................... 113

2.3.6 Uma justiça excepcional ou ordinária?................................................................. 114

2.3.7 Uma justiça de compromisso: entre a necessidade e a possibilidade............................. 117 


\section{A JUSTIÇA ENTRE A TRANSIÇÃO E A CONSOLIDAÇÃO:}

A EXCEÇÃO E A REGRA.......................................................................... 122

3.1 Estágios da transição: liberalização e democratização................................................................ 122

3.1.1 O primeiro passo: a liberalização do regime............................................................ 123

3.1.2 O segundo passo: a democratização......................................................................... 125

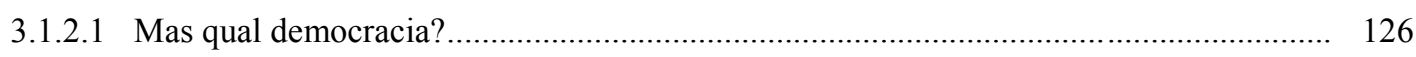

3.1.2.2 Críticas à concepção minimalista da democracia....................................................... 132

3.1.3 Relações entre liberalização e democratização........................................................... 138

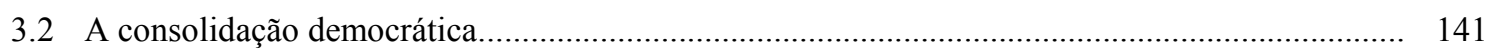

3.2.1 Quando a transição chega ao fim.......................................................................... 141

3.3 A normalização metodológica........................................................................................ 147

3.4 Justiça de consolidação? Ou apenas justiça? ........................................................................... 150

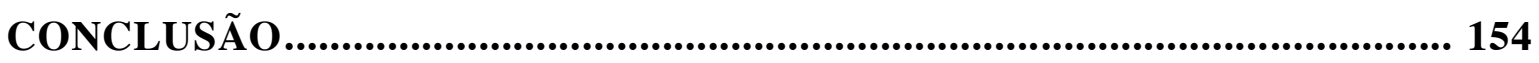

REFERÊNCIAS BIBLIOGRÁFICAS..................................................................... 163 


\section{INTRODUÇÃO}

Durante o ano de 2011, os inesperados colapsos de diversos governos autoritários do Oriente, precipitados pela mobilização política de enormes contingentes de pessoas nas ruas, surpreendeu o Ocidente. A chamada "Primavera Árabe"1 recolocou, na ordem do dia da comunidade internacional, um tema que se pensava adormecido há algum tempo: a discussão em torno da mudança entre regimes políticos.

Com efeito, esse tema fora amplamente discutido após as transições políticas ocorridas na Europa mediterrânea, na América Latina e Leste Europeu, dando origem a uma literatura considerável no campo da ciência política. Com a estabilização de regimes democráticos, no entanto, esses teóricos, que sempre privilegiaram o tempo presente, migraram desse campo, que já parecia esgotado, para outro território: o da consolidação das novas democracias.

Mas se é verdade que os debates em torno das transições políticas estavam relegados a um segundo plano nos últimos anos, o mesmo não se pode dizer da justiça de transição. Trata-se de um conceito de ampla repercussão nas atuais discussões jurídicas e políticas, dentro e fora do Brasil.

As questões práticas e teóricas postas pela transição e consolidação democráticas, em especial aquela mais recente relativa às medidas de justiça em relação às violações que foram praticadas pelos regimes autoritários, têm ocupado lugar de destaque em diversas disciplinas da teoria social, desde a ciência política até o direito, passando pela sociologia e até mesmo por diferentes ramos da psicologia, tal como a psicanálise ${ }^{2}$.

Não há dúvidas de que os traços de permanência das ditaduras que assolaram o Cone Sul constituem um exemplo privilegiado e mais avançado dessa tendência geral. Essa preocupação em retomar um tema à primeira vista resolvido ou, ao menos, de um passado já tão longínquo, manifesta, de certo modo, a dificuldade de elaboração social e coletiva de um passado traumático.

\footnotetext{
1 Trata-se das enormes mobilizações populares nos países do Oriente Médio e do Norte da África, que derrubaram diversos governos.

2 Em nosso país, exemplos de coletâneas com viés transdisciplinar começam a multiplicar-se. Ver, por exemplo, TELES, Edson; SAFATLE, Vladimir (Org.). O que resta da ditadura. Coleção Estado de Sítio. São Paulo: Boitempo, 2010. SANTOS, Cecília Macdowell; TELES, Edson; TELES, Janaína de Almeida (Org.). Desarquivando a ditadura: memória e justiça no Brasil. v. I e II. São Paulo: HUCITEC, 2009 e SOARES, Inês Virginia Prado; KISHI, Sandra Akemi Chimada (Coord.). Memória e Verdade: A justiça de transição no Estado democrático brasileiro. Belo Horizonte: Fórum, 2009.
} 
Como é sabido, a violência foi amplamente utilizada como instrumento de estabilização política pelas ditaduras civis-militares desses países, com o objetivo autodeclarado de promover uma ideologia securitária baseada nos valores nacionais e na moral cristã ${ }^{3}$. É notório o fato de que o Cone Sul foi assolado por uma onda de regimes ditatoriais muito semelhantes, instaurados em sua origem a partir de golpes que contaram com apoio e, na maior parte das vezes, com o efetivo protagonismo das corporações militares, treinadas no exterior em um contexto de Guerra Fria e inspiradas pela ideologia de segurança nacional.

Constata-se, com clareza, que o autoritarismo assumiu uma dimensão regional que, a despeito das particularidades, valeu-se de métodos de repressão comuns, sendo exemplo maior dessa transnacionalidade o que ficou conhecido como Plano Condor. Desnecessário apontar, aqui, as impressionantes cifras de presos, mortos e desaparecidos políticos que sofreram com os atos de repressão e exceção.

Por certo, é difícil, senão impossível, definir com precisão o quanto a experiência social de regimes autoritários do passado se presentifica de modo a obstaculizar, ainda hoje, a melhora na qualidade da democracia nesses países. Também é difícil estimar, com exatidão, o quanto uma cultura de impunidade, que afeta a legitimidade e a efetividade do direito e de suas instituições, vem sendo alimentada pela ausência - ou pela insuficiência de medidas destinadas a reparar esses graves abusos de direitos humanos do passado.

Contudo, é forçoso admitir que o presente dessas nações ainda se apresenta bastante marcado pelo signo da violência, nos mais diversos âmbitos da vida social e não apenas na relação do Estado com a sociedade civil. Um dos exemplos mais notórios é o modus operandi e as torturas até hoje praticadas pelas polícias brasileiras, mas não se pode olvidar das microrrelações de autoritarismo imersas no cotidiano, que perpetuam violações sistemáticas aos direitos fundamentais de diversas minorias.

Nesse sentido, em missão realizada no Brasil de 07 a 14 de março de 2007, o relator especial de execuções extrajudiciais, sumárias ou arbitrárias da Organização das Nações Unidas (ONU), Dr. Philip Alston, constata que o Brasil tem um dos mais elevados índices de homicídios do mundo, com mais de 48.000 pessoas mortas a cada ano, destacando a violência policial e a atuação de milícias e grupos de extermínio como as causas centrais dessa cifra elevada. Nesse mesmo documento, aponta resquícios do

\footnotetext{
3 Para um exame detido dos traços gerais dessa doutrina, bem como das feições particulares que assumiu em cada uma das nações latino-americanas, ver COMBLIN, Pe. Joseph. A ideologia da segurança nacional: o poder militar na América Latina. Rio de Janeiro Civilização Brasileira, 1978.
} 
autoritarismo do passado nesse contexto presente, ao afirmar que "os brasileiros não lutaram bravamente contra 20 anos de ditadura, nem adotaram uma Constituição Federal dedicada a restaurar o respeito aos direitos humanos apenas para que o Brasil ficasse livre para que os policiais matassem com impunidade, em nome da segurança"״4.

Merece menção também o relatório Força Letal: Violência Policial e Segurança Pública no Rio de Janeiro e em São Paulo, elaborado pela organização Human Rights Watch, divulgado em dezembro de 2009. Fundado em uma pesquisa empírica sobre os sistemas de segurança pública paulista e carioca, o relatório constata que "os dados são alarmantes. Desde 2003, as polícias do Rio e de São Paulo juntas mataram mais de 11.000 pessoas" . Não bastasse a situação de extrema violência que se perpetua, segundo esse estudo, a impunidade das forças militares também continua, pois "os dados estatísticos oficiais disponíveis apoiam a visão de que a impunidade em casos de abuso cometidos por policiais é a regra"6.

Esses laços de continuidade nos países latino-americanos são facilmente compreensíveis. Entre nós, prevaleceu no registro histórico um balanço oficial que atenuou o sentido forte de transições democráticas. Ressignificaram-se esses processos de luta por redemocratização como se fossem meras aberturas políticas, algo que, em grande medida, limitou o alcance das medidas de justiça e de memória que se seguiram. Isso porque, nesse contexto, os governos democráticos, premidos entre a necessidade de reformas sociais e as pressões por estabilização econômica, imperativos de difícil conjugação e harmonização, viram-se enfraquecidos e incapazes de romper mais aberta e diretamente com as heranças autoritárias e com os resíduos de poder preservados pelos setores sociais que apoiaram o regime ditatorial.

Nessa linha, ainda que não se possa traçar uma relação de causalidade exclusiva e imediata, impossível seria, também, dissociar as limitações dos processos democráticos dessas sociedades em relação às experiências de autoritarismo recentemente vividas, como se esses fatores fossem independentes entre si.

Esse argumento sustenta-se, também, pela persistência de uma cultura políticojurídica ainda atrelada a um autoritarismo instrumental de grande fôlego na América

4 ALSTON, Philip. Relatório do Relator Especial sobre Execuções Extrajudiciais, Sumárias ou Arbitrárias. 2008. p. 6. Disponível em: <www.nevusp.org/downloads/relatoriophilip.doc>. Acesso em: 15 jan. 2012.

5 HUMAN RIGHTS WATCH. Força Letal: Violência Policial e Segurança Pública no Rio de Janeiro e em São Paulo. 2009. p. 1. Disponível em: <http://www.hrw.org/node/87056>. Acesso em: 15 jan. 2012.

6 HUMAN RIGHTS WATCH. Força Letal, p. 6. 
Latina e que não foi, em grande medida, desativado, a despeito dos avanços mais recentes no sentido de afirmar um estatuto constitucional real para esses Estados democráticos.

Os próprios sistemas judiciais e as elites judiciárias não passam imunes a processos autoritários, visto que normalmente mantiveram, durante as ditaduras, relações privilegiadas com as corporações militares. Isso é bem analisado em um recente estudo sobre o perfil da atuação dos poderes judiciários durante as ditaduras do Brasil, Chile e Argentina, traçando uma escala entre esses três regimes - em ordem crescente considerando tanto o modo como o judiciário lida com a legalidade do regime anterior (de mais gradualista, no caso brasileiro, até o mais radical no argentino), quanto o grau de tentativa de legalização da repressão (desde mais judicializado, no caso brasileiro, para mais extrajudicial, no argentino). Em ambas escalas, o Chile ocupa posição intermediária ${ }^{7}$.

Ou seja, o Brasil é o exemplo mais notório de repressão com pretensões de legalidade e de judicialização. Em nosso país, houve muitos processos na justiça militar e muitas condenações. Por sua vez, a Argentina sofreu uma repressão que não passava nem perto do poder judiciário, pois prevaleceram os métodos extrajudiciais e, sobretudo, os desaparecimentos forçados. Esse papel dos sistemas judiciais e outras instituições estatais durante os regimes autoritários, combinado com o tipo de transição política efetuada, indicam elementos importantes para a compreensão da atual situação dessas sociedades.

Deve-se destacar que não se compreende o país de hoje sem analisar o direito, seus procedimentos e instituições, além das políticas públicas por ele conformadas e informadas. Por isso, o enfoque da justiça de transição que será apresentado é uma perspectiva privilegiada para compreender como se representa esse passado recente e o que dele sobrevive como legado na própria perpetuação do momento atual.

O recorte analítico adotado, assim, constitui uma chave de leitura para diversos fenômenos sociais e políticos que reproduzem, de algum modo, padrões de conduta e expectativas das culturas política e jurídica herdadas da experiência autoritária recente. Nessas condições, em que uma série de passivos político-jurídicos é transmitida para as sociedades em democratização, faz-se necessário tratar esse legado para que se possa concretizar plenamente o ideal democrático e republicano.

Não por outra razão, o tema da justiça de transição ingressou, em posição de destaque, na agenda política latino-americana. As discussões relativas ao legado do passado autoritário nessas democracias recentes sempre estiveram em pauta pela

\footnotetext{
7 PEREIRA, Anthony W. Ditadura e repressão: O autoritarismo e o estado de direito no Brasil, no Chile e
} na Argentina. São Paulo: Paz e Terra, 2010. 
persistente atuação de movimentos sociais de ex-presos e de familiares de desaparecidos políticos. Mas essas pautas adquiriram excepcional visibilidade nos últimos cinco anos.

No caso brasileiro, demonstrações contundentes disso podem ser verificadas, especialmente, a partir do ano de 2008. Uma série de iniciativas e respostas recentes por parte do Estado atesta que esse tema começou a ocupar um espaço público relevante e passou a ser objeto de intensas polêmicas na sociedade e no interior do próprio governo.

Nesse sentido, merece menção o lançamento do Terceiro Plano Nacional de Direitos Humanos, instituído mediante o decreto presidencial n. 7037 de 21 de dezembro de 2009, proposto por 31 ministérios, atualizando as versões anteriores e incorporando resoluções diversas da $11^{\mathrm{a}}$ Conferência Nacional de Direitos Humanos, além de propostas aprovadas nas mais de 50 conferências nacionais temáticas promovidas desde 2003 . Nesse documento, um dos pontos mais polêmicos era aquele relativo ao direito à memória e à verdade, previsto no eixo orientador VI e detalhado nas diretrizes 23, 24 e 25.

Outra ação de grande repercussão foi lançada pelo Conselho Federal da Ordem dos Advogados do Brasil (OAB), que propôs, em 21 de outubro de 2008, perante o Supremo Tribunal Federal (STF), em sede de controle abstrato de constitucionalidade, uma Arguição por Descumprimento de Preceito Fundamental (ADPF), com o objetivo de reverter a interpretação até então prevalente no Judiciário segundo a qual a Lei de Anistia de 1979 teria abrangido os agentes públicos que praticaram atos de violação aos direitos humanos. Essa ação foi julgada improcedente por maioria, precisamente sete votos contra dois, em 28 de abril de 2010.

No final desse mesmo ano, em 24 de novembro de 2010, o Estado brasileiro foi condenado pela Corte Interamericana de Direitos Humanos, pelo desaparecimento de aproximadamente 70 vítimas na região norte do país, durante a ditadura civil-militar, o que ficou conhecido como Caso Araguaia ${ }^{8}$. Esse processo tem origem na causa proposta por vinte e dois familiares de desaparecidos políticos perante a Justiça Federal brasileira, em março de 1982, com o objetivo de obterem informações sobre as circunstâncias do desaparecimento forçado de seus entes, além de terem acesso ao corpo dos mesmos ${ }^{9}$.

Essa demanda arrastou-se por décadas até que, em 2005, fosse levada para o sistema interamericano de direitos humanos por iniciativa da unidade brasileira da organização não governamental Centro pela Justiça e Direito Internacional (CEJIL Brasil) e pela Human Rights/Americas, agregando-se posteriormente, como

\footnotetext{
8 Mais exatamente, trata-se do caso Júlia Gomes Lund e Outros contra o Estado Brasileiro, autuado como Demanda n. Caso 11.552 na CrIDH, com sentença de 24 de novembro de 2010.

9 Autos n. I-44/82-B, posteriormente reautuado sob o n. I-108/83, perante a $1^{\text {a }}$ Vara da Justiça Federal do Distrito Federal.
} 
copeticionários, o Grupo Tortura Nunca Mais do Rio de Janeiro (GTNM/RJ) e a Comissão de Familiares de Mortos e Desaparecidos Políticos (CFMDP). Diante das dificuldades de se obter uma resposta satisfatória do Estado brasileiro no sentido de garantir aos familiares as informações, a apuração das circunstâncias e responsabilização dos agentes públicos envolvidos nessa operação repressiva, a Comissão Interamericana de Direitos Humanos propôs ação perante a Corte.

Essa decisão internacional impôs ao Estado brasileiro o dever de investigar e sancionar as graves violações aos direitos humanos referentes ao período da ditadura; determinar o paradeiro das vítimas desaparecidas e, se for o caso, identificar e entregar os restos mortais a seus familiares. Também determinou adotar todas as ações que garantam o efetivo julgamento e, se for o caso, a punição em relação aos fatos constitutivos de desaparecimento forçado por meio dos mecanismos existentes no direito interno; continuar desenvolvendo as iniciativas de busca, sistematização e publicação de toda a informação sobre a Guerrilha do Araguaia, assim como da informação relativa a violações de direitos humanos ocorridas durante o regime militar.

Instalou-se, então, uma situação de constrangimento público sobre o Estado brasileiro, para que passasse a considerar mais seriamente essas questões de direitos humanos. Como decorrência dessa pressão, vieram as recentes promulgações da Lei n. 12.528, que cria a Comissão Nacional da Verdade e a Lei n. 12.527, que dispõe sobre o acesso a arquivos públicos, ambas de 18 de novembro de 2011.

Assim, no interior desse grande campo que está em destaque em nosso país, o principal objetivo deste trabalho é teórico e consiste em compreender a emergência do conceito de justiça de transição, investigando sua estrutura analítica e problematizando sua aplicação a contextos não transicionais.

Para isso, um passo fundamental será traçar os fios que unem a reflexão sobre as transições durante as décadas de 80 e 90 do século passado, com as atuais discussões sobre a justiça de transição, que emergem com vigor e sistematicidade quando da consolidação democrática.

Nesse sentido, o primeiro capítulo é dedicado a recuperar os estudos pioneiros, no campo da ciência política, que foram dedicados ao tema das transições entre regimes. Atenção especial será conferida, nessa parte do trabalho, aos autores integrantes da chamada primeira geração da transitologia, que buscaram compreender as redemocratizações da América Latina e da Europa mediterrânea. 
A despeito das singularidades desses autores, estiveram engajados em um projeto de investigação comum, que incluía um ambicioso estudo de casos. Uma série de premissas, esquemas conceituais e conclusões gerais compuseram um corpo teórico que conferiu unidade a essa tradição. São exatamente esses elementos comuns que serão examinados no capítulo primeiro.

Em seguida, no segundo capítulo, será discutida a ideia de uma transição justa, verificando como essa problemática era contemplada no interior dessa tradição. Preocupados mais com a ameaçadora possibilidade de uma regressão autoritária, por meio de um novo golpe, essa teoria das transições não reservou espaço adequado para as demandas por justiça por parte das vítimas da repressão política e de seus familiares.

A partir dessa constatação, que será melhor demonstrada no transcorrer do trabalho, será possível então compreender a emergência do conceito de justiça transicional, que surge como uma espécie de resposta a essa lacuna, integrando elementos de ordem ética e jurídica aos cálculos dos jogos políticos. Nesse tópico, serão traçadas as linhas de contato que unificam a reflexão sobre as transições e a discussão sobre a justiça transicional, conexão esta pouco mencionada na literatura sobre o tema. Com efeito, nesse aspecto, o objetivo específico é sublinhar os laços que, implícita e explicitamente, conectam essas duas perspectivas teóricas, que têm mais em comum do que se costuma admitir ou supor.

No capítulo terceiro, será analisado o modelo interpretativo que essa tradição formulou para descrever os diferentes estágios ou etapas de um processo transicional típico, quais sejam: liberalização, democratização e consolidação. Um maior destaque será conferido ao ponto último dessa escala evolutiva - a democracia consolidada -, examinando como os estudos da chamada consolidologia demandaram uma normalização metodológica em relação às reflexões sobre as transições.

A partir dessas reflexões, será então possível discutir com maior propriedade sobre os limites e as potencialidades atuais do conceito de justiça de transição, bem como sobre a pertinência de sua aplicação a realidades políticas tão diversas. Nesse ponto, será problematizado o atual estado da arte e as alternativas para superar algumas das insuficiências apontadas. 


\section{TRANSIÇÕES COMO CONTINGÊNCIAS POLÍTICAS}

No presente capítulo, o objetivo central é recuperar os conceitos e a argumentação que estruturam as análises da subdisciplina conhecida como transitologia, para verificar em que medida e de que forma antecipavam tarefas de justiça transicionais e que soluções propunham nesse campo.

Assim, serão reconstituídas diversas questões que estruturaram essas reflexões: por que se desencadeiam as transições, como se desenvolvem e qual sua dinâmica própria; as diferentes modalidades desse tipo de mudança política; a importância dos atores políticos estratégicos; e os desfechos possíveis dos processos transicionais.

Basicamente, as concepções mais tradicionais estavam pautadas em dar conta dos processos transicionais então em curso, operando a partir de distinções e binariedades do tipo "democracia e poliarquia; democratização e liberalização; transição e consolidação; duros e brandos ou acomodacionistas no interior da coalizão autoritária; maximalistas, moderados e oportunistas na coalizão que defende a abertura" ${ }^{\prime 10}$.

Podem-se traçar alguns elementos comuns a essas análises forjadas no calor dos acontecimentos: concepção minimalista, institucional e procedimental (não substancial) de democracia; forte receio da ameaça da regressão autoritária; uma teoria das elites políticas dirigentes e as oposicionistas ao regime autoritário, além das negociações fundantes dos novos regimes dentro dos limites de cada nação, materializados em arranjos institucionais tributários do princípio da soberania territorial; desimportância dos fatores externos às fronteiras de cada país e, sobretudo, dos condicionantes estruturais, que permanecem suspensos. Tudo isso, pelas singularidades, justifica uma excepcionalidade metodológica para abordar esses fenômenos.

Anunciando o plano geral de ambiciosa e paradigmática obra no âmbito dos mencionados estudos sobre transitologia do Woodrow Wilson Center (Projeto Transições

10 LOWENTHAL, Abraham F. Prefácio. In: O’DONNELL, Guillermo; SCHMITTER, Philippe C. Transições do regime autoritário: primeiras conclusões. São Paulo: Vértice; Revista dos Tribunais, 1988 [1986]. p. 12. 
do Regime Autoritário: Perspectivas da Democracia na América Latina e no Sul da Europa), um de seus coordenadores, Abraham F. Lowenthal, afirma que

\begin{abstract}
os casos apresentados demonstram que, embora fatores de ordem internacional, diretos ou indiretos, possam condicionar e afetar o curso da transição, os principais participantes e as influências dominantes foram, em todos os casos, de origem nacional. Eles demonstram a importância das instituições, dos procedimentos de mediação e dos organismos de confronto político que auxiliam a tornar legítimas e dignas de crédito as regras do discurso político num período de mudança. Ilustram o significado vital da liderança e do julgamento político, do papel de indivíduos isolados em complexos processos históricos. Indica, repetidas vezes, a importância da ação realizada no momento certo, a complexidade de processos iterativos realizados em períodos prolongados, as várias formas pelas quais as transições geram surpresas e alguns paradoxos e ironias resultantes ${ }^{11}$.
\end{abstract}

Esse trecho constitui, praticamente, uma síntese do projeto de investigação empreendido por essa geração de cientistas sociais acerca de certas estruturas comuns ou regras mais ou menos universalizáveis das transições que tiveram lugar nos diferentes países latino-americanos.

Antes de passar a uma análise detida dos principais aspectos da teoria das transições, cabe pontuar que, em meio à hoje abundante literatura sobre as transições, terão destaque, neste trabalho, aquelas tidas como as obras paradigmáticas dos autores centrais desse tema. Inevitavelmente, "a ideia do início, o ato de começar, implica necessariamente um ato de delimitação pelo qual algo é cortado de uma grande massa de material, separado da massa e obrigado a representar, bem como a ser, um ponto de partida, um início"12 ${ }^{\text {. O }}$ ponto de partida, que delimitará a problemática, é essencial para designar quais os textos, autores e períodos mais adequados à pesquisa proposta.

O foco será as reflexões daqueles cientistas políticos comumente considerados como os pais fundadores das disciplinas referidas: Adam Przeworski, Guillermo O’Donnell, Laurence Whitehead, Philippe Schmmiter, Samuel Huntington. De algum modo, todos estiveram associados com o mencionado projeto de investigação. Mais ocasionalmente, serão também analisados alguns autores que, apesar de reservas oportunamente indicadas, colaboraram de alguma maneira e adotaram, em suas análises, as premissas centrais da transitologia, como os brasileiros Francisco Weffort e Luciano Martins.

11 LOWENTHAL, Abraham F. Prefácio. In: O’DONNELL, Guillermo; SCHMITTER, Philippe C. Transições do regime autoritário, p. 12 e 13. Conforme ressaltado por esse autor, referindo-se ao projeto, no mesmo prefácio, "trata-se do primeiro livro, escrito em qualquer língua, a enfocar, de modo sistemático e sob uma perspectiva comparativa, o processo de transição de regimes autoritários, fazendo dele a questão central da pesquisa acadêmica, posição que já ocupa no âmbito da política latino-americana” (p. 12).

12 SAID, Edward W. Orientalismo: o Oriente como invenção do Ocidente. São Paulo: Companhia de Bolso, 2007. p. 45. 
Destaque-se que o recorte escolhido justifica-se pelo protagonismo das pesquisas mencionadas. A escolha desses autores decorre da natureza seminal de suas investigações e compõem um quadro relativamente coerente e unitário que dá corpo a algo que se pode designar por uma tradição. Tidas como obras fundadoras, as pesquisas e os textos elaborados por esses autores são influentes e permanecem como referências essenciais tanto para reflexões quanto para a ação envolvendo as mudanças políticas que ocorrem até hoje $\mathrm{e}^{13}$.

Feita a introdução específica ao capítulo, torna-se mais fácil examinar pormenorizadamente os elementos constitutivos e os rasgos principais dessa experiência intelectual.

\subsection{Os primeiros estudos sobre transições e seus cânones}

Durante os anos 1970 e 1980, profundas transformações ocorreram nos Estados do Sul da Europa e da América Latina. Diversos regimes autoritários, que há décadas governavam a maior parte dos Estados dessas duas regiões, deram sinais definitivos de crise e de esgotamento em um curto período, que não superou 15 anos. Essa vaga histórica foi aberta em 25 de abril de 1974, data da Revolução dos Cravos em Portugal, estendendose não apenas pela Europa mediterrânea, mas também cruzando o Atlântico ao irromper em diferentes países da América Latina.

13 Diversos estudiosos dedicados ao tema de democratização e da mudança entre regimes políticos reconheceram a importância e os méritos dessa primeira geração de cientistas políticos que desbravaram os campos da transitologia e da consolidologia, a despeito das diversas críticas que endereçam a essa tradição. Destaquem-se três opiniões significativas e exemplificativas do atual estado da arte dessas discussões. Avritzer considera que "a democratização consagrou as assim chamadas 'teorias da transição para a democracia' como a abordagem mais bem-sucedida acerca do problema”. AVRITZER, Leonardo. Cultura política, atores sociais e democratização: uma crítica às teorias da transição para a democracia. Revista Brasileira de Ciências Sociais, São Paulo, v. 10, n. 28, 1995. Disponível em: $<$ http://www.anpocs.org.br/portal/publicacoes/rbcs_00_28/rbcs28_09.htm>. Acesso em: 20 dez. 2011. Sergio Costa, por sua vez, assevera que "as chamadas teorias da transição democrática constituíram, sem dúvida, um dos filões mais profícuos da teoria social contemporânea nas duas últimas décadas, tendo reunido, em seu bojo, uma vasta gama de estudos e diagnósticos cuja qualidade acadêmica, vis-à-vis seus propósitos específicos, permanece inquestionada". COSTA, Sergio. Movimentos sociais, democratização e a construção de esferas públicas locais. Revista Brasileira de Ciências Sociais, São Paulo, v. 12, n. 35, out. 1997. Disponível em: $\quad<$ http://www.scielo.br/scielo.php?script=sci_arttext\&pid=S010269091997000300008\&lng=en\&nrm=iso>. Acesso em: $20 \mathrm{dez}$. 2011. Vitullo, por fim, enuncia que "a importante quantidade de livros, artigos e papers escritos sobre o tema tem dado lugar a essa nova subdisciplina que ganha cada vez maior espaço dentro da Ciência Política contemporânea". VITULLO, Gabriel Eduardo. VITULLO, Gabriel Eduardo. Transitologia, consolidologia e democracia na América Latina: uma revisão crítica. Revista de Sociologia e Política, Curitiba, n. 17, p. 53-60, nov. 2001. p. 53. 
A depender de fatores de diferentes ordens, cada um desses países atravessou uma experiência singular de mudança política, cuja intensidade e profundidade foram variáveis, condicionadas pelas realidades particulares.

Muitas foram as singularidades que caracterizaram cada um desses processos transicionais, desde revoluções e rupturas radicais até a transação de pactos político-sociais, passando pelo colapso abrupto de alguns dos regimes até então vigentes. Esse momento histórico constituiu uma comprovação privilegiada de que o poder está submetido às mais distintas inflexões em sociedades dinâmicas e complexas, sobretudo em tempos de excepcionalidade da política ${ }^{14}$. Um rico espectro de modalidades de mudanças ocorreu nesse curto período histórico.

Independentemente do tipo da mudança política operada, importantes traços comuns podem ser notados em meio a essa rica diversidade.

Em primeiro lugar, não há dúvidas de que a contemporaneidade desses acontecimentos, que se materializaram em um breve intervalo temporal, induziu a uma aproximação entre os rumos tomados por esses processos. Um horizonte de tempo recorta e limita as possíveis alternativas em um momento de transição política, conferindo-lhes certa identidade de época. Não à toa, tornar-se-á comum a referência a uma "terceira onda" da democratização, cujo epicentro estará justamente no Sul da Europa, na América Latina e na Europa do Leste, conforme descrição de Samuel Huntington.

Segundo esse autor, uma onda de democratização pode ser entendida como um grupo de transições de regimes não democráticos para democráticos, que ocorrem em um período de tempo específico e que significativamente são mais numerosas do que as transições na direção oposta durante tal período. Uma onda normalmente envolve também liberalização ou democratização parcial nos sistemas políticos que não se tornaram completamente democráticos, distinção importante para essa tradição, como se verá.

Huntington ainda sustenta o argumento de que foram três ondas de democratização no mundo moderno, com características próprias e alcances diversos. São elas: primeira onda longa de democratização (de 1828 a 1926), primeira onda reversa

14 Esquematicamente, podem-se diferenciar quatro alternativas: tomada do poder, transferência do poder, rendição do poder e derrubada do poder. MARTINS, Luciano. A "liberalização" do regime autoritário no Brasil. In: O’DONNELL, Guillermo; SCHMITTER, Philippe C.; WHITEHEAD, Laurence. Transições do regime autoritário: América Latina. São Paulo: Vértice; Revista dos Tribunais, 1988 [1986]. p. 113. 
(1922-42), segunda onda curta de democratização (1943-62), segunda onda reversa (195875), terceira onda de democratização (1974-). ${ }^{15}$

Isso não significa assumir um determinismo que retira a especificidade do campo político. Pelo contrário, como afirma Przeworski sobre essa "terceira onda" de redemocratizações, "o fato das transições recentes para a democracia terem ocorrido como uma onda também significa que elas aconteceram sob as mesmas condições políticas e ideológicas no mundo. Além do mais, o contágio desempenha um papel. Contemporaneidade induz a homogeneidade: as novas democracias aprendem com as já estabilizadas"16.

$\mathrm{Na}$ mesma linha, detalhando as diferentes explicações causais dessas ondas, Huntington considera improvável que a "concentração de transições em uma década e meia possa ter sido mera coincidência. Parece razoável supor que elas tenham sido produzidas, em parte, por causas comuns afetando muitos países, pelo desenvolvimento paralelo em vários países e pelo impacto de transições anteriores e posteriores"17.

Além disso, as proximidades geográficas e os cruzamentos históricos constantes implicaram semelhanças estruturais relevantes, que se manifestaram pelas características regionais assumidas tanto pelos regimes autoritários então em superação quanto pelas novas democracias que se estavam constituindo.

Precisamente a partir desses traços comuns é que se afirmou um objeto de investigação politológica com estatuto próprio, que permitiu uma análise comparada

15 HUNTINGTON, Samuel p. A terceira onda: a democratização no final do século XX. São Paulo: Ática, 1994. p. 23. Schmitter e Santiso, no entanto, postulam um modelo de interpretação das democratizações com quatro ondas. Baseiam-se em um critério mais restrito, segundo o qual a presença de uma onda exige um grau substancial de interação demonstrável e escolha interdependentes através das fronteiras nacionais em um período comprimido de tempo. Aplicando esse critério, desmembram a primeira onda descrita por Huntington (de 1848 a 1926) em duas menores: a primeira vai de 1848 até 1852 e a segunda, de 1914 a 1922 , acompanhando a Primeira Grande Guerra. Por sua vez, a terceira sucede a Segunda Grande Guerra e se encerra com a descolonização na África e na Ásia (1945 até meados da década de 1960. SCHMITTER, Phillippe C.; SANTISO, Javier. Three temporal dimensions to the consolidation of democracy. International Political Science Review, v. 19, n. 1, p. 69-92, 1998. p. 86. A quarta onda, ainda na descrição desses autores, é iniciada com a Revolução dos Cravos, em Portugal. Essa última onda tem características peculiares em relação às anteriores: “(1) foi muito mais global em seu alcance; (2) afetou muito mais países e foi mais radical em seu impacto regional; e, o mais importante, (3) sofreu proporcionalmente muito menos regressões para autocracia do que no passado". No original: (1) it has been much more global in its reach; (2) it has affected far more countries and been more thorough in its regional impact; and, most importantly, (3) it has suffered proportionally far fewer regressions to autocracy than in the past". SCHMITTER, Phillippe C.; SANTISO, Javier. Three temporal dimensions to the consolidation of democracy, p. 75.

16 No original: "the fact that recent transitions to democracy occurred as a wave also means that they happened under the same ideological and political conditions in the world. Moreover, contagion plays a role. Co-temporality induces homogeneity: The new democracies learn from the established ones". PRZEWORSKI, Adam. Democracy and market: political and economic reforms in Eastern Europe and Latin American. Cambridge: Cambridge University, 1991. p. 98 e 99.

17 HUNTINGTON, Samuel p. A terceira onda, p. 53. 
enfocada nas mudanças políticas ocorridas em cada um desses países. Os estudos pioneiros sobre as transições latino-americanas e sul-europeias inauguraram um capítulo de destaque na agenda de pesquisas das ciências sociais, cujas pretensões chegaram a uma sorte de teoria geral das transformações dos regimes políticos.

Cumpre notar que essa reflexão emerge em uma conjuntura marcada basicamente pelo ressurgimento dos regimes democráticos e, no plano internacional, pela distensão ideológica com o ocaso da Guerra Fria e o aprofundamento da mundialização dos mercados. Esse contexto servirá de estímulo para a emergência de uma extensa bibliografia analítica, que tematizará essas mudanças no âmbito da política como um objeto privilegiado, com vistas ao tratamento teórico e à formulação de políticas de institucionalização dos novos regimes.

Especial atenção, nessa perspectiva teórica, será conferida, inicialmente, aos processos conhecidos por transição e, em seguida, aos chamados de consolidação democrática.

É um traço marcante, nos textos que serão examinados, a tentativa de engendrar um modelo analítico capaz de dar conta de todos os processos transicionais e de consolidação democrática. Ainda que alguns poucos analistas já reconhecessem as dificuldades de elaborar uma teoria das transições por conta da falta de distanciamento histórico em relação ao objeto estudado ${ }^{18}$, o intuito era engendrar um referencial capaz de iluminar as diferentes situações, permitindo os estudos comparados que tanto animaram as primeiras reflexões em torno dessa questão.

Daí o texto-manifesto dessa tradição, prefaciado por Abraham Lowenthal, afirmar claramente a existência de certa previsibilidade, pois "as transições dos regimes autoritários são condicionadas e moldadas pelas circunstâncias históricas - peculiares em cada país, mas que seguem padrões previsíveis" ${ }^{19}$. Essa pretensão de universalidade, muitas vezes, acabou dando razão a uma crítica que será melhor explorada mais adiante, a qual considera problemáticas a "obstinada busca de generalizações e padrões comuns (...)

\footnotetext{
18 Por exemplo, o cientista político Luciano Martins: "devemos aceitar que ainda não existe um conjunto articulado de proposições passível de ser apresentado, de forma convincente, como uma 'teoria' da transformação ou do colapso dos regimes autoritários. De fato, não poderia ser de outra forma; em primeiro lugar, porque nos falta a perspectiva de tempo necessária à apreensão da tendência histórica subjacente tanto à emergência quanto ao declínio dos regimes autoritários contemporâneos". MARTINS, Luciano. A "liberalização" do regime autoritário no Brasil, p. 108.

19 LOWENTHAL, Abraham F. Prefácio. In: O’DONNELL, Guillermo; SCHMITTER, Philippe C. Transições do regime autoritário, p. 13.
} 
assim como a excessiva preocupação pela criação de tipologias e classificações onicompreensivas" 20 .

Esse instrumental teórico veio, de início, a serviço de uma análise empírica das transições políticas mais recentes e da afirmação das recém-instituídas democracias, especialmente aquelas ocorridas em um circuito inter-regional que compreende o Sul da Europa e a América Latina. No entanto, a partir do núcleo rígido da problemática da imprevisibilidade das mudanças políticas, firmou-se um ramo especializado do saber no âmbito da teoria social que terminou repercutindo com maior intensidade no campo da ciência política, constituindo dois campos particulares de reflexão conhecidos como transitologia e consolidologia ${ }^{21}$.

$\mathrm{Na}$ descrição precisa de dois cientistas políticos conhecedores do percurso dessas subdisciplinas:

\begin{abstract}
no curso dos últimos vinte anos, a literatura sobre a análise comparada dos processos de democratização produziu um repertório relativamente consensual para descrever, analisar, explicar e, de vez em quando, para prescrever as sequências e dinâmicas que conduzem à transformação dos regimes políticos. Não é exagero afirmar que esses esforços acabaram constituindo uma subdisciplina no seio das ciências políticas contemporâneas, os democratization studies - ou melhor, como nós pensamos, duas subdisciplinas independentes, embora interdependentes, sustentadas por fundações epistemológicas e orientações de pesquisa diferentes: a transitologia e a consolidologia ${ }^{22}$.
\end{abstract}

20 Daí a colocação de que, muitas vezes, essas análises impedem uma observação mais aguçada das singularidades de cada caso nacional e dificultam, também, uma melhor avaliação do tipo de democracia que ia se configurando. VITULLO, Gabriel Eduardo. Além da transitologia e da consolidologia: um estudo da democracia argentina realmente existente. Porto Alegre, 2005. 343 f. Tese (Doutorado em Ciência Política) - Universidade Federal do Rio Grande do Sul. p. 25. Também: VITULLO, Gabriel Eduardo. Transitologia, consolidologia e democracia na América Latina, p. 56.

21 Esses dois termos, que são utilizados por alguns dos próprios autores estudados, serão empregados neste trabalho com uma conotação crítica, mas sem qualquer teor irônico como se costuma interpretar. A primeira (transitologia) estaria dedicada essencialmente aos momentos iniciais da transição, ou seja, ao intervalo que marca a passagem entre dois regimes políticos. Por sua vez, a segunda (consolidologia), concebida sequencialmente à anterior, visaria ao fenômeno da estabilização dos procedimentos democráticos elementares e das instituições que os operacionalizam. Alguns vão além, abrangendo também no conceito de consolidação democrática preocupações como a densidade social e a legitimidade popular. VITULLO, Gabriel Eduardo. Transitologia, consolidologia e democracia na América Latina, p. 53-55. Análises posteriores continuarão usando essa terminologia: “(...) les domaines de recherche couverts par ce que nombre de spécialistes appellent désormais la "transitologie"”. DOBRY, Michel. Les transitions démocratiques regards sur l'état de la 'transitologie'. Revue Française de Science Politique, Paris, v. 50, n. 45, p. 615-631, ago./out. 2000. p. 579.

${ }^{22}$ No original: "au cours des vingt dernières années, la littérature sur l'analyse comparée des processus de démocratisation a produit un éventuail relativement consensuel décrire, d'analyser, d'expliquer et, à l'occasion, de prescrire les séquences et les dynamiques conduisant à la transformation des régimes politiques. Il n'est pas exagéré d'affirmer que ces efforts ont fini par constituer une sous-discipline distincte au sein des sciences politiques contemporaines, les democratization studies - ou mieux, comme nous le pensons, deux sous-disciplines indépendantes bien que solidaires, sous-tendues par des fondations épistémologiques et des orientations de recherche fort diferentes: la 'transitologie' et la 'consolidologie"'. GUILHOT, Nicolas; SCMITTER, Philippe C. De la transition à la consolidation: une lecture rétrospective des democratization studies. Revue Française de Science Politique, v. 50, n. 4-5, p. 615-631, ago./out. 2000. p. 615 . 
Essas ditas subdisciplinas acabaram sendo mobilizadas para análises de mudanças em regimes políticos em diferentes lugares do mundo, tais como as transições póssoviéticas, ocorridas na Europa do Leste. No entanto, a despeito dessa reflexão ter transcendido posteriormente as regiões geográficas que delimitaram os estudos empíricos inicialmente realizados, pelo grau de abstração que esses modelos analíticos pretendem encerrar, nessa pesquisa, será priorizada a literatura relativa às transições operadas nas ditaduras latino-americanas. Isso porque as transformações dos regimes políticos "burocrático-autoritários" ${ }^{23}$ foram, inquestionavelmente, o foco privilegiado desses autores naquele período, inclusive pelos importantes vínculos pessoais e acadêmicos que mantinham com esses países.

\subsection{O que define uma transição: a incerteza constitutiva}

Como foi observado, o foco as análises, inicialmente, recaiu sobre as mudanças entre regimes políticos, algo que se convencionou designar por transição. Em paralelo, emergiu outra reflexão, que será trabalhada mais adiante, em torno da institucionalização de novas democracias após a transição de regimes autoritários, materializada no conceito de consolidação. Ainda que não se tratassem de termos estranhos ao vocabulário da ciência política, somente a partir dos anos 1980 foi que as expressões 'transição' e 'consolidação' passaram a ser amplamente utilizadas nos trabalhos acadêmicos, nas mídias, nos discursos oficiais e nas políticas públicas ${ }^{24}$.

23 Retoma-se, aqui, o conceito de Estado burocrático-autoritário ("BA") elaborado e consagrado por Guillermo O’Donnell. Segundo esse autor, era preciso analisar as peculiaridades das novas formas de dominação autoritária que emergiram na América Latina a partir do golpe de Estado de 1964 no Brasil, continuaram com o golpe na Argentina em 1966 e, na década de 70, assumiram no Chile, no Uruguai e novamente na Argentina características muito agudas. De acordo com sua definição, o BA é espécie do gênero Estado capitalista, que possui as seguintes características: 1) sua principal base social é a grande burguesia; 2) institucionalmente, é um conjunto de organizações no qual adquirem peso decisivo aquelas especializadas na coerção, bem como as que tentam levar a cabo a "normalização" da economia; 3 ) é um sistema de exclusão política de um setor popular previamente ativado; 4) tal exclusão provoca a supressão da cidadania e da democracia política; 5) também é um sistema de exclusão econômica do setor popular; 6) tenta sistematicamente "despolitizar" o tratamento de questões sociais; 7) seu regime, não formalizado porém claramente vigente, implica o fechamento dos canais democráticos de acesso ao governo e, junto com eles, dos critérios de representação popular ou de classe. O’DONNELL, Guillermo. Análise do autoritarismo burocrático. Rio de Janeiro: Paz e Terra, 1990. p. 19, 61 e 62.

24 No sentido desse argumento, é curioso notar que o clássico "Dicionário de Política", a despeito das limitações e lacunas inerentes a esse tipo de trabalho, não inclui verbete algum que se aproxime aos conceitos de 'transição' e 'consolidação' como tais. Obviamente, ideias de mudança política e de democratização 
Conforme o senso comum, as transições ocorreriam de forma instantânea, como resposta ao desejo e até mesmo à idealização do modo pelo qual as mudanças sociais e políticas deveriam ocorrer. Transições políticas, sob tal perspectiva, seriam espécie de atos únicos, consumados em um só momento.

No entanto, o olhar empírico direcionado por esses autores às experiências transicionais de diversos tempos e espaços sugere que, embora as tarefas e questões mais prementes das transformações sociais imponham-se de imediato a um novo governo, nos momentos posteriores à sua investidura é que costumam ser enfrentadas as questões mais candentes da transição, por isto mesmo negligenciadas e delegadas para a posteridade. Em outras palavras, sob essa perspectiva, a aurora de um novo regime normalmente não é mais do que um prefácio, tendo em vista que as transições não têm prazo definido ou um rol de tarefas predeterminadas a cumprir, ainda que sempre motivadas e impulsionadas pela pressa e pelas reivindicações dos diferentes atores políticos.

A noção de transição gradual e processual, embora se admitam exceções de rupturas mais imediatas e profundas, explica a regra das transformações políticas mais recentes desses países analisados pelos transitólogos. Isso porque uma das características mais universalizáveis das diferentes ordens sociais é sua tendência à estabilização e ao isolamento, em uma busca constante de demarcar suas fronteiras e, assim, afirmar suas próprias identidades.

Em uma definição mais abstrata e geral, evidentemente inspirada em dicionário e pouco técnica, a transição de um tipo de regime implica no movimento de uma coisa para outra $^{25}$. Compreende, assim, a mudança de um algo para outro algo. De forma mais concreta, mas ainda sob um prisma minimalista e objetivo, comumente adotado por essa tradição de pensadores, pode ser entendida como o intervalo de tempo entre a crise de um regime político anterior e a afirmação de um novo, uma definição de caráter temporal ou cronológica. Supõe-se que, em cada um dos dois extremos desse interregno de tempo, encontra-se um regime político razoavelmente estabilizado.

Nessa linha, um dos mais reconhecidos teóricos dessa tradição, Guillermo O’Donnell, no capítulo introdutório da referida obra fundadora que assenta seus pressupostos gerais, intitulado "Definindo alguns conceitos e expondo certas premissas", “o termo 'transição' consiste no intervalo entre um regime político e outro. As transições

encontram-se contempladas em outros verbetes dessa obra, mas sem as características de um campo de reflexão e um corpo teórico relativamente autonomizado. Cf. BOBBIO, Norberto; MATTEUCCI, Nicola; PASQUINO, Gianfranco (Org.). Dicionário de Política. Brasília: UnB, 1986 [1983].

${ }_{25}$ O’DONNELL, Guillermo; SCHMITTER, Philippe C. Transições do regime autoritário, p. 107. 
se delimitam, de um lado, pelo início do processo de dissolução de um regime autoritário e, de outro, pela investidura de alguma forma de democracia, pelo retorno a algum tipo de regime autoritário ou pela emergência de um regime revolucionário" ${ }^{26}$. Nesse mesmo sentido, apenas em outras palavras, outro dos autores define a transição como "o lapso de tempo que decorre entre a liquidação de um regime autoritário e a institucionalização de um outro regime - qualquer que ele venha a ser"${ }^{, 27}$.

Desse modo, entende-se a transição política como um momento histórico em aberto, marcado por um processo complexo e não linear, em que diversas forças sociais concorrem por imprimir um destino comum à coletividade. Nesse processo, inexiste uma escala de estágios ou pontos de passagem definidos de antemão.

Essa é a definição canônica da transição. Refletir sobre essa categoria de mudanças políticas tem, por premissa que decorre da própria definição do conceito, examinar quais seus pontos de partida e de chegada: um "a partir de que" e seu correspondente "para onde". Sob a ótica considerada, concebida como um intervalo temporal, a transição seria precisamente uma passagem, uma ponte entre dois regimes diferentes entre si, atravessada em um determinado período de tempo. Se o ponto de partida é sempre um dado conhecido, por outro lado, o destino e a duração da mudança apresentam-se como dados inevitavelmente incertos, indefiníveis a priori, diante da multiplicidade de desfechos do jogo político ${ }^{28}$.

Talvez a principal razão que explica a indeterminação tanto do resultado quanto da duração de uma transição remete ao inevitável desencontro entre os fatores que motivaram o fim do regime anterior e os fatores responsáveis pela afirmação de uma nova ordem política. Em outras palavras, é bastante comum nesse tipo de situação que "os fatores que foram necessários e suficientes para provocar o colapso ou autotransformação do regime autoritário não serem necessários e suficientes para assegurar a instauração de outro regime - e, menos que tudo, de uma democracia política"29. Soma-se a isso o fato da legitimidade do sistema político estar em compasso de renovação, voltada para uma

26 O’DONNELL, Guillermo; SCHMITTER, Philippe C. Transições do regime autoritário, p. 22. Em outros termos, é o caminho que leva do autoritarismo à sua negação, preferencialmente à democracia como se verá. 27 MARTINS, Luciano. Ação política e governabilidade na transição brasileira. In: MOISÉS, José Álvaro; ALBUQUERQUE, José A. Guilhon (Org.). Dilemas da consolidação da democracia. Rio de Janeiro: Paz e Terra, 1989. p. 225.

28 Essa dificuldade de se definir os marcos no interior dos quais se desdobra um processo de transição é mais manifestamente de ordem objetiva, pois, subjetivamente, "quem já viveu sob uma ditadura ou um regime autoritário não tem dúvidas, quando a opressão termina, de que efetivamente mudanças ocorreram". PINHEIRO, Paulo Sérgio. Autoritarismo e transição. Revista da USP, São Paulo, n. 9, p. 45-56, mar./maio 1991. p. 46.

29 O’DONNELL, Guillermo; SCHMITTER, Philippe C. Transições do regime autoritário, p. 107. 
redefinição futura em disputa no presente, pois as regras do passado precariamente vigentes não mais contam com a aceitação social e a adesão plenas no âmbito da comunidade política.

Baseado na referida constatação, Schmmiter chega até mesmo a ressalvar criticamente a expressão "transição" por entender que carrega, em si mesmo, a ideia de que o resultado da mudança seria predeterminado e, portanto, já conhecido ${ }^{30}$. E, certamente, não era esse o caso das mudanças de ordem política de desfecho imprevisível, ainda mais dos casos empíricos que servem de base para esses autores.

Essa visão básica é compartilhada pelos diversos estudiosos mencionados. Ainda que se dediquem prioritariamente à transição de regimes autoritários para sistemas democráticos, isso ocorre por mera contingência, afinal, nesse sentido, predominantemente, ocorreram as mudanças políticas nos países afetados pela "terceira onda". Por isso, destacam que "nos países por nós considerados, a coisa inicial foi (ou ainda o é) o regime autoritário (...). A alguma outra coisa subsequente, em geral, é a democracia política”31.

De modo geral, dado a pretensão de universalidade que essa reflexão carrega, a democracia é apenas uma das possibilidades. Nas palavras de Guillermo O’Donnell, “a democracia política é só um desembocamento possível. O essencial é advertir que, entre as muitas questões que estão em jogo na transição, inclui-se a construção de um novo regime político" ${ }^{, 32}$.

A abertura completa em relação aos resultados só vai se definindo a partir dos projetos e estratégias de que os atores políticos relevantes são portadores. Basicamente destes dependerá o desfecho dessas conjunturas críticas e dramáticas. Por isso a colocação categórica de Przeworski, para quem a "auto-aplicação da democracia não é o único desenlace possível das transições: situações estratégicas que surgem quando uma ditadura sucumbe. A democracia consolidada é apenas um dentre os possíveis resultados do colapso de um regime autoritário”33. Daí demandar-se, para uma solução específica nesse sentido, uma "estratégia clara de construção da democracia e dos atores que se identificam como portadores da proposta democrática" ${ }^{34}$.

\footnotetext{
30 No original: "The term 'transitions' is not very fortunate label for these situations, since it suggests that the outcome is predetermined". PRZEWORSKI, Adam. Democracy and Market, p. 37.

31 O’DONNELL, Guillermo; SCHMITTER, Philippe C. Transições do regime autoritário, p. 107.

32 O'DONNELL, Guillermo. Contrapontos: autoritarismo e democratização. São Paulo: Vértice; Revista dos Tribunais, 1986. p. 81.

33 No original: "Self-enforcing democracy is not the only possible outcome of 'transitions': strategic situations that arise when a dictatorship collapses (...). Consolidated democracy is only one among the possible outcomes of the collapse of authoritarian regimes”. PRZEWORSKI, Adam. Democracy and Market, p. 37.

34 MOISÉS, José Álvaro; ALBUQUERQUE, José A. Guilhon. Apresentação. In: Dilemas da consolidação da democracia, p. 13. (Org.).
} 
Em suma, o lapso entre o desaparecimento progressivo de uma forma de governo e o surgimento de outra não pode ser previamente definido, o que engendra sua ontológica imprecisão. Assim, se é característico da política $^{35}$ e, especialmente, da democracia uma indefinição permanente quanto aos resultados das interações de poder ${ }^{36}$, durante as transições, essa incerteza é potencializada a um extremo, que se realiza, idealmente, na crença radical na capacidade criativa e inventiva da ação política. Daí a consideração de Francisco Weffort de que o processo da transição é, por sua qualidade e por suas próprias características, povoado de incertezas ${ }^{37}$.

\subsection{O excepcionalismo metodológico}

Sem dúvidas, a incerteza é a marca própria mais característica da transição, o traço que lhe confere sua mais notória singularidade. Se conhecer é diferenciar, a incerteza é o que confere estatuto próprio e identificável a um processo transicional.

Todos os estudiosos que posteriormente se debruçaram sobre a literatura examinada têm pleno acordo em relação a esse aspecto. Imbuídos de um espírito otimista quanto à "invenção democrática", que deve ser contextualizado diante da crise desses regimes autoritários e da promessa de um futuro das mudanças que embalou a ciência política na passagem dos anos 1980 para os 1990, esses autores privilegiavam um olhar destinado a capturar o que reputavam como a "extraordinária incerteza da transição"38.

35 Diversos teóricos têm trabalhado com compreensões da política pela via da indeterminação, ainda que sob perspectivas bastantes diversas entre si. Por exemplo, em estudo específico dedicado à relação entre a política e a incerteza, Cioffi-Revilla considera que "a causa fundamental da incerteza da política repousa sobre a natureza indeterminável dos atos decisionais dos indivíduos e dos estados de natureza (loterias) que estão frequentemente além do controle dos atores políticos, grupos e estados". No original: "the fundamental cause of uncertainty of politics lies in the indeterminate nature of individual decisional acts and states of nature (lotteries) that are most commonly beyond the control of political actors, groups, or states". CIOFFIREVILLA, Claudio. Politics and uncertainty: theory, models and applications. Cambridge: Cambridge University, 1998. p. 5.

$36 \mathrm{Na}$ definição já clássica de Przeworski, "a democracia é um sistema de incompletude regulada, ou incerteza organizada. A incerteza inerente à democracia permite a ação instrumental (...). Se os resultados fossem ou predeterminados ou completamente indeterminados, não haveria razão para os grupos se organizarem como participantes". No original: "Democracy is a system of ruled open-endedness, or organized uncertainty. The uncertainty inherent in democracy does permit instrumental action (...). If were either predeterminned or completely indeterminate, there would be no reason for groups to organize as participants". PRZEWORSKI, Adam. Democracy and Market, p. 13.

37 WEFFORT, Francisco. Incertezas da transição na América Latina. In: MOISÉS, José Álvaro; ALBUQUERQUE, José A. Guilhon (Org.). Dilemas da consolidação da democracia, p. 69.

38 O’DONNELL, Guillermo; SCHMITTER, Philippe C. Transições do regime autoritário, p. 18. 
Conforme anunciam no texto que pode ser considerado como o manifesto fundador da tradição, "poucos momentos trazem consigo, como este o faz, escolhas e responsabilidades tão angustiantes, tanto no campo ético, quanto no político"39. Daí a necessidade que postulam de que sejam incluídos, nas análises, os seguintes fatores:

elementos de acidentalidade e imprevisibilidade, de decisões essenciais tomadas às pressas, com base em informações bastantes inadequadas, de atores enfrentando dilemas éticos e confusões ideológicas sem solução, de momentos decisivos dramáticos alcançados e ultrapassados sem uma compreensão do seu futuro significado ${ }^{40}$.

Há um discurso que leva bastante a sério a exceção vivida nesses momentos históricos. A inescapável contingência quanto ao futuro tem consequências diretas e profundas na reflexão da primeira geração de transitólogos. A mais expressiva delas é a adoção, pelos autores tratados, de um excepcionalismo metodológico bastante marcante ${ }^{41}$. Anômalos, os processos de transição seriam, por definição, distintos da consolidação democrática e do funcionamento ordinário dos regimes políticos, razão por si só, suficiente para sustentar-se que os métodos e as explicações convencionais não podem ser aplicados nos mesmos termos.

De tão acentuada, a indefinição espantosamente extremada, se durasse muito tempo, poderia chegar a um ápice, que se manifestaria como a impressão até mesmo de uma desordem no plano da política. Não por outro motivo, O’Donnell afirma que "é característico de uma transição o fato de, durante o tempo do seu transcurso, as regras do jogo político não se verem definidas" ${ }^{42}$. Daí, inclusive, o papel menor das regras e instituições, que saem temporariamente de cena e permitem que os atores políticos coloquem em prática, com assombrosa margem de ação e de liberdade, suas estratégias e vontades.

39 O’DONNELL, Guillermo; SCHMITTER, Philippe C. Transições do regime autoritário, p. 18.

40 O'DONNELL, Guillermo; SCHMITTER, Philippe C. Transições do regime autoritário, p. 18. Esse estado de espírito peculiar, que conjuga os sentimentos contraditórios de dúvida extrema quanto ao destino da mudança e, ao mesmo tempo, de crença sobrenatural na força de determinação da política, foi bem captado por Przeworski. Ele afirmou que "qualquer um que tenha vivido os momentos que precedem a queda de uma ditadura, quando a democracia torna-se uma possibilidade real, há de lembrar a tensão quase constante, a alternância de esperanças e medos, os acessos de entusiasmo e a dor das frustrações. Cada etapa apresenta-se frágil e ainda assim nada parece inatingível". PRZEWORSKI, Adam. Amas a incerteza e serás democrático. Novos Estudos CEBRAP, São Paulo, n. 9, p. 36-46, jul. 1984. p. 36.

41 Referindo a esse importante ponto, Vitullo declara que "a nova corrente alega a necessidade de um excepcionalismo metodológico, o que configura outro de seus elementos caracterizadores. Os autores que aderem ao novo paradigma justificam-no pelo excepcional das próprias situações sob estudo; consideram que as ciências sociais normais têm sido pensadas para períodos de estabilidade política e, consequentemente, não serviriam para analisar mudanças de regime, transições ou períodos de crises agudas”. VITULLO, Gabriel Eduardo. Transitologia, consolidologia e democracia na América Latina, p. 54.

42 O'DONNELL, Guillermo; SCHMITTER, Philippe C. Transições do regime autoritário, p. 22. 
Dessa argumentação mais geral, baseada na suposição de que a transição se caracteriza por uma indefinição constitutiva do próprio conceito, é possível extrair três consequências importantes para esse tipo de abordagem teórica, que serão aprofundadas uma a uma a seguir.

A primeira é a de que as linhas determinantes de força de um processo transicional não estão atreladas, fundamentalmente, a condicionantes de ordem estrutural. Por sua vez, podendo ser compreendida como uma decorrência do papel menor e até mesmo desprezível reservado às estruturas no processo transicional, a segunda consequência é a de que o que realmente importa, nos momentos de excepcionalidade, é o jogo político travado dentro das fronteiras nacionais e com especial destaque não para as regras que o balizam, mas para a ação e a interação dos diversos atores considerados relevantes. Por último e não menos importante, como terceira consequência, as análises supõem uma tarefa premente que deve ser buscada como uma espécie de urgência do processo transicional. Pode-se afirmar que esta última é uma das principais, para não dizer a única dimensão normativa importante que carregam, haja vista a aversão que apresentam normalmente em relação a questões substantivas.

Trata-se, em suma, do objetivo de estabelecer regras e procedimentos institucionais capazes de estabilizar o mais rápido possível uma nova ordem, sob pena de perpetuar uma situação insuportável de incerteza que pode minar, na concorrência política irrefreada, os laços coletivos de convivência. Ou seja, é a imperatividade de "assegurar, no imediato, condições de governabilidade durante a transição" ${ }^{43}$, o que determina e limita a agenda política que poderá ser discutida e concretizada, inclusive as demandas por justiça, questão importante para a presente pesquisa.

\subsubsection{Suspensão das estruturas e os limites nacionais nas transições}

Para os autores, as transições são impulsionadas e solucionadas, predominantemente, dentro dos limites dos territórios nacionais. Essa compreensão remete, inevitavelmente, a uma constatação antiga, que vai na linha do reconhecimento do EstadoNação como o epicentro da política nas sociedades modernas. Daí a atenção especial aos

43 MARTINS, Luciano. Ação política e governabilidade na transição brasileira, p. 228. 
processos de negociação e conflito travados entre os diversos atores políticos interessados em ocupar os postos de poder.

Nessa linha, assumindo o otimismo do momento histórico que vivem no que concerne à imensa força criadora da política, essa tradição afirma persistentemente que "as razões para deslanchar uma transição residem, predominantemente, em fatores domésticos, internos" 44 ou, em outras palavras, que "os fatores domésticos desempenham um papel predominante na transição",45.

Associada ao recorte nacional da política moderna, bastante difundido e pouco questionado mesmo em tempos de aprofundamento da globalização, terá destaque a consideração de que o papel protagônico dos atores políticos sobrepuja os condicionantes de quaisquer ordens, prevalecendo e assumindo maior destaque no resultado final. Para valer-se de terminologia cara à teoria sociológica, na perspectiva dos pensadores analisados, os sujeitos e suas vontades impõem-se às estruturas e são, efetivamente, a força motriz do processo de transformação política.

Nesse sentido, a assertiva comum a esses autores, bastante elucidativa da perspectiva deles, é a de que "o que os atores fazem e não fazem parece muito menos decisivamente determinado por fatores 'macroestruturais' durante as transições (...)". É essa característica, inclusive, que contribuiria de forma significativa para que os processos políticos sejam abertos quanto a seus fins, por serem imprevisíveis as condutas dos atores, além de repletos de contradições, elementos fundamentais da indefinição mencionada acima.

É justamente a incerteza que anima os jogadores a engajarem-se na política, movidos pela expectativa de que seu comportamento é capaz de gerar resultados concretos e palpáveis, dissolvendo as grandes causalidades nas ações racionais e contingentes dos atores. Nesse sentido, no posicionamento de Przeworski, a "democracia gera a aparência de incerteza porque é um sistema de ação estratégica descentralizada na qual o conhecimento é inescapavelmente local» ${ }^{46}$.

Assentada essa premissa, caberá, então, analisar, em cada experiência ou contexto transicional, quais as necessidades e demandas em jogo, qual a densa trama de expectativas desenhada, quem são os atores políticos e sociais a protagonizar os processos, de que

44 O’DONNELL, Guillermo; SCHMITTER, Philippe C. Transições do regime autoritário, p. 39.

45 O'DONNELL, Guillermo; SCHMITTER, Philippe C. Transições do regime autoritário, p. 41.

46 No original: “(...) democracy generates the appearance of incertainty because it is a system of decentralized strategic action in which knowledge is inescapably local”. PRZEWORSKI, Adam. Democracy and Market, p. 12. 
projetos são portadores, quais tarefas se atribuem e de que forma mobilizam os recursos necessários para desencadear as profundas mudanças políticas e sociais em questão.

Contudo, é importante destacar que a perspectiva ora tratada não significa, necessariamente e por si só, uma negação completa da existência de determinações de ordem estrutural nas questões políticas contemporâneas. Pelo contrário, estas são até mesmo reconhecidas na ótica da oposição entre sujeito e estrutura adotada por esses autores. O que insistem em frisar é o papel menor, muitas vezes até mesmo desprezível, dos condicionantes diante da especificidade dos processos transicionais. Isso porque a causalidade estrutural não consegue competir com as outras causalidades tipicamente políticas nesses momentos peculiares ${ }^{47}$.

Nota-se com frequência na literatura analisada, uma oscilação da forma como e em qual medida as determinações de ordem estrutural são consideradas. Diversas matizes costumam aparecer nas análises concretas, mas dentro de certos parâmetros facilmente identificáveis. Nessa linha, a impressão geral e incontestável decorrente desses escritos é, justamente, que esses autores fazem uma opção consciente pela renúncia aos fatores estruturais, não porque os ignorem, mas simplesmente porque entendem acertada essa opção diante da particularidade do momento transicional.

Como afirma O’Donnell, “a dinâmica da transição de um regime autoritário não se resume a meras disposições, cálculos ou pactos das lideranças. A ênfase atribuída a alguns destes aspectos no decorrer deste trabalho deve-se à consideração de que sejam fortemente determinantes para a ocorrência ou não da abertura; igualmente fixam importantes parâmetros para a extensão da liberalização a uma eventual democratização"48.

Nesse aspecto, vale lembrar que a reflexão dos autores mencionados surge até mesmo como uma reação ao estruturalismo que predominou no debate acadêmico durante boa parte do séc. XX e, sobretudo, nas análises do advento do autoritarismo e nas teorias da modernização. Visão esta, aliás, que chegou a ser partilhada por alguns deles, destacando-se o caso de O'Donnell.

A postura teórico-metodológica estruturalista apontava a debilidade das burguesias nacionais, a pobre estruturação das classes sociais, o predomínio de uma cultura

\footnotetext{
47 Lembra Luciano Martins que as análises feitas situam-se "no plano estrito da ação política", o que não significa "desconsiderar que o desempenho dos atores face a essas tarefas da transição está sujeito a condicionantes e constrangimentos objetivos (de natureza econômica, ou de outras naturezas) de maior ou menos importância e gravidade". MARTINS, Luciano. Ação política e governabilidade na transição brasileira, p. 230.

48 O’DONNELL, Guillermo; SCHMITTER, Philippe C. Transições do regime autoritário, p. 83.
} 
política autoritária e a dependência dos grandes centros econômicos internacionais como fatores responsáveis pela ruptura dos regimes democráticos no passado. ${ }^{49}$

Nessa linha, em interessante estudo sobre a primeira geração da transitologia, o cientista político José Álvaro Moisés destaca que a orientação teórica desses autores, desejando corretamente superar o determinismo típico das teorias de modernização e de desenvolvimento político dos anos 50 e $60^{50}$, concentrou parte substancial da sua reflexão sobre o efeito das 'incertezas' nas situações de 'interação estratégica', permitindo o protagonismo dos atores, suas estratégias, cálculos e interações ${ }^{51}$.

Já a nova vertente se oporia a isso, filiando-se a uma espécie de individualismo metodológico, ao dedicar-se ao papel das elites políticas, priorizando suas decisões, ações e estratégias, tanto de embates quanto de conciliação. A macroanálise das estruturas é substituída, então, por uma perspectiva microanalítica dos sujeitos, suas motivações e mobilizações. Interessam, nos momentos excepcionais, menos os problemas econômicosociais, mas, antes, de maneira mais pungente, o jogo do poder político.

Levando a sério o excepcionalismo metodológico já mencionado, esses autores radicalizam a ideia de que as explicações estruturais e funcionalistas tradicionais, com seus repertórios conceituais e lógicas próprias deveriam ficar em suspenso e ceder seu lugar a outro tipo de instrumentos conceituais mais adequados para estas novas realidades ${ }^{52}$. Afinal, precisamente o que daria um "sabor especial a muitos momentos da transição" é "o sentimento exultante (mesmo que resulte exagerado) de que o futuro está aberto e de que os ideais e decisões contam tanto quanto os interesses e estruturas",53.

\footnotetext{
49 VITULLO, Gabriel Eduardo. Além da transitologia e da consolidologia, p. 17.

50 As teorias da modernização compreendiam, de forma geral, que a democratização dependia de fatores exógenos, especialmente as tendências socioeconômicas, postas como pré-condições funcionais para determinar a natureza e o funcionamento de um regime político. Isso porque os recursos de poder estariam distribuídos conforme o grau de diferenciação social e de desenvolvimento econômico correspondente. Desse modo, interessam, nessa perspectiva, critérios tais como número de habitantes, capital acumulado, industrialização, urbanização e educação, para recuperar apenas Seymour M. Lipset, um dos mais notórios representantes dessa teoria. Esses elementos influem no comportamento dos agentes sociais e, em última instância, alimentam as características do próprio sistema político. Consideram, assim, "as mudanças de regimes como a formalização política de transformações sociais precedentes”. No original, “... elles considèrent les changements de régime comme la formalisation politique de transformations sociales precedentes" GUILHOT, Nicolas; SCMITTER, Philippe C. De la transition à la consolidation, p. 617.

51 MOISÉS, José Álvaro. Entre a "incerteza" e a tradição política: uma crítica da primeira geração de estudos da transição. Novos Estudos CEBRAP, São Paulo, n. 40, p. 88-100, nov. 1994. p. 89. Nessa linha, Dobry descreve que "nos últimos quinze anos, a análise dos processos de democratização foi fortemente inclinado de perspectivas deterministas ou estruturalistas para a apreensão das transições em termos de cálculos, escolhas racionais ou saber-fazer (know-how) dos atores políticos". No original: "depuis une quinzaine d'anées, l'analyse des processos de démocratisation avait massivement basculé de perspectives déterministes ou 'structurelles' vers l'appréhension des trasitions en termes de calculs, choix rationnels ou savoir-faire des acteurs politiques". DOBRY, Michel. Les transitions démocratiques regards sur l'état de la 'transitologie', p. 581.

52 VITULLO, Gabriel Eduardo. Além da transitologia e da consolidologia, p. 19.

53 O’DONNELL, Guillermo; SCHMITTER, Philippe C. Transições do regime autoritário, p. 41.
} 
Uma crítica interessante a essa postura metodológica, acompanhada de um estudo do caso brasileiro, encontra-se na tese de livre docência do sociólogo Brasílio Sallum Jr, defendida na Universidade de São Paulo. Ele entende que a situação de transição não aumenta tanto a indeterminação na vida social a ponto de justificar a opção pelo individualismo metodológico ${ }^{54}$.

Esse autor sustenta que a linha-mestra dos estudos clássicos sobre a democratização oscila entre dois polos, que seriam apenas duas manifestações da perspectiva "politicista" dessa tradição ${ }^{55}$. Em um deles, predominam as noções de sistema, regime e instituições políticas e, no outro polo, prevalecem as referências a atores que enfrentam dilemas e escolhem racionalmente ${ }^{56}$. É possível acrescentar que, sem dúvida, esta última prevalece nas análises da transitologia tendo em vista uma suspensão temporária das regras, objeto de reinvenção nesses momentos; a primeira perspectiva, por sua vez, prevalece no campo da consolidologia.

Ainda segundo Sallum Jr., o fato do mainstream das análises políticas das transições terem se concentrado em demasia nos aspectos político-institucionais da mudança é produto de uma operação analítica que exclui a presença estrutural da economia e da sociedade na esfera política. Daí esses autores investigarem a transição como se os processos políticos fossem, para efeitos analíticos, completamente autônomos ${ }^{57}$.

54 SALLUM JÚNIOR, Brasilio. Labirintos: dos generais à Nova República. São Paulo, 1996. Tese (LivreDocência em Sociologia) - Faculdade de Filosofia, Letras e Ciências Humanas, Universidade de São Paulo. Essa relação íntima entre a incerteza inerente à democracia e a racionalidade (imperfeita e possível diante da situação transicional) dos atores individuais é bem explorada por Javier Santiso. Esse autor alega que "cette conception de la démocratie incertaine est au coeur des analyses faites sur l'Amerique latine en termes de choix rationnels". SANTISO, Javier. La démocratie incertaine: la théorie des choix rationnels et la démocratisation en Amérique latine. Revue Française de Science Politique, Paris, v. 43, n. 6, p. 970-993, dez. 1993. p. 980.

55 Outra crítica pertinente é a que considera que as explicações politicistas, ao formalizarem e simplificarem de maneira exagerada, não têm deixado lugar suficiente para a história de cada país e suas particularidades culturais.

56 Essa distinção entre aspectos normativo-procedimentais e atitudinais na compreensão da política para discutir a natureza dos regimes políticos e seus graus de institucionalização estão exploradas de maneira instigante em GUILHOT, Nicolas; SCMITTER, Philippe C. De la transition à la consolidation, p. 616 e 617. 57 SALLUM JÚNIOR, Brasilio. Labirintos. Na contramão, nesse trabalho, Sallum Jr. proclama tanto o peso das estruturas na explicação das práticas como a presença estrutural - que, portanto, só cabe abstrair provisoriamente - da base socioeconômica na esfera política. Vale registrar, contudo, que esses autores pertencentes à transitologia não aceitam essa qualificação passivamente. Argumentam que "não são inocentemente politicistas", pois "não acreditam que a política tenha determinações autônomas de outros campos da vida social, nem que estes possam ser reduzidos à primeira”. O’DONNELL, Guillermo. Prefácio. In: MOISÉS, José Álvaro; ALBUQUERQUE, José A. Guilhon (Org.). Dilemas da consolidação da democracia, p. 9. No entanto, concretamente, a despeito da retórica mais flexível e tolerante às demais causalidades, as análises pioneiras desses autores ignoram solenemente tudo o que não for atinente à vontade política dos atores estratégicos, afastando a contribuição de outros modelos interpretativos. Daí a precisa ponderação de Branco, "pois se os principais autores desta linha interpretativa sempre deixaram claro que ao adotarem tal método não estavam desconsiderando a pertinência da história particular de cada país e sua situação econômica, bem como o papel da sociedade no processo de mudança, o fato é que esta 
A autonomização, que não raro resvala para um tipo de autonomismo, será duramente criticada. Ao colocar em relevo a dimensão subjetiva da política, para resgatá-la do peso sufocante das estruturas, incorre-se no risco de uma análise voluntarista que concede um lugar preponderante à noção de "habilidade política" e que é tributária de uma certa "ilusão heróica" 58 . Não por acaso, como se verá mais adiante, alguns dos autores chegam a prescrever "guias de ação aos democratizadores", espécie de receitas de condutas e orientações para consolidar a boa democracia, como se tudo dependesse, em última instância, de um convencimento dos atores estratégicos.

Esclarecida a tese da insólita autonomia da política nos momentos da mudança, que os transitólogos postulam, em contraposição às causalidades de ordem estrutural (econômica, social, cultural e até política em sentido lato), é conveniente examinar agora as articulações internas do campo político e dos jogos de poder, a fim de compreender as linhas de força que determinam a dinâmica dos processos transicionais.

\subsubsection{O jogo das elites políticas: escolha racional e institucionalismo estratégico}

Um dos consensos fundamentais que confere um traço de unidade para as análises dos distintos autores que estamos tratando é a compreensão da mudança política a partir dos atores estratégicos envolvidos. Mas não são quaisquer atores que importam efetivamente. A transitologia está interessada, sobretudo, na ação das lideranças políticas, excluindo outros sujeitos sociais e históricos ${ }^{59}$.

autonomização político-institucional inibiu outros caminhos de interpretação, passando a valer como o mainstream do assunto". BRANCO, Marcello Simão. Da transição dos anos 80 para o início do século XXI: uma discussão teórica e comparativa da democratização na América Latina. São Paulo, 2002. Dissertação (Mestrado em Ciência Política) - Faculdade de Filosofia, Letras e Ciências Humanas, Universidade de São Paulo. p. 27.

58 No original: “(...) analyses volontaristes qui accordent une place prépondérante à la notion 'd'habileté politique', et qui restent tributaire d'une certaine 'illusion héroique". SANTISO, Javier. La démocratie incertaine, p. 990 e 991.

59 Essa perspectiva veicula um modelo interpretativo que considera as elites em detrimento da sociedade, as dinâmicas internas em detrimento da influência internacional e a política em detrimento da economia. Esses aspectos são criticados consistentemente em BUNCE, Valerie. Quand le lieu compte: specificités des passés autoritaires et réformes économiques dans les transitions à la democratie. Revue Française de Science Politique, Paris, v. 50, n. 4-5, p. 633-656, ago./out. 2000. Sobre o papel da sociedade, Branco também destaca que "se as lideranças tiveram papel político relevante, o papel da sociedade civil também foi importante, mudando apenas as características próprias da conjuntura histórica de cada caso". BRANCO, Marcello Simão. Da transição dos anos 80 para o início do século XXI, p. 28. 
Assim, essas análises conferem atenção especial para a disposição e os cálculos das elites políticas. São estas que darão o tom da mudança, a partir do jogo e das regras que instituírem nos processos de conflito e negociação, que são deflagrados e intensificados durante a transição. Sem a dimensão volitiva da política, materializada pela posição estratégica de indivíduos ou grupos-chave que exercem liderança sobre os demais, não se compreende adequadamente a instabilidade de um regime e as dificuldades postas para sua estabilização.

Dessa premissa decorre um importante recorte adotado por essa geração da transitologia. São considerados atores relevantes apenas as elites individuais ou coletivas que, por deterem recursos de poder diferenciados, destacam-se da massa dos cidadãos e determinam, prioritariamente, os rumos da comunidade política ${ }^{60}$. É evidente, dessa forma, o elitismo dessa compreensão dos jogos de poder, cujos resultados dependem apenas dos profissionais da alta política ${ }^{61}$. Estes são os responsáveis, por excelência, por formular e implementar a agenda política de uma dada transição democrática.

Essa perspectiva é assumida logo de partida, quando afirmam que a "ênfase [recai] sobre as estratégias dos atores (...) em processos de transição onde, precisamente, parte importante do jogo político consiste (...) em estabelecer as regras sob as quais se desenvolverá a sua própria competição e acordo" ${ }^{62}$, tendo em vista que, nesses momentos, as próprias regras são objeto da negociação. É bastante nítida, nesse particular, a aproximação da análise do jogo político, composto por algumas poucas regras básicas e atores relevantes (elites), com a teoria da escolha racional e, em especial, de sua particularização na teoria das escolhas estratégicas ${ }^{63}$.

\footnotetext{
${ }^{60}$ Sergio Costa chama especial atenção para essa lacuna, nesses escritos, em relação ao papel dos movimentos sociais, organizações não governamentais e outros atores que não as elites, mas que são fundamentais na conformação de uma esfera pública democrática a partir do tecido das relações sociais e da cultura política. COSTA, Sergio. Movimentos sociais, democratização e a construção de esferas públicas locais.

${ }^{61}$ A despeito da diversidade de formulações, cada uma com acentos próprios, o elitismo organiza uma parcela importante da teoria política. Se há uma única premissa básica compartilhada pelos diferentes pensadores que se alinham a essa perspectiva que se pode apontar, certamente é a do predomínio das elites e da passividade das massas por diversas razões a depender do acento, assunto que não cabe aqui explorar. Uma reconstituição interessante do elitismo e do pluralismo na teoria política, desde o pioneiro Gaetano Mosca e sua ideia de minoria organizada, passando por Vilfredo Pareto e a circulação das elites, bem como Roberto Michels e sua "lei de ferro da oligarquia" até o elitismo democrático e seus diversos representantes, encontra-se em GRYNSZPAN, Mario. A Teoria das Elites e sua Genealogia Consagrada. In: BIB - Revista Brasileira de Informação Bibliográfica em Ciências Sociais, n. 41, p. 35-83, 1996. Uma introdução geral elucidativa à teoria das elites também pode ser vista em HOLLANDA, Cristina Buarque de. Teoria das Elites. Rio de Janeiro: Zahar, 2011. p. 7-52.

${ }_{62}$ Prefácio. In: MOISÉS, José Álvaro; ALBUQUERQUE, José A. Guilhon (Org.). Dilemas da consolidação da democracia, p. 8.

63 Ainda que não caiba aprofundar, é importante registrar que a teoria das escolhas estratégicas não é mais do que uma variante específica da teoria das escolhas racionais. Cf. SANTISO, Javier. La démocratie incertaine, p. 973.
} 
Como elucida José Álvaro Moisés, "a maior parte dos autores que formam a primeira geração de estudos da transição política baseou suas análises nas teorias da escolha racional”. Ainda segundo esse autor, o modelo de análise da ação política a partir da teoria da escolha racional amplamente adotado pelos transitólogos considera que "um indivíduo se conduz racionalmente em um sentido estrito se (i) conta com um conjunto 'dado' de preferências consistentes; (ii) diante de tais preferências, persegue os meios mais adequados para maximizar seus benefícios", sendo "eficaz na hora de assegurar seu próprio interesse" ${ }^{\text {64 }}$.

Przeworski recorta a referida perspectiva a partir da ideia de uma "ação instrumental" (instrumental action) a caracterizar a lógica da movimentação desses atores $^{65}$, o que levou alguns a designarem essa perspectiva com a expressão “institucionalismo estratégico", porque enfocado nos conflitos entre as elites pró e contra o regime ${ }^{66}$.

Para essa tradição, sob as circunstâncias particulares de uma transição, há uma série de condições que possibilitam um recorte analítico centrado na figura das estratégias dos atores políticos. Nesse sentido, quando é razoável a adequação entre o desempenho dos atores políticos e as tarefas a realizar e ao mesmo tempo, quando os principais atores coletivos (classes ou grupos) neles encontram adequada representação e liderança, a análise do processo de transição pode cingir-se ao plano de jogo político ${ }^{67}$. Essa é, justamente, a regra comum nesse tipo de situação.

A importância maior é conferida, portanto, às chamadas "situações estratégicas" ou "conjunturas"68. Coerente com a centralidade das estratégicas políticas, considera-se que a mudança de uma conjuntura para outra ocorre como resultado das ações adotadas pelos atores. No entanto, é curioso notar que esses jogadores não são sempre os mesmos em conjunturas sucessivas: eles tendem a constituir-se como resultado do próprio jogo ${ }^{69}$, reconfigurando suas identidades e alianças conforme as necessidades do momento político.

\footnotetext{
64 MOISÉS, José Álvaro. Entre a "incerteza" e a tradição política, p. 89. Crítica interessante a essa orientação foi feita em texto posterior, de 1998, com certo tom de autocrítica, por Schmitter e Santiso. Eles afirmam que "momentos transicionais nunca são simples repetição de jogos, as escolhas solitárias e imediatas, ou as preferências estáveis tão intrínsecas às escolhas racionais". No original: “"transitional times' is never the simple iteration of games, the solitary and immediate choices, or the stable preferences so intrinsic to rational choices". SCHMITTER, Phillippe C.; SANTISO, Javier. Three temporal dimensions to the consolidation of democracy, p. 72. Para outro interessante estudo com maior profundidade nessa questão, cf. SANTISO, Javier. La démocratie incertaine, p. 970-993.

65 PRZEWORSKI, Adam. Democracy and Market, p. 48.

66 BRANCO, Marcello Simão. Da transição dos anos 80 para o início do século XXI, p. 6.

67 MARTINS, Luciano. Ação política e governabilidade na transição brasileira, p. 231.

68 PRZEWORSKI, Adam. Como e onde se bloqueiam as transições para a democracia?. In: MOISÉS, José Álvaro; ALBUQUERQUE, José A. Guilhon (Org.). Dilemas da consolidação da democracia, p. 20.

69 PRZEWORSKI, Adam. Como e onde se bloqueiam as transições para a democracia?, p. 20.
} 
É bastante ilustrativa da ótica adotada por essa tradição a metáfora de um jogo político transicional, como se fosse uma partida de xadrez normal, mas mais complexo e em níveis múltiplos ${ }^{70}$. As analogias entre ambos, nessa perspectiva mais figurada, são bem exploradas por O’Donnell e Schmitter. O importante a reter, dessa comparação, é a conclusão de que a própria transição consiste em inventar regras para um jogo de múltiplos níveis, tumultuado e apressado.

Przeworski, aliás, vai além nessa linha de metaforização. Em seu texto "Jogos de transição" ("The games of transition”), um capítulo ligeiramente alterado da sua já citada obra "Democracy and Market...", a imagem invocada para representar o jogo político é a de um cassino. Esse autor propõe que se

\footnotetext{
imagine que um grupo de pessoas entre em um cassino que contenha uma roleta, uma mesa de poker, um contador de blackjack e uma bancada para rolar dados. Há algum jogo que os participantes, dados os recursos que eles têm, continuarão a jogar se eles perderem algumas vezes seguidas? Em caso afirmativo, concordarão os potenciais jogadores em relação a qual jogo utilizar? Essas são questões inerentes a qualquer transição à democracia ${ }^{71}$.
}

A imagem é reveladora da opção metodológica dessa tradição, no sentido de esclarecer que, em um processo transicional, as variáveis determinantes são eminentemente e, pode-se dizer, até exclusivamente políticas. Vitullo destaca que a "terminologia lúdica" é sintomática da identificação das análises com as teorias do rational choice $^{72}$. Sob essa ótica, importam interesses, vontade e confiança por parte dos atores, bem como seus recursos de poder e como são mobilizados para as diferentes estratégias por parte das instituições. Também são fundamentais os jogos possíveis e as regras à disposição: como os atores decidem confiar e aderir a um regime e suas instituições, na relação com seus pares e suas respectivas expectativas.

A dinâmica de um jogo de regras precárias, mas com atores razoavelmente constituídos, que determina a direção da mudança política, é aceita por todos esses teóricos e reflete algo do espírito de época evocado por Schmitter. Pode-se considerar esse mais um exemplo dos pontos fortes que conferem unidade às diversas análises. As variações que existem são apenas pontuais e pouco relevantes, por exemplo, em relação aos nomes com que batizam os jogadores envolvidos e às subdivisões feitas no grupo dos que são

70 O’DONNELL, Guillermo; SCHMITTER, Philippe C. Transições do regime autoritário, p. 108 e 109.

71 No original: "imagine that a group of people enters a casino that contains a roulette wheel, a poker table, a blackjack counter, and a crap stand. Is there a game that the players, given the resources they have, will continue to play even if they lose a few times in succession? And if there is, will the potential players agree which one to play? These are generic issues inherent in any transition to democracy". PRZEWORSKI, Adam. Democracy and Market, p. 40.

72 VITULLO, Gabriel Eduardo. Além da transitologia e da consolidologia, p. 20. 
favoráveis ao regime - e em que grau o são - e, do mesmo modo, no grupo daqueles que são contrários a esse mesmo regime.

Agora, então, é possível analisar o terceiro traço característico dessa tradição, que diz respeito às articulações entre os diferentes atores e como suas interações conferem uma dinâmica própria à transição.

\subsubsection{Os atores políticos e a trama da transição}

O’Donnell e Schmitter formulam um quadro analítico que será assumido, de forma geral, como patrimônio de toda essa tradição. Distinguem quatro atores políticos ${ }^{73}$ que são estrategicamente relevantes no momento da transição e da institucionalização do novo regime, dois no campo da coalizão governante e dois no campo da oposição ao regime. São eles: os linhas-duras e os reformistas (ou brandos, que podem ou não terem se transformado em liberalizadores) dentro do establishment, e os moderados e maximalistas, na oposição ${ }^{74}$.

Por sua vez, Huntington considera que, em termos de sua atitude diante da democratização, os participantes cruciais são os seguintes: na coalizão governante, os conservadores, os reformistas liberais e os reformistas democratas; na oposição, os democratas moderados e os revolucionários extremistas ${ }^{75}$. Em relação à classificação de O’Donnell e Schmitter, somente desmembra os "reformistas" em duas subcategorias ("liberais" e "democratas"), mantendo, no essencial, a mesma estrutura.

Antes de analisar as interações estratégicas e movimentações comuns entre esses jogadores, é preciso notar a advertência que os transitólogos registram sobre essas categorias analíticas. Fazem questão de frisar que a tipologia e a classificação dos atores conforme visto acima tem finalidade eminentemente heurística, que não são atributos fixos e imutáveis dos participantes concretos ${ }^{76}$. Tampouco esses grupos seriam homogêneos.

\footnotetext{
73 Há também pessoas, grupos e organizações indecisos, que não serão estratégicos para o desenrolar e a compreensão das mudanças políticas. Por essa razão, são desconsiderados.

74 O’DONNELL, Guillermo; SCHMITTER, Philippe C. Transições do regime autoritário, p. 36. Também Przeworski assume expressamente e desenvolve esse modelo de interpretação de O'Donnell e Schmitter, "in distinguish four political actors: Hardliners and Reformers (who may or may not have been Liberalizers) inside the authoritarian bloc and Moderates and Radicals in the opposition”. PRZEWORSKI, Adam. Como e onde se bloqueiam as transições para a democracia?, p. 29.

75 HUNTINGTON, Samuel p. A terceira onda, p. 124.

76 O’DONNELL, Guillermo. Contrapontos, p. 98.
} 
Desse modo, como O’Donnell destaca, em uma nota explicativa de rodapé, “a caracterização dos membros do regime como 'linha dura' e 'linha branda' - assim como distinções similares (...) - é um recurso heurístico destinado a localizar atributos significativos de certos atores em diferentes estágios e conjunturas da transição. Essas características, portanto, não são atributos permanentes de cada ator" ${ }^{, 77}$.

Feita essa consideração preliminar, esses autores traçaram os movimentos que caracterizam um processo típico de abertura de um regime autoritário, desenhando uma transição ideal, segundo parâmetros normativos claramente reivindicados, por meio dessas categorias analíticas $^{78}$. Em verdade, organizam as interações tipificáveis em um modelo interpretativo, construído a partir de hipóteses gerais. Retomando a advertência de Schmitter, isso não implica que os destinos de todos os jogos transicionais sejam idênticos, pois as condições somente estruturam conflitos, elas não tomam decisões. Mas a estrutura das escolhas são, invariavelmente, as mesmas ${ }^{79}$.

Como regra geral que orienta esse esquema explicativo, dentre quatro grupo de atores, apenas um deseja a conservação plena do regime, que é o dos pertencentes à linhadura. Os outros três grupos desejam algum tipo de mudança, diferindo, no entanto, quanto ao sentido e ao alcance das mesmas.

Os brandos são os membros da aliança governante que, diante do elevado custo social da repressão e das dificuldades de legitimação inerentes a um regime autoritário ${ }^{80}$, tentam conduzir o processo de liberalização. O tipo de regime autocrático costuma provocar uma crescente oposição, que compõe uma coalizão de veto muito mais ampla. Cientes disso, esse movimento de abertura deflagrado pelos brandos os leva a um choque

77 O’DONNELL, Guillermo; SCHMITTER, Philippe C. Transições do regime autoritário, p. 120.

78 Em análise concreta do caso brasileiro, Luciano Martins matiza um pouco, ao menos no discurso, o peso conferido a essa "equação política", cujos termos são "reduzidos à correlação de forças entre 'democratas' e 'autoritários', em qualquer de seus matizes". Daí sustentar que se trata de "uma situação marcada também pela presença de (e o conflito entre) outros valores e interesses", ainda que não especifique exatamente quais seriam esses "valores e interesses". Esse reconhecimento, no entanto, apenas confirma a caracterização geral dessa tradição sustentada no presente trabalho de que os elementos de ordem objetiva quando são considerados, são-no apenas como externalidades da ação política ou determinações de menor relevância causal no resultado final dos acontecimentos.

79 No original: "conditions only structure conflicts, they do not make choices. But the structure of choices is the same". PRZEWORSKI, Adam. The games of transition, p. 136.

80 Sobre esse aspecto, Wanderley Guilherme dos Santos reitera que "o sonho mais caro do autoritarismo, de reduzir a imprevisibilidade social a zero, não pode ser realizado". A partir dessa constatação, ele formula a seguinte lei de ferro do autoritarismo: "um sistema autoritário não pode ser estável porque ou se expande continuamente, a fim de controlar as novas áreas relevantes da vida social, ou tem que aceitar um relaxamento relativo na medida em que os grupos fora da coalizão dominante adquirem o controle dos novos loci de poder". SANTOS, Wanderley Guilherme dos. O século de Michels: competição oligopólica, lógica autoritária e transição na América Latina [1984]. In: Rio de Janeiro: Revan, 1999. p. 115. . Paradoxos do Liberalismo: teoria e história. 
com os duros, que se opõem a qualquer transformação do regime autoritário, pois postulam o continuísmo e até mesmo um nível maior de repressão ${ }^{81}$. Por outro lado, os brandos sofrerão uma oposição direta dos maximalistas, que combaterão qualquer forma de abertura controlada ou parcial do regime ${ }^{82}$.

Vale mencionar que esses autores reservam um lugar privilegiado e de protagonismo para a relação entre dois grupos tipicamente presentes nos regimes autoritários estudados: os brandos e os moderados. A relação entre ambos é bastante peculiar no contexto transicional. Pela própria estrutura negociada da transição que assumem como ideal, é natural a atenção especial conferida a esses dois subgrupos e à virtualidade de uma aliança que os una ${ }^{83}$.

Isso porque, juntos, serão a grande força motriz das transições negociadas, o padrão das mudanças políticas exitosas, por excelência, segundo esses autores. A união dessas duas categorias de atores forma a chamada 'coalizão liberalizante" ${ }^{84}$, que, se viabilizada, será responsável por desencadear a abertura política e traçar seus contornos - e também limites - mais determinantes. Essa coalizão, se composta, acabará impondo as condições e regras do jogo para os demais atores.

Para que esse compromisso ocorra, no entanto, não basta um acordo político entre brandos e moderados: também é preciso que aqueles ganhem a ascendência sobre os linhas-duras, segurando o fechamento do regime, e que estes controlem os radicais na oposição, contendo a ânsia de transformação muito rápida e tensionadora. Essa confluência de entendimentos é necessária para que a estratégia da transição, seja qual for, possa ser levada a cabo.

Przeworski aprofunda a análise dessa dinâmica, apresentando uma tabela bastante elucidativa da sistemática de negociações. Estas sempre aparecem marcadas por ameaças, embates e acordos entre os atores relevantes. No entanto, reiterando o mencionado acima, são processos pautados, por um lado, pelos reformistas e, por outro, pelos moderados. Esses serão os dois grupos que, pela habilidade política e pelas posições privilegiadas, ditarão os rumos da mudança:

\footnotetext{
81 Daí a importância da "emergência, dentro do círculo de poder, de uma facção suficientemente poderosa para obter a concordância da 'linha dura' para uma estratégia de liberalização negociada". SANTOS, Wanderley Guilherme dos. O século de Michels, p. 116.

82 O'DONNELL, Guillermo. Contrapontos, p. 82.

83 Chega-se a afirmar que as transições negociadas para a democracia só podem resultar de entendimentos entre reformistas e moderados. PRZEWORSKI, Adam. Como e onde se bloqueiam as transições para a democracia?, p. 30.

84 O’DONNELL, Guillermo. Contrapontos, p. 82.
} 
Tabela 1 - Dinâmica do jogo transicional ${ }^{85}$

\begin{tabular}{|c|c|c|c|}
\hline & & \multicolumn{2}{|c|}{ MODERADOS se aliam com } \\
\hline & & MAXIMALISTAS & REFORMISTAS \\
\hline \multirow{2}{*}{ 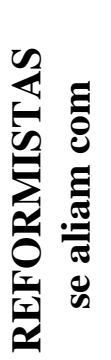 } & $\begin{array}{l}\text { LINHAS- } \\
\text { DURAS }\end{array}$ & $\begin{array}{l}\text { Golpe. Perdem os } \\
\text { Moderados e os } \\
\text { Reformistas }\end{array}$ & $\begin{array}{c}\text { O regime autoritário } \\
\text { se mantém com concessões }\end{array}$ \\
\hline & MODERADOS & $\begin{array}{c}\text { Democracia sem garantias } \\
\text { para os Reformistas }\end{array}$ & $\begin{array}{c}\text { Democracia com garantias } \\
\text { para os Reformistas }\end{array}$ \\
\hline
\end{tabular}

O quadro é autoexplicativo. De acordo com o ideal que esses transitólogos assumem, o cenário perfeito é o de uma democracia com garantias para os reformistas que compõem o bloco governista. Essa seria uma espécie de negociação sem perdedores, em que, portanto, todos ganhariam. O pior cenário, por outro lado, ocorre se um golpe é dado, impondo uma derrota à coalizão liberalizante e retornando ao regime autoritário.

Huntington formula de outra maneira essa mesma dinâmica. Partindo de um esquema teórico semelhante, esse autor sublinha outras três interações tidas como cruciais nos processos de democratização: entre governo e oposição, entre reformadores e conservadores na coalizão governante e entre moderados e extremistas na oposição ${ }^{86}$. Nesse quadrante, também a relação entre reformadores e moderados ocupa um lugar privilegiado.

Durante as negociações, há certos posicionamentos e argumentos que são comuns e recorrentes. Valendo-se das analogias lúdicas tão caras a essa tradição, pode-se dizer que existem algumas jogadas ensaiadas que são, de algum modo, previsíveis. Um grande exemplo disso é que os brandos sempre podem argumentar para a oposição que, por eles, iriam mais longe, mas que isto é impossível porque desencadearia a reação que faria tudo voltar a uma situação significativamente pior do que a que definem como a 'meta realista' a ser alcançada ${ }^{87}$.

Por outro lado, a oposição normalmente se divide em três subgrupos: a oposição oportunista (ou pseudo-oposição), que está sempre disposta a aceitar qualquer proposta

85 Adaptada de PRZEWORSKI, Adam. The games of transition, p. 119.

${ }^{86}$ HUNTINGTON, Samuel p. A terceira onda, p. 124 e 127.

87 O’DONNELL, Guillermo. Contrapontos, p. 84. 
feita pelos brandos ${ }^{88}$; a oposição maximalista, que não quererá negociar com ninguém; e a oposição democrática, que é tida como a verdadeira oposição, pois é moderada, no sentido de que está disposta a oferecer uma garantia séria e razoável de que os interesses fundamentais dos brandos e conservadores não serão atacados pela nova democracia ${ }^{89}$.

Essa configuração interna da oposição, marcada por divisões entre os que se aproximam da estratégia dos brandos e aqueles que se afastam dela, denota claramente a centralidade que os brandos têm para um processo de transição, já que ocupam uma posição intermediária entre os extremos e, portanto, maior possibilidade de trânsito entre os diferentes atores. Nessa perspectiva, a transição será tanto melhor quanto maior o nível de acordo que a orienta, acordo este que só poderá ser costurado de forma abrangente e adequada pelos próprios brandos. Por isso, a recomendação de que estes assumam a dianteira e se antecipem à mobilização dos outros setores oposicionistas, especialmente os mais radicais ${ }^{90}$.

Para a concepção compartilhada por esses autores, portanto, há um juízo de valor evidente no que diz respeito ao papel de cada um dos atores políticos: a "verdadeira oposição" 91 é aquela moderada, que se propõe a negociar e que dá a certeza de seu comprometimento com as questões fundamentais daqueles que integram o regime autoritário. Isso acarreta uma série de consequências que serão melhor exploradas mais adiante.

Por hora, é importante examinar que os brandos terão duas armas principais para levar a cabo essa estratégia de uma transição negociada e gradual, sob controle estrito e sem riscos de grandes surpresas nos rumos da mudança. Em relação a uma aliança com os duros, os brandos terão como atrativo a oferecer a garantia de que não serão afetados os interesses fundamentais daqueles, que tendem a ser problematizados no calor das mudanças políticas, especialmente se estas forem capitaneadas pelos setores contrários ao regime. Já no que concerne aos oposicionistas, tanto os moderados quanto os maximalistas, o grande trunfo dos brandos é a ameaça de uma regressão autoritária caso sejam

\footnotetext{
88 O’DONNELL, Guillermo. Contrapontos, p. 85.

89 O'DONNELL, Guillermo. Contrapontos, p. 87.

90 Tanto é assim que O'Donnell argumenta que "os regimes que se consideravam bem sucedidos foram aqueles nos quais a decisão de embarcar numa liberalização foi tomada sem um alto grau de desagregação interna ou de pressão oposicionista prévia”.

91 O’DONNELL, Guillermo. Contrapontos, p. 87. Em curto escrito sobre as tarefas da oposição nas transições de regimes autoritários, Stepan desenvolve essa importância da delimitação de um campo democrático. Cf. STEPAN, Alfred. On the tasks of a democratic opposition. In: DIAMOND, Larry; PLATTNER, Marc F. (Ed.). The global resurgence of democracy. Baltimore: The Johns Hopkins University, 1993. p. 61-69.
} 
ultrapassados os limites acordados com os duros, que pode significar a interrupção do processo e até seu retrocesso.

Nota-se, assim, que os brandos têm por função na lógica interna desse esquema analítico operar como o fiel da balança do processo transicional, jogando com todos os outros atores, para que atendam aos imperativos que a transitologia concebe a partir das experiências observadas e do ideal que assume. Pela configuração desse jogo, aliás, somente os brandos podem desempenhar a função que lhes é atribuída por essa tradição, que almeja a uma transição pactuada e gradualista.

Muitas críticas foram dirigidas a essas formulações. Ainda que reconhecendo que a perspectiva dinâmica dos atores toca no coração da dimensão estratégica das transições, Santiso aponta que os modelos são limitados pelo formalismo que os caracteriza; muito abstratos, eles sofrem talvez de uma dificuldade de capturar, nos pontos dessas redes, uma realidade muito diversificada e por vezes contraditória ${ }^{92}$. Outros, como foi visto, qualificaram de conservadora essa perspectiva, por opor a democratização política às dimensões socioeconômicas, priorizando àquela em detrimento destas últimas.

No entanto, em seu livro clássico lançado em 1991, Schmitter sai em franca defesa da abordagem referida, contextualizando e historicizando as reflexões sobre o institucionalismo estratégico nas delicadas conjunturas vividas pelos autores nesses países que então transitavam de regimes autoritários para democracias. Recupera, ainda, como elemento a justificar as deficiências dessa teorização, a participação ativa e engajada que esses transitólogos tiveram nos processos históricos experimentados. Em suma, parece tentar salvar a transitologia sob o argumento de que se tratou de um olhar interno, profundamente implicado, que se afastou tanto quanto possível do formalismo e do ahistoricismo típicos das teorias dos jogos.

Em trecho extenso que sistematiza sua análise, cuja transcrição é pertinente, o cientista político sublinha que:

a abordagem de O’Donnell e Schmitter (1986) focava-se na estratégia dos
diferentes atores e explicava os efeitos/consequências como resultado dessas
estratégias. Talvez a razão para adotar essa perspectiva seria que muitos
participantes desse projeto eram protagonistas nas lutas por democracia e
precisavam entender as consequências de cursos alternativos de ações. Ainda
que essa abordagem fosse enfocada na análise estratégica, buscava esquivar-se
de adotar uma perspectiva formalista e a-histórica inerente à abstrata teoria dos
jogos. Dado que a macrolinguagem das classes, suas alianças e 'pactos de

92 No original: “(...) les deux modèles restent cependant limités par leur formalisme; trés abstraits, ils souffrent parfois d'une difficulté à 'capturer' dans les mailles de leurs filets une réalité très diverse et parfois contradictoire”. SANTISO, Javier. La démocratie incertaine, p. 985/986. 
dominação’ eram o vocabulário dominante nesse período, o resultado foi uma microabordagem intuitiva frequentemente baseado na macrolinguagem. A principal conclusão da abordagem de O'Donnell e Schmitter era que as modalidades de transição determinam as características do novo regime. Especificamente, a menos que as forças armadas colapsem, uma transição exitosa só pode ser trazida como fruto de negociações, de pactos. A implicação política é que as forças pró-democráticas devem ser prudentes; elas devem estar preparadas para oferecer concessões na troca por democracia. E o corolário era que a democracia que resulta de uma 'ruptura pactada' (negotiated break) é inevitavelmente conservadora economicamente e socialmente. Uma vez que a democracia tenha sido estabilizada em diversos países, essas conclusões receberam a acusação de serem conservadoras. Esse juízo de valor retroativo é fácil de sustentar, particularmente para observadores a salvo nas paredes da academia norte-americana. Ainda, para muitos protagonistas, a questão política central nessa época era se a luta deveria ser simultaneamente por transformação política e econômica ou apenas sobre questões políticas ${ }^{93}$.

Independentemente da avaliação que se faça em relação a essa polêmica, dando ou não razão à leitura de Przeworski e às posições apresentadas, o fato é que a transitologia priorizou, para os resultados das mudanças, as estratégias adotadas pelos atores políticos relevantes. Nesse quadrante, considerando a importância das saídas negociadas, emergiram, com especial relevância, as formas de composição dos conflitos por meio de pactos, ponto que será examinado a seguir.

\subsection{Modos de transição: a preferência pelos pactos democratizadores}

Outra temática bastante presente nas reflexões dessa geração de cientistas políticos refere-se ao modo como as transições ocorrem, ou seja, o "como" da mudança política. Geralmente, visavam-se às estratégias empregadas pelos atores relevantes,

93 No original: “the O’Donnell-Schmitter (1986) approach was to focus on the strategies of different actors and explain the outcomes as a result of these strategies. Perhaps the reason for adopting this approach was that many participants in their project were protagonists in the struggles for democracy and needed to understand the consequences of alternative courses of action. Yet while this approach focused on strategic analysis, it shied away from adopting a formalistic, ahistorical approach inherent in the abstract theory of games. Given that the macrolanguage of classes, their alliances, and 'pacts of domination' was the dominant vocabulary of the time, the result was an intuitive micro approach often couched in macro language. The main conclusion of the O'Donnell-Schmitter approach was that modalities of transition determine the features of the new regime; specifically, that unless the armed forces collapse, successful transition can be brought about only as a result of negotiations, of pacts. The political implication was that pro-democratic forces must be prudent; they must be prepared to offer concessions in exchange for democracy. And the corollary was that the democracy that results from the ruptura pactada (negotiated break) is inevitably conservative economically and socially. Once democracy had been established in several countries, these conclusions drew the accusation that they were unduly conservative. Such retrospective evaluations are easy to support, particularly for observers tucked safely away within the walls of North American academia. Indeed, for many protagonists, the central political issue at that time was whether their struggle should be simultaneously for political and economic transformation or only be about political issues". PRZEWORSKI, Adam. Democracy and Market, p. 97/98. 
verificando se tendiam mais à confrontação ou, ao contrário, à acomodação. Esse foi um dos critérios mais prestigiados, nos primeiros estudos, para operar uma classificação entre as transições que introduzem uma quebra com o antigo regime e aquelas que avançam dentro do quadro legal-institucional existente ou a partir de acordos entre as elites dirigentes (pró e contra o regime).

Essa questão específica ficou conhecida como "modos de transição" e mereceu estudos bastantes interessantes que, basicamente, procuraram apurar como as diferentes transições influenciam os desenvolvimentos políticos posteriores. O mais consagrado desses trabalhos, partindo da constatação da insuficiência desse critério único, propõe uma definição dos modos de transição que conjuga, além das estratégias adotadas pelos atores, a identidade do principal agente impulsionador da mudança. Em outras palavras, a preocupação é saber se uma transição é realizada por elites dentro da estrutura de poder estabelecida, por contra-elites que desafiam as elites situacionistas ou por alguma combinação das duas. Nessa linha, o fator distintivo das transições seriam "definidos pela identidade do ator ou atores que pressionam por mudança, e pelas estratégias que esses atores adotam ao desafiar o antigo regime", enfatizando o quem e o como das transições"94.

Aqui é pertinente registrar a advertência de que esse modelo é artificial e com fins meramente analíticos, pois não há, na realidade, uma diferenciação estanque e de contornos tão nítidos que separem essas modalidades de transição. Até mesmo porque deve-se ressaltar o fato de que as instituições políticas decorrentes de uma transição, em verdade, sempre emergem de negociações ${ }^{95}$.

O que parece ser determinante, em verdade, para diferenciar os casos particulares é se e em que medida as negociações, além de envolver os oposicionistas pró-democracia, envolvem também forças associadas ao regime autoritário em superação ${ }^{96}$. A presença e o

94 MUNCK, Gerardo L.; LEFF, Carol Skalnik. Modos de transição em perspectiva comparada. Lua Nova: Revista de Cultura e Política, São Paulo, n. 40/41, p. 69-95, 1997. p. 71-73.

95 Como destaca Przeworski, “(...) todas as transições para a democracia são negociadas: algumas com representantes do antigo regime e outras apenas entre as forças pró-democráticas buscando formar um novo regime. Negociações nem sempre foram necessárias para desenredar (liberar) a sociedade de um regime autoritário, mas elas são necessárias para constituir instituições democráticas. A democracia não pode ser ditada; ela emerge de negociação”. No original: “(...) all transitions to democracy are negotiated: some with representatives of the old regime and some only among the pro-democratic forces seeking to form a new system. Negotiations are not always needed to extricate the society from the authoritarian regime, but they are necessary to constitute democratic institutions. Democracy cannot be dictated; it emerges from bargaining”. PRZEWORSKI, Adam. Democracy and Market, p. 80. Huntington, por sua vez, defende expressamente que uma negociação entre governo e oposição é a regra: "quase todas as transições envolvem uma certa negociação - explícita ou implícita, aberta ou oculta - entre governo e oposição". HUNTINGTON, Samuel p. A terceira onda, p. 118.

96 No original: "I argue that such institutions [escolhidas durante a transição para a democracia] always emerge from negotiation. What differentiates particular cases of transition is whether these negotiations 
peso destas constituem um dos fatores fundamentais para explicar a forma como se desdobra um processo de mudança política e as características peculiares de um regime pós-transição, especialmente sua relação com o legado do autoritarismo.

É evidente que o modo de transição deixa marcas importantes no funcionamento da democracia recém-estabilizada. Ainda que não seja o único fator ou mesmo o mais relevante para explicar as características do governo que sucede a transição, é inegável que, em alguma medida que só poderá ser estimada empiricamente, contribui de maneira direta tanto para as potencialidades quanto para as deficiências que marcarão o regime democrático recém instituído ${ }^{97}$.

Nesse sentido, a despeito do especial destaque conferido aos pactos como um meio privilegiado de solução das crises de governabilidade e da sucessão entre regimes, outras formas de efetivação das mudanças políticas também são consideradas.

Em vários dos textos analisados, projeta-se uma tipologia das transições segundo o grau de embate entre os atores políticos relevantes. Por exemplo, tomando como critério a iniciativa da ação transformadora, Huntington vai classificar três tipos amplos de processo, na mesma linha de Juan Linz (apenas alterando a nomenclatura): a transformação (ou, na expressão de Linz, reforma) ocorreu quando as elites no poder lideraram a criação da nova democracia; a substituição (ruptura, para Linz) ocorreu quando tal papel foi desempenhado por grupos de oposições e o regime autoritário entrou em colapso ou foi derrubado; por fim, o terceiro tipo é o que pode ser denominado de transtituição ou

involve the forces associated with the previous authoritarian regimes or only the allies in the struggle against authoritarianism”. PRZEWORSKI, Adam. Democracy and Market, p. XI.

$97 \mathrm{O}$ tratamento jurídico a ser conferido às violações de direitos humanos, que será discutido no próximo capítulo, é um exemplo privilegiado dessa influência do modo de transição na democracia emergente. De acordo com o jurista Carlos S. Nino, podem-se classificar as transições de acordo com três critérios: (i) modalidade (por força ou por consenso); (ii) etiologia (endógena ou exógena); e (iii) estado jurídico em relação ao regime anterior (continuidade, ruptura ou restauração). Ponderando essas variáveis e suas consequências para a definição do tratamento jurídico-político dispensado aos membros do regime anterior por novos governos, dirá esse autor que "una variable clave podría ser el tipo de transición en el que el gobierno estaba embarcado. (...) Cuando la transición es más coercitiva, un nuevo balance de poder contribuye en forma positiva a las posibilidades de la justicia retroactiva. (...) En cambio, cuando la democractización se realiza a través de negociaciones destinadas a logra consenso, la justicia retroactiva tiene menos posibilidades de éxito". Acrescenta que quando "el nuevo regimén democrático es una continuidad jurídica del viejo regimén autoritario y las violaciones de derechos humanos a ser llevadas a juicio están protegidas, por ejemplo, por una ley de amnistía, y los princípios contra de la derogación ex post facto garantizan la protección legal, exiten enormes obstáculos para la justicia retroactiva" e, ao contrário, "cuando existe un rompimiento jurídico completo, el camino de la justicia retroactiva resulta más sencillo". Afirma ainda que "cuanto más graves son los abusos de los derechos humanos, existen más posibilidades de que el intento de hacer justicia tenga éxito". Por fim, indica que "el lapso temporal que transcurre entre el momento en que se cometen las atrocidades y aquel en que se intenta realizar la justicia retroactiva tanbién ayuda para explicar su éxito relativo". NINO, Carlos. Juicio al mal absoluto. Buenos Aires: Emecé; Ariel, 2006. p.169191. 
"ruptforma", em que há uma ação conjunta dos grupos de governo e oposição, marcada pela negociação, portanto ${ }^{98}$.

Dentre os casos agrupados nessa última categoria de arranjos mais marcados pela acomodação entre os grupos em disputa, despontam com grande destaque os pactos políticos ${ }^{99}$, que remetem diretamente à ideia de negociação entre as elites dirigentes. Segundo O'Donnell e Schmitter, um pacto pode ser definido como um acordo explícito, mas nem sempre publicamente explicado ou justificado entre um conjunto de atores, na busca de definir (ou redefinir) regras cujo sentido orienta seu comportamento político com base em garantias mútuas relativas aos 'interesses vitais' dos pactuantes ${ }^{100}$.

Esse tipo de compromisso tem o condão de converter, ao menos temporariamente, o confronto entre os atores em uma convivência relativamente harmoniosa, que pauta o dissenso dentro das regras previamente convencionadas. Essa função quase mística do pacto chegou a ser designada como uma "transformação de alquimia"101. De algum modo,

98 HUNTINGTON, Samuel p. A terceira onda, p. 118. O’Donnell pontua uma distinção entre dois conjuntos de casos. A primeira família de casos de Estados burocrático-autoritários refere-se aos regimes economicamente destrutivos e altamente repressivos (Argentina, Uruguai, Bolívia, Chile e Grécia). Esses regimes "costumam terminar por colapso, devido a uma explosão de conflitos internos aos mesmos, ajudada por uma oposição maciça embora silenciada durante muito tempo pela repressão. Em alguns casos, esses regimes precipitam seu colapso ao projetar para o exterior seus problemas internos e empreender alguma aventura bélica. O colapso leva a um tipo de transição na qual, embora não deixe de haver negociações, os governantes autoritários não conseguem controlar a agenda de temas em negociação nem os resultados da mesma e pende sobre a cabeça dessas democracias a ameaça de morte rápida por um golpe". Por sua vez, na segunda família de casos, "o regime autoritário foi relativamente bem sucedido economicamente e, embora não tenha deixado de aplicar uma dura repressão, esta foi significativamente menos extensa e sistemática (Brasil, Equador e Espanha). As transições nestes regimes não são por colapso; são transições 'transadas' mediante acordos ou pactos (...) os governantes de regimes autoritários (...) costumam obter um alto (embora declinante com o correr do tempo) controle sobre os ritmos e agendas da transição". O'DONNELL, Guillermo. Transições, continuidades e alguns paradoxos. In: ___ REIS Fábio Wanderley (Org.). A democracia no Brasil: dilemas e perspectivas. São Paulo: Vértice; Revista dos Tribunais, 1988. p. 49-51. E arremata que "os estudos sobre transições de regimes autoritários parte, com poucas exceções, da premissa de que o segundo grupo de casos acima discutido teria que ser mais favorável do que o primeiro para a consolidação da democracia” (p. 57). Essas duas classificações já são suficientemente exemplificativas do conjunto das obras analisadas. Não serão aqui aprofundadas as demais tipologias apresentadas por cada um desses autores, que variam pouco em relação a essas elaborações. O importante a reter, para a tese desse trabalho, é que há diferentes modalidades de transição, segundo o grau de acordo e embate entre as forças de oposição e as do regime, critério privilegiado por essa tradição. A despeito dessa diversidade de formatos, a transição mais adequada, na visão normativa desses autores, é sempre aquela que implica menor grau de conflito e mobiliza o maior nível de consenso possível, pois carrega maior potencial de continuidade do processo transicional. No entanto, como efeito colateral, dificulta a radicalização da democracia, preço este a ser pago para se alcançar a democracia.

99 Privilegia-se, nessa tradição, a dimensão política dos pactos, em especial as regras e as instituições que são estabelecidas em decorrência do acordo. Registra-se, contudo, que normalmente englobam matérias substanciais de ordens econômica, social, cultural etc.

100 O’DONNELL, Guillermo; SCHMITTER, Philippe C. Transições do regime autoritário, p. 67.

101 “(...) the role of democratic pact is to effect just such an alchemical transformation". PRZEWORSKI, Adam. Democracy and Market, p. 39. 
podem ser caracterizados como "acordos para desacordos"102 e o único jeito de alterá-los é por uma mudança institucional, que só pode ser atingida pela via do consenso entre os atores politicamente relevantes.

Os pactos mencionados podem assumir diversas características a depender do contexto. Podem ser mais abrangentes, envolvendo um grande número de atores, ou mais restritos, estabelecendo filtros de participação e excluindo determinados setores ${ }^{103}$. Seus conteúdos substanciais variam, a depender da dinâmica da transição e da correlação de forças entre os atores tidos como relevantes. Podem dispor de questões materiais e interesses imediatos das forças políticas em confronto até de temas de relevância de toda a sociedade.

Contudo, via de regra, têm de tratar, no mínimo, dos procedimentos e normas que estabilizarão o jogo político sob novo regime ${ }^{104}$. Quanto à forma, variam desde os mais expressos e formalizados, até os mais ocultos e tácitos, eis que, por vezes, não podem ser assumidos abertamente perante a opinião pública e o conjunto dos atores políticos relevantes.

É preciso considerar, no entanto, que nem sempre os pactos são possíveis, pois dependem de diversos fatores - conjunturais e subjetivos - para serem viabilizados. Em determinados contextos, os pactos podem ser completamente bloqueados pelas circunstâncias.

Mas há cenários nos quais são facilitados e até compulsórios para alguns jogadores, tendo em vista a dimensão coercitiva que podem assumir, forçando certos atores a se submeterem a seus termos. É preciso frisar esse aspecto: não existem, em uma situação transicional, a plena liberdade e a igualdade originária de pontos de partida dos atores $^{105}$. Antes, a potência política diferente detida por cada um e a força de mobilização

\footnotetext{
102 "They are agreements to disagree. And the only way to change these conditions by agreement is to form new institutions". PRZEWORSKI, Adam. Democracy and Market, p. 39.

${ }^{103}$ Essa dimensão excludente e até perniciosa de alguns pactos para a continuidade das transições é sublinhada por Przeworski: “(...) pactos políticos são cartéis de participantes do poder contra seus contendores, restringem a competição, bloqueiam o acesso e distribuem benefícios em termos de poder político entre seus participantes. Seu efeito é retardar o processo de transição ou até mesmo bloqueá-lo definitivamente". PRZEWORSKI, Adam. Como e onde se bloqueiam as transições para a democracia?, p. 38. 104 "No núcleo do pacto reside um compromisso negociado, nos termos do qual os atores concordam em deixar de lado, ou em subutilizar, sua capacidade de infligir danos uns aos outros, mediante a extensão de garantias de que não ameaçarão reciprocamente as autonomias corporativas ou interesses considerados vitais pelas partes”. O’DONNELL, Guillermo; SCHMITTER, Philippe C. Transições do regime autoritário, p. 68.

${ }^{105}$ Nesse sentido, "as regras podem ser impostas unilateralmente por um ator dominante, devendo os demais jogadores obedecer por medo ou respeito, ou elaborar-se-iam multilateralmente por acordos implíticos ou pactos explícitos. As regras, em algum momento podem ser reunidas num único manual - a constituição mas é provável que arranjos informais e normas de prudência as completem (e algumas vezes as elidam). O'DONNELL, Guillermo; SCHMITTER, Philippe C. Transições do regime autoritário, p. 111.
} 
que possuem são determinantes para o encaminhamento de suas demandas e expectativas, muitas vezes mediante a coação dos demais.

São especialmente propícios se satisfeita uma das seguintes condições: (i) sociedade é fracamente organizada e politicamente inativa ou (ii) inversamente, quando os níveis de organização social e ativação política são relativamente altos e há um sistema partidário razoavelmente forte e representativo. No primeiro caso, há acordos elitistas e exclusivistas; no segundo, os compromissos são mais abrangentes e os acordos políticos mais institucionalizados ${ }^{106}$.

Desse modo, como se nota, são inteiramente contingentes, dependentes das correlações políticas de força. Nos casos em que são possíveis, contudo, são certamente a melhor e mais adequada alternativa à disposição dos atores. Com efeito, independentemente dos traços concretos assumidos por um pacto político em um contexto transicional particular, na visão dessa corrente de cientistas políticos, trata-se do instrumento ideal de superação do regime autoritário e de construção de uma nova democracia. Segundo essa ideia, cara ao modelo analítico em discussão, as transições serão tão mais bem sucedidas quanto maior o nível de consenso no sistema político, especialmente entre os setores governistas e as forças de oposição.

Nesse sentido, O’Donnell e Schmitter são dos mais explícitos do conjunto de autores. Afirmam categoricamente que "nossa conclusão factual - enunciada acima como preferência normativa - é que, para estes países a única rota para a democracia política, é pacífica e negociada, baseada na liberalização inicial e na subsequente introdução de instituições de competição eleitoral, representação de interesses e responsabilidade executiva - com os custos, compensações e incertezas que um curso desses implica"107.

${ }^{106}$ Cf. O’DONNELL, Guillermo. Introdução aos casos latino-americanos. In: ; SCHMITTER, Philippe C.; WHITEHEAD, Laurence (Org.). Transições do regime autoritário: América Latina. São Paulo: Vértice: Revista dos Tribunais, 1988. p. 28. Esse mesmo autor, evocando Otto Kirchheimer, vai trazer à tona a ironia dos pactos modernos enquadrados na primeira categoria: "fundamentados em complexas concessões mútuas entre grupos públicos e privados, na mútua garantia do seu direito coletivo de participar do processo de tomada de decisões e do seu respectivo privilégio de representar e assegurar interesses considerados vitais pelos respectivos participantes (...) levam a comunidade política à democracia por meios não democráticos". O’DONNELL, Guillermo; SCHMITTER, Philippe C. Transições do regime autoritário, p. 68.

107 O’DONNELL, Guillermo; SCHMITTER, Philippe C. Transições do regime autoritário, p. 62 e 63 . Outro benefício da saída negociada e gradual é apontado por Sanguinetti, um dos artífices da redemocratização uruguaia. Para ele, "o diálogo entre os líderes políticos e militares nos permitem conhecer um ao outro. Os políticos aprendem a entender o raciocínio dos militares e estes aprenderam a negociar e comprometer-se". No original: "the dialogue between the political and military leaders permitted us to get to know each other. The politicians learned to understand military reasoning, and the military learned to negotiate and compromise". SANGUINETTI, Julio María. Present at transition. In: DIAMOND, Larry; PLATTNER, Marc F. (Ed.). The global resurgence of democracy. Baltimore: The Johns Hopkins University, 1993. p. 53-60. p. 57. 
Mais adiante, relativizam um pouco o valor universal dessa conclusão, ressalvando que não se podem excluir situações de ruptura mais marcadas, que tenham por fundamento não uma transformação gradual, mas um evento dramático ${ }^{108}$. Isso, no entanto, não atenua, ao cabo, a força e a intensidade que depositam na aposta pelas saídas negociadas. Não por outra razão, arrematam que "os pactos, portanto, nem sempre são prováveis ou possíveis, mas estamos convencidos de que onde se aplicam aumentam a probabilidade da viabilidade da democracia política"109.

Observa-se, destarte, no esquema proposto por esses estudiosos, uma flagrante preferência normativa por saídas negociadas dos regimes autoritários, tidas como as mais adequadas para consumar uma efetiva democratização. Tanto é assim que, como visto anteriormente, o protagonismo e o controle da transição, idealmente, devem estar concentrados nas mãos dos oposicionistas brandos. Por excelência, são estes a única categoria de atores capazes de negociar, ao mesmo tempo e com argumentos de apelo, tanto com os governistas linha-dura quanto com os oposicionistas mais radicais.

Mas, considerando que os pactos chancelam correlações de força muito dinâmicas e instáveis, o que ocorre quando essas condições se modificam e os próprios atores tentam reconfigurar as regras que estabilizam determinada comunidade política? Esse é um tema central para aferir em que medida a teoria das transições pode comportar a inserção de demandas de justiça em momentos posteriores, como será visto a seguir.

\subsubsection{Revendo os pactos políticos}

Para essa tradição de estudiosos, em suma, os pactos estão intimamente associados à pretensão de lograr-se uma estabilidade minimamente harmônica, ainda que precária e momentânea. Isso porque, vale frisar, os compromissos políticos não constituem um fim em si mesmo. Antes, expressam um nível de acordo e entendimento que os qualificam como um dos meios mais promissores e seguros para o êxito de uma transição política. Por isso, são, com frequência, considerados como "soluções temporárias

\footnotetext{
108 “Embora não estejamos afirmando serem esses arranjos características necessárias de uma transição bem sucedida, acreditamos que eles podem desempenhar um importante papel em qualquer mudança de regime que tenha como fundamento uma transformação gradual em lugar de um evento dramático". O'DONNELL, Guillermo; SCHMITTER, Philippe C. Transições do regime autoritário, p. 67.

109 O’DONNELL, Guillermo; SCHMITTER, Philippe C. Transições do regime autoritário, p. 70.
} 
destinadas a evitar resultados preocupantes e, talvez, a sedimentar o caminho para acordos de caráter mais permanente para a resolução de conflitos" ${ } 110$.

Dessa maneira, as condições excepcionais sob as quais os pactos são negociados e concluídos justificam, na perspectiva desses autores, o senso de prudência e de cautela que impõe uma obediência rigorosa à lógica das possibilidades ${ }^{111}$. Frequentemente, os atores deverão escolher entre obter um "mínimo" - aceitável pelas outras partes da contenda - ou, se insistirem no "máximo", poderão terminar absolutamente sem nada, forçando-se a um rebaixamento das pautas, sobretudo a dos oposicionistas radicais. Além disso, não se pode perder de vista que o clima de insegurança quanto ao futuro e o medo quanto a um novo golpe, sempre presentes nas transições, impedem que a negociação ocorra em seu formato ideal, com igualdade de posições e forças de barganha equivalentes.

Pelo contrário, na realidade, os atores se veem premidos pela urgência de alcançar uma solução antes que seja tarde demais, o que faz com que sejam obrigados, na maior parte das vezes, a ceder às saídas moderadas e negociadas, sob pena de que os conflitos atinjam um nível intolerável que pode levar à dissolução completa do sistema político - ou, o que é pior, a um novo fechamento autoritário -, e ao esgarçamento do tecido social. Daí a impressão de que a escolha das instituições nas transições analisadas por esses autores tenha sido casual e aleatória, motivada basicamente pelo desejo compreensível de encerrar os conflitos fundamentais o mais breve possível ${ }^{112}$.

Esse drama é acentuado diante do paradoxo da crise do regime vigente sem que, contudo, sua superação imediata seja viável. Porque esse tipo de conjuntura é normalmente marcada pela ambiguidade de um regime em decadência que insiste em manter o controle pela força e por uma oposição incapaz de angariar o apoio político necessário para renovar as estruturas de governo e as regras do jogo.

Dessas ambivalências e tensões, típicas das transições concretizadas pelas negociações entre as elites, é que decorre a natureza instável e provisória dos pactos políticos. Por se tratar de concessões parte-a-parte, apenas um número restrito de atores sentem-se contemplados plenamente em seus desejos, a depender da pressão social e da representatividade que encarnam para impor suas condições. Isso enseja uma vinculação frouxa entre os convenentes do pacto, que raramente estarão satisfeitos com as cláusulas

110 O’DONNELL, Guillermo; SCHMITTER, Philippe C. Transições do regime autoritário, p. 67.

111 Mais adiante será melhor tratada essa ideia de uma lógica das possibilidades que se impõe como restrição ao horizonte dos agentes democratizadores.

${ }^{112}$ Nas palavras de Przeworski: "it seems that the choice of institutions during recent cases of transition has been to a large extent haphazard, dominated by the understandable desire to terminate fundamental conflicts as quickly as posible". PRZEWORSKI, Adam. Democracy and Market, p. 94. 
vigentes e, quando não as descumprirem deliberadamente, sabotando o que foi ajustado, provocarão, na primeira oportunidade, uma tentativa de renegociação dos termos pactuados.

De acordo com essa leitura, todos os pactos carregam em si mesmos a permanente virtualidade de revisão, cuja consumação dependerá de alterações nas posições de poder ocupadas por cada um dos atores relevantes e seus respectivos interesses. Um pacto sempre estará lastreado, essencialmente e tão somente, pela correlação de forças que o ensejou. Por isso que o horizonte de incerteza, característico da transição, também assola os lapsos de segurança e estabilização propiciados pelos compromissos negociados, que nunca terão a solidez necessária para oferecer uma garantia plena e inquestionável aos jogadores e cuja continuidade, periodicamente, será posta em questão ${ }^{113}$. São tão contingentes quanto as próprias transições.

Essa constatação é pacificamente aceita por esses atores. O’Donnell e Schmitter, por exemplo, aventam que as modificações subsequentes ao pacto nas relações entre os atores e a emergência de novos atores que não podem ser ignorados e que desejam entrar no jogo tendem a impor a necessidade de renegociação, senão de dissolução, dos pactos existentes $^{114}$.

Uma atenção mais detalhada e sistemática a esse aspecto foi dispensada por Schmitter. Em virtude da situação especial em que os pactos são selados, sua recomendação principal é no sentido de que os atores devam ser extremamente prudentes nos momentos que precedem a celebração do acordo (ex ante), para evitar a recaída autoritária. Esse postulado, desnecessário repisar esse ponto, é bastante coerente com todas as premissas que orientam suas reflexões em torno das transições.

No entanto, ainda conforme esse autor, após a pactuação dos direitos e deveres recíprocos (ex post), a situação se modifica, pois os atores desejam ser mais resolutos. Deve-se reconhecer, nesse particular, que as decisões feitas ex ante criam condições difíceis de reverter ex post, dado que preservam o poder das forças associadas ao antigo regime, recolocando na ordem do dia a ameaça não de uma morte rápida, mas de uma morte lenta da transição. O dilema é formulado de maneira bastante precisa por esse autor,

\footnotetext{
113 Em se tratando de uma transição do autoritarismo para a democracia (por desprendimento, libertação "transition by extrication"), essa instabilidade é potencializada: "Transition by extrication generates incentives for the democratic forces to remove the guarantees left as the authoritarian legacy. Hence, it leaves an institutional legacy that is inherently unstable". PRZEWORSKI, Adam. Democracy and Market, p. 79.

114 O’DONNELL, Guillermo; SCHMITTER, Philippe C. Transições do regime autoritário, p. 70.
} 
ao afirmar que "ex post, as forças democráticas arrependem-se de sua prudência, mas, ex ante, elas não tem escolha alguma senão serem prudentes"115.

Ainda que as condições previamente pactuadas imponham determinados limites e parâmetros para as renegociações que eventualmente seguirão, não são absolutas e irreversíveis. Recoloca-se, quanto a esse aspecto, a já mencionada incerteza referencial definidora da democracia política. Segundo esse princípio, caro aos pensadores considerados, o "traço essencial da democracia é que nada é decidido definitivamente". Isso porque, considerando que a soberania é detida pelo povo, este pode decidir por "minar todas as garantias alcançadas pelos políticos na mesa de negociações. Mesmo as mais institucionalizadas garantias logram, no máximo, um alto grau de confiança, nunca uma certeza" $^{, 116}$.

Em suma, já aparece no pensamento de alguns dos autores uma abertura quanto à possibilidade de revisão dos pactos transicionais, que poderão ser reelaborados à luz das mudanças posteriores no processo de democratização. No entanto, essa brecha é bastante estrita e inacessível, pois em se tratando de mudanças pactuadas, dificilmente ocorrem reconfigurações significativas e profundas nas correlações de força. Particularmente, há determinados aspectos intocáveis, que só poderão ser postos na mesa de negociação, pacificamente, se houver garantias mútuas de que certos limites serão respeitados.

Nesse sentido, de acordo com a dinâmica minuciosamente descrita, há determinados pontos que são verdadeiramente blindados às negociações e às mudanças, mesmo durante os momentos transicionais. Trata-se, aqui, dos chamados "interesses fundamentais da coalizão autoritária", que, a depender do poder residual que esses setores conservam, poderão ser completa ou parcialmente interditados no processo de democratização.

\footnotetext{
${ }^{115}$ No original: "Hence, the optimal strategy of extrication is inconsistent. The forces pushing for democracy must be prudent ex ante, and they would like to be resolute ex post. But decisions made ex ante create conditions that are hard to reverse ex post, since they preserve the power of forces associated with the ancien régime. Ex post the democratic forces regret their prudence, but ex ante they have no choice but to be prudent". PRZEWORSKI, Adam. Democracy and Market, p. 78/79. Nesse particular, conclui que "quando o antigo regime negocia sua saída do poder, a estratégia ideal de democratização é inconsistente: requer compromissos ex ante, determinação (poder de resolução) ex post". No original: "whenever the ancien régime negotiates its way out of power, the optimal strategy of democratization is inconsistent: It requires compromises ex ante, resolution ex post". PRZEWORSKI, Adam. Democracy and Market, p. 94.

${ }^{116}$ No original: "Yet the conditions created by transitions negotiated with the ancien régime are not irreversible. The essential feature of democracy is that nothing is decided definitively. If sovereignty resides with the people, the people can decide to undermine all the guarantees reached by politicians around the negotiating table. Even the most instituionalized guarantees give at best a high degree of assurance, never certainty". PRZEWORSKI, Adam. Democracy and Market, p. 79.
} 
A questão merece um tópico à parte, pois diz respeito, diretamente, às medidas de justiça que podem ou não ser empreendidas durante a transição, dando lugar à discussão em torno do conceito de justiça transicional. Essas medidas, é inevitável, esbarrarão exatamente nos interesses fundamentais dos setores egressos do regime autoritário e que lhe davam sustentação. É isso que se passará a analisar. 


\section{A TRANSIÇÃO JUSTA: ENTRE AS DEMANDAS MORAIS E O IMPERATIVO DE ESTABILIZAÇÃO POLÍTICA}

Nesse capítulo, será discutida a ideia de uma transição justa, inicialmente na tradição de cientistas políticos examinada no capítulo anterior e, em seguida, na nova literatura que tem delimitado o conceito de justiça de transição.

Contudo, antes de passar à discussão sobre a dimensão da justiça nos processos de transição, é pertinente examinar o que esses transitólogos entendem por interesses fundamentais dos que participam do regime autoritário. Isso porque, caso não sejam preservados esses interesses fundamentais durante as mudanças, haverá o risco de que o processo transicional seja abortado e de que o regime político se feche novamente, até mesmo aprofundando seu caráter autoritário.

Como se verá, esse risco constitui uma preocupação preliminar e prejudicial às demais tarefas que caberiam à transição, modulando a percepção de justiça desses autores. Por essa razão, primeiro será analisado esse temor da regressão autoritária e seus impactos na estratégia dos autores. Logo em seguida, será abordada a tensão entre os interesses fundamentais dos egressos do regime autoritário e as demandas de justiça por parte dos que sofreram os atos de repressão política e violência.

\subsection{A ameaça da regressão autoritária: a espada de Dâmocles na transição}

De início, é preciso pontuar que, para esses autores, cuja inquietação maior era garantir as condições de possibilidade para que a transição se consumasse rumo à democracia, o pior cenário seria a regressão autoritária. Daí, inclusive, a presença marcante da cautela e da prudência que caracteriza, intensamente, o pensamento deles, sempre marcado por um rigoroso juízo sobre a conveniência e a oportunidade da oposição 
pressionar duramente por mudanças, diante do medo de que se materialize, em virtude de qualquer movimentação excessiva e/ou indevida, o fantasma da regressão.

A expressão "Espada de Dâmocles" é uma alusão à anedota moral descrita por Marco Túlio Cícero em seus escritos conhecidos como Disputas Tusculanas ("Tusculan Disputations"). Nesse texto, esse autor escreve que Dâmocles era um bajulador do tirano Dionísio, de Siracusa, que invejava seu poder e riqueza. Este, então, permite que Dâmocles ocupe seu lugar por um dia, tendo tudo o que quiser. No entanto, deixa uma espada pendurada em um fio de cabelo de cavalo sobre a cabeça de Dâmocles, que não consegue aproveitar nada do que lhe é oferecido por conta do receio de que a espada caia. Representa, assim, uma ameaça que paralisa pelo medo ${ }^{117}$.

Isso porque, nos jogos de poder que definem os rumos das mudanças, os membros dessa tradição entendem que uma das principais incertezas da transição é determinar se as pressões liberalizantes serão fortes o suficiente e na medida correta para provocar um deslocamento no sentido pretendido de democratização. No entanto, não podem ser "não fortes ou prematuras demais (em termos do campo de força existente em qualquer momento da transição) para provocar uma regressão autoritária"118.

Como faz questão de ressaltar O’Donnell, para sustentar esse argumento da ameaça da regressão, a possibilidade de um golpe não é fictícia, pois por mais divididos entre si que os proponentes da transição se encontrem, em termos de temas substantivos e de procedimentos, eles compartilham um interesse básico e essencial: evitar o golpe ${ }^{119}$.

\footnotetext{
${ }^{117}$ Vale reproduzir as palavras desse autor: "Dionísio mandou que ele [Dâmocles] se deitasse em uma cama de ouro com a mais bonita cobertura, enfeitada e produzida pelo trabalho mais refinado, e ele revestiu um grande número de aparadores com prata e ouro em relevo. Então ele mandou alguns jovens, destacados por sua beleza, para esperar à mesa, e a observar seu aceno com a cabeça, para servi-lo com o que ele quisesse. Havia unguentos e coroas; perfumes eram queimados; mesas ofereciam as mais requintadas refeições. Dâmocles pensou que estava muito feliz. No meio desses aparelhos, Dionísio mandou que uma espada reluzente fosse pendurada no teto, suspensa por um único fio de cabelo de cavalo, de modo a pairar sobre a cabeça daquele homem feliz. Depois disso, ele [Dâmocles] nem lançou seu olhar àqueles criados, nem ao prato bem feito; tampouco tocou algum dos mantimentos: nessa hora, a coroa sentia-se em pedaços". No original: "(...) Dionysius ordered him to be laid on a bed of gold with the most beautiful covering, embroidered and wrought with the most exquisite work, and he dressed out a great many sideboards with silver and embossed gold. He then ordered some youths, distinguished for their handsome persons, to wait at his table, and to observe his nod, in order to serve him with what he wanted. There were ointments and garlands; perfumes were burned; tables provided with the most exquisite meats. Damocles thought himself very happy. In the midst of this apparatus, Dionysius ordered a bright sword to be let down from the ceiling, suspended by a single horse-hair, so as to hang over the head of that happy man. After which he neither cast his eye on those handsome waiters, nor on the well-wrought plate; nor touched any of the provisions: presently the garlands fell to pieces". CÍCERO, Marco Túlio. Tusculan Disputations. New York: Harper \& Brothers, 1877 [708 a.C.]. Disponível em: <http://www.gutenberg.org/files/14988/14988-h/14988-h.htm>. Acesso em: 15 jan. 2012. p. 186. A pintura que consta no início do trabalho refere-se exatamente a essa estória.

118 O'DONNELL, Guillermo; SCHMITTER, Philippe C. Transições do regime autoritário, p. 28.

119 O'DONNELL, Guillermo; SCHMITTER, Philippe C. Transições do regime autoritário, p. 48.
} 
Destacando a profunda incerteza quanto ao futuro que caracteriza os momentos transicionais, Francisco Weffort aproxima-se dessa tradição, ao destacar que não se trata de um receio apenas subjetivo, pois os riscos de retrocesso estão, de fato, no horizonte durante esses períodos críticos. E, "se é assim, a questão central da luta pela democracia nesta parte do mundo deve ser entendida como a de continuar o processo de transição e como consolidar a democracia" $" 120$.

Em suma, essa é uma dimensão normativa central que se pode extrair dessas análises, dado que se propõem a ser não apenas reflexões teóricas, mas também guias de ação política ofertados aos jogadores estratégicos, para que estes pudessem tomar consciência das alternativas e riscos presentes no momento histórico especial por que passavam. Nesse sentido, o objetivo maior que permeia essa literatura é evitar, a qualquer custo e acima de qualquer outra coisa, que o processo transicional seja interrompido ou que haja um retorno ao autoritarismo, receio este que pesa como uma espada de Dâmocles sobre as movimentações no jogo político ${ }^{121}$.

Essa virtualidade de um golpe, ainda que não consumada realmente, repousa como um dado fundamental para orientar as condutas dos agentes que estão à dianteira no processo de transição. E não é menor a importância teórica desse dado para os estudos considerados.

Com efeito, essa ameaça latente, mas sempre presente, desempenha uma função fundamental e bastante eficaz no jogo político. Primeiro, porque o risco de contragolpe fica sempre pendente como advertência para todos. Em segundo lugar, pois esse mesmo risco permanece como instrumento de pressão dos brandos para moderar a velocidade do processo $^{122}$.

Retomando a analogia lúdica, agora em relação ao jogo de carteado, O’Donnell caracteriza essa estratégia do grupo dos brandos como um "ás" com que estes podem contar e que consiste na ameaça à oposição de que, se esta não seguir as regras do jogo que

\footnotetext{
${ }^{120}$ WEFFORT, Francisco. Incertezas da transição na América Latina, p. 83.

121 Veja-se, por exemplo, o seguinte trecho: "Uma vez escolhida a liberalização - quaisquer que sejam as razões e qualquer que seja o grau de controle exercido pelos dirigentes - emerge um fator que pende como uma espada de Dâmocles sobre o resultado possível. Trata-se do medo de um golpe que não apenas interrompa a transição, mas imponha um retrocesso que leva a uma forma ainda mais restritiva e repressiva de governo". O’DONNELL, Guillermo; SCHMITTER, Philippe C. Transições do regime autoritário, p. 47.

122 O'DONNELL, Guillermo. Contrapontos, p. 93. Exemplo concreto disso é dado no depoimento de Paulo Sérgio Pinheiro segundo o qual, durante a transição brasileira, "quando foi publicado o Brasil Nunca Mais, quase ao mesmo tempo em que o presidente José Sarney era empossado, ouvi nos circuitos do establishment político que faltava aos promotores da investigação, Dom Paulo Evaristo Arns e ao pastor James Wright, tato político, abrir as cavernas dos vampiros logo na celebração da redemocratização". PINHEIRO, Paulo Sérgio. Esquecer é começar a morrer. In: SOARES, Inês Prado; KISHI, Sandra (Coord.). Memória e verdade, p. 12.
} 
aqueles estabelecem, eles simplesmente cancelam o jogo e retornam ao autoritário status quo ante. Somente a posteriori, depois de vencida a transição e quando é constatado que não houve um golpe por parte dos duros, essa jogada poderá ser desmascarada como uma farsa. Daí esse autor afirmar que "a despeito das forças e intenções iniciais dos brandos, sua mão no final das contas será reconhecida pelo blefe em que se transformou"123.

Interessante notar que, ainda que nunca se consume efetivamente, a mera existência virtual de um golpe é fator suficiente para produzir resultados bastante concretos nas estratégias dos atores. Aliás, ocorre o contrário: justamente por não se consumar é que essa ameaça cumpre papel tão duradouro e consistente no jogo político.

Essa situação será designada, por O’Donnell, como um temor onipresente, que contamina a estratégia dos atores políticos e confere um caráter inelutavelmente mais conservador às transições pactuadas. Para esse autor, se há uma característica comum a todos os casos analisados, trata-se precisamente do temor onipresente, no decorrer do período de transição - e com frequência tempos depois de a democracia política ter sido instalada - de que um golpe venha ser tentado e tenha sucesso.

No entanto, ele próprio lembra que, por outro lado, nenhuma das transições examinadas nos estudos empíricos chegou, efetivamente, a ser interrompida por um golpe. Daí questionar uma espécie de paradoxo que emerge dessa constatação de temer-se tanto algo tão irreal: "por que, então, este não-evento, esta possibilidade que não se concretizou recebeu tanta atenção e gerou tanta angústia?”. Logo em seguida, O’Donnell expõe sua hipótese explicativa, no sentido de que "em decorrência do fato de estarem tão obcecados com sua provável ocorrência, os atores da transição tomam medidas para prevenir um tal resultado e evitam tomar decisões que consideram passíveis de encorajá-1o" ${ }^{124}$. Ainda que seja plausível essa consideração, especialmente nos quadrantes dessa própria teoria, é impossível estimar sua validade universal como motivação determinante dos comportamentos dos agentes democratizadores em uma transição política sem uma investigação mais profunda.

De qualquer modo, aqui cabe pontuar uma contradição insolúvel nos marcos dessa subdisciplina da Ciência Política. Esses autores defendem, como visto, uma concepção de transição enquanto uma situação crítica, de estranha incerteza, por conta da suspensão momentânea e indefinida das normas e procedimentos que balizam o jogo político.

${ }^{123}$ O’DONNELL, Guillermo; SCHMITTER, Philippe C. Transições do regime autoritário, p. 49.

124 O’DONNELL, Guillermo; SCHMITTER, Philippe C. Transições do regime autoritário, p. 47. 
Nesse contexto, continuam esses pensadores, despontam a centralidade e o protagonismo das ações estratégicas dos jogadores, o fator determinante e praticamente exclusivo para os resultados que surgirão. Tais jogadores, como nunca, podem agir livremente em relação aos constrangimentos estruturais e objetivos que, em tempos normais, restringem e constrangem sua atuação. É pertinente, contudo, indagar como é possível compatibilizar essa liberdade e autodeterminação (inauditas), orientadas pela racionalidade estratégica, com esse perverso medo da regressão que, em última instância, é a emoção que efetivamente orienta os cálculos e estratégias das lideranças políticas relevantes.

Tanto é assim que se afirma, sem rodeios, que esse temor onipresente é responsável por instaurar uma situação de "dupla negatividade" 125 , pois o golpe não ocorre e, ao mesmo tempo, consegue inibir e interditar diversas ações que, na visão de alguns jogadores, poderiam ter encorajado ou contribuído para sua ocorrência. O problema e os inconvenientes de tal situação truncada são evidentes. O principal e mais notório risco consiste em alimentar-se uma paralisação pelo medo dos atores políticos engajados na transição, comprometendo, até mesmo, que se alcance um regime autenticamente democrático ${ }^{126}$.

Precisamente nesse sentido, Guillermo O’Donnell, em trecho cujas palavras vale repetir, enquadra com precisão esse dilema paradigmático que acomete os jogadores, premidos por essa ingrata escolha. Assevera que "não há prescrições seguras para percorrer o caminho que se estende entre o risco de provocar uma reação autoritária, de um lado, e o risco de alienar a maioria dos defensores potenciais da democracia, de outro" ${ }^{\text {127. }}$.

125 O’DONNELL, Guillermo; SCHMITTER, Philippe C. Transições do regime autoritário, p. 47.

${ }^{126}$ Com efeito, diante do excesso de cautela que predominou nessas democracias recém-instaladas em relação à memória do autoritarismo, conduta altamente recomendada por esses transitólogos, esses regimes, de modo geral, pouco avançaram na superação do bloco autoritário e seu legado social e institucional. O que, no calor dos acontecimentos, parecia uma ameaçadora e iminente possibilidade tornou-se, pouco tempo depois, claramente, um grande blefe que apenas contribuiu para diminuir a qualidade das transições e dos governos democráticos que se seguiram. Isso emergiu de forma bastante nítida nas análises posteriores, que, com a vantagem do distanciamento histórico, miraram retroativamente sobre esse ponto. Schmitter e Santiso afirmaram, em estudo datado do final da década de 1990, que "ao contrário dos esforços anteriores de democratização, a maior parte dos quais tendiam a falhar (especialmente nos primeiros momentos que ocorreram) dentre os 50 ou mais países que fizeram essa tentativa desde 1974, pouquíssimos regrediram manifestamente ao status quo ante autocrático. Ao invés disso, a maior parte pareceu 'condenada' a permanecer, pelo menos, formalmente democrática, mesmo se relativamente poucos até agora têm feito isso seguramente para o porto seguro do regime consolidado". No original: "unlike previous efforts at democratization, most of which tended to fail (especially the first time they were made) among the 50 or so countries that have tried since 1974, very few have regressed overtly to the autocratic status quo ante. Instead, most seem 'comdemned' to remain at least formally democratic, even if relatively few have so far made it securely to the safe haven of regime consolidation". SCHMITTER, Phillippe C.; SANTISO, Javier. Three temporal dimensions to the consolidation of democracy, p. 70.

127 O’DONNELL, Guillermo. Introdução aos casos latino-americanos. 
Em trabalho posterior desse mesmo autor, desponta então a diferenciação entre dois tipos de regressão de um regime democrático para autoritário: uma "morte rápida", via um golpe militar clássico; e uma "morte lenta", materializada por uma progressiva diminuição dos espaços existentes para o exercício do poder civil e a restrição da vigência dos direitos e garantias clássicos do constitucionalismo liberal ${ }^{128}$.

Desse modo, se os jogadores agirem demais, extrapolando as limitações impostas pelas circunstâncias, podem provocar a regressão autoritária ou a "morte rápida" da democracia; se agirem de menos, não atingirão a tão almejada democratização, condenando esse processo desencadeado a uma "morte lenta". Em outras palavras, se adotarem uma postura de "competitividade excessiva", induzem um golpe militar clássico; caso sejam acometidos por um "acordismo excessivo", caminham para o bloqueio da transição.

Daí a necessidade de calibrar um ponto médio estratégico, que posteriormente se demonstrará sempre aquém do que se desejava ou mesmo do que era, em termos objetivos, possível. Formulando de maneira mais direta, a estrutura perversa de opções que esses autores imputavam não à análise que realizavam, mas à própria realidade, impunha aos atores democráticos a inescapável escolha pelo menos pior, que, por via das dúvidas, deveria estar sempre ao lado do mais prudente ${ }^{129}$.

\subsubsection{Transições negociadas e o risco da "morte lenta" da democracia}

Essa situação dramática parece agravar-se diante dos limites que caracterizam as transições negociadas, tendo em vista as consequências legadas por esse tipo de abertura controlada dos regimes autoritários para as incipientes democracias. Nesse padrão transicional, o novo governo é maculado pelas sequelas da excessiva dose de continuísmo e de conservadorismo herdados do regime anterior, pois as efetivas reformas vão-se

\footnotetext{
${ }^{128}$ O’DONNELL, Guillermo. Transições, continuidades e alguns paradoxos, p. 44. É forçoso registrar que, nos momentos mais tensos das democratizações, a preocupação era quase exclusivamente com a "morte rápida", conferindo pouquíssima atenção à possibilidade de "morte lenta", que aparece nesse texto um pouco posterior aos escritos pioneiros.

${ }_{129}$ Para O’Donnell, durante a segunda transição, há um pacto fundamental sempre selado pelos participantes com o objetivo de delimitar o campo dos atores democráticos (antiautoritários). Esse compromisso envolve "decisões (e não decisões) que alguns interpretam como necessárias para evitar uma morte rápida do processo, enquanto outros as consideram passos para a morte lenta do mesmo". O'DONNELL, Guillermo. Transições, continuidades e alguns paradoxos, p. 48.
} 
adiando, indefinidamente, para um momento mais propício, futuro e incerto. Daí o cientista político Leonel Itaussu chamar a atenção, nesses casos, para o risco de "uma longuíssima transição que deixa para as calendas a democracia ou então desemboca numa democracia tutelar"130.

O próprio O’Donnell, em trabalho posterior, de 1988, expressou seu desencanto com as previsões otimistas iniciais, ensaiando voltar atrás na convicção de que toda cautela é sempre pouco. Ele enxergou claramente as dificuldades que as transições negociadas implicaram aos passos seguintes dos processos de democratização, que acabaram, muitas vezes, limitados a congelar um governo débil e apenas formalmente democrático assombrado pelo fantasma de uma sensação de transição mal-consumada ou feita pela metade.

Por isso esse autor passou a proclamar que

\begin{abstract}
esses caminhos serão mais prolongados e tortuosos - e até mesmo reversíveis do que supúnhamos em nossas mais cautelosas antecipações durante as lutas antiautoritárias (...) governos fracos, acossados por inúmeros problemas, internos e externos e ameaçados pelos poderosos atores autoritários que permaneceram como herança do passado (...) estas democracias fracas, incompletas e, em diversos sentidos, decepcionantes, devem ser cuidadas e defendidas dos riscos muito reais - de uma regressão autoritária. O que não está claro é o que é e que não é, em cada circunstância, fazer o jogo dessa regressão ${ }^{131}$.
\end{abstract}

Verifica-se, portanto, que esses autores diagnosticam, com considerável lucidez, os inconvenientes que decorrem do formato ideal de transição que defendem. Contudo, a despeito de elaborar essa questão com clareza, demonstrando ter plena consciência das consequências limitadoras dessa estratégia focada na ação conciliadora dos brandos ${ }^{132}$, essa tradição não oferece uma resposta satisfatória nesse particular. Por receio de pecar

${ }^{130}$ ALMEIDA, Leonel Itaussu de. Golbery revisitado: da abertura controlada à democracia tutelada. In: MOISÉS, José Álvaro; ALBUQUERQUE, José A. Guilhon (Org.). Dilemas da consolidação da democracia. Rio de Janeiro: Paz e Terra, 1989.

${ }^{131}$ O'DONNELL, Guillermo. Transições, continuidades e alguns paradoxos, p. 42. Vê-se, de certo modo, contemporizada a ameaça de uma morte rápida, ainda que presente. E lança, nesse mesmo texto, ao final, a necessidade de uma revisão desses postulados, ainda que não aprofunde essa mudança de percepção. Em suas palavras, "parece-me que chegou a hora de revisar essas premissas e opiniões. Obviamente, não se trata do simplismo de girar cento e oitenta graus e descobrir agora que o segundo grupo de casos [de transições pactuadas] é o que na verdade apresenta maiores dificuldades para a consolidação e eventualmente para a própria sobrevivência da democracia (....) a análise comparativa é um instrumento útil, porém não é o meio para estabelecer o que é 'melhor' ou 'pior' (...) trata-se de examinar a contrapartida de algumas vantagens (reais e aparentes) para compor uma visão mais adequada das dificuldades enfrentadas pela consolidação democrática, diferentes das de outros casos porém também enormes" (p. 58).

${ }_{132}$ Mencione-se, por exemplo, esse trecho de O'Donnell: "mas como podem os que mais querem pressionar na direção democratizante evitar o golpe, sem cair na parálise provocada pelo medo e portanto inibir os passos seguintes no caminho da transição?". O'DONNELL, Guillermo; SCHMITTER, Philippe C. Transições do regime autoritário, p. 48. Para Przeworski, mais assertivo nesse aspecto, "as transições negociadas esbarram num dilema: a democracia política é viável ao custo de restringir as transformações sociais e econômicas". PRZEWORSKI, Adam. Amas a incerteza e serás democrático, p. 46. 
pelo excesso, que tenderia a provocar a temida regressão autoritária, a recomendação que prevalece nesses escritos é sempre pela prudência e pelo gradualismo da mudança política $^{133}$.

A opção de permitir uma radicalização do processo transicional, deixando os demais atores livres em sua movimentação ou avançando com determinação nos campos econômico e social, sequer é cogitada como viável. Como visto, o cânone básico dessa teoria da transição é que os brandos devem pactuar com os duros, preservando seus interesses fundamentais, e utilizar o argumento da ameaça autoritária com os radicais da oposição, mantendo sob controle o processo.

Todos os demais atores, se prudentes e consequentes forem, deverão se orientar por uma "ética de responsabilidade", segundo a qual não basta fazer o que se julga correto; é preciso, também, refletir sobre os efeitos que determinada conduta pode gerar. Ética esta, aliás, que os próprios cientistas políticos, na condição de teóricos, pareceram ter introjetado algo inconscientemente.

\subsubsection{Os interesses fundamentais do bloco autoritário}

Assim, em última instância, a questão essencial que determinará a dinâmica concreta e a forma de articulação entre as figuras dos jogadores, bem como os limites e brechas da transição, são os interesses fundamentais dos membros do regime autoritário. Ao fim das diversas interações, são estes que prevalecerão sobre os demais interesses e expectativas em jogo, pois a coalizão governante detém uma vantagem significativa: controla, de maneira mais ou menos tranquila, a iniciativa política, a máquina do Estado e os aparatos de poder.

\footnotetext{
${ }^{133}$ Segundo O’Donnell, que manteve esse entendimento inclusive no referido texto de 1988, “este é o núcleo do problema estratégico dos atores democratizantes: por um lado, evitar essas regressões e por outro empurrar o processo de maneira tal que - embora a ritmos oscilantes e com numerosas incertezas - ele avance até à consolidação da democracia”. O’DONNELL, Guillermo. Transições, continuidades e alguns paradoxos, p. 44. Por isso a criteriosa crítica de Vitullo, que considera que "há uma marcada exaltação, nesses escritos, da necessidade de cautela, de moderação e de celebração de compromissos e das vantagens de se fazer sentir aos brandos do regime que ainda contam com capacidade de iniciativa política - tudo o qual comporta, segundo o nosso ponto de vista, uma inadmissível claudicação. Que tipo de democracia há de se levantar sobre pilares tão débeis". VITULLO, Gabriel Eduardo. Transitologia, consolidologia e democracia na América Latina, p. 58.
} 
Daí o momento maquiavelano da estratégia dos brandos ser, justamente, o ato de “convencer a si mesmos e aos outros que os 'interesses fundamentais' da aliança do Estado Burocrático-Autoritário não ficarão menos resguardados - e, a longo prazo, até mais - do que ficariam com a alternativa continuísta dos duros" ${ }^{\text {"134 }}$. Como na base de sustentação desse tipo de Estado autoritário estão, basicamente, as Forças Armadas e as classes dominantes, são os interesses desses setores que serão alçados à condição de interesses fundamentais e preponderantes no momento da transição.

Mas quais seriam esses interesses fundamentais? O’Donnell afirma que é impossível responder, a priori, no que consistem os interesses fundamentais que são intocáveis durante as transições. Primeiro, porque eles não são determináveis fora do processo da transição em si e, além disso, por haver uma redefinição dinâmica desses interesses durante o período da transição ${ }^{135}$.

Esse autor sustenta, no entanto, que, no início desses processos de mudança, os interesses costumam ser definidos de modo extremamente amplo e com maior grau de liberdade, tanto pela grande burguesia como pelas Forças Armadas. Na medida em que o processo avança e a correlação de forças se modifica, tais interesses tendem a ser redefinidos, com uma restrição às posições inicialmente assumidas, dadas as concessões necessárias a cada conjuntura.

No entanto, ainda segundo O’Donnell, apesar de haver uma elasticidade para a mudança de posições por parte dos jogadores estratégicos, há determinados limites. Por exemplo, no que diz respeito às Forças Armadas, o ponto não negociável parece o relacionado com a alteração da hierarquia de disciplina, em especial a que separa oficiais de suboficiais e soldados ${ }^{136}$. Outro ponto sensível, de maior relevância para a presente dissertação, é o processamento penal dos membros do regime autoritário que praticaram crimes de lesa-humanidade.

Explicados estes aspectos marcantes dessa teoria das transições, torna-se possível, agora, examinar a maneira como algumas questões particulares, que seriam posteriormente sistematizadas e desenvolvidas em um conceito designado por de justiça de transição, são encaradas nesse referencial teórico.

\footnotetext{
134 O’DONNELL, Guillermo. Contrapontos, p. 83.

135 Essa dinamicidade é da própria definição da transição, pois ela envolve modificações contínuas, senão lineares e irreversíveis, tanto nas relações de força entre diversos atores, quanto nas concepções desses com relação aos seus próprios interesses. O’DONNELL, Guillermo; SCHMITTER, Philippe C. Transições do regime autoritário, p. 54.

136 O’DONNELL, Guillermo. Contrapontos, p. 83.
} 


\subsection{A justiça como problema e fonte de instabilidade}

A dimensão prescritiva dessa primeira geração de estudiosos da transição é bastante evidente, como foi tratado. O imperativo de evitar um novo golpe subjuga todas as demais reivindicações que possam surgir nas transições. Nesse contexto, vale questionar qual o papel e o estatuto reservado às demandas por justiça diluídas na sociedade.

Nesses momentos particularmente conturbados e incertos, é natural que os atores políticos, após décadas de repressão e falta de liberdades, transbordem, com elevada intensidade e pressa, suas demandas há tempos represadas. Daí, inclusive, a enorme e especial dificuldade de hierarquizarem-se em uma agenda política ou de governabilidade reclamos tão numerosos, tão impacientes e há tanto tempo postergados ${ }^{137}$.

Comprovação disso é que esse cenário acaba acentuando a tendência a um certo imediatismo ("now-ism"), pois todas as demandas por justiça têm amplo grau de legitimidade e, portanto, de urgência. Mas, na visão desses autores, essa perspectiva mais radical, sustentada normalmente por atores mais outsiders, não é bem vista e deve ser evitada para que se consume a transição negociada que propugnam ${ }^{138}$.

Essa será apontada, posteriormente, como uma das grandes insuficiências dessas teorias das transições. Eduardo Gonzalez Cueva, de forma perspicaz, observa que as respostas sobre o problema de como se enfrentar o legado das injustiças cometidas pelos regimes autoritários, por esses autores, são pouco conclusivas. Isso porque sempre "partem de um marco teórico, como foi visto, que pressupõe o intercâmbio político como uma forma de ação essencialmente estratégica entre atores impulsionados por motivos materiais

\footnotetext{
${ }^{137}$ Merwe afirma que "demandas por justiça durante as transições vêm de muitos lugares. As mais imediatas são as demandas dos sobreviventes e das famílias das vítimas". No original: "demands for justice during transitions come from many quarters. Most immediate are the demands from survivors and the families of victims". MERWE, Hugo Van Der. Delivering justice during transition: research challenges. In: BAXTER, Victoria; CHAPMAN, Audrey R. (Ed.). Assessing the impact of transitional justice. Washington DC: United States Institute of Peace, 2009. p. 115-14. p. 116.

138 Por isso a afirmação de Sanguinetti: “acabar com o que eu chamo de 'imediatismo' é também uma das maiores tarefas psicológicas. Durante a transição, há uma tendência de que todas as reivindicações se tornem urgentes (...). O 'imediatismo' é bastante compreensível, é claro, mas a energia que ele mobiliza deve ser aproveitada se um deslize ao conflito e à vingança quer ser evitado". No original: "the quelling of what I call 'now-ism' is also a major psychological task. During times of transition, there is a tendency for all claims to become urgent (...) 'Now-ism' is quite understandable, of course, but the energy it signals must be harnessed if a lapse into conflict and revenge is to be avoid". SANGUINETTI, Julio María. Present at transition, p. 56.
} 
em benefício próprio. Essa noção impede a possibilidade de compreender comportamentos não estratégicos, baseados em valores pouco flexíveis, por parte dos principais agentes"139.

Em outras palavras, é fato que a teoria das transições adota um modelo que passa, centralmente, pela pressuposição de que os atores estão sempre preocupados, exclusivamente, com a obtenção do poder político a fim de levar a cabo programas de governo possíveis em momentos de governabilidade crítica, por conta das condições sociais, econômicas e institucionais que vigoram durante as transições.

Por isso, esse autor sustenta que "as teorias das transições têm um ponto cego na questão da justiça transicional: a possibilidade de que existam agentes 'radicais' cuja radicalidade esteja baseada em princípios tais que lhes impedem de adotar uma racionalidade estratégica propícia à negociação. Essa opção teórica resulta em conclusões débeis e pouca capacidade prescritiva" ${ }^{140}$.

Com efeito, para os radicais normalmente considerados pela transitologia, cujos representantes mais notáveis são os socialistas que almejam ir além dos limites da democracia formal, as derrotas do presente seriam sempre contemporizadas pela expectativa de que, no futuro, uma revolução viesse a ocorrer.

Outra situação completamente distinta, no entanto, é a dos familiares dos desaparecidos políticos, figura amplamente disseminada nas ditaduras do Cone Sul. Essa massificação de casos, produzidos em larga escala pela forma de repressão política adotada pelas ditaduras, aliada à justeza de uma reivindicação tão incontestada, acabou conferindo representatividade e força não previstas a esses atores, solenemente ignorados na literatura analisada. Mas, a história testemunhou, logo depois da queda das ditaduras, o protagonismo desses atores políticos para a democratização efetiva desses países.

\footnotetext{
${ }^{139}$ No original: “(...) respuestas poco concluyentes sobre el problema de cómo enfrentarse el legado de las injusticias cometidas por los regímenes autoritarios (...) parte de un marco teórico que presupone el intercambio político como una forma de acción esencialmente estratégica entre agentes impulsados por motivos materiales de beneficio propio. Esta noción impide la posibilidad de comprender comportamientos no estratégicos, basados en valores poco flexibles, de parte de los principales agentes". CUEVA, Eduardo González. Perspectivas teóricas sobre la justicia transicional. Disponível em: $<$ http://www.cnrr.org.co/interior_otros/pdf/justran/Gonzalez_Cueva.pdf $>$. Acesso em: 20 dez. 2011. p. 18.

${ }^{140}$ No original: "la teoría de las transiciones, pues, tiene un punto ciego en la cuestión de la justicia transicional: la posibilidad de que existan agentes 'radicales' cuya radicalidade esté basada en principios tales que les impidan una racionalidad estratégica propicia a la negociación. Esta opción teórica resulta en conclusiones débiles y poca capacidad prescriptiva". CUEVA, Eduardo González. Perspectivas teóricas sobre la justicia transicional, p. 20. Esse autor ainda ressalta um dado importante. Quando essa geração de cientistas políticos dedicados ao problema transicionais escreveu suas principais obras, no fim da década de 1980, "tinham no momento (...) tão somente a experiência inicial dos julgamentos das juntas militares argentinas, da ditadura de García Meza na Bolívia e da junta dos coronéis na Grécia. No original: "tenían en el momento en que escribieron su libro tan sólo la experiencia inicial de los juicios a las juntas militares argentinas, a la dictadura de García Meza en Bolivia y a la junta de los coroneles en Grecia” (p. 19).
} 
Nesses casos, é desnecessário frisar que o fator temporal pesa com maior dramaticidade. Basicamente, porque a idade avançada e os longos anos de busca por seus entes queridos não são compatíveis com os cálculos estratégicos de um projeto político racionalmente concebido. Esses familiares desejam notícias imediatas sobre o paradeiro dos que foram desaparecidos e, nesse sentido, não há a menor disposição em negociar saídas intermediárias ou conciliadas que impliquem o adiamento da questão para um futuro eventual e incerto.

Ou seja, "é evidente que as reivindicações das vítimas de violações de direitos humanos diferem essencialmente de temas de justiça econômica ou do acesso a segmentos do poder político" ${ }^{141}$. Esse parece ser um aspecto completamente ignorado por esses teóricos, que não conferem o caráter político que as demandas de direitos humanos acabaram assumindo, muitas vezes tão marcante quanto aquelas clássicas reivindicações de justiça substantiva.

Em geral, apenas admitiram a legitimidade da impaciência desses setores, que sempre acabam gerando conflitos de difícil solução nesses contextos. Essa tensão, com diferentes graus de intensidade, esteve sempre presente nas transições ocorridas nos países do Cone Sul. Um misto sentimental de esperança, medo e impaciência descrevem bem o estado de espírito dos atores engajados na oposição democratizadora. Daí o depoimento de um dos principais atores individuais da transição uruguaia, o ex-presidente Julio María Sanguinetti, no sentido de que "a transição requer a gestão constante de duas emoções: medo e impaciência. O período transicional cria expectativas. O renascimento da liberdade pode desencadear forças novas ou há muito adormecidas, todas as quais geram emoções muito fortes. Os líderes depostos temem que eles possam virar alvos de retaliação (...). Ao mesmo tempo, há impaciência daqueles que chegaram ao poder"142.

No entanto, o medo e a impaciência não recebem a mesma compreensão nessa tradição, incapaz de dar conta da complexidade dessa situação. Enquanto o primeiro deve ser seriamente levado em consideração, para que a mudança transcorra o mais pacificamente possível, a impaciência e o senso de urgência dos atores políticos diretamente afetados pela violência política sequer são considerados nas motivações tão

\footnotetext{
${ }^{141}$ No original: "es evidente que los reclamos de las víctimas de violaciones de derechos humanos difieren esencialmente de temas de justicia económica o de acceso a segmentos del poder político". CUEVA, Eduardo González. Perspectivas teóricas sobre la justicia transicional, p. 19 e 20.

${ }^{142}$ No original: "a transition requires the constant management of two emotions: fear and impatience. Transition periods create expectations. The rebirth of libert can unleash new or long-dormant forces, all of which generate very strong emotions. The deposed leaders fear that they may become targets of retaliation (...). At the same time, there is the impatience of those who have come to power". SANGUINETTI, Julio María. Present at transition, p. 55.
} 
racionais que informam os jogos de poder, dado o potencial desagregador que esses sentimentos carregam. São tidas, portanto, como expectativas irrealistas e inoportunas.

Para essa literatura, a justiça em relação ao passado nunca foi o mote principal, pois significava reavivar - ou mesmo atirar luz sobre - conflitos que, caso retomados abertamente, impediriam uma efetiva reconciliação por meio de um acordo político entre os jogadores tidos como relevantes. De algum modo, atender aos reclamos de setores particulares, no caso dos familiares dos desaparecidos políticos, poderia comprometer a transição, algo de interesse mais universal.

Não por outra razão, a esses autores, importam primordialmente os interesses fundamentais da coalizão governante e dos setores moderados, em detrimento de todos os demais desejos e expectativas dos agentes democratizadores menos alinhados. Isso porque os militares que perpetraram esses crimes ${ }^{143}$ e que, normalmente, têm algum tipo de influência política nos regimes autoritários poderiam sentir-se ameaçados por esse tipo de tendências revanchistas, tendendo a formar um bloco que se oponha e coloque em xeque a própria transição. Quando não puderem boicotá-la inteiramente, os militares vão impor limites às mudanças e consagrar determinadas garantias de que o "passado não será desenterrado" ${ }^{\prime 144}$.

Tanto que esses autores não vacilavam em assumir que os limites impostos por uma tutela militar, que eventualmente subsista, deveriam ser aceitos, tudo em nome da marcha adiante da transição e da consolidação democráticas. Nesse sentido, Schmitter afirma que "se um governo tem a intenção de não provocar um golpe e não correr o risco de repressão, ele pode engolir sua indignação moral e seus ideais democráticos e aceitar os limites postos pela tutela militar"145.

Desse modo, resta claro que essa literatura não ignorava os problemas relativos a uma transição justa e tampouco o discurso dos direitos humanos, ainda que, sob viés específico das transições políticas, esse discurso fosse bastante precário e incipiente ${ }^{146}$.

\footnotetext{
${ }^{143}$ Ainda que seja comum referir-se nominalmente aos militares quando o assunto são as violações aos direitos humanos e a repressão política nos regimes autoritários latino-americanos, vale registrar, como lembrava há tempos O’Donnell, que "em nenhum dos casos os militares intervieram sem um apoio civil significativo e ativo apoio civil significativo e ativo". O’DONNELL, Guillermo; SCHMITTER, Philippe C. Transições do regime autoritário, p. 59.

${ }^{144}$ Nas palavras de O’Donnell e Schmitter, “onde não podem evitar a transição, esforçam-se por obter garantias efetivas de que sob nenhuma circunstância 'o passado vai ser desenterrado'”. O'DONNELL, Guillermo; SCHMITTER, Philippe C. Transições do regime autoritário, p. 55.

${ }^{145}$ No original: "if a government is intent on not provoking a coup and not risking repression, it may swallow its moral outrage and its democractic ideals and accept the limits set by military tutelage". PRZEWORSKI, Adam. Democracy and Market, p. 76.

${ }^{146}$ A colocação de Huntington, a seguir transcrita, é exemplar dessa consciência, ao apontar, com certa clareza, as linhas de força que colocaram os direitos humanos na agenda política internacional, analisando as
} 
Desde seus primeiros escritos, esses autores já percebiam os reclamos por justiça por parte das vítimas e de seus familiares, que na maior parte das vezes se afirmaram publicamente ainda antes da queda dos regimes autoritários. No entanto, é fato incontestável que essa problemática não recebeu a atenção que merecia.

\title{
2.2.1 As violações aos direitos humanos e os interesses fundamentais
}

Nesse sentido, concretamente, emerge um ponto crítico nessas análises, que diz respeito a como lidar com o legado de violações de direitos humanos que foram perpetradas pelos agentes dos regimes autoritários. O’Donnell, argentino que teve de exilar-se e conhecedor da política sistemática de desaparecimentos forçados que foi implementada em seu país, já admitia esse nó górdio das transições latino-americanas e, por consequência, de uma teoria que se debruce sobre elas.

Reconhecia ele que o "problema que mais contamina o clima ético e político da transição e que, em função das reverberações que provoca nas forças armadas, alimenta os maiores temores de uma regressão brutal" é "o problema de lidar com os atos repressivos perpetrados no decorrer do regime autoritário"147.

Em outra passagem bastante significativa, em que se dedicava à dimensão da contestação articulada em torno de questões militares, Stepan sustentava que

\begin{abstract}
num regime em processo de democratização, tal grau de contestação é profundamente afetado pelo nível de intensidade da disputa ou pela substância do acordo que foi alcançado entre os militares e o governo que assume o poder, em relação a uma série de questões fundamentais. Neste sentido, uma área de grande potencialidade de conflito será a maneira pela qual o novo regime trata o legado das violações dos direitos humanos cometidas pelo regime autoritário anterior $^{148}$.
\end{abstract}

razões da emergência de um olhar de reprovação aos regimes autoritários recentes, o que não ocorria até então: "Tais ações pelos governos autoritários do final do século XX não diferiram muito das praticadas pelos regimes autoritários anteriores. Tal comportamento tornou-se uma questão central em suas sociedades, em grande parte devido ao desenvolvimento da preocupação global com os direitos humanos na década de 70 . Isso se manifestou na legislação sobre os direitos humanos no Congresso dos Estados Unidos, no surgimento de organizações de direitos humanos, no papel mais ativo das organizações intergovernamentais de defesa dos direitos humanos, e nas ações do governo de Carter, que colocou a questão dos direitos humanos na agenda mundial. Como resultado, quando os governos democráticos chegavam ao poder, não podiam deixar de enfrentar as violações dos direitos humanos pelos regimes que os tinham antecedido". HUNTINGTON, Samuel p. A terceira onda, p. 210.

147 O'DONNELL, Guillermo; SCHMITTER, Philippe C. Transições do regime autoritário, p. 54.

148 STEPAN, Alfred. As prerrogativas militares nos regimes pós-autoritários: Brasil, Argentina, Uruguai e Espanha. In: . (Org.). Democratizando o Brasil. Rio de Janeiro: Paz e Terra, 1988. p. 522. Ainda nesse texto, Stepan destaca que "a questão sobre o passado refere-se ao tratamento a ser dado aos infratores dos direitos humanos que continuam em cargos do aparelho de Estado" (p. 539). 
Identificavam, desse modo, já àquela época em que escreveram, que essa questão das violações dos direitos humanos se anunciava como uma das principais possíveis fontes de tensão no processo transicional.

Contudo, esse é um problema que, a despeito de formulado adequadamente, não encontrou uma resposta definitiva ou uma solução satisfatória nos quadrantes originais dessa tradição. Constatar a gravidade e a premência de uma questão no âmbito de uma teoria não implica, necessariamente, dar um tratamento analítico adequado à mesma.

Isso porque, ainda que reconhecessem a legitimidade e a justeza das reivindicações daqueles que foram diretamente afetados pelos atos de violência durante as ditaduras, essa teoria da transição, cujo eixo organizador passa inevitavelmente pela continuidade de um processo de evolução linear e voltado apenas ao futuro, não provê o espaço adequado para essa questão de ordem ética e moral.

Isso leva a que esse conjunto de reflexões termine priorizando, de maneira pouco mediada, apenas uma das dimensões presentes nas transições, que é o desafio de sua continuidade. As demais questões relativas à reparação e à justiça para aqueles que foram afetados são levadas em conta de modo bastante residual e não logram o reconhecimento que lhes seria reservado nos anos mais recentes ${ }^{149}$.

Quanto a esse aspecto, é preciso ter tranquilidade para ressaltar que essa crítica decorre de uma constatação elementar, pois justiça deve ser feita a essa geração de transitólogos. Não se trata de cobrar desses autores algo que estava no horizonte daquela época histórica ou mesmo que não quiseram problematizar. Ainda que não tenham dispensado muita atenção a esses dilemas fundados na pretensão de justiça, sempre vista como fator desestabilizador e desconsolidador da democracia, incorporaram essa variável nas análises feitas, atribuindo-lhe, contudo, um papel submisso bastante claro.

\footnotetext{
149 Essa deficiência é bem apontada por um dos cientistas políticos integrante dessa tradição em texto ulterior: "então, ao invés de criar expectativas prometendo corrigir os erros do passado, a ênfase tem sido, geralmente, minimizar expectativas 'irrealistas', conciliar interesses antes antagônicos e reduzir os riscos envolvidos a cada vez que um governo eleito dá vez ao outro. Isso não quer dizer que todas as queixas envolvendo maus tratos passados deixaram de ser atendidas, como demonstra a gama de políticas sobre 'verdade e justiça' em relação às violações de direitos humanos praticadas no passado. Mas, no conjunto, e comparada à história recente da democracia na região, as novas democracias têm sido moderadas, pessimistas e desmobilizadoras". No original: "so instead of raising expectations by promising to right past wrongs, the emphasis has generally been to minimize 'unrealistic' expectations, conciliate formerly antagonistic interests, and to reduce the stakes involved each time an elected government gives away to another. This is not to say that all grievances concerning past mistreatments have gone unattended, as the range of 'truth and justice' policies for past human rights violations show. But on the whole, and compared to the earlier history of democracy in the region, the new democracies have been low key, downbeat, and demobilizing". WHITEHEAD, Laurence. Latin America: a new interpretation. New York: Palgrave Macmillan, 2006. p. 203/204.
} 
Aliás, é inteiramente coerente com o recorte analítico adotado nessa literatura que essa questão da justiça nos períodos de exceção então vividos permanecesse negligenciada a uma posição secundária, pois o foco principal desses trabalhos era garantir a continuidade plena dos processos transicionais e evitar o ressurgimento de formas autoritárias de governo. Esse era o principal risco a ser evitado segundo essa visão e, assumida essa premissa, insistentemente proclamada por esses autores, dificilmente se chegaria a conclusões diversas das apresentadas.

Com efeito, o norte que orienta, pratica e teoricamente, essa literatura no campo da Ciência Política deve ser compreendido à luz do contexto histórico então vivido nos países da América Latina e das leituras de conjunturas desses estudiosos, segundo as quais as transições deveriam avançar de maneira gradual e segura.

Essa é uma escolha consciente e consequente por parte desses autores, que tem como pano de fundo, precisamente, a dificuldade de conciliarem-se dois imperativos de caráter normativo e de pouca flexibilidade: por um lado, as demandas por justiça e reparação das vítimas e, por outro, o dever de levar adiante, sem solavancos e a qualquer custo, o caminho que conduzirá a transição a uma democracia. A essa dificuldade, não encontraram uma solução satisfatória, pela unilateralidade do raciocínio que adotaram.

Vale também lembrar que, diante desse dilema, esses cientistas políticos não se pretendiam apenas teóricos indiferentes aos rumos da transição, mas, sobretudo, como agentes políticos que poderiam contribuir para iluminar os caminhos que pudessem levar ao melhor resultado ${ }^{150}$. Ainda que o papel protagônico estivesse reservado aos agentes políticos e suas estratégicas nos jogos de poder, esses intelectuais, sob o forte argumento da excepcionalidade da situação vivida, não se limitaram a fazer uma leitura imparcial.

Ao contrário, responsabilizaram-se diretamente e tomaram parte nos diversos conflitos e polarizações que emergiram naquele período. Aportaram, assim, suas opiniões de prestígio às disputas travadas publicamente em torno da transição nesses diversos países, contribuindo significativamente para o desenlace desses processos políticos e, do mesmo modo, para os limites impostos, na medida em que lhes conferiram certo grau de racionalização teórica e legitimação política.

Nessa linha, para a articulação específica que realizavam entre as demandas de justiça e as restrições colocadas aos atores políticos que negociam o pacto durante a

\footnotetext{
${ }^{150}$ Esse fato de esses analistas se pretenderem "conselheiros do príncipe" será apontado, por alguns autores, como uma explicação para a "perda de capacidade crítica resultante das teorias da transitologia e da democratização hegemônicas na Ciência Política. Muitas análises originadas nesses moldes teóricos realmente deixaram de ser críticos, para converterem-se em prescrições para ação e para o desenho de políticas governamentais". VITULLO, Gabriel Eduardo. Transitologia, consolidologia e democracia na América Latina, p. 58.
} 
transição, também cumpre papel importante o ideal compartilhado por esses autores, segundo o qual as transições pactuadas são as mais adequadas e que os acordos políticos que as originam têm autonomia frente a determinações de outras ordens, inclusive aquelas emanadas de espaços normativos internacionais, que já caminhavam no sentido de promover e proteger os direitos fundamentais dos cidadãos perante seus próprios Estados.

Tanto é assim que, mesmo quando avaliam os reclamos por justiça, fazem-no sob um ótica utilitarista, aferindo como e em que medida a punição das violações de direitos humanos terão força dissuasiva ou preventiva frente a novas violações. Ou seja, interpelam essas medidas para verificar se contribuem ou não para a construção da democracia, pouco importando, em si mesmas, as aspirações das vítimas. Estas podem, até mesmo, serem desfuncionais, provocando um agravamento do nível de repressão de uma nova recaída autoritária.

Nesse sentido, veja-se a ponderação entre esses princípios que Schmitter elabora. Ao cogitar uma relação de causalidade entre a punição das violações aos direitos humanos e o processo de democratização, esse autor atrela um eventual efeito dissuatório dessa medida sobre os militares a uma certeza de que, uma vez fracassada, o novo golpe dado por estes será ainda mais duro. Sustenta que:

\begin{abstract}
um argumento para punir as violações de direitos humanos é que o efeito da punição é dissuasivo: os militares pensarão duas vezes antes de pisar ('na bola') novamente porque eles sabem que, uma vez fora do poder, serão punidos. Isso pode ser verdade, mas se esse argumento é válido, isso também implica que se os militares não forem dissuadidos pela ameaça de punição, vão ser menos propensos a abandonar o poder por causa dessa ameaça. Assim, as imposições de controle civil podem reduzir a probabilidade de um golpe, mas aumentam a probabilidade condicional de que, uma vez que ocorrer, o golpe será altamente repressivo $^{151}$.
\end{abstract}

$\mathrm{Ou}$ seja, reitera-se o discurso do medo e da ameaça como argumentos para orientar o tratamento a ser conferido às violações de direitos humanos. Fica claro que a regra geral é por não questionar os interesses fundamentais da coalizão governante, ainda que, em hipóteses específicas e bem determinadas, possa haver uma relativização prudente que, na condição de exceção, apenas deve confirmar a regra.

\footnotetext{
151 No original: "one argument for punishing violations of human rights is that the effect of punishment is dissuasive: The military will think twice before stepping in again because they know that once out of power they will be punished. That may be true, but if this argument is valid, it also implies that is the military are not deterred by the threat of punishment from stepping in, it will be less likely to give up power because of this threat. Thus, impositions of civilian control may lower the probability of a coup but increase the conditional probability that, once it occurs, the coup will be highly repressive, a golpe duro". PRZEWORSKI, Adam. Democracy and Market, p. 75 e 76.
} 


\subsubsection{Então quando julgar?}

Para Guillermo O’Donnell, uma primeira questão importante a apurar para saber como tratar o legado de violações de direitos humanos herdados de um regime autoritário é saber se as forças armadas como tal foram ou não diretamente responsáveis pela maioria dos atos de repressão. Se não tiveram um envolvimento institucional relevante, não haveria sentido em envolvê-las em um acerto de contas com os atos cometidos por seus membros no passado $^{152}$.

Outro aspecto que deve ser considerado, ainda em sua visão, é o que designa como "a magnitude absoluta e a 'qualidade' da repressão física", entendidas como "o grau em que foram cometidos atos particularmente repulsivos, e o grau em que pessoas claramente inocentes vieram a sofrer" ${ }^{\prime 153}$. Assim, se os sofrimentos impingidos à sociedade e aos indivíduos particularmente considerados não atingiram níveis elevados e insuportáveis, ainda que não detalhe como são as medidas que compõem essas escalas de sofrimentos, esse é um fato dissuasório da ideia de punição aos perpetradores das violências.

Esse autor ainda ressalta que é preciso ter em conta que a passagem do tempo costuma atenuar as memórias mais amargas tanto dos atos do regime quanto dos atos dos oposicionistas, estes normalmente invocados no discurso oficial dos regimes autoritários para justificar as atrocidades cometidas como políticas de Estado.

Diante dessas ponderações, evidentemente também postas em uma ótica utilitarista estrita, subjugada ao imperativo de preservação do processo transicional, "uma política de clemência parece mais viável e menos perigosa para a democratização nos países em que a repressão foi, desde o início, menos brutal e ampla ou onde sua ocorrência sucedeu há muito tempo"154.

Por sua vez, nesse mesmo sentido, Samuel Huntington elabora uma verdadeira receita de como lidar com os legados de violações de direitos humanos no tópico intitulado "guias de ação para democratizadores: o tratamento dos crimes autoritários". Esse autor sugere os seguintes procedimentos e medidas - bastantes pragmáticos e utilitaristas - à questão da justiça na transição política:

\footnotetext{
152 O’DONNELL, Guillermo; SCHMITTER, Philippe C. Transições do regime autoritário, p. 54. 
1. Se ocorreu transformação ou transtituição, não tente processar os funcionários autoritários por violações de direitos humanos. Os custos políticos de tais esforços serão maiores do que os ganhos morais; 2. Se ocorreu substituição e se você achar que é moralmente e politicamente desejável, processe rapidamente os líderes do regime autoritário (no máximo um ano após assumir o poder), deixando claro que não vai processar os de nível médio e baixo; 3 . Descubra um meio de chegar a um relatório público completo e desapaixonado de como e por que os crimes foram cometidos; 4. Reconheça que na questão processar e punir vs. perdoar e esquecer, cada alternativa apresenta graves problemas, e que o caminho menos insatisfatório será: não processe, não puna não perdoe e, acima de tudo, não esqueça ${ }^{155}$.

Em outras palavras, nem todas as situações merecem - e, especialmente, comportam - uma política deliberada orientada à persecução penal dos crimes de violação a direitos humanos praticados em um contexto autoritário. Isso significa que, em si mesmo, esse imperativo de atender aos reclamos de justiça das vítimas, recuperando o passado traumático, não carrega um valor intrínseco, mas pode - e até deve - ser mobilizado em circunstâncias excepcionais, marcadas por violências extremas, nas quais essas medidas poderão até demonstrar alguma funcionalidade para regularizar as instituições democráticas.

Aqui, mais uma vez, trata-se de uma avaliação racional entre as diversas variáveis, que devem ser sopesadas diante da situação concreta transicional e dos dilemas aí postos. Contudo, de acordo com essa visão, esse cálculo entre as vantagens e as desvantagens da adoção de medidas de justiça, sempre à luz de um determinado contexto, deve ser cuidadosamente realizado.

Fundamentalmente, porque ele é necessário para que não se comprometa o êxito da transição e para que não se revivam conflitos a partir de atos de violência razoavelmente toleráveis que seriam, em algum momento, naturalmente esquecidas pelo baixo grau de impacto social que tiveram. As energias da transição, assim, não poderiam ser consumidas com algo que não contribuísse, efetivamente, para a consecução do projeto político liberalizante.

Por outro lado, há casos agudos em que o esquecimento do passado é inaceitável e as demandas por justiça são impostergáveis, tendo em vista um patamar ético mínimo e irrenunciável. Um exemplo de caso extremo, com essas características, para o próprio O’Donnell, é o caso da sua terra natal, a Argentina. Ele chegará a afirmar, claramente, que

\footnotetext{
${ }^{155}$ De algum modo, ainda que genericamente, esse autor menciona, além do direito à justiça, também discutido pelos outros autores, o direito à verdade ("relatório público completo e desapaixonado de como e por que os crimes foram cometidos). Essas são duas dimensões que, mais sistematizadas e inter-relacionadas entre si, serão centrais para a construção do conceito de justiça de transição, como se verá adiante. HUNTINGTON, Samuel p. A terceira onda, p. 228.
} 
“a moral não é mais tão flexível e silenciosa como antes à época em que Machiavel escreveu suas oportunas máximas de prudência política" ${ }^{" 156}$.

Daí esse autor afirmar, em excerto longo a seguir reproduzido, diante de algo tido como uma indignação ética da maior parte de um povo, a pertinência de não ignorar os horrores "por demais indescritíveis":

\begin{abstract}
os atores presentes à transição devem satisfazer não apenas interesses vitais como ideais vitais - padrões relativos ao que se considere decente e justo. $\mathrm{O}$ consenso entre os líderes políticos da transição em torno do esquecimento do passado pode mostrar-se eticamente inaceitável aos olhos da maioria da população. Todos os nossos casos demonstram a imensa dificuldade que esse dilema aporta; nenhum deles fornece para ele uma solução satisfatória. Mas mesmo sob as piores circunstâncias - ocorrência intensa e recente, e cumplicidade ampla e profunda por parte dos militares, como ocorreu na Argentina contemporânea - acreditamos que a pior das soluções seria a tentativa de ignorar a questão. Alguns horrores são por demais indescritíveis e recentes para permitir que os atores os ignorem ${ }^{157}$.
\end{abstract}

Reconhece-se, assim, não haver solução satisfatória no horizonte para essa delicada questão. A opinião de O’Donnell, ao tratar desse caso particular, vai diretamente de encontro ao princípio geral de não tumultuar o processo transicional com questões candentes do passado. Chega a pontuar que uma operação de acobertamento tem como custo principal "reforçar o sentimento de impunidade e de imunidade das forças armadas, especialmente dos seus elementos mais sinistros"158.

Além disso, um segundo custo, para esse autor, é mais difuso, mas não menos crucial. Trata-se da impossibilidade de uma sociedade estabelecer um compromisso consistente e efetivo com a democracia sem enfrentar os traumas de seu próprio passado. A aproximação, nesse aspecto, com a psicanálise freudiana é bastante evidente ${ }^{159}$. Sem

\footnotetext{
${ }^{156}$ O’DONNELL, Guillermo; SCHMITTER, Philippe C. Transições do regime autoritário, p. 57. Para melhor compreensão desse interessante argumento de O'Donnell, é pertinente lembrar que Maquiavel foi celebrizado, dentre outros méritos, exatamente por uma teoria que promoveu uma relativa dissociação entre a moral política e as demais morais. A partir dessa autonomização da moral política, esse autor conseguiu traçar uma série de prescrições aos governantes (homens públicos e não privados, como se costuma pensar), que vão de encontro ao que, intuitivamente e no senso comum, poder-se-ia considerar um bom governo. Para se ater a alguns exemplos dessa afirmação em sua obra clássica: "a crueldade, bem empregada - se é lícito falar bem do mal - é aquela que se faz de uma só vez, por necessidade de segurança" (p. 76); "um príncipe não deve preocupar-se com a má fama de cruel se quiser manter seus súditos unidos e fiéis" (p. 101); "quanto à questão de ser temido e amado, concluo que, se os homens amam de acordo com sua vontade e temem segundo a vontade do príncipe, um príncipe sábio deve assentar-se naquilo que é seu, e não no que é de outrem" (p. 104); e "portanto, um soberano prudente não deve manter a [sua] palavra" (p. 105). Todas as referências em MAQUIAVEL, Nicolau. O príncipe. São Paulo: Penguin Classics Companhia das Letras, 2010.

${ }_{157}^{157}$ O'DONNELL, Guillermo; SCHMITTER, Philippe C. Transições do regime autoritário, p. 57.

${ }_{158}$ O'DONNELL, Guillermo; SCHMITTER, Philippe C. Transições do regime autoritário, p. 57.

159 Para um aprofundamento da noção de compulsão à repetição do recalcado, que retorna como sintoma, aplicada a esse campo social, ver KEHL, Maria Rita. Tortura e sintoma social. In: TELES, Edson; SAFATLE, Vladimir (Org.). O que resta da Ditadura, p. 123-132.
} 
aprofundar esse aspecto, que demandaria uma reflexão à parte, aqui se encontra o germe de um princípio que será cada vez mais difundido nos debates em torno do legado do autoritarismo, como um verdadeiro lema: lembrar, para que não se repita.

A inspiração central é a ideia de que a elaboração e a representação de uma experiência traumática e desagradável permitem a convivência do sujeito com aquele passado de forma menos conflitiva e mais saudável. Do plano individual, essa ideia foi transplantada para o âmbito social ${ }^{160}$. Por isso, a afirmação de O’Donnell no sentido de que não haverá bases de sustentação social e ideológica à democracia política sem que sejam assumidos, de alguma forma, os elementos mais doloroso do seu passado:

\begin{abstract}
Recusando-se a enfrentar e a purgar-se dos seus piores temores e ressentimentos, uma sociedade que se vê diante desse problema estaria esquecendo não apenas o passado, mas os próprios valores éticos de que necessita para que o seu futuro mereça ser vivido. Portanto, diríamos que, a despeito dos enormes riscos que envolve, a estratégia "menos pior" em tais casos extremos é reforçar a coragem política e pessoal para impor julgamento àqueles acusados de grandes violações dos direitos humanos sob o regime anterior ${ }^{161}$.
\end{abstract}

Nesse caso particular, portanto, há uma relativização da orientação mais geral da forma adequada de tratar esse passado de violências durante as transições políticas. Essa constatação permite inferir que a avaliação desses autores é baseada em um marcante casuísmo. Tomam por base aqueles parâmetros mínimos, há pouco enunciados, quais sejam, a magnitude e a qualidade da repressão, bem como o decurso do tempo ocorrido após as violações de direitos humanos. Todos esses critérios, em resumo, estão atrelados a uma ideia de funcionalidade das medidas em relação ao processo de democratização, em

\footnotetext{
${ }^{160}$ Como tivemos a oportunidade de apontar em trabalho anterior, o objetivo maior de enfrentar um passado bloqueado e liberá-lo para acesso da memória é a elaboração dessas experiências, mediante a construção coletiva de uma verdade que essa tarefa exige. O grande lema, nesses casos, é recordar para não repetir, traduzido para o contexto latinoa-mericano, pioneiramente, pelo Nunca Más argentino, que foi também o nome da publicação oficial elaborada pela Comisión Nacional sobre la Desaparición de Personas (CONADEP), presidida pelo escritor Ernesto Sábato. Cf. QUINALHA, Renan Honório; SOARES, Inês Prado. A memória e seus abrigos: considerações sobre os lugares de memória e seus valores de referência. Anistia Política e Justiça de Transição, Brasília, Ministério da Justiça, n. 4, p. 250-278, jul./dez. 2010.

161 O’DONNELL, Guillermo; SCHMITTER, Philippe C. Transições do regime autoritário, p. 58. Especificamente sobre o caso argentino, também Prezworski reconhece a gravidade extrema da situação que justificaria um tratamento diferenciado: "Na maioria dos países latino-americanos, os militares preservaram a sua autonomia e continuaram a exercer tutela sobre o sistema político, ainda que não apenas em países onde a transição para a democracia foi resultado de negociações (...). A experiência argentina é particularmente comovente, já que a impunidade aproveitada por sequestradores, torturadores e assassinos têm um efeito profundamente desmoralizador sobre toda a vida política". No original: "In most Latin American countries, the military have preserved their autonomy and have continued to exercise tutelage over the political system, not only in countries where the transition to democracy was a result of negotiations (...). The Argentine experience is particularly poignant, since the impunity enjoyed by kidnappers, torturers, and murderers has a profoundly demoralizing effect on all political life". PRZEWORSKI, Adam. Democracy and Market, p. 75.
} 
uma perspectiva de evitar o conflito e permitir a acomodação dos interesses sob a égide das regras e instituições democráticas.

Evidentemente, esses parâmetros são insuficientes e precários para permitir um julgamento mais universal das distintas situações transicionais, não servindo de base para estruturar-se uma teoria mais consistente capaz de abranger esse dilema, que permanece como um dos pontos críticos dessa tradição.

Foi justamente a partir dessa lacuna que emergiu, inicialmente nas reflexões acadêmicas no campo da ciência política e, em seguida, no direito, o conceito de justiça de transição, catalisando alguns aspectos sinalizados nessa tradição que se dedicou ao estudo das transições. Mas, sobretudo, alterando e problematizando inúmeras outras questões negligenciadas nesses primeiros estudos.

Assim, o tratamento teórico deficitário e marginal conferido ao problema da justiça em momentos de transição, junto com o processo de afirmação progressiva dos direitos humanos na ordem internacional, estimulou o surgimento desse conceito, que já foi definitivamente incorporado ao vocabulário da política contemporânea.

\subsection{Justiça de transição: preenchendo uma lacuna}

Como visto, no pensamento desses autores que se debruçaram sobre as transições sul-europeias e latino-americanas, supunha-se que medidas de justiça, durante os tensos momentos de negociação, poderiam bloquear e até regredir um processo transicional. Em meio aos cálculos das elites políticas, os atores por excelência, a dimensão moral dos reclamos por justiça das vítimas era relativizada, posto que era negligenciada em favor da estabilidade e do balanço das forças políticas. A justiça, nas raras vezes em que aparecia nessas análises, surgia apenas como um questionamento de ordem utilitarista, sendo que a conclusão geralmente se encaminhava no sentido de que essas reivindicações poderiam prejudicar a normalidade da transição.

Se a primeira geração de estudiosos tinha como preocupação central a continuidade das democratizações, o que significa consagrar, em alta conta, o imperativo de evitar uma regressão autoritária, outro tem sido o enfoque dos estudos de justiça de transição. Nestes, passou-se a questionar sobre os traços da justiça nos lapsos de excepcionalidade política. 
Assim, considera-se que o estudo do direito, pensado normalmente para períodos de estabilidade política, não é menos relevante do que a perspectiva que privilegia a dimensão política da transição. Com efeito, o funcionamento ordinário e a estabilidade característica e até estruturante do direito em tempos de normalidade não persistem diante das profundas modificações políticas a que estão sujeitas as sociedades.

Essa distância e até mesmo contraposição entre processos de transição política e o direito, acolhidas nas primeiras reflexões já examinadas, afastaram tais questões do centro de preocupações das ciências jurídicas. No entanto, o papel do direito não é menor nesses processos: longe de ser apenas afetado passivamente, ele influencia e retroalimenta, com suas especificidades, os estímulos transicionais, marcados por constantes fases de inflexões e inovações nos procedimentos e instituições já tradicionalizados.

Neste cenário, emerge um conceito que tem despertado a atenção de cientistas sociais e, ainda em menor grau, de pesquisadores atuantes no campo do Direito. Isso porque, apesar da forte relação entre o nascimento da sociologia do direito e a resistência ao autoritarismo no Brasil e, a seguir, da tarefa de redemocratizar e reconstitucionalizar um Estado de Direito em nosso país, outras relações foram privilegiadas como objeto de investigação a partir dos anos $1990^{162}$.

Esse conceito presente nas fronteiras entre as ciências política e jurídica é o que se convencionou designar por justiça de transição ou justiça transicional. Refere-se, basicamente, aos desafios da recuperação de direitos e da instauração de regimes democráticos em momentos de excepcionalidade política. Por óbvio, essa tarefa não pode operar no vazio, mas somente a partir das condições legais e institucionais legadas do regime anterior. Se este foi marcado por uma sistemática e massiva prática de violação aos direitos humanos, como os regimes autoritários privilegiados nesse estudo, ampliam-se as dificuldades e dimensões em que a transição precisa ser trabalhada.

Com efeito, após contextos marcados por violência em escala e proporção muito grandes, é imperativo buscar referências éticas e parâmetros jurídicos novos para se restabelecer a vida em comunidade, estruturando regimes políticos democráticos e de soberania popular. Dentre as inúmeras dúvidas, há uma certeza nesta situação generalizada

\footnotetext{
${ }^{162}$ Para um inventário analítico das preocupações temáticas e dos principais trabalhos de pesquisa no campo da sociologia jurídica brasileira, ver FARIA, José Eduardo; CAMPILONGO, Celso. Sociologia jurídica no Brasil. Porto Alegre: Sergio Antonio Fabris, 1991.
} 
de desrespeito a direitos fundamentais: não se pode recomeçar de onde se tinha parado, como se nada tivesse acontecido.

Diversos são os exemplos históricos que ilustram a impossibilidade de retomar a convivência democrática do momento em que ela foi interrompida, sem que haja um olhar especialmente voltado aos elementos do passado que persistem no presente. Em outras palavras, o desafio de uma transição nunca se resume à mera restauração de uma ordem antiga temporariamente suspensa, como se se tratasse de recolocar nos trilhos a evolução de uma determinada comunidade. Daí que um dos equívocos mais comuns a serem evitados consiste, justamente, “em supor que o período autoritário representa, por assim dizer, um parêntese histórico e que a retomada do controle dos fios do destino se dará em circunstâncias mais ou menos similares às que prevaleciam no tempo pré-autoritário"163.

Nos casos dos regimes autoritários da América Latina e do Sul da Europa, a impossibilidade do mero retorno ao status quo ante foi potencializada tanto pelo caráter recente das violações massivas de direitos, como pela desfiguração do ideal de vida compartilhada que a extrema violência e a supressão das liberdades públicas causaram nessas sociedades.

Os regimes de exceção, caracterizados pela repressão e perseguição de opositores, justificadas geralmente por motivos de ordem político-ideológica, afrontaram diretamente o direito internacional dos direitos humanos, produto da progressiva afirmação de valores e princípios de proteção da pessoa humana na ordem internacional em um contexto de intensa globalização.

Essa conjuntura, aliada ao objetivo declarado das transições enunciadas na contemporaneidade, que foi o restabelecimento de regimes democrático-liberais sob império da legalidade, com a forma institucional do Estado Democrático de Direito de feição constitucional, estimulou a emergência desse novo conceito. No centro dos debates políticos na ordem internacional, começaram a marcar presença concepções de justiça e de direito capazes de contribuir decisivamente para coibir a perpetuação dos abusos perpetrados por parte dos agentes do Estado e, de algum modo, permitir a reparação e neutralização das fraturas e traumas herdados desse passado autoritário.

Passe-se, então, à análise do conceito.

${ }^{163}$ SANTOS, Wanderley Guilherme dos. O século de Michels, p. 112. 


\subsubsection{A demarcação do novo campo: um conceito de justiça de transição}

O termo "justiça de transição", tal qual utilizado neste trabalho, não expressa uma categoria analítica definitiva e acabada, mas, antes, uma referência tópica concebida pela teoria social contemporânea para delimitar os contornos de um tipo peculiar de experiência política e jurídica. Isso porque já se tornou lugar comum na literatura especializada que essa expressão designa um campo de reflexões e pesquisas ainda incipiente, que começa a ensaiar seus primeiros passos ${ }^{164}$. Não há dúvidas, contudo, que está em franca ascensão nos debates acadêmicos e institucionais ${ }^{165}$.

Basicamente, trata-se de uma justiça adaptada a sociedades que estão atravessando ou que recém-atravessaram situações extremas de violência ou conflito, cuja gravidade foi capaz de prejudicar a estabilidade política e a coesão social que fundavam a vida em comum ${ }^{166}$. Essa é a ideia forte do conceito.

${ }^{164} \mathrm{O}$ fato do conceito ser tão recente no âmbito das ciências humanas, não possuindo mais do que duas décadas, tem algumas consequências limitadoras para a incursão nessa temática. A primeira é que não há contornos claros que delimitem esse campo, pois "a justiça transicional é um campo relativamente novo, e suas fronteiras ainda não foram claramente definidas (...) operamos em um contexto em que (...) as regras de engajamento intelectual não estão claras". No original: "the field of transitional justice is a relatively new one, and its boundaries have not yet been clearly defined (...) we operate in a context where (...) the rules of intelectual engagement [are] unclear”. OKELLO, Moses Chrispus. Elevating transitional local justice or crystalizing global governance. In: SHAW, Rosalind; WALDORF, Lars; HAZAN, Pierre (Ed.). Localizing transicional justice: interventions and priorities after mass violence. Stanford: Stanford University, 2010. p. 283. Outro dado complicador indicado, tido como uma consequência menos imediata desse caráter recente, mas igualmente importante, é a de que há uma ausência de especialistas e interlocuções consolidadas, pois "a relativamente recente emergência da justiça de transição enquanto um campo separado de estudos significa que há uma falta de redes estabilizadas de especialistas". No original: "the relatively recente emergence of transitional justice as a separate field of study means there is a lack of established networks of expertise". BAXTER, Victoria. Critical challenges for the development of the transitional justice research field. In: .; MERWE, Hugo Van Der; CHAPMAN, Audrey R. (Ed.). Assessing the impact of transitional justice. Washington DC: United States Institute of Peace, 2009. p. 325-333. p. 325.

165 "A justiça de transição é um campo com trajetória em ascensão. Em um período relativamente curto, veio dominar o debate sobre a intersecção entre democratização, proteção aos direitos humanos e reconstrução estatal após conflitos". No original: "Transitional justice is a field on an upward trajectory. In a relatively short period, it has come to dominate debates on the intersection between democratisation, human rights protections and state-reconstruction after conflicts". MCEVOY, Kieran. Letting go of legalism: developing a 'thicker' version of transional justice. In:____ _ MCGREGOR, Lorna (Ed.). Transitional Justice from Below: Grassroots Actvism and the Struggle for Change. Oxford and Portland, Oregon: Hart, 2008. p. 15-45.

${ }^{166}$ Conforme definição do International Center for Transitional Justice (ICTJ), não se trata de um tipo peculiar de justiça, mas de uma justiça adaptada a um determinado contexto: "a justiça de transição não é uma forma especial de justiça, mas a justiça adaptada a sociedades em transformação após um período de profundos abusos contra os direitos humanos. Em alguns casos, essas transformações acontecem repentinamente; em outras, elas podem ocorrer ao longo de muitas décadas". No original: "Transitional justice is not a special form of justice but justice adapted to societies transforming themselves after a period of pervasive human rights abuse. In some cases, these transformations happen suddenly; in others, they may take place over many decades". Disponível em: <http://www.ictj.org/en/tj/>. Acesso em: 03 nov. 2010. 
Com efeito, passado um contexto de guerra civil ou de terrorismo de Estado, para se ater a duas das fontes mais comuns de violação sistemática aos direitos humanos na modernidade, que também são as mais consideradas nessa literatura, coloca-se, de modo mais ou menos premente, a necessidade de uma série de medidas voltadas para a retomada da convivência social em um patamar mínimo de respeito à legalidade, aos valores éticos e à ordem democrática.

Em outras palavras, menos do que uma definição de conteúdo inteiramente determinado, o termo refere-se a um processo de ordem histórica e, portanto, contingente, que busca aliar imperativos de justiça com condições extremamente adversas. Manifesta-se em uma série de respostas, via de regra institucionais, no sentido de reparar, o mais ampla e profundamente possível, um legado traumático pós-conflitivo ou pós-autoritário que afeta a integração e o desenvolvimento de determinada sociedade.

Esse complexo de estratégias jurídicas e sociais, ativado tanto pelos diferentes poderes do Estado quanto agenciado pelos sujeitos da sociedade civil, a despeito de variarem a depender do contexto analisado, orienta-se basicamente por dois objetivos essenciais: por um lado, promover os direitos humanos violados e, por outro, fortalecer as instituições e as práticas democráticas.

O primeiro objetivo, de caráter promocional e retrospectivo, visa à reparação econômica e simbólica tanto da sociedade, de um modo geral, quanto das vítimas e de seus familiares, em particular, por conta de atos de violação aos direitos humanos já consumados; o segundo objetivo, de teor mais prospectivo e voltado ao futuro ${ }^{167}$, busca impedir a repetição da violência passada de modo a concretizar a transição e a consolidação democráticas. Dito de outro modo, as tarefas principais dessa espécie de

\footnotetext{
${ }^{167}$ Ainda que tradicionalmente prevaleça o primeiro olhar, o segundo tem cada vez mais tomado força. "Na literatura, os escritores em geral entendem a justiça de transição como olhar para trás: compensar as vítimas pelas suas perdas; punir malfeitores e forçar indivíduos a devolverem propriedades que foram injustamente adquiridas; e revelando a verdade sobre os eventos passados (...). Justiça de transição também pode ser entendida como um olhar ao futuro: fornecendo um método para as pessoas recuperarem tradições e instituições perdidas; privando ex-funcionários de influência política e econômica que poderiam usar para frustrar a reforma; sinalizando um compromisso com os direitos de propriedade, o mercado e as instituições democráticas; e estabelecendo precedentes constitucionais que possam dissuadir os novos líderes de repetir os abusos do antigo regime". No original: "In the literature, writers generally understand transitional justice as backward looking: compensating victims for their losses; punishing wrongdoers and forcing individuals to disgorge property that was wrongfully acquired; and revealing the truth about past events (...). Transitional justice can also be understood in forward looking terms: providing a method for the public to recapture lost traditions and institutions; depriving former officials of political and economic influence that they could use to frustrate reform; signaling a commitment to property rights, the market, and democratic institutions; and establishing constitutional precedents that may deter future leaders from repeating the abuses of the old regime". POSNER, Eric; VERMEULE, Adrian. Transitional justice as ordinary justice. Public Law and Legal Theory Paper Working Paper, University of Chicago, mar. 2003, p. 5. Disponível em: $<$ http://www.law.uchicago.edu/files/files/40.eap-av.transitional.both_.pdf>. Acesso em: 20 dez. 2011.
} 
terapia política seriam a elaboração de um trauma socialmente vivido, inicialmente pelo seu reconhecimento público e oficial, bem como por sua reparação, a fim de reduzir as chances de que se repita no futuro.

\subsubsection{O reenquadramento da justiça em uma era pós-westfaliana}

Episódios de violência extrema, na história da humanidade, não são fenômenos inéditos, tampouco se trata de invenções originais, concebidas ou postas em prática apenas na modernidade. Sequer é preciso fazer um inventário das guerras, autocracias, perseguições e atrocidades que acompanharam os últimos dois mil anos da vida humana em comunidade. No entanto, a maior integração da sociedade mundial e o avanço expressivo dos recursos de poder e tecnologia disponíveis conferiram escala e dimensão diferenciadas para os conflitos mais recentes.

Desse modo, apesar da justiça de transição remeter a acontecimentos que, pontual e dispersamente, podem ser verificados desde as origens das sociedades ocidentais, como na antiguidade clássica ${ }^{168}$, a abordagem mais sistemática desses fenômenos é muito mais contemporânea. Somente em condições muito especiais é que se tornou viável a afirmação de um conceito específico, construído a partir de uma perspectiva eminentemente teleológica, capaz de agregar distintos acontecimentos históricos e abrangendo desde demandas sociais até políticas públicas com estatuto próprio.

Nessa linha, vale notar que o termo "justice in times of transition", que deu origem à expressão justiça de transição, foi lançado somente em uma conferência proferida em 1992 pela teórica argentina Ruti Teitel ${ }^{169}$. Atenta às relações entre direito e justiça em momentos de excepcionalidade política, notadamente em transições entre regimes, essa autora priorizou, em sua análise, exemplos do passado recente, especialmente o período

\footnotetext{
${ }^{168}$ Nesse sentido, além das experiências modernas ocorridas no séc. XX, Elster dedica-se, detidamente, a dois outros capítulos da justiça de transição na história humana. Ele considera haver medidas de justiça transicional já na Grécia antiga (411 - 403 a.C.), bem como durante a Restauração Francesa pós-Napoleônica (1814 e 1815). Cf. ELSTER, Jon. Closing the books: transitional justice in historical perspective. New York: Cambridge University, 2004. p. 3-46.

169 A coletânea em três volumes organizada por Neil Kritz, em 1995, também foi fundamental para difundir esse termo e lançar as bases desse campo, por ter compilado diversos textos fundantes dessa disciplina então em formação. Cf. KRITZ, Neil. Transitional Justice: How Emerging Democracies Reckon with Former Regimes. v. I, II e III. Washington DC: United States Institute of Peace, 1995.
} 
que sucedeu a Segunda Grande Guerra, as democratizações latino-americanas nas décadas de 70 e 80 e a onda de liberalizações na Europa do Leste a partir de $1989^{170}$.

Esse caráter tipicamente moderno fica claro na genealogia que Teitel traça do conceito, ao estabelecer três fases históricas distintas desse desenvolvimento. A primeira delas - fase do pós-Segunda Grande Guerra - foi marcada pelo Tribunal de Nuremberg e definiu as dimensões fundamentais da justiça de transição, selando o triunfo do direito internacional, mas também o caráter ainda excepcional e raro desse tipo de experiência no mundo, debaixo de um contexto marcado pela Guerra Fria.

Por sua vez, a segunda fase refere-se ao que se convencionou chamar de "terceira onda" de transições, o que, como foi visto no capítulo 1, compreende desde as redemocratizações sul-europeias e latino-americanas, a partir de 1970, até a liberalização dos regimes autoritários do Leste Europeu, África e América Central, tendo um ponto algo no pós-1989. Essa fase seria marcada por uma concepção mais associada à construção nacional ("nation-building”), caracterizada por uma concepção de justiça mais local e privada.

Por fim, a terceira e atual fase emerge no fim do séc. XX, associada à globalização e marcada por uma normalização ("normalization") do paradigma da justiça de transição, que deixa de ser exceção e passa a ser a regra geral, amplamente adotada no plano internacional e definitivamente integrante do rol de políticas consagradas pelos organismos multilaterais ${ }^{171}$.

Nesse sentido, não há dúvidas de que a justiça de transição é produto de um período histórico bastante específico ${ }^{172}$. Não é razoável supor que experiências ancestrais inteiramente contingentes possam ser interpretadas à luz deste conceito tão recente. Isso porque o marco central do novo tratamento que esses fenômenos começaram a receber no

\footnotetext{
170 TEITEL, Ruti. Transitional Justice Genealogy. Harvard Human Rights Journal, v. 16, 2003. Disponível em: <http://www.law.harvard.edu/students/orgs/hrj/iss16/teitel.pdf>. Acesso em: 20 dez. 2011. p. 69-94. Abordando ainda esse último período, em sua obra já clássica, associa essa normalização à função ritual do direito em nossos tempos, em substituição àquela da religião no passado: "in the contemporary moment, the social rituals of passage appear not to derive from religion but from the law". TEITEL, Ruti. Transitional Justice. Nova York: Oxford University, 2000. p. 229.

${ }^{171}$ Nessa linha, pode-se afirmar que "a justiça de transição emergiu de suas origens historicamente excepcionais para tornar-se algo normal, institucionalizado e integrado". No original: "transitional justice has emerged from its historically exceptionalist origins to become something which is normal, institutionalised and mainstreamed". MCEVOY, Kieran. Letting go of legalism: developing a 'thicker' version of transional justice, p. 16.

${ }^{172}$ Nas palavras de Hazan, "transitional justice is the product of a specific time in history". HAZAN, Pierre. Transitional justice after september 11: a new rapport with Evil. In: ; SHAW, Rosalind; WALDORF, Lars (Ed.). Localizing transicional justice: interventions and priorities after mass violence. Stanford: Stanford University, 2010. p. 50.
} 
mundo todo é a ideia de uma "justiça global" ou "justiça transnacional"173, que só se viabilizou a partir do desenvolvimento histórico do direito internacional dos direitos humanos.

Com a mundialização, que se acentua no final do séc. $\mathrm{XX}$, não apenas os mercados foram integrados. Os espaços normativos também sofreram um processo de intensa mudança e marcante interpenetração, compondo uma rede regulatória mais capilarizada, horizontalizada e pluralista na ordem global ${ }^{174}$. Nessa linha, desponta como um fator fundamental não somente os impactos que a globalização teve sobre os processos jurídicos e judiciais, mas também sua profunda influência sobre o modo de perceber-se e a maneira encarar-se a própria ideia de justiça.

Nas palavras de Nancy Fraser, em intrigante texto sobre o assunto, "a globalização está mudando o modo pelo qual discutimos a justiça”. Essa filósofa afirma que o ultrapassado "enquadramento Keynesiano-Westfaliano" ${ }^{175}$ de justiça, típico do imaginário político dos tempos áureos da social-democracia, tem dado lugar aos primeiros sinais de emergência de um "regime pós-Westfaliano de direitos humanos", nos quais as disputas por justiça não estão mais confinadas aos territórios nacionais.

\footnotetext{
${ }^{173}$ Rainer Forst faz um interessante apanhado da polêmica entre o que classifica, artificialmente, como "estatistas" ("statists") e globalistas ("globalists"). Em especial, privilegia os argumentos dessas duas perspectivas em relação à seguinte questão: "[em que medida] o mundo como um todo é um contexto de justiça, ou seja, um contexto caracterizado por reivindicações conflitivas que exigem julgamento à luz dos princípios de justiça". No original: ("the world as a whole is a context of justice, that is, a context characterized by conflicting claims that call for adjudication in light of principles of justice"). Em sua conclusão, esse autor levanta a defesa de se conciliar os melhores argumentos de cada lado da contenda, preservando os contextos de justiça doméstico e global. Cf. FORST, Rainer. A critical theory of transnational justice. In: POGGE, Thomas W. Global justice. Malden; Oxford: Blackwell, 2001. p. 169-187.

${ }^{174}$ Diversos estudos importantes no campo da sociologia jurídica se dedicaram às relações entre direito e globalização, especialmente ao impacto desta naquele. Especificamente no campo dos direitos humanos, ver FARIA, José Eduardo. Os direitos humanos e o dilema latino-americano às vésperas do século XXI. Novos Estudos CEBRAP, São Paulo, n. 38, p. 61-78, mar. 1994 e FARIA, José Eduardo. Direitos humanos e globalização econômica: notas para uma discusão. Estudos Avançados, São Paulo, v. 11, n. 30, ago. 1997. Disponível em: $\quad<$ http://www.scielo.br/scielo.php?script=sci_arttext\&pid=S0103-40141997000200004>. Acesso em: 20 dez. 2011. Para um mapeamento das questões mais atuais, ver FARIA, José Eduardo. A globalização econômica e sua arquitetura jurídica (dez tendências do direito contemporâneo). Disponível em: $<\mathrm{http}: / /$ moodle.stoa.usp.br/file.php/491/8.1._Faria_-_A_globalizacao_economica_e_sua_arquitetura juridica. pdf $>$. Acesso em: 15 jan. 2012.

${ }^{175}$ Segundo Fraser, a expressão "enquadramento Keynesiano-Westfaliano" tem o propósito de assinalar os fundamentos nacionais-territoriais das disputas em torno da justiça no auge do Estado de bem-estar democrático do pós-guerra, entre os anos 1945 e 1970. FRASER, Nancy. Reenquadrando a justiça em um mundo globalizado. Lua Nova: Revista de Cultura e Política, São Paulo, 77, p. 11-39, 2009. Disponível em: $<$ http://www.scielo.br/pdf/ln/n77/a01n77.pdf $\geq$. Acesso em: 20 dez. 2011.p. 12. Nesse período, "o argumento concentrava-se precisamente no que deveria ser entendido como uma justa ordenação das relações sociais no interior da sociedade. Envolvidos na disputa sobre 'o que' era a justiça, os debatedores aparentemente não sentiam nenhuma necessidade de discutir o 'quem'. Com o enquadramento Keynesiano-Westfaliano firmemente estabelecido, tomava-se como certo que o 'quem' correspondia aos cidadãos nacionais” (p. 13).
} 
Isso porque os cidadãos começam a enxergar e a sentir, cada vez mais intensamente, "graças à elevada preocupação com a globalização e às instabilidades geopolíticas pós-Guerra Fria”, que os diferentes “processos sociais que moldam suas vidas rotineiramente transbordam as fronteiras territoriais" $" 176$. Viver bem, assim, não depende mais apenas do atendimento das demandas de justiça material no interior das sociedades e dos Estados nacionais, conforme uma teoria da justiça social sugere, mas também das garantias de dignidade e participação na ordem internacional, o que demanda uma "teoria da justiça democrática pós-Westfaliana"177.

Para essa mudança paradigmática, desempenham papel fundamental as "coalizões transnacionais dos ativistas dos direitos humanos" ${ }^{178}$, que se tornam possíveis em virtude do marcante desenvolvimento de uma "sociedade civil global", grande esperança dos teóricos para solucionar os déficits democráticos desse nova ordem mundial ${ }^{179}$. Essa nova conjuntura começa a representar uma renovação das formas tradicionais de mobilização e de tratamento envolvendo as violações de direitos humanos no plano global.

Especial destaque, nesse processo, deve ser conferido à proliferação de instâncias jurisdicionais supranacionais, já caracterizada como o mais importante fenômeno político singular ocorrido desde o fim da era da Guerra Fria ${ }^{180}$. Esses tribunais e cortes, com poder decisório vinculante ou mesmo apenas consultivo, cada vez mais disseminados nesse novo contexto, apontam para uma diluição entre os âmbitos domésticos e internacional, implodindo o enquadramento Keynesiano-Westfaliano.

176 FRASER, Nancy. Reenquadrando a justiça em um mundo globalizado, p. 14.

177 FRASER, Nancy. Reenquadrando a justiça em um mundo globalizado, p. 17. Daí essa autora concluir que, em relação a essa mudança paradigmática, "o efeito é trazer à tona a característica estrutural da atual conjuntura: as lutas por justiça em um mundo globalizado não podem alcançar êxito se não caminharem juntamente com as lutas por democracia metapolítica” (p. 34). Nessa linha, analisando os impactos da globalização para uma teoria das relações internacionais pós-westfaliana, Brown retoma a provocação "westfailure", para indicar a falência desse sistema. BROWN, Chris. Sovereignty, rights and justice: international political theory today. Cambridge: Polity, 2006 [2002]. p. 232 e ss.

178 SIKKINK, Kathryn; WALLING, Carrie Booth. Argentina's contribution to global trends in transitional justice. In: ROHT-ARRIAZA, Naomi; MARIEZCURRENA, Javier (Ed.). Transitional justice in the twentyfirst century: beyond truth versus justice. New York: Cambridge University, 2008 [2006]. p. 302.

${ }^{179}$ Cf. COHEN, Jean. Sociedade Civil e Globalização: Repensando Categorias. DADOS - Revista de Ciências Sociais, Rio de Janeiro, v. 46, n. 3, p. 419-459, 2003. p. 419 a 459.

${ }^{180}$ Em seu exame panorâmico sobre o presente estágio de desenvolvimento das jurisdições internacionais, Romano afirma que, quando os internacionalistas do futuro forem olhar para trás, provavelmente vão se referir "à enorme expansão e transformação da jurisdução internacional como o mais importante desenvolvimento singular da era pós-Guerra Fria". No original: "the enormous expansion and transformation of the international judiciary as the single most important development of the post-Cold War age". ROMANO, Cesare P. R. The proliferation of international judicials bodies: the pieces of the puzzle. New York University Journal of International Law and Politics, v. 31, p. 709-751, 1999. p. 709. Para uma interessante análise concreta dos avanços e recuos na atuação de jurisdições supranacionais (regionais, internacionais e universais), Cf. ROTH-ARRIAZA, Naomi; BERNABEU; Almudena. Justicia transnacional como un proceso híbrido. In: ALMQVIST, Jéssica; ESPÓSITO, Carlos. Justicia transicional en Iberoamérica. Madrid: Centro de Estudios Políticos y Constitucionales, 2009. p. 293-311. 
Com efeito, a crescente judicialização da política mundial passa a conferir funções inimagináveis antes ao direito nas relações internacionais. Comprovação quantitativa disso é o fato de que, em 2006, já era quase quarenta o número de experiências de cortes e tribunais que extrapolaram os limites nacionais em todo o mundo ${ }^{181}$.

Ainda que essa legislação e essas estruturas internacionais se expandam de maneiras assimétricas, a depender dos interesses envolvidos nessas formas regulatórias globais, é incontroversa a constatação de que os atores políticos e sociais dispõem, hoje, de diversos procedimentos e estruturas para encaminhar suas demandas de defesa e promoção dos direitos humanos.

Assim, diversos deveres consagrados na ordem internacional passaram a operar como complementos e até como restrições aos poderes regulatórios dos Estados-Nação, traçando alguns parâmetros limitadores não só da atuação ordinária destes perante seus cidadãos nos momentos ditos de normalidade, mas também nos tempos de exceção e de transição políticas ${ }^{182}$.

Dentro dessa dinâmica mais geral, pode-se afirmar que a temática estruturada em torno do conceito de justiça de transição constitui um ponto de vista privilegiado para compreender essa série de profundas e complexas mudanças.

Primeiro, porque ela limita o poder estatal e mina os fundamentos da soberania nacional $^{183}$. Em segundo lugar, nesse campo, são marcantes as atuações dos atores

181 Conforme Sikkink e Walling, "tem havido um aumento na judicialização ou legalização da política mundial nas últimas décadas. Dependendo como contamos, há agora entre dezessete e quarenta cortes e tribunais internacionais". No original: "there has been an increase in judicialization or legalization of world politics in the last few decades. Depending on how we count, there are now between seventeen and forty international courts and tribunals". SIKKINK, Kathryn; WALLING, Carrie Booth. Argentina's contribution to global trends in transitional justice, p. 302.

${ }^{182}$ Exemplos das normas internacionais de direitos humanos relevantes para essa discussão são "Carta del Tribunal Militar Internacional en el Acuerdo para el enjuiciamiento y castigo de los mayores criminales de guerra del Eje europeo (Acuerdo de Londres, 1945), la Declaración Universal de Derechos Humanos (1948), la Convención sobre la Prevención y Supresión del Crimen de Genocidio (1948), la Convención Internacional sobre la Supresión de todas las formas de Discriminación Racial (1965), el Pacto Internacional sobre Derechos Civiles y Políticos (1966), la Convención Internacional sobre la Supresión y el Castigo del Crimen de Segregación racial (1974), el Protocólo Adicional a las Convenciones de Ginebra del 12 de agosto de 1949, relacionando con la Protección de Víctimas de Conflictos Armados No-Internacionales, también conocido como Protocolo II (1977), la Convención sobre la Eliminación de todas las Formas de discriminación contra las Mujeres (1979), la Convención contra la Tortura y otros castigos Inhumanos o Degradantes (1984), la Convención sobre los Derechos del Niño (1989); y otros instrumentos aprobados a nivel regional, tal como la Convención Europea sobre la Protección de derechos humanos y Libertades Fundamentales (1950) Convención Estadounidense sobre Derechos Humanos (1978), y la Carta Africana sobre derechos humanos y Derechos de los Pueblos (1986)". CUEVA, Eduardo González. Perspectivas teóricas sobre la justicia transicional, p. 1.

183 "Nesse contexto de globalização neoliberal, a justiça transicional desempenha um papel essencial na limitação do poder do Estado. Ela debilita as fundações da soberania nacional”. No original: "in this context of neoliberal globalization, transitional justice plays an essential role in limiting state power. It undermines the foundation of national sovereignty". HAZAN, Pierre. Transitional justice after september 11, p. 55. 
políticos dessa sociedade civil mundial, aproveitando as estruturas de oportunidades das novas estruturas e instâncias judiciais naquilo que foi chamado de "mobilização jurídica transnacional" ${ }^{\prime 184}$. Nessa linha, os mecanismos de justiça transicional também contribuem, de maneira bastante significativa, para quebrar com a organização westfaliana da ordem internacional, inaugurando ao menos a potencialidade de um "mundo ilimitado"185.

Desse modo, não é exagero afirmar que a justiça de transição constitui, hoje, um dos mais importantes laboratórios de experimentações nesse novo paradigma de justiça global, parecendo tratar-se de uma espécie desse gênero mais amplo e ainda em desenvolvimento. Prova dessa centralidade da área de justiça transicional são dois fenômenos distintos entre si, já paradigmáticos, que ficaram conhecidos como "efeito Pinochet" ("Pinochet effect") ${ }^{186} \mathrm{e}$ "cascata de justiça" ("the justice cascade") ${ }^{187}$. Ambos são exemplos algo pontuais, mas patentemente sintomáticos de uma tendência mais geral, pois marcam um giro na direção de novas normas e práticas para prover um accountability em relação às violações aos direitos humanos.

Mas não foram apenas as mudanças no campo do direito internacional que se destacaram. É pertinente lembrar que foi em uma realidade internacional marcada pela forte crença no triunfo dos liberalismos político e econômico que se generalizou a justiça de transição enquanto um paradigma. A queda do muro de Berlim, simbolizando o fim da Guerra Fria e antecipando o colapso do bloco soviético de Estados, proclamou o

\footnotetext{
${ }^{184}$ SANTOS, Cecília MacDowell. A justiça ao serviço da memória: mobilização jurídica transnacional, direitos humanos e memória da ditadura. In: ; TELES, Edson; TELES, Janaína de Almeida (Org.). Desarquivando a ditadura: memória e justiça no Brasil. v. II. São Paulo: HUCITEC, 2009. p. 472-497.

185 "O mundo westfaliano é caracterizado pelo fechamento - geográfico, com a existência de fronteiras, e temporal, com o estatuto de limitações, inclusive para os crimes mais abomináveis (...). A justiça transicional quebra com essa organização do mundo. Ele é, por definição, pós-westfaliana: a imprescritibilidade dos crimes contra a humanidade e o desenvolvimento da justiça criminal internacional e transnacional inauguram, ao menos na teoria, um mundo ilimitado". No original: "The Westphalian world is characterized by closure geographic, with the existence of borders, and temporal, with the statute of limitations, including for the most abominable crimes...Transitional justice breaks with this organization of the world. It is, by definition, postWestphlian: the imprescriptibility of crimes against humanity and the development of international and transnational criminal justice open - at least in theory - toward an unlimited world". HAZAN, Pierre. Transitional justice after september 11, p. 55 .

${ }^{186}$ Foi considerado um exemplo ímpar de jurisdição universal na efetivação dos direitos humanos a prisão por 503 dias de Pinochet após uma viagem para Londres, por conta de um pedido de extradição oriundo de um processo que tramitava na justiça espanhola. Esse caso é detidamente analisado, com suas implicações para o novo direito internacional, em ROTH-ARRIAZA, Naomi. The Pinochet effect: transnational justice in the age of human rights. Pennsylvania: University of Pennsylvania, 2005.

187 "Justice cascade" refere-se ao seguinte fenômeno: "nas últimas duas décadas do séc. XX, houve uma enorme mudança nas normas internacionais no sentido de usar processos judiciais estrangeiros ou internacionais para responsabilizar indivíduos por crimes contrários aos direitos humanos". No original: "in the last two decades of the 20th century, there was a major international norms shift towards using foreign or international judicial processes to hold individuals accountable for human rights crimes". LUTZ, Ellen; SIKKINK, Kathryn. Justice cascade: the evolution and impact of foreign human rights trials in Latin America. Chicago Journal of International Law, v. 2, p. 1-34, 2001. p. 1.
} 
nascimento de uma nova conjuntura, então caracterizada pela "revolução democrática no mundo todo". A partir daí, as mais diversas mudanças políticas passaram a ser enquadradas pelo prisma da justiça de transição, a despeito das marcantes diferenças existentes entre os países $^{188}$.

Importante registrar que, ao mesmo tempo em que repercutia garantias lastreadas no campo dos direitos humanos na ordem internacional, esse conceito também passou a traduzir os valores e ideologias predominantes nessa nova ordem, sob hegemonia do ideário liberal-democrático e quando os Estados Unidos da América estavam no auge de seu poder ${ }^{189}$. Tanto na prática cotidiana das relações internacionais, como nas academias e teorias, portanto, a justiça de transição nasceu, nos começo dos anos 1990, sintomatizando e dando expressão a esse novo cenário global, contribuindo para um novo relacionamento entre política e moral, especialmente entre os processos de transição e os direitos humanos $^{190}$.

Pontuados esses aspectos contextuais, é possível, então, passar a um exame propriamente do conceito de justiça de transição.

\footnotetext{
${ }^{188}$ Hazan descreve com precisão esse momento histórico. Considera que a administração Reagan impôs o paradigma da transição por si mesmo, mais ao celebrar a 'revolução democrática no mundo todo' do que desdobrando-o. O conceito de transição rapidamente entrou na interpretação da nova realidade internacional (...). O colapso dos regimes comunistas simbolizado pela queda do Muro de Berlim estabeleceu o paradigma da transição e marcou o triunfo do liberalismo político e econômico (...) o paradigma da transição tornou-se o prisma através do qual se entendem as mudanças políticas ocorridas em cerca de cem países, que tinham, na maior parte das vezes, pouco em comum entre si". No original: "The Reagan administration had made the paradigm of transition its own by celebrating 'the worldwide democratic revolution' than unfolding. The concept of transition rapidly entered into the interpretation of the new international reality (...). The collapse of communist regimes symbolized by the fall of the Berlin Wall established the paradigm of transition and marks the triumph of political and economic liberalism (...) the transition paradigm became the prism through which to understand the political changes ocurring in some one hundred countries, which had, most of the time, little in common". HAZAN, Pierre. Transitional justice after september 11, p. 50.

${ }^{189}$ Essa espécie de contradição que, em verdade, é mais um produto da natureza polissêmica e controversa desse conceito vai permitir, por exemplo, que ela seja apropriada muitas vezes, de modo indevido, para a imposição de certos padrões hegemônicos em detrimento da diversidade, mantendo e legitimando distribuições desiguais de poder e processos de dominação. Esse ponto será melhor tratado mais à frente.

${ }^{190}$ Ainda nas palavras de Hazan, "foi nesse contexto específico que o conceito de justiça transicional nasceu, no começo da década de 1990. Ele traçou uma nova relação da sociedade com o mal, ao mesmo tempo em que articulou uma nova relação entre a política e moral. Na prática, a justiça de transição logo se estabeleceu como uma nova disciplina, ensinada nas universidades, alimentando-se das experiências da transição democrática conduzida na América Latina, África do Sul e Europa Central e Oriental. Esses processos de transição também traduzem os valores da nova ordem mundial, quando os Estados Unidos estavam no auge de seu poder". No original: "It was in the specific context that the concept of transitional justice was born, at the begginig of the 1990s. It drew a new rapport of society with evil at the same time that it articulated a new rapport between politics and morality. In practice, transitional justice was soon established as a new discipline taught in universities, feeding on experiences of democratic transition conducted in Latin America, South Africa, and central and eastern Europe. These processes of transition also translate into the values of the new world order, when the United States was at the height of its power". HAZAN, Pierre. Transitional justice after september 11, p. 50.
} 


\subsubsection{A concepção tradicional da justiça de transição}

Em sua definição, Ruti Teitel lança as bases do conceito e sua formulação mais célebre, ao escrever que justiça de transição pode ser "definida como uma concepção de justiça associada a períodos de mudança política, caracterizada por respostas legais para confrontar os abusos dos regimes repressivos anteriores"191.

Ainda que essa expressão decorra da união de duas palavras que, isoladamente, carregam múltiplos significados, "justiça" e "transição", a expressão em seu conjunto não é difícil de ser entendida. A primeira palavra refere-se, genericamente, aos objetivos visados nesse tipo de experiência, remetendo a um ideal do que seja justo ${ }^{192}$; a segunda, por sua vez, diz respeito ao contexto histórico particularmente considerado, nomeadamente, a um recorte temporal de excepcionalidade política, como discutido no capítulo anterior.

Assim, é possível sustentar que a associação entre ambas palavras acaba, em alguma medida, delimitando um pouco a multiplicidade de sentidos possíveis que cada uma encerra. Conjugados entre si, os dois vocábulos indicam não exatamente que se trata de um tipo diferente de justiça, mas do fenômeno da justiça em um período histórico determinado, qual seja, durante uma mudança entre regimes. Com efeito, a expressão originalmente adotada era justiça em períodos de transição (“justice in times of transition”), que escancarava mais claramente essa ideia.

A mais singular característica da justiça de transição é o fato dessa ocorrer em um momento de profundas mudanças políticas. Essa é, aliás, sua razão de existir. São justamente a incerteza e a instabilidade excepcionais que demandam uma concepção de justiça mais adequada e menos normalizada.

No entanto, curioso notar que a literatura sobre esse tema não tem se dedicado a uma discussão mais aprofundada em torno do significado do termo transição, a despeito de ser constitutivo do conceito e outrora ter sido tão caro às reflexões sobre a democracia no campo da Ciência Política. Preferem, no geral, enfocar os diversos mecanismos ou dimensões que compõem a justiça.

\footnotetext{
191 No original: "transitional justice can be defined as the conception of justice associated with periods of political change, characterized by legal responses to confront the wrong-doings of repressive predecessor regimes". TEITEL, Ruti. Transitional Justice Genealogy, p. 69.

${ }^{192}$ Com razão, Elster aponta que "a mais difícil tarefa é decifrar o "papel' da justiça". No original: "the most difficult task is to spell out the 'role' of justice". ELSTER, Jon. Closing the books, p. 79. Apesar da importância da discussão em torno do conceito e das teorias da justiça, o presente trabalho, pelas limitações e pelo recorte adotado, apenas considera o debate em torno da justiça de transição, apenas um capítulo dessa reflexão mais ampla sobre justiça.
} 
Algumas poucas vezes, os estudos fazem menção às teorias sobre transição, mas apenas de passagem e sem as problematizar significativamente ${ }^{193}$; normalmente, apenas se limitam a pontuar, de forma mais ou menos genérica, que, por transições, devem-se entender as mudanças na vida política, em sentido bastante amplo. Ou seja, compreendemse todas as injunções a que o poder está sujeito em uma sociedade moderna e dinâmica, em especial as democratizações quanto à passagem de um estado de guerra civil ou de extremo conflito para outro de paz e estabilidade.

A despeito dessa deficiência, que tem consequências que serão ressaltadas mais adiante, foram-se afirmando certos conteúdos básicos e diretrizes gerais para definir, ainda que por uma média, as hipóteses mais gerais que obedecem a padrões indutivamente construídos, que serão mais detidamente examinados na sequência.

\subsubsection{Os eixos principais: verdade, memória, justiça, reparação e reformas institucionais}

Em sua obra mais conhecida, Teitel consagra uma orientação metodológica de construção do conceito que já se tornou central nas discussões sobre esse tema. Sua perspectiva assume um caráter contextual e contingente, privilegiando os momentos de profundas transformações da política e os condicionantes daí decorrentes. Daí seu método ser eminentemente indutivo, comparativo e histórico, percorrendo a narrativa de diversos casos concretos a fim de extrair conclusões mais gerais de ordem teórica.

Além disso, tem um acento institucional, por privilegiar as respostas dadas pelo direito estatal nessas transições, acentuando, no entanto, uma dimensão construtivista de sua concepção, tanto do direito sobre a transição, quanto reciprocamente desta sobre aquele. Há, portanto, nas condições excepcionais da transição, uma via de mão dupla que valoriza o papel ativo do direito, algo inexistente nas primeiras reflexões sobre as

\footnotetext{
${ }^{193}$ Exemplo é o próprio Hazan, que assevera categoricamente que a justiça de transição resulta de um paradigma de transição desenvolvido por alguns poucos cientistas políticos norte-americanos, com destaque para O'Donnell e Schmitter, durante meados da década de 1980". No original: "Transitional justice stems from a paradigm of transition developed by a few American political scientists (O'Donnell and Schmitter 1986) in the mid-1980's". HAZAN, Pierre. Transitional justice after september 11, p. 50. Radicalizando sua crítica, esse autor chega a afirmar que The concept of transition - the definition of which was always problematic - no longer appears to be an explanatory political category.
} 
transições, como foi visto no capítulo anterior ${ }^{194}$. Outro aspecto importante é que essa autora assume um componente normativo em sua abordagem, visível no modo como retrata as mudanças de uma situação de menor para outra de maior democracia ${ }^{195}$.

No entanto, Teitel alega não resumir o seu conceito de democracia à liberalização, ainda que a tônica dos processos históricos por ela analisados tenha sido essa. Inclusive, sugere ser necessário um "afastamento de definir transições puramente em termos de procedimentos democráticos, como os processos eleitorais, em direção a uma investigação mais ampla sobre outras práticas que significam a aceitação da democracia liberal"196. Por fim, nota-se que adota uma análise fenomenológica ${ }^{197}$, voltando-se às diversas formas da legalidade nos períodos de transição, bem como à complementaridade entre essas diferentes manifestações legais, que seriam, basicamente, "punição, investigação histórica, reparações, expurgos e elaboração de nova constituição". Esses elementos conformam um padrão ou paradigma designado por "estudo do direito transicional"198.

Esses traços foram canonizados nos estudos que se seguiram, assumindo inquestionável estatuto de entendimento predominante em meio a essa literatura. Com pequenas variações na combinação entre os elementos, os ingredientes apontados são sempre os mesmos: verdade, memória, justiça, reparação e reforma das instituições (Estado de direito ou rule of Law).

Essa formulação que estrutura uma constelação composta por quatro ou cinco eixos centrais foi consagrada como a perspectiva oficial dos organismos estatais e internacionais, bem como tornou-se a visão mais difundida nas pesquisas acadêmicas sobre o assunto. É pertinente transcrever diretamente algumas dessas opiniões reconhecidas dentro desse tema para atestar que o argumento procede. Nessa linha, um reconhecido

\footnotetext{
194 "A concepção de justiça nos períodos de mudança política é extraordinária e construtivista: é alternadamente constituída pela e constitutiva da transição". No original: "The conception of justice in periods of political change is extraordinary and constructivist: it is alternately constituted by, and constitutive of, the transition". TEITEL, Ruti. Transitional Justice, p. 6.

${ }^{195}$ Nessa linha, essa autora afirma que "no período contemporâneo, o uso do termo transição passou a significar mudança em direção à liberalização, o que é reconhecidamente verdade nas transições discutidas aqui". No original: "in the contemporary period, the use of the term transition has come to mean change in a liberalizing direction, which is true concededly of the transitions discussed here". TEITEL, Ruti. Transitional Justice, p. 5.

${ }^{196}$ No original: "a move away from defining transitions purely in terms of democratic procedures, such as electoral processes, toward a broader inquiry into other practices signifying acceptance of liberal democracy". TEITEL, Ruti. Transitional Justice, p. 5.

${ }^{197}$ Diz expressamente que o objeto de seu livro é a "fenomenologia das transições liberalizantes" ("phenomenology of liberalizing transitions"). TEITEL, Ruti. Transitional Justice, p. 5.

${ }^{198}$ No original, "punishment, historical inquiry, reparations, purges, and constitution making" e "transitional jurisprudence". TEITEL, Ruti. Transitional Justice, p. 6 e 7.
} 
defensor dessa concepção de justiça de transição a partir de um rol de obrigações que o

Estado deve cumprir para as vítimas e a sociedade de modo geral, assim afirma:

a primeira (...) é uma obrigação de fazer justiça, isto é, processar e punir os autores dos abusos quando estes tiverem sido de natureza criminosa. A segunda obrigação é a de garantir às vítimas o direito de saber a verdade (...). A terceira obrigação é a concessão de reparações às vítimas de maneira que sejam reconhecidos seu valor e sua dignidade como seres humanos. Compensação financeira em quantias apropriadas é certamente uma parte disso, mas a obrigação também deve ser concebida como incluindo gestos não monetários que expressem o reconhecimento do dano causado a eles e um pedido de desculpas em nome da sociedade. Finalmente, os Estados são obrigados a fazer com que aqueles que cometeram os crimes, servindo a qualquer título as forças armadas ou de segurança do Estado, não devem ser autorizados a participar dos órgãos responsáveis pela aplicação democrática da lei que foram reconstituídos, nem daqueles relacionados à segurança ${ }^{199}$.

Neil Kritz também sustenta visão bastante semelhante da justiça de transição, privilegiando a verdade, a justiça, o rule of law (Estado de direito) e uma paz durável. Esse autor afirma expressamente haver

quatro objetivos básicos de qualquer programa de justiça transicional. Em ordem crescente de dificuldade, (...) o primeiro é determinar a verdade ao estabelecer um registro dos abusos aos direitos humanos. A verdade fornece a validação das vítimas e visa à instrução das gerações futuras. $\mathrm{O}$ segundo objetivo é a justiça. $\mathrm{O}$ terceiro é uma significativa reforma democrática, com o entrincheiramento do Estado de direito (rule of law) dentro da sociedade e a construção de uma sociedade com instituições que assegurem que os tipos de abusos tratados não se repitam. O quarto objetivo é uma paz durável, com a garantia de que o retorno à violência é bastante improvável (...). Juntos, esses quatro objetivos são os padrões pelos quais todas as políticas de justiça transicional devem ser $\operatorname{avaliadas}^{200}$.

199 No original: "the first (...) is an obligation to do justice, that is, to prosecute and punish the perpetrators of abuses when those abuses can be determined to have been criminal in nature. The second obligation is to grant victims the right to know the truth (...). The third obligation is to grant reparations to victims in a manner that recognizes their worth and their dignity as human beings. Monetary compensation in appropriate amounts is certainly a part, but the obligation should also be conceived as including nonmonetary gestures that express recognition of the harm done to them and an apology in the name of society. Finally, states are obliged to see to it that those who have commited the crimes while serving in any capacity in the armed or security forces of the state should not be allowed to continue on the rolls of reconstituted, democratic lawenforcement or security-related bodies". MÉNDEZ, Juan E. In defense of transitional justice. In: MCADAMS, A. James. Transitional justice and the rule of law in new democracies. Notre Dame: University of Notre Dame, 2001. p. 12. Acrescenta esse autor que essas obrigações têm de ser vistas e buscadas como processo e não como resultado. Utiliza inclusive a distinção entre "obligations of means and not of results" (p. 12).

${ }^{200}$ No original: "there are four basic objectives of any transitional justice program. In ascending levels of dificulty (...) the first is to determine the truth by establishing a record of human rights abuses. Truth provides validation for victims and is aimed at the instruction of future generations. The second objective is justice. The third is meaningful democratic reform, entrenchment of the rule of law within society, and building a society with institutions that ensure that the kinds of abuses being dealt with will not recur. The fourth objetctive is a durable peace with assurance that a return to violence is fairly unlikely (...). Together, these four objectives are the standards by which all transitional justice policies should be evaluated". KRITZ, Neil. Policy implications of empirical research on transitional justice. In: MERWE, Hugo Van Der; BAXTER, Victoria; CHAPMAN, Audrey R. (Ed.). Assessing the impact of transitional justice. Washington DC: United States Institute of Peace, 2009. p. 13 e 14. 
Por sua vez, Jon Elster afirma que "a justiça de transição é composta de processos judiciais, expurgos e reparações, que têm lugar após uma transição de um regime político para outro" ${ }^{201}$. Nessa mesma linha, há a definição de outros teóricos segundo a qual a justiça de transição é "o conjunto de processos destinados a abordar violações passadas aos direitos humanos na sequência de períodos de turbulência política, repressão estatal ou conflito armado"202.

Segundo Louis Bickford, outro notório estudioso desse campo, "a justiça de transição baseia-se na legislação internacional para argumentar que países em transição devem encarar certas obrigações legais, que incluem a interrupção dos abusos de direitos humanos, a investigação de crimes do passado, a identificação dos responsáveis por tais violações, a imposição de sanções àqueles responsáveis, o pagamento de reparações às vítimas, a prevenção de abusos futuros, a promoção e preservação da paz e a busca pela reconciliação individual e nacional"203.

Essa compreensão do fenômeno em seus traços mais gerais, conjugando a diversidade das medidas concretas de justiça com a excepcionalidade do contexto transicional, no sentido de reparar o passado e prover uma responsividade dos sujeitos, consagrou-se como uma das concepções mais difundidas e influentes nos estudos de ciência política e direito. Tal leitura vem informando, vale frisar, não apenas debates acadêmicos, mas diferentes políticas públicas nacionais sobre memória e justiça, além de organismos internacionais de promoção de direitos humanos.

Exemplo disso é o Relatório do Secretário-Geral ao Conselho de Segurança da Organização das Nações Unidas (ONU), n. S/2004/616 de 23 de agosto de 2004, intitulado O Estado de Direito e a justiça de transição em sociedades em conflito ou pós-conflito. No documento, afirma-se:

a noção de justiça de transição discutida no presente relatório compreende o conjunto de processos e mecanismos associados às tentativas da sociedade em

\footnotetext{
201 No original: "transitional justice is made up of the processes of trials, purges, and reparations that take place after the transition from one political regime to another". ELSTER, Jon. Closing the books, p. 1. Esse autor aporta uma perspectiva pecualiar da teoria da escolha racional na interpretação da dinâmica da justiça de transição. Discute motivações e preferências dos diferentes atores, detendo-se às preferências emocionais, racionais e de interesse na justiça de transição. Cf. ELSTER, Jon. Preference formation in transitional justice. In: KATZNELSON, Ira; WEINGAST, Barry (Ed.). Preferences and situations: points of intersection between historical and rational choice institucionalism. New York: Russel Sage Foundation, 2005.

${ }^{202}$ No original: "the array of processes designed to address past human rights violations following periods of political turmoil, state repression, or armed conflict". OLSEN, Tricia; PAYNE, Leigh; REITER, Andrew. Transitional Justice in balance: comparing processes, weighing efficacy. Washington: United States Institute of Peace, 2010. p. 11.

${ }^{203}$ BICKFORD, Louis apud MEZAROBBA, Glenda. O que é justiça de transição? Uma análise do conceito a partir do caso brasileiro. In: SOARES, Inês Prado; KISHI, Sandra (Coord.). Memória e verdade, p. 38.
} 
chegar a um acordo quanto ao grande legado de abusos cometidos no passado, a fim de assegurar que os responsáveis prestem contas de seus atos, que seja feita a justiça e se conquiste a reconciliação. Tais mecanismos podem ser judiciais e extrajudiciais, com diferentes níveis de envolvimento internacional (ou nenhum), bem como abarcar o juízo de processos individuais, reparações, busca de verdade, reforma institucional, investigação de antecedentes, a destituição de um cargo ou a combinação de todos esses procedimentos ${ }^{204}$.

Nesse mesmo sentido, compartilhando desse arcabouço analítico, formulou-se uma concepção denominada "holística" de justiça transicional, que afirma a insuficiência e a ineficiência da adoção de mecanismos isolados. Essa visão é propagada por um importante organismo internacional dedicado ao tema, o International Center for Transitional Justice (ICTJ), que possui grande influência na América Latina ${ }^{205}$. Segundo essa definição, justiça de transição "é a resposta para violações sistemáticas ou generalizadas de direitos humanos. Ela busca o reconhecimento das vítimas e a promoção de possibilidades para a paz, a reconciliação e a democracia"206.

De acordo com esses contornos básicos, a partir de uma lógica indutiva e considerando determinadas medidas concretas inter-relacionadas em uma perspectiva normativa e holística, outras abordagens, inclusive mais críticas, foram surgindo. Com ênfases diferenciadas, a partir da confrontação com experiências concretas, tem-se aperfeiçoado uma definição do conceito mais elaborada e adequada para as diferentes situações.

204 ORGANIZAÇÃO DAS NAÇÕES UNIDAS. O Estado de Direito e a justiça de transição em sociedades em conflito ou pós-conflito. Anistia Política e Justiça de Transição, Brasília, Ministério da Justiça, n. 1, p. 320-351, jan./jun. 2009. p. 325. Esse entendimento é inteiramente corroborado pelo recente relatório também do Secretário-Geral da ONU para o Conselho de Segurança, S/2011/634 de 12 de outubro de 2011, chamado "The rule of law and transitional justice in conflict and post-conflict societies", no qual se afirma novamente que as "iniciativas de justiça de transição podem envolver tanto mecanismos judiciais quanto não-judiciais, inclusive processos individuais, reparações, busca da verdade, reforma institucional, expurgos e demissões". No original: "Transitional justice initiatives may encompass both judicial and non-judicial mechanisms, including individual prosecutions, reparations, truth-seeking, institutional reform, vetting and dismissals", mimeo, p. 6. Importante registrar que (i) estabelecer uma responsabilidade penal, (ii) dar publicidade ao processo de justiça, (iii) prover reparação às vítimas e (iv) dar garantias de não repetição são quatro princípios que já estavam no no relatório das Nações Unidas intitulado "Informe final revisado acerca de la cuestión de la impunidad de los autores de violaciones de los derechos humanos (civiles y politicos)", conhecido como o "Relatório Joinet" (1997). CUEVA, Eduardo González. Perspectivas teóricas sobre la justicia transicional, p. 3.

${ }^{205}$ É inegável a influência desse órgão nas discussões sobre justiça transicional iniciadas tardiamente no Brasil. Em realidade, vale destacar que esse termo foi recepcionado e apropriado de forma mais sistemática nos últimos três anos em nosso país. Isso ocorreu tanto por meio dos formuladores e executores de políticas públicas no governo federal, destacando-se a Comissão de Anistia sob a gestão Paulo Abrão (2008- ), quanto na reflexão acadêmica, com a formação de uma rede nacional de pesquisadores e professores ligados a essa temática, conhecido como Grupo de Estudos sobre Internacionalização do Direito e Justiça de Transição (IDEJUST), em funcionamento desde 2009 e sediado no Instituto de Relações Internacionais da USP.

${ }^{206}$ No original: "is a response to systematic or widespread violations of human rights. It seeks recognition for victims and to promote possibilities for peace, reconciliation and democracy". Disponível em: $<$ http://www.ictj.org/en/tj/>. Acesso em: 03 nov. 2010. 
Ainda que não se possa, de antemão, traçar um rol taxativo dos elementos constitutivos deste conceito de justiça transicional, que varia a depender da perspectiva adotada e da realidade analisada, há um sentido mínimo e um traço comum nessa diversidade de experiências. As visões tradicionais identificam um corpo de medidas e mecanismos cuja recorrência sugere tratarem-se de aspectos definidores de uma autêntica justiça de transição, decorrendo, daí, a dimensão normativa geralmente presente nesse conceito.

Essa literatura costuma agrupar os exemplos mais constantes e reincidentes de medidas em alguns eixos principais, que consagram direitos das vítimas aos quais correspondem deveres dos Estados, destacando-se, desde logo, que a sistematização apresentada tem sérias limitações, que serão oportunamente indicadas.

O primeiro desses eixos seria o do direito à reparação, em sentido amplo, dos danos sofridos. Essa tarefa concretiza-se, normalmente, mediante a oferta de reparações pecuniárias e simbólicas para os perseguidos políticos ou para as famílias dos mortos e desaparecidos. Pode, também, ser uma reparação coletiva, direcionada para grupos específicos, ou mesmo para a sociedade de forma geral.

Por sua vez, a segunda dimensão, comumente designada como direito à memória, constituído, essencialmente, por políticas públicas e outras iniciativas orientadas tanto para homenagear os que foram perseguidos quanto para esclarecer o funcionamento da repressão, dando ampla repercussão social a essas informações. Essa dimensão é fundamental para o processo de construção coletiva e oficial de uma memória capaz de revelar não somente as formas de exercício do poder autoritário, mas também enaltecer o papel da resistência de setores da sociedade civil. Outras medidas simbólicas são a retirada de nomes de violadores dos direitos humanos de ruas e lugares públicos, bem como a construção de memorial e monumentos em homenagem às vítimas da criminalidade de Estado.

O terceiro grupo de medidas conforma o que se tem designado por direito à verdade, o que demanda o acesso a informações sobre os fatos ocorridos por parte das vítimas, de suas famílias e de toda a sociedade ${ }^{207}$. Para a consecução desse objetivo básico, há diversos mecanismos que podem ser adotados pelos governos e instituições internacionais para documentar e revelar as violências praticadas.

\footnotetext{
${ }^{207}$ No original: "establishing the truth about past human rights violations and patterns of violence is a central dimensions of transitional justice process". CHAPMAN, Audrey R. Truth finding in the transitional justice process. In: .; MERWE, Hugo Van Der; BAXTER, Victoria (Ed.). Assessing the impact of transitional justice. Washington DC: United States Institute of Peace, 2009. p. 91-113. p. 91.
} 
Uma das demandas principais nesse campo é a abertura total e irrestrita dos arquivos e da divulgação dos dados oficiais produzidos durante determinado regime violador sistemático de direitos ${ }^{208}$. Além disso, merecem destaques as comissões de verdade, amplamente adotadas nas diversas experiências transicionais como meio de se construir a verdade. Algumas dessas comissões têm o fim expresso de também promover a reconciliação. Seus objetivos básicos seriam: estabelecer uma lembrança autorizada e historicamente acurada do passado; superar a negação oficial e comunitária das atrocidades, violências ou abusos e lograr o conhecimento público deles; identificar vítimas das violações de direitos humanos e abusos para promover políticas de reparação efetivas; conhecer as circunstâncias em que ocorreram; identificar os artífices das violências e envergonhar socialmente os perpetradores pelos atos praticados (se possível, colhendo elementos que permitam o processamento penal); criar uma memória coletiva ou uma história comum, para um novo futuro; restaurar a dignidade das vítimas, encerrar os abusos, legitimar e promover a estabilidade do novo regime, promover a reconciliação sobre as divisões do passado, educar a população sobre o ocorrido, recomendar caminhos para coibir a repetição dessas práticas ${ }^{209}$.

Soma-se aos anteriores um quarto eixo, conhecido como direito à justiça, consiste na investigação dos fatos e na responsabilização jurídica (civil, penal e/ou administrativa) dos agentes violadores dos direitos humanos. Em outras palavras, é composta por uma série de tarefas como investigar, processar, apurar responsabilidades, sobretudo dos agentes públicos, além de puni-los penalmente.

Vale destacar que uma das questões mais críticas nas transições diz respeito às demandas relativas à justiça criminal ou justiça retroativa por parte das vítimas, que consistem na persecução penal de membros do governo autoritário que, de algum modo, estiveram envolvidos com as violações de direitos humanos ${ }^{210}$.

\footnotetext{
${ }^{208}$ Importante ressaltar que os acontecimentos e as versões da história registrados nos acervos oficiais da época da repressão não constituem exatamente a verdade buscada para a vida democrática, mas o registro dos arbítrios do poder autoritário.

${ }^{209}$ CHAPMAN, Audrey R. Truth finding in the transitional justice process, p. 93-95. O estudo clássico sobre esse tema, compilando diversas experiências, é HAYNER, Priscilla B. Unspeakable truths: confronting state terror and atrocity. New York: Routledge, 2001.

${ }^{210}$ Quando se examina a bibliografia específica, é nítida a diferença entre o grau de polêmica quanto a esse requisito (direito à justiça) em relação aos demais (direitos à reparação, à memória e à verdade). Entre os que defendem esses mecanismos penais, destacam-se COMPARATO, Fábio Konder. A responsabilidade do Estado brasileiro na questão dos desaparecidos durante o regime militar. In TELES, Janaína (Org.). Mortos e desaparecidos políticos: reparação ou impunidade?. São Paulo: Humanitas FFLCH/USP, 2001. p. 63; DALLARI, Dalmo de Abreu. Crimes sem anistia. In: TELES, Janaína (Org.). Mortos e desaparecidos políticos: reparação ou impunidade?. São Paulo: Humanitas FFLCH/USP, 2001. p. 33; BICUDO, Hélio. Lei da anistia e crimes conexos. In: TELES, Janaína (Org.). Mortos e desaparecidos políticos: reparação ou
} 
Isso porque é fato que todos os regimes políticos sucedem-se marcados por um grau variado de consenso e de embate entre atores representativos do antigo e dos novos tempos, envolvendo diversos temas e demandas. Destaca-se, no entanto, no cerne dessas transições, sobretudo quando prevaleceu no regime anterior um contexto de grave violência, uma questão inevitável a ser definida: o tratamento jurídico conferido aos que, com diversos graus de envolvimento, sustentaram e figuraram como quadros políticos do regime superado ${ }^{211}$. Geralmente, estes buscam, quando possível, proteger-se mediante a edição de atos normativos, revestidos formalmente de uma legalidade autoritária ou então inserem uma cláusula no contrato de negociação das transições que lhes garanta a almejada impunidade.

Isso porque a decisão de levar os responsáveis a julgamento não se resume a uma mera questão jurídica, envolvendo apenas institutos, técnicas e prazos processuais. Menos ainda trata somente de conceitos jurídicos como punibilidade, prescrição, graça ou anistia. Em realidade, parece-nos ser o direito à justiça o mais delicado aspecto e, normalmente, o obstáculo mais difícil de transpor-se para que se atinja a plena realização de uma autêntica experiência de justiça transicional nos países da América Latina. Isso se explica, basicamente, pelo elevado grau de tensão política e social que encerra a decisão de perseguir penalmente anos e até décadas após a redemocratização os crimes cometidos em um contexto de repressão política e de hierarquia militar.

impunidade?. São Paulo: Humanitas FFLCH/USP, 2001. p. 87; ZAFFARONI, Eugenio Raúl. Crímenes de masa. Buenos Aires: Madres de Plaza de Mayo, 2010. p. 31-38; MÉNDEZ, Juan E. In defense of transitional justice, p. 4 e SANCINETTI, Marcelo; FERRANTE, Marcelo. El derecho penal en la protección de los derechos humanos: la protección de los derechos humanos mediante el derecho penal en las transiciones democráticas. Buenos Aires: Hammurabi, [s.d]. p. 460. Dentre os que se posicionam contrariamente: BATISTA, Nilo. Nota Introdutória. In: DIMOULIS, Dimitri; MARTINS, Antonio; SWENSSON JUNIOR, Lauro Joppert (Org.). Justiça de Transição no Brasil: Direito, responsabilização e verdade. São Paulo: Saraiva; Direito GV, 2010. p. 16; SWENSSON JUNIOR, Lauro Joppert. Punição para os crimes da ditadura militar: contornos do conflito. In: DIMOULIS, Dimitri; MARTINS, Antonio; SWENSSON JUNIOR, Lauro Joppert (Org.). Justiça de Transição no Brasil: Direito, responsabilização e verdade. São Paulo: Saraiva; Direito GV, 2010. p. 44; DIAS, José Carlos. Os desaparecidos. In: TELES, Janaína (Org.). Mortos e desaparecidos políticos: reparação ou impunidade?. São Paulo: Humanitas FFLCH/USP, 2001. p. 71 e DIMOULIS, Dimitri. Justiça de transição e função anistiante no Brasil. Hipostasiações indevidas e caminhos de responsabilização. In: ; MARTINS, Antonio; SWENSSON JUNIOR, Lauro Joppert (Org.). Justiça de Transição no Brasil: Direito, responsabilização e verdade. São Paulo: Saraiva; Direito GV, 2010. p. 111; SCANLON, T. M. Punishment and the rule of law. In: KOH, Harold; SLYE, Ronald (Ed.). Deliberative democracy and human rights. New Haven: Yale University, 1999. p. 257-2711. Algumas posições intermediárias, conciliando anistia com persecução seletiva, podem ser vistas em FREEMAN, Mark. Necessary Evils: Amnesties and the search for justice. Cambridge: Cambridge University, 2009. p. 181; MINOW, Martha. Between vengeance and forgiveness: facing history after genocide and mass violence. Boston: Beacon, 1998. p. 50; MIHAI, Mihaela. Julgamentos penais em períodos de transição e o desafio das emoções: histórias de dois países. Revista Crítica de Ciências Sociais, Coimbra, n. 88, p. 155-184, 2010. p. 156 e NINO, Carlos. Juicio al mal absoluto, p. 169-191.

211 Nesse sentido, Méndez destaca que "an early test of their residual powers is, precisely, the attempt to protect their own representatives against any settling of accounts for the past human rights violations". MÉNDEZ, Juan E. In defense of transitional justice, p. 9. 
Pode-se dizer que essa decisão envolve variáveis de diversas ordens a serem ponderadas. Do ponto de vista jurídico, esse juízo carrega a tensão entre o direito internacional dos direitos humanos, com os mais caros princípios que sustentam o jus cogens e o direito internacional convencional e a questão das garantias individuais, sobretudo no campo penal, que são do mais alto valor nos Estados constitucionais de extração liberal, tais como o da irretroatividade da lei penal, prescrição da punibilidade, validade de anistias etc.

Em termos políticos, expressa um balanço entre os poderes, opondo a energia do novo regime ao resíduo de poder dos antigos governantes. Além disso, consolida uma verdade publicamente chancelada, em que se converte a versão oficial da história dos acontecimentos, bem como uma caracterização política e moral do regime anterior, que passa a ser visto como injusto e reprovável, colaborando para a estruturação de uma memória coletiva eticamente referenciada.

Culturalmente, também reflete a polarização entre, por um lado, os propósitos de reconciliação e pacificação, que trazem implícita certa ideia de perdão e esquecimento, e, por outro, a pressão por reparações econômica e simbólica, cujo pressuposto é o reconhecimento de abusos que foram efetivamente cometidos, trazendo à tona, como elemento central, a impunidade dos agentes responsáveis pela repressão política.

Por essas razões, pode-se apontar o direito à justiça como o mais delicado ponto nas transições, aspecto este já percebido pelos autores analisados no capítulo anterior. Mas, além dos quatro eixos mencionados, há um outro, que permeia todos os anteriores e que compreende o fortalecimento das instituições democráticas, tendo por finalidade a garantia de não repetição. Além de reformas institucionais e na legislação, pode-se mencionar o afastamento dos criminosos do regime anterior de órgãos relacionados ao exercício da lei e de posições de autoridade, os chamados expurgos ou lustrações.

Pode-se, assim, de acordo com essa literatura predominante, sintetizar os pilares de uma experiência básica e padrão de justiça transicional por meio da metáfora de proverse um acerto de contas ${ }^{212}$ em sentido amplo ("settling accounts" ou "accountability”) com o passado. Nessa perspectiva, as responsabilizações assumem papel central, sejam elas

\footnotetext{
212 A expressão "acerto de contas" para referir-se à justiça de transição, a meu ver, soa bastante inadequada, pois por mais que se a interprete metaforicamente, carrega um inevitável viés econômico, que restringe a complexidade e a potencialidade desse tipo de experiência. O problema parece ser que, nas traduções correntes, o termo "accountability", mais amplo e de difícil definição objetiva, acabou sendo reduzido a "settling accounts", cujo sentido é muito mais claramente econômico.
} 
individual ou coletiva, pessoal ou institucional, civil ou penal ${ }^{213}$. Esse acerto orienta-se pela fórmula "memória, verdade e justiça", ainda que cada um desses componentes guarde seu peso e idiossincrasia a depender da situação analisada.

Ruti Teitel, em outro texto, ressalta a relação normativa e positiva existente entre a justiça em um novo regime e as perspectivas para a democracia. Ela argumenta a existência de uma "relação poética entre a consciência do passado repressivo de um país e seu futuro. Através dessa contabilização histórica, o que está sendo proposto é um senso de justiça poética" ${ }^{214}$. Essa justiça poética proposta pela autora é que teria o condão de converter as narrativas históricas de tragédias, reais ou ficcionais, em algo positivo e otimista para o futuro.

Outra abordagem comum e mais trivial da justiça transicional, derivada também dessas visões mais tradicionais, consubstancia-se em uma série de dilemas postos ao juízo e à deliberação da sociedade civil organizada e dos poderes públicos, a depender do enfoque. Isso porque os objetivos transicionais, normalmente, entram em confronto com outros objetivos políticos do novo governo, haja vista que as violações de direitos humanos são apenas uma das pautas tensionadoras da transição política ${ }^{215}$. Nesse tipo de formulação, comumente, são apresentados dilemas da seguinte forma: "esquecimento x memória", "impunidade x justiça", "perdão x responsabilização", "verdade x negacionismo", "reparação x indiferença", "pacificação x persistência do conflito", "reconciliação x divisão da sociedade" etc. ${ }^{216}$.

213 As reflexões em torno da responsabilização, de diversas perspectivas teóricas, têm sido uma das abordagens mais profícuas da justiça de transiçãotemas. Nesse sentido, ver PAYNE, Leigh; ABRÃO, Paulo; TORELLY, Marcelo (Org.). A anistia na era da responsabilização: o Brasil em perspectiva internacional e comparada. Brasília: Ministério da Justiça, Comissão de Anistia; Oxford: Oxford University, Latin American Centre, 2011.

${ }^{214}$ No original: "a poetic relation between the knowledge of the country's repressive past and its future. Through the historical accountings, what is being propounded is a sense of poetic justice". TEITEL, Ruti. From dictatorship to democracy: the role of transitional justice. In: KOH, Harold; SLYE, Ronald (Ed.). Deliberative democracy and human rights. New Haven: Yale University, 1999. p. 287.

${ }^{215}$ Para Lutz, "os objetivos da justiça transicional não são os únicos itens na agenda pós-transicional. Governos de transição também devem abordar uma série de assuntos não-transicionais". No original: "transitional justice goals are not the only items on the post-transition agenda. Transitional governments must also address a host of non-transitional matters". LUTZ, Ellen. Transitional justice: lessons learned and the road ahead. In: ROHT-ARRIAZA, Naomi; MARIEZCURRENA, Javier (Ed.). Transitional justice in the twenty-first century: beyond truth versus justice. New York: Cambridge University, 2008 [2006]. p. 329. Indo além, pode-se afirmar que, durante as transições, despontam diversas outras pautas e demandas políticas, como as reformas econômicas, que também devem ser equilibradas e que de um ponto de vista pragmático e estratégico, podem gerar maior retorno político aos atores, com um desgaste até mesmo menor do que afetar os interesses fundamentais dos membros do regime autoritário anterior.

${ }^{216}$ Exemplo dessa formulação sempre dilemática dos objetivos da justiça de transição é a afirmação de que "um julgamento na sequência à atrocidades em massa, então, deve marcar um esforço entre a vingança e o perdão". No original: "a trial in the aftermath of mass atrocity, then, should mark an effort between vengeance and forgiveness". MINOW, Martha. Between vengeance and forgiveness, p. 26. O dilema "paz 
Esse tipo dilemático de abordagem já tem sido bastante criticado. Primeiro, porque assume binariedades que reduzem a complexidade e limitam o alcance da justiça de transição ${ }^{217}$. Segundo, porque os casos empíricos que passaram a ser analisados com essas referenciais demonstraram a "falácia dessas dicotomias" 218 . Terceiro, porque essas disjuntivas não se apresentam todas com o mesmo grau de urgência e importância nem, por consequência, são solucionadas todas simultaneamente em conjunto. Em outras palavras, dependendo do legado a que se busca superar, há decisões postas com maior nível de urgência.

Ademais, considerando que não se encontram soluções puras e unilaterais a esses dilemas enunciados típico-idealmente, esse modo de metaforização e de enquadramento da estrutura da justiça transicional, sob a forma de difíceis paradoxos (políticos, éticos, jurídicos etc.), tem sua validade comprometida como instrumento de análise, ainda que sirvam bem para ilustrar as contradições centrais desses processos.

Desse modo, tem prevalecido, nessa literatura, uma visão de justiça de transição que postula um modelo híbrido, de inspiração holística, em que cada um dos elementos mencionados são combinados de acordo com determinada realidade e contexto ${ }^{219}$. A

versus justiça" está presente na seleção de textos feita em STEINER, Henry; ALSTON, Philip; GOODMAN, Ryan. International human rights in context: law, politics, morals. Oxford: Oxford University, 2008. p. 1331 e ss.

${ }^{217}$ Por exemplo, uma discussão recorrente é se a justiça e a verdade podem ser vistas como obrigações alternativas: na impossibilidade de justiça, pelo menos que se garanta o direito à verdade. Essa visão tornouse bastante corrente e orientou algumas políticas de Estado importantes nesse tema. Inclusive parte das discussões em torno dessa questão no Brasil parece seguir esse rumo. Por isso, "uma crítica implícita (e às vezes explícita) das comissões de verdade é que na medida em que elas representam um desvio-algumas vezes apenas um complemento para, outras apenas uma substituição de-em relação aos procedimentos formais regularizados de direito penal, ou até mesmo aos litígios civis, elas são deficientes. São uma maneira distinta e a segunda melhor existente de averiguar a verdade sobre o passado e retificar, através da justiça corretiva, as injustiças que ocorreram". No original: “An implicit (and sometimes explicit) critique of truth comissions is that to the extent that they represent a deviation from-sometimes only a complement to, other times a substitution for-the regularized formal procedures of criminal law, or even civil litigation, they are deficient, a distinctly second-best way either of ascertaining the truth about the past or of rectifying, through corrective justice, the injustices that occurred than". LEVINSON, Sanford. Trials, comissions, and investigating comittees: the elusive search for norms of due process. In: ROTBERG, Robert; THOMPSON, Dennis (Ed.). Truth v. Justice: the morality of truth comissions. Princeton: Princeton University, 2000. p. 211. 218 " $\mathrm{Na}$ época anterior, acadêmicos e ativistas debateram o que era mais importante: verdade ou justiça? Justiça ou paz? Esses casos [analisados] demonstram a falácia dessas dicotomias". No original: "in earlier era, scholars and activists debated which was more important: truth or justice? Justice or Peace? These cases show the fallacy of such dichotomies". LUTZ, Ellen. Transitional justice: lessons learned and the road ahead, p. 327.

${ }^{219}$ Nesse sentido é a colocação de David Gray, ao referir-se à visão predominante: "essas considerações geralmente levam as transições a perseguirem programas 'híbridos' de justiça, compostos de processamento seletivo dos maiores líderes, anistias oficiais ou de fato, comissões de verdade, expurgos e reparações". No original: "These considerations usually lead transitions to pursue "hybrid" programs of justice composed of limited prosecutions focused on top leaders, official or de facto amnesties, truth commissions, lustration, and reparations". GRAY, David. An excused-centered approach to transitional justice. Fordham Law Review, n. 74, 2006, p. 2621-2694. Disponível em: <http://digitalcommons.law.umaryland.edu/fac_pubs/632/ >. Acesso em: 20 dez. 2011 . p. 2622. 
diferença, nessas combinações particulares, é o peso que cada autor dá às questões políticas, morais e legais, que compõem a chamada "tríade temática" da justiça transicional $^{220}$.

\subsubsection{Classificação das abordagens tradicionais: entre a moral, o direito e a política}

Como foi visto, toda transição apresenta, em seu curso, uma enorme gama de problemas a serem enfrentados, de diversas ordens. Isso permite que diferentes análises enfoquem aspectos distintos entre si. Nessa linha, a depender da experiência analisada e das inclinações subjetivas do observador, haverá uma hierarquização peculiar entre as questões políticas, as morais e as legais.

Nessa direção, sistematizando os principais delineamentos do desenvolvimento dessas reflexões, Tricia Olsen, Leigh Payne e Andrew Reiter classificaram as abordagens tradicionais sobre justiça de transição de acordo com o tipo ou com os tipos de medidas privilegiadas. Esses autores traçaram quatro categorias: minimalista, maximalista, moderada e holística, que são descritas a seguir:

\footnotetext{
Uma abordagem maximalista favorece um imperativo moral, legal e político para processar as violações aos direitos humanos. Em contraste, uma abordagem minimalista ou consequencialista enfatiza o perigo de julgamentos e defende a concessão de anistias para assegurar a paz e a transição democrática. Uma terceira abordagem mais moderada enfatiza o valor das comissões de verdade sobre outros mecanismos por visar à demanda por algum tipo de prestação de contas ao mesmo tempo reconhecendo as restrições políticas que impedem julgamentos. Estas três abordagens fornecem um conjunto de proposições teóricas para quando e por que certos mecanismos de justiça transicional atingem seus objetivos. Uma quarta abordagem holística enfatiza a importância de combinar esses mecanismos. Ela argumenta que os mecanismos isolados não atingirão as metas da justiça transicional e defendem, ao invés, o uso de múltiplos mecanismos ${ }^{221}$.
}

220 CUEVA, Eduardo González. Perspectivas teóricas sobre la justicia transicional, p. 3. A despeito de bem explorada por esse autor, é preciso registrar que essa compreensão dos problemas de justiça nas transições a partir dessa tríade formada pela moral, pelo direito e pela política remonta a reflexões anteriores. Carlos Santiago Nino estrutura parte de seu livro a partir dos "problemas políticos, dos dilemas morais e dos problemas legais" do julgamento das violações de direitos humanos. NINO, Carlos. Juicio al mal absoluto. Também Juan Méndez afirma que "corrigir os erros cometidos através das violações aos direitos humanos não é apenas uma obrigação legal ou um imperativo moral imposto aos governantes. Também faz sentido politicamente na transição da ditadura para a democracia. No original: "Redressing the wrongs committed through human rights violations is not only a legal obligation and a moral imperative imposed on governments. It also makes good political sense in the transition from dictatorship to democracy”. MÉNDEZ, Juan E. In defense of transitional justice, p. 1.

${ }^{221}$ No original: “A maximalist approach advances a moral, legal, and political imperative for prosecuting past human rights violations. In contrast, a minimalist, or consequentialist, approach emphasizes the danger of trials and advocates amnesties to ensure peace and democratic transition. A third, moderate approach 
Nota-se que essa classificação está organizada a partir de uma escala, que vai da minimalista, que privilegia a dimensão política das necessidades de estabilização antes de qualquer outro objetivo, até a maximalista, que acolhe as dimensões morais e legais de julgar os responsáveis pelas violações de direitos humanos. A moderada, como o próprio nome sugere, é uma categoria intermediária nessa escala. Por fim, a abordagem holística adota uma perspectiva mais flexível e híbrida de combinação desses diferentes mecanismos.

Eduardo Cueva desenvolve uma outra forma bastante interessante e mais sofisticada de sistematizar essas visões possíveis sobre a justiça transicional. Aponta seis formas diferentes de compreensão desse mesmo conceito, a depender do peso conferido aos fatores políticos, morais e legais, bem como das múltiplas possibilidades de combinálos.

A primeira visão é a que compreende a justiça transicional como um instrumento político à disposição de atores que se movem em um ambiente político bastante fluído. Nesse sentido, trata-se de uma arena estratégica para transações políticas que alteram a correlação de forças resultantes da transição em um contexto geral de enfraquecimento das forças egressas do autoritarismo. A segunda perspectiva possível é a que caracteriza a justiça transicional como uma resposta do direito ao autoritarismo, ou seja, como uma resposta político-governamental a um complexo de expectativas surgidas na queda de um regime autoritário e durante a emergência de um novo regime.

Por sua vez, a terceira abordagem entende esse conceito com um dilema técnicojurídico, que consiste em saber como preservar os princípios do devido processo legal e a independência do Poder Judiciário no enfrentamento de casos numerosos, sobre os quais costuma existir poucos materiais probatórios ou para os quais pode haver um marco legal insuficiente. Um quarto tipo de análise indica a justiça de transição como um assunto de promessa moral ou cultura política. A ideia central, aqui, é que a punição daqueles que infringiram normas básicas de coexistência social e o reestabelecimento da dignidade das vítimas permitem caminhar para uma restauração moral e para a erosão das hegemonias culturais que tornaram possível a violência.

emphasizes the value of truth commissions over other mechanisms by addressing the demand for some form of accountability while simultaneously acknowledging political constraints that impede trials. These three approaches provide a set of theoretical propositions for when and why certain transitional justice mechanisms achieve their goals. A fourth, holistic approach emphasizes the importance of combining these mechanisms. It argues that single mechanisms will not achieve transitional justice goals, and advocates multiple mechanisms instead". OLSEN, Tricia; PAYNE, Leigh; REITER, Andrew. Transitional Justice in balance, p. 16. 
Outro olhar possível sobre esse mesmo fenômeno, o quinto da lista, é o que prestigia uma dimensão político-cultural, particularmente a necessidade transcendental de redefinir a verdade histórica e resgatar a memória das vítimas, às quais se concede a oportunidade de afirmar sua própria dignidade mediante narrativas alternativas que subvertam a história oficial imposta pelo regime anterior. Por fim, a sexta perspectiva considera a justiça transicional como um problema de reconciliação social, privilegiando os efeitos psicológicos decorrentes dos ultrajes cometidos durante a ditadura tanto nos perpetradores quanto nas vítimas ${ }^{222}$.

Todos esses diferentes olhares, contudo, não são excludentes entre si. Pelo contrário, esse autor sustenta que não há forma pura, pois no mundo da política real, há discursos e práticas ecléticas, até mesmo contraditórias. Por isso, há, em seu escrito, uma veemente defesa da justiça de transição enquanto uma questão complexa que envolve todas essas dimensões, refutando a ideia dessa experiência enquanto um único problema, pois isso significaria reduzir a riqueza desses temas a uma única dimensão privilegiada, que normalmente é a conservação dos pactos políticos transicionais e a limitação posta pela correlação de forças. Essa visão reducionista, vale frisar, é exatamente aquela acolhida pela tradição de cientistas políticos que foram discutidos no capítulo primeiro.

Assumir essa diversidade e essa multiplicidade de dimensões implica lidar com um verdadeiro labirinto. De forma resumida, esse labirinto é composto centralmente por três categorias de problemas que esse autor assim resume: estratégico-políticas, éticoculturais e técnico-legais.

As considerações estratégico-políticas referem-se a interações estratégicas de atores com interesses dissonantes, com especial destaque para os líderes políticos que buscam fundamentalmente a consolidação do regime democrático. Nessa dimensão, prevalece um realismo que tende a dissociar as decisões políticas dos imperativos éticos e deveres legais.

Já o grupo de problemas ético-culturais emerge da existência das reivindicações de justiça por uma parte da população que adquirem eco na sociedade. Nesse nível, aos atores é bastante difícil aceitar as concessões e restrições que caracterizam o reino da política. Eles requerem a satisfação completa das suas demandas, com marcante urgência existencial.

${ }^{222}$ CUEVA, Eduardo González. Perspectivas teóricas sobre la justicia transicional, p. 4 e 5. 
Por fim, a terceira dimensão é de ordem técnico-legal. Nesse ponto, entram em cena os diversos mecanismos jurídicos utilizados para enfrentar as condutas criminosas e adjudicar as responsabilidades individuais, com o objetivo ideal de que o direito consiga mediar "as prioridades amorais da política com as exigências apolíticas da moral",223.

Esclarecida essa perspectiva tradicional e os desenvolvimentos que lhe foram incorporados em análises posteriores, é interessante passar a um exame das principais críticas que têm sido dirigidas a essas reflexões e aos métodos de investigação comumente empregados.

\subsubsection{Críticas às abordagens tradicionais da justiça de transição}

Diversas críticas instigantes têm sido elaboradas no sentido de problematizar não somente as imprecisões que os termos "justiça" e "transição" - isoladamente e mesmo conjugados - apresentam para tratar de contextos de excepcionalidade e de aceleradas transformações políticas. Apontam, também, as limitações teóricas e analíticas mais profundas dessa abordagem tradicional.

Dentre essas limitações, a primeira seria assumir, acriticamente e sem comprovação, o pressuposto de que o direito é mais influenciado pela política em momentos transicionais do que nos momentos de estabilidade. Os autores dessa crítica sustentam que, na realidade, essa influência seria uma regra da convivência entre direito e política em quaisquer contextos. Além disso, o privilégio do legalismo e da centralidade do Estado na agenda global da justiça de transição também é colocado em xeque. Critica-se, ainda, o fato de que tal concepção tradicional suporia certa progressividade e coerência na atuação do Estado nessa questão.

Soma-se a isso a dificuldade em se precisar os marcos inicial e final de um processo transicional, que delimitariam o momento peculiar da justiça analisada. Outro problema apontado são os conceitos de democratização e transição adotados, via de regra, lineares e, por isso, incapazes de compreender os laços de continuidade histórica. Nessa

${ }^{223}$ Esse modelo é proposto e bem desenvolvido por CUEVA, Eduardo González. Perspectivas teóricas sobre la justicia transicional, p. 9 e 10. 
perspectiva, essas visões reproduziriam a idealização das rupturas, distorção comum no calor das transições políticas ${ }^{224}$.

McEvoy chama atenção para a marcante predominância do legalismo (“dominance of legalism") existente nas análises tradicionais, afirmando que a "justiça de transição tornou-se dominada por uma lente estreita e legalista" ("transitional justice has become over dominated by a narrow, legalistic lens") ${ }^{225}$. Esse legalismo se expressa em três aspectos principais: no "legalismo como sedução" ("legalismo as seduction"), que se intensifica nos momentos instáveis das transições; no "legalismo como o triunfo dos direitos humanos" ("legalismo as the triumph of human rights"), discurso hegemônico global que unifica todos os tipos de perspectivas; e, por fim, no "legalismo como uma tendência ao estatalismo", que leva os envolvidos nos processos de justiça de transição a verem como Estado (“seeing like a state") 226 .

Outra crítica interessante é aquela que considera que os mecanismos de justiça transicional são seletivos e excludentes demais, por apenas considerar violações a direitos humanos apenas as agressões a garantias civis e políticas. Sob essa ótica, há um minimalismo conservador que silencia e até oculta outros tipos de sofrimentos sociais e econômicos impostos por regimes autoritários ou situações de guerra.

Nesse sentido, mencione-se a consideração de Hugo Merwe, que argumenta que “os mecanismos oficiais de transição geralmente são estreitos em seu escopo, enfocando formas particulares de abuso, prazos designados e categorias específicas de autores. O campo também é geralmente definido como criminal, quer em termos de direito internacional ou de acordo com a lei do Estado afetado (...). Esse foco efetivamente marginaliza abusos econômicos ou sociais que são mais comuns",227.

\footnotetext{
${ }^{224}$ Essas críticas são melhor exploradas em SANTOS, Cecília Macdowell. Memória na justiça: a mobilização dos direitos humanos e a construção da memória da ditadura no Brasil. Revista Crítica de Ciências Sociais, Coimbra, n. 88, p. 127-154, 2010. p. 133 e 134.

${ }^{225}$ MCEVOY, Kieran. Letting go of legalism: developing a 'thicker' version of transional justice, p. 16.

${ }^{226}$ MCEVOY, Kieran. Letting go of legalism: developing a 'thicker' version of transional justice, p. 18-28. Contra esse legalismo e suas manifestações, esse autor propõe uma gama de corretivos teóricos e práticos que envolvem um "encorajamento da humildade legal" ("encouraging legal humilty"), os "direitos humanos como desenvolvimento" ("human rights as development") e uma "criminologia da justiça transicional" ("criminology of transitional justice") (p. 29-43).

${ }^{227}$ No original: "Official transitional mechanisms generally are narrow in scope, focusing on particular forms of abuse, designated time frames, and specific categories of perpetrators. The field is also usually defined as criminal, either in terms of international law or according to the law of the affected state...This focus effectively sidelines the more common economic or social abuses". MERWE, Hugo Van Der. Delivering justice during transition, p. 117. Crítica nessa mesma linha encontra-se no texto: CAVALLARO, James; ALBUJA, Sebastián. The lost agenda: economic crimes and truth comissions in Latin America and beyond. In: MCEVOY, Kieran; MCGREGOR, Lorna (Ed.). Transitional Justice from Below: Grassroots Actvism and the Struggle for Change. Oxford; Portland: Hart, 2008. p. 121-141.
} 
Daí esse autor afirmar que a justiça transicional é, portanto, um termo conservador que geralmente incide apenas sobre vítimas e perpetradores de violência física. Indo além, afirma que, "na verdade, os mecanismos de justiça transicional têm sido seriamente criticados como uma forma de obscurantismo ideológico subjacente às injustiças sociais" ${ }^{, 228}$.

Expostos os traços gerais dessa crítica, passa-se agora a aprofundar alguns aspectos levantados que têm maior relevância para o argumento explorado nesse trabalho.

\subsubsection{A normatividade e a universalidade dos modelos}

Dentre as principais críticas dirigidas a essas formulações, destacam-se aquelas que apontam a normatividade e a universalidade que estas carregam, explícita ou implicitamente ${ }^{229}$. Isso porque, muitas vezes, apresentam-se as medidas transicionais, de inspiração marcadamente liberal-ocidentalizadora, como receitas de democratização formuladas a partir de modelos que poderiam ser implantados em realidades muito distintas entre si.

Nas reflexões mais recentes, têm-se problematizado esse modelo de justiça de transição que opera a combinação de mecanismos padrão preexistentes, de acordo com a conjuntura específica. Essa visão tradicional, de algum modo, termina reduzindo as possibilidades de uma experiência complexa e rica a uma espécie de "caixa ou kit de ferramentas" (“toolkit”) ${ }^{230}$, na qual os elementos universais estariam disponíveis para serem mobilizados, em combinações pré-concebidas, pelos diferentes atores em suas realidades locais. Essa é, precisamente, a via encontrada, pelos que têm se dedicado a esse

\footnotetext{
${ }^{228}$ No original: "Transitional justice is thus a conservative term that generally focuses only on victims and perpetrators of physical violence (...). Indeed, transitional justice mechanisms have been seriously criticized as a form of ideological obfuscation of underlying social injustices". MERWE, Hugo Van Der. Delivering justice during transition, p. 117.

${ }^{229}$ Também o idealismo aparece nas críticas: "Os mecanismos da justiça transicional são geralmente apresentados em termos muito idealistas, sem metas claramente definidas". No original: "transitional justice mechanisms are generally presented in very idealistic terms without clearly defined goals". MERWE, Hugo Van Der. Delivering justice during transition, p. 121.

230 "Ao contrário da visão tradicional de justiça de transição como uma caixa de ferramentas, contendo componentes pré-definidos concebidos como 'pilares', não deveríamos, enquanto profissionais, estar defendendo, ao invés dessa, uma reflexão sobre o tema da justiça de transição entendida de forma mais ampla e garantir que diversas vozes possam juntar-se a esse debate?". No original: "contrary to the vision of transitional justice as a toolkit containing the predefined components conceived of as 'pillars', should we not as practitioners be advocating instead for reflection on the subject of justice understood more broadly and ensure that diverse voices are able to join in the debate?". OKELLO, Moses Chrispus. Elevating transitional local justice or crystalizing global governance, p. 284.
} 
tema e pelos posicionamentos dos organismos institucionais, para conciliar a universalidade dos deveres morais e jurídicos internacionais com as contingências políticas de cada realidade particular. O problema é que as regras de mediação entre o universal e o particular não são bem trabalhadas, o que leva a um enorme casuísmo, que julga cada caso, arbitrariamente, dependendo da visão do observador.

Assim, alguns autores pontuam que é necessário retroceder um pouco para compreender melhor do que se está tratando. Isso porque entendem que "a busca de soluções e modelos também produziram respostas simplistas a um conjunto de problemas para os quais nós ainda não parecemos entender sequer a questão. Prover justiça geralmente significa coisas diferentes para pessoas diferentes. É, portanto, um debate altamente emotivo entre pessoas que falam diferentes linguagens conceituais" ${ }^{\text {"231 }}$.

Daí a elaboração, por esse autor, de uma interessante tabela que sistematiza alguns dos diferentes e possíveis sentidos da justiça diante das violações de direitos humanos. Ele destaca três perspectivas: a centrada no ofensor, no meio social e na vítima:

Tabela 2 - Objetivos da justiça por alvo ${ }^{232}$

\begin{tabular}{|c|c|c|c|}
\hline Objetivos & Ofensores & $\begin{array}{c}\text { Outros no meio } \\
\text { social }\end{array}$ & Vítimas \\
\hline $\begin{array}{c}\text { Controlar o } \\
\text { comportamento }\end{array}$ & $\begin{array}{l}\text { Dissuasão, } \\
\text { isolamento, } \\
\text { eliminação, } \\
\text { reparação às vítimas }\end{array}$ & $\begin{array}{l}\text { Dissuasão ou ameaça } \\
\text { geral, prevenção de } \\
\text { vingança por terceiros }\end{array}$ & $\begin{array}{l}\text { Prevenção da } \\
\text { vingança e da } \\
\text { ruptura social }\end{array}$ \\
\hline $\begin{array}{c}\text { Reafirmação } \\
\text { de valores e } \\
\text { crenças sociais }\end{array}$ & $\begin{array}{l}\text { Mudança do sistema } \\
\text { de crenças dos } \\
\text { ofensores vis-à-vis } \\
\text { às vítimas ou às } \\
\text { regras sociais, } \\
\text { afirmação do poder } \\
\text { sobre os ofensores, } \\
\text { envergonhando-os }\end{array}$ & $\begin{array}{l}\text { Reivindicar a lei, } \\
\text { reestabelecer o } \\
\text { consenso social sobre } \\
\text { as regras, manter a } \\
\text { crença no Estado e no } \\
\text { sistema legal }\end{array}$ & $\begin{array}{c}\text { Reafirmação da } \\
\text { autoimagem e } \\
\text { senso de controle } \\
\text { das vítimas e sua } \\
\text { crença na eficácia } \\
\text { do Estado e do } \\
\text { sistema legal }\end{array}$ \\
\hline
\end{tabular}

${ }^{231}$ No original: "the search for solutions and models has also produced simplistics answers to a set of problems for which we don't yet seem to understand the question. Delivering justice usually means different things to different people. It is therefore a highly emotive debate among people speaking different conceptual languages". MERWE, Hugo Van Der. Delivering justice during transition, p. 138.

${ }^{232}$ Adaptada de MERWE, Hugo Van Der. Delivering justice during transition, p. 122. Mas esse autor destaca que há muito espaço para o confronto e a complementariedade desses olhares contrastantes, nenhum deles sendo autossuficiente para compreender o fenômeno em sua integralidade. 
Assim, esse uso muitas vezes indiscriminado de um conceito de justiça a situações que pouco ou nada têm em comum, envolvendo atores de interesses tão diversos e muitas vezes contraditórios entre si, provoca um desgaste profundo desse modelo analítico, esvaziando seu conteúdo específico e seu caráter histórico.

Primeiro, porque as análises pretendem dar conta de mudanças de regimes políticos ocorridos desde a antiguidade clássica, passando pela França de Napoleão, pelos julgamentos internacionais pioneiros do pós-guerra, encontrando expressão privilegiada nas ditaduras sul-americanas, regimes protofascistas da Europa mediterrânea, na África do Sul pós-apartheid e na queda dos regimes da Europa do Leste, chegando, até mesmo, às guerras na Iugoslávia, aos conflitos armados na Colômbia e às recentes mobilizações deflagradas no Oriente Médio e outros países da região, naquilo que ficou conhecido como "Primavera Árabe". A lista de estudos empíricos abordados sob o viés dessa orientação teórica, nas obras coletivas existentes, é interminável e cresce a cada dia. Basta um rápido olhar nos índices para verificar a disparidade de contextos e conjunturas que são colocados lado a lado.

Em segundo lugar, concentrou-se em demasia na ideia geral de reparação das violações de direitos humanos, sem se preocupar, com a devida atenção, para as particularidades das diferentes formas de violação. Os estudos nesse campo mencionam, normalmente, tanto as situações pós-conflitivas (especialmente pós-guerras civis) quanto as pós-transicionais (pós mudança de regimes políticos). No entanto, essa diferenciação aparece apenas como análise empírica, sem que haja um quadro conceitual próprio que reflita as singularidades demandadas pelo conhecimento dessas distintas conjunturas. Pelo contrário, ainda são tratadas, via de regra, pelo mesmo esquema das quatro dimensões da justiça transicional: memória, verdade, justiça e reforma das instituições; ou por variações inexpressivas desse mesmo esquema.

Terceiro, essas reflexões têm sido aplicadas a países que passaram por transições ou por conflitos em diferentes períodos de sua história e que, portanto, encontram-se em estágios completamente distintos de seus desenvolvimentos políticos. Por exemplo, modular o mesmo conceito de justiça de transição para o Brasil - que já fez sua transição há décadas, para a Alemanha egressa do nazismo há mais de meio século e as recentíssimas experiências de mudanças políticas nos países árabes acarreta um inevitável esgarçamento do conceito e, sobretudo, uma confusão na compreensão dessas situações distintas. Mais do que isso, corre-se o risco bastante palpável e frequentemente 
concretizado de transpor-se pressupostos normativos de um contexto ao outro, apreciando valorativamente de modo equivocado os distintos processos e subestimando suas particularidades.

Nessa linha, alguns autores entendem que "todas essas abordagens continuam normativas, descritivas e esperançosas" ${ }^{, 233}$. Não deixam, entretanto, de reconhecer que esse modo de compreensão e de análise aportou importantes contribuições pontuais, a despeito de suas limitações de conjunto para a afirmação do conceito.

Consequentes com essa ponderação que dirigem à visão tradicional de justiça transicional e a suas variações, esses analistas afastam-se da concepção do fenômeno baseada antes nas preferências por mecanismos específicos e nas expectativas normativas do que em hipóteses efetivamente testadas e comprovadas. Trata-se de uma pretensão de conferir estatuto científico mais rigoroso aos novos estudos. Como solução, propõem-se a elaborar uma "teoria empiricamente fundada da justiça de transição" ("empirical grounded theory of transitional justice") ${ }^{234}$.

Colocação em sentido análogo é feita por Elster, para quem uma teoria normativa da justiça transicional esbarraria, necessariamente, nas peculiaridades dessas experiências que normalmente variam conforme o contexto temporal e espacial. Em suas próprias palavras, "a natureza contextual do fenômeno [é] um obstáculo insuperável a generalizações"235.

No entanto, para esse autor, a dificuldade em se estabelecer uma lei e uma teoria gerais sobre a matéria não impede a apreensão de algumas generalidades recorrentes em cada experiência, ou seja, "tentar identificar padrões recorrentes de comportamento",236. Buscando esvaziar a carga normativa, ressalva que tal perspectiva não implica, necessariamente, a universalização dos padrões particulares geralmente observados para todos os contextos de forma indiscriminada, o que prejudicaria o tratamento teórico adequado para o tema.

Desse modo, para compreender por que processos de justiça transicional assumiram formas distintas em diferentes transições, esse autor adverte que menos do que uma análise normativa, coloca-se como necessária uma análise explicativa ou positiva

\footnotetext{
${ }^{233}$ No original: "all of these approaches remain normative, descriptive, and hopeful". OLSEN, Tricia; PAYNE, Leigh; REITER, Andrew. Transitional Justice in balance, p. 25.

${ }^{234}$ OLSEN, Tricia; PAYNE, Leigh; REITER, Andrew. Transitional Justice in balance, p. 16.

${ }^{235}$ No original: "the context-dependence of the fenomena [is] an insuperable obstacle to generalizations". ELSTER, Jon. Closing the books, p. 77.

${ }^{236}$ No original: "triyng to identify recurring patterns of behaviour". ELSTER, Jon. Closing the books, p. 77.
} 
dessa questão. Daí considerar que "a análise da justiça de transição é parte dos estudos empíricos da justiça" 237 .

Mas nem todas as objeções dirigidas a esse campo conceitual estão centradas na normatividade das análises comumente feitas. Dentre os que se propõem a realizar investigações de natureza empírica nesse campo, emerge outra crítica quanto às perspectivas dominantes, que será examinada a seguir.

\subsubsection{Uma justiça de transição "desde baixo"}

Uma ponderação interessante e relativamente nova no que se refere à concepção mais institucionalizada da justiça de transição é a que caracteriza essa abordagem tradicional como "justiça de transição desde cima" ("transitional justice "from above") Em contraste com esse olhar dominante, esses autores pretendem destacar a participação da sociedade civil nesses processos, entendidos de forma ainda muito institucionais e, especialmente, estatais.

Explorado de forma mais consistente em coletânea recente, esse enfoque diferenciado, que se inspira declaradamente nos "estudos subalternos" ("subaltern studies"), consiste em analisar a "a justiça de transição "no chão" nas comunidades ou organizações que foram diretamente afetadas pelo conflito violento" ${ }^{\text {"239 }}$. O objetivo maior seria, desse modo, romper com o olhar "de cima para baixo".

Essa coletânea de textos visa ao que está "por baixo do olhar das instituições formais da justiça de transição", denotando o termo "from below', "um caráter resistente ou mobilizador das ações comunitárias, da sociedade civil e de outros atores não-estatais, na sua oposição às poderosas forças políticas, sociais e econômicas hegemônicas"240.

\footnotetext{
${ }^{237}$ No original: the analysis of transitional justice is part of the empirical studies of justice". ELSTER, Jon. Closing the books, p. 79 e 80.

${ }^{238}$ MCEVOY, Kieran; MCGREGOR, Lorna. Transitional Justice from Below: An agenda for research, policy and praxis. In: (Ed.). Transitional Justice from Below: Grassroots Actvism and the Struggle for Change. Oxford and Portland, Oregon: Hart, 2008. p. 5.

239 No original: "transitional justice 'on the ground' in the communities or organisations which have been directly affected by violent conflict”. MCEVOY, Kieran; MCGREGOR, Lorna. Transitional Justice from Below, p. 2/4.

${ }^{240}$ No original: "a 'resistant' or mobilising'character to the actions of community, civil society and other non-state actor in their opposition to powerful hegemonic political, social or economic forces". É importante ressaltar que não se trata de renegar ou rejeitar a importância dos estudos já realizados. Como esclarecem, "without exception, none of the papers adopts a simplistically rejectionist position towards the more
} 
Assim, ainda que não caiba aprofundar aqui os diversos estudos de caso realizados sob essa perspectiva, é importante reter que, para contemplar o ponto forte dessas críticas, deve-se preciso recuperar a relevância da sociedade civil e de suas mobilizações nos processos transicionais, atenuando a dimensão normativa do conceito.

Expostas essas críticas, é preciso pontuar aquela que, na perspectiva desse trabalho, a mais relevante ressalva ao conceito de justiça de transição é a que será exposta a seguir.

\subsubsection{Uma justiça excepcional ou ordinária?}

Como foi visto, a literatura produzida nesse terreno analítico da justiça transicional passa a questionar o que seria uma transição justa, o que inevitavelmente implica levar a sério certas referências morais e éticas, além de parâmetros jurídicos, que extrapolam e se impõem, de algum modo, à dinâmica típica dos jogos políticos.

O fato de a justiça tornar-se a principal preocupação desse novo campo de reflexões marca, sem dúvidas, uma ruptura e uma inovação em relação aos primeiros estudos sobre as transições. No entanto, se essas diferenças são bem sublinhadas e até reivindicadas nas reflexões sobre justiça de transição, por outro lado, são pouco lembradas as linhas de continuidade entre essas duas tradições, que têm mais em comum do que, à primeira vista, pode parecer.

Isso porque a justiça que interessa aos teóricos citados nesse capítulo não é aquela que serve de valor de referência nos períodos de estabilidade ou normalidade política. $\mathrm{O}$ enfoque dado é, justamente e como revela o próprio nome, na justiça nos momentos de transição, seja pós-autoritária ou pós-conflitiva.

Não se adota um conceito impunemente, sobretudo um conceito político de tanta complexidade como o de transição. Assim, é evidente que alguns pressupostos teorizados pelos transitólogos estejam presentes também nas discussões sobre justiça transicional. Particularmente, a incerteza constitutiva desses momentos, que demanda e até impõe um excepcionalismo metodológico, é o principal deles, pelas consequências importantes que implica.

traditional styles of transitional justice "from above"'. MCEVOY, Kieran; MCGREGOR, Lorna. Transitional Justice from Below, p. 5. Antes, trata-se de oferecer uma perspectiva que, em muitos casos, mostra-se privilegiada para a observação e compreensão de aspectos pouco valorizados pela abordagem tradicional (p. $3)$. 
O capítulo anterior buscou demonstrar que os momentos transicionais reconfiguram os traços e o funcionamento ordinários da política. Esta, na falta de regras e instituições bem definidas e estabilizadas, é tomada pelos atores políticos, que passam a ditar os rumos da comunidade política a partir de suas expectativas, cálculos e negociações. No entanto, essa liberdade não é ilimitada: sofre um constrangimento fundamental, característico e inevitável nesses momentos, que é a ameaça de uma regressão autoritária caso os interesses fundamentais residuais dos membros do governo autoritário sejam afetados.

Pois bem. Nesse cenário geral, discutido mais detidamente no capítulo anterior, assim como a política é particularizada pelas circunstâncias especiais, também a justiça sofre inflexões não menos importantes. Como caracteriza Pablo de Greiff, a transição é um "mundo muito imperfeito" ("very imperfect world") 241.

Nessa direção, a exemplo das limitações postas à política nessas conjunturas críticas, um de seus pontos mais complexos, a justiça, também é posta em perspectiva. Não por acaso, esta desempenhava papel secundário nas primeiras teorizações, pois poderia provocar um novo golpe a e "morte rápida" da democratização do regime.

Soma-se a isso o fato de que, normalmente, as demandas por uma justiça excepcional, para além dos mecanismos ordinários já estabilizados, são oriundas das próprias partes diretamente interessadas. Como afirma Merwe,

\begin{abstract}
a pressão para introduzir mecanismos especializados de transição (em vez de depender ou reforçar os mecanismos legais tradicionais) para lidar com crimes do passado vem de ambos os lados do conflito. Os responsáveis pelos abusos do passado colocam pressão para evitar que seus processos sejam julgados pelos tribunais regulares, argumentando que foram eventos incomuns em circunstâncias fora do comum, o que exigiu deles a ação fora da lei. Aqueles que foram submetidos aos abusos procuram um tratamento especial para seus casos, em grande medida porque o sistema legal sob o regime passado era incapaz ou não queria levar seus casos a sério (e os sistemas legais herdados muitas vezes têm falhas similares) (...). Este argumento da transição, em oposição à justiça 'normal' reflete uma batalha política para redefinir a moralidade dos atos do passado, mas também apresenta um desafio para a legitimidade e a eficácia do sistema legal herdado (...) Além de simplesmente avaliar os mecanismos de justiça de transição, há uma necessidade de colocar esta análise dentro de um amplo quadro de justiça durante a transição ${ }^{242}$.
\end{abstract}

\footnotetext{
${ }^{241}$ Para esse autor, esse mundo muito imperfeito é aquele em que não há observância espontânea e generalizada às normas legais e morais, e fazer cumprir a lei é muito custoso. No original: "A very imperfect world is one in which there is no spontaneous generalized compliance ... and trying to enforce the law is very costly". GREIFF, Pablo. International courts and transitions to democracy. Public Affairs Quarterly, v. 12, n. 1, p. 79-99, jan. 1998. Disponível em: <http://www.jstor.org/pss/40436007>. Acesso em: 20 dez. 2011 . p. 79. ${ }^{242}$ MERWE, Hugo Van Der. Delivering justice during transition, p. 118 e 119. No original: "the pressure to introduce specialized transitional mechanisms (rather than relying on or bolstering traditional legal mechanisms) to deal with past crimes comes from both sides of the conflict. Those responsible for past abuses apply pressure to avoid having their cases heard by the regular courts, arguing that these were unusual
} 
Esse autor destaca um aspecto fundamental. A demanda por uma justiça extraordinária significa não apenas uma disputa pela moralidade dos atos do passado, mas coloca o desafio de legitimar a reconstrução de um sistema legal do passado, contextualizando essa reflexão dentro de um quadro mais amplo. A questão que se coloca é, precisamente, como reestabelecer um senso de justiça a partir de iniciativas de caráter contingente e excepcional.

Avançando nesse aspecto e negando radicalmente a necessidade de mecanismos extraordinários de uma justiça também concebida para uma ocasião especial, Posner e Vermeule questionam essa literatura que identifica dilemas jurídicos, morais e institucionais próprios de uma suposta justiça de transição.

Para esses autores, essa visão tradicional se equivoca não por inadequação moral ou política, mas antes porque "preservam uma imagem estereotipada da justiça ordinária" como se esta fosse sempre prospectiva, na qual os indivíduos sempre conseguiriam obter, sem custos, compensações para todos os danos pessoais ou patrimoniais causados por terceiros e que as transições nunca ocorreriam nesse contexto normal, pois o sistema legal funciona perfeitamente em equilíbrio ${ }^{243}$.

Por outro lado, contrariando essa visão, esses autores sugerem que a justiça ordinária rotineiramente lida com mudanças políticas causadas por choques econômicos e tecnológicos, bem como por mudanças de valores dos cidadãos e das elites jurídicas. Afirmam que essa descontinuidade também coloca problemas transicionais e que, portanto, a legislação ordinária tem condições de lidar com esses problemas mantendo ordem social, assegurando estabilidade de expectativas e ocasionalmente satisfazendo as aspirações por justiça $^{244}$.

events in unusual circunstances, which required them to act outside the law. Those who were subjected to abuses look for special treatment of their cases largely because the legal system under the past regime was unable or unwilling to take their cases seriously (and the inherited legal systems often have similar flaws) (...) This argument for transitional as opposed to 'normal' justice reflects a political battle for redefining the morality of past acts but also presents a challenge to the legitimacy and efficacy of the inherited legal system (...) Beyond merely assessing transitional justice mechanisms, there is a need to place this analysis within a broader justice during transition framework".

${ }^{243}$ No original: "they have erred, not by virtue of inadequate moral or political analysis, but by holding a stereotyped picture of ordinary justice, one in which all laws are always prospective, individuals costlessly obtain compensation for all harms to person or property inflicted by others, and transitions essentially never occur because the legal system runs smoothly in settled equilibrium". POSNER, Eric; VERMEULE, Adrian. Transitional justice as ordinary justice. Public Law and Legal Theory Paper Working Paper, p. 3.

${ }^{244}$ No original: "In our picture, by contrast, ordinary lawmaking must routinely cope with policy shifts caused by economic and technological shocks and by changes in the value judgments of citizens and legal elites. These jarring discontinuities predictably create transition problems. The law has developed a range of pragmatic tools for managing such problems while maintaining social order, ensuring some stability of expectations, and occasionally aspiring to see justice done. None of this commits us to defending all of the law's pragmatic tools of transition-management, which are in some cases excessively crude, inadequately 
A conclusão que esses autores extraem dessa compreensão da justiça de transição enquanto justiça ordinária é interessante. Eles entendem que, por se tratar de algo ordinário, não há razão para tratar as medidas transicionais como suspeitas, seja da perspectiva moral ou institucional, a menos que os sistemas de justiça ordinários também fossem tratados com essa suspeição. Com esse argumento, esses autores afastam parte importante das críticas dirigidas à justiça de transição, que a qualificam como não liberal e retroativa ${ }^{245}$. Em verdade, todos os sistemas legais enfrentam problemas transicionais, não havendo razão para operar uma distinção tão rígida entre a justiça de transição enquanto paradigma e a justiça ordinária. A normalização da justiça de transição enquanto política pública também parece reforçar a argumentação desses autores.

No entanto, apesar dessa ponderação, é inegável que prevalece uma visão da justiça de transição enquanto algo excepcional e extraordinário, mais especificamente, pode-se dizer, como algo que nasce do cruzamento da possibilidade com a necessidade.

\subsubsection{Uma justiça de compromisso: entre a necessidade e a possibilidade}

Um paradoxo comumente referido para tratar da justiça de transição é o de que nos momentos em que a justiça é mais necessária, parece tornar-se mais difícil de atingi$1 \mathrm{a}^{246}$. Quanto mais indispensável, ela pareceria também mais inalcançável. Isso significa

theorized, or defended on specious grounds. But it should explode the assumption that transitional justice is a distinctive topic that presents a distinct set of moral and jurisprudential dilemmas". POSNER, Eric; VERMEULE, Adrian. Transitional justice as ordinary justice. Public Law and Legal Theory Paper Working Paper, p. 4.

${ }^{245}$ No original: "Our second claim results from the first. Given that transitional justice is continuous with ordinary justice, there is no reason to treat transitional-justice measures as presumptively suspect, on either moral or institutional grounds, unless we are to treat the justice systems of nontransitional liberal democracies as suspect as well. The dominant instinct among academic commentators on transitional justice is to condemn transitional-justice measures wholesale, either on the ground that transitional measures are retroactive and thus inherently illiberal, or on the closely associated ground that new regimes should reserve their energies exclusively for forward-looking measures of state- building, economic growth, and the development of political cohesion. But this posture is no more coherent than would be a parallel condemnation of all the measures that legal systems ordinarily use to manage change. In any legal system, we will argue, transition problems are inevitable; retrospective measures themselves have important forwardlooking justifications; and to forego any retrospective measures is an implausibly extreme solution to the transition problem, one that very few new regimes have adopted. The attempt to eschew transitional measures is itself a transitional measure, and usually a poor one. There will of course be good pragmatic reasons to object to particular transitional schemes, programs and measures, and we will provide pragmatic evaluations as the discussion proceeds. There is no global reason, however, to treat transitional justice as suspect". POSNER, Eric; VERMEULE, Adrian. Transitional justice as ordinary justice. Public Law and Legal Theory Paper Working Paper, p. 4.

${ }^{246}$ CUEVA, Eduardo González. Perspectivas teóricas sobre la justicia transicional, p. 6. 
dizer que a justiça de transição é, sem dúvidas, uma justiça do possível, imposta por normas internacionais na maior parte das vezes vinculantes aos Estados, mas efetivamente viabilizada por determinadas correlações de forças. A despeito da importância que o direito passa a ter, fato é que a natureza contingente da política permanece presente, ainda que com esse balizamento jurídico.

Daí decorre a afirmação, bastante precisa, de que "nas transições e na literatura sobre justiça de transição, programas híbridos geralmente são compromissos nascidos da necessidade" 247 . Ou seja, são conjunturas críticas em que predominam constrangimentos incontornáveis, diante dos quais, somente mediante compromissos e negociações, necessariamente com concessões recíprocas, é possível atingir algum grau de justiça. No entanto, sempre restará, como um dado marcante e impossível de ser apagado, um déficit ou uma falta de justiça, que será justificada, na visão dominante, pela natureza contingente da concretização dessas demandas. Justamente a partir dessas lacunas é que se desenvolverão os mecanismos alternativos à justiça ordinária e já tradicionalizados da justiça de transição ${ }^{248}$.

Desse modo, a teoria sobre a justiça de transição, portanto, coloca-se como "um exercício de teoria não-ideal", que deve levar em conta as circunstâncias únicas que são encontradas nas transições e nos regimes precedentes para construir um paradigma de direito transicional ${ }^{249}$.

Em outros termos, nos momentos transicionais, justamente por não ser possível a efetivação do valor de justiça em sua integralidade ou em sua plenitude - até o ponto em que é correto falar isso -, é que surgiu o conceito de justiça de transição para dar conta dessa realidade bastante particular e excepcional. Nesses momentos, é preciso conciliar demandas por justiça, garantidas pelo sistema jurídico e legitimadas pela dimensão ética, com imperativos de estabilidade de ordem política. Não é equivocado, portanto, sustentar que a justiça de transição é uma justiça de exceção ou, melhor explicando, uma negação da própria justiça, que só se efetiva parcialmente de acordo com a lógica do que é possível.

\footnotetext{
${ }^{247}$ No original: "In transitions, and in transitional justice literature, hybrid programs usually are compromises born of necessity". GRAY, David. An excused-centered approach to transitional justice, p. 2622.

248 "A falta de justiça que se abre nas transições é preenchida, mais frequentemente, com teorias alternativas de justiça e procedimentos alternativos, como as comissões da verdade". No original: "The justice gap that opens in transitions is filled most frequently with alternative theories of justice, such as restorative justice, and alternative procedures, such as truth commissions". GRAY, David. An excused-centered approach to transitional justice, p. 2628.

${ }^{249}$ No original: "Transitional justice is an exercise in "nonideal" theory. As such, it must take positive account of the unique circumstances found in transitions and their predecessor regimes in constructing a transitional jurisprudence”. GRAY, David. An excused-centered approach to transitional justice, p. 2623.
} 
Nesse sentido, vale transcrever a opinião de Hugo Merwe, para quem "pode-se supor que "os mecanismos de justiça de transição" visam às demandas de justiça pelos abusos do passado. Mas essa é uma suposição otimista e nem sempre correta. Às vezes, esses mecanismos oferecem canais diretos para a busca de justiça, mas, frequentemente, eles fazem mais para limitar o alcance da justiça. Justiça durante a transição é, muitas vezes, definida por sua negação: a concessão de anistia e outros métodos de limitar a prestação da justiça ${ }^{250}$.

Diversas são as limitações concretas existentes para que sejam implementados programas de justiça durante os momentos excepcionais: recursos materiais, técnicos, humanos etc. Alguns autores argumentam que, em se tratando de recursos escassos em sociedades que vivem situações extremas, há diversos fatores que influenciam e até obstruem as possibilidades de justiça. Nessa linha, Kritz afirma que "embora uma escolha do instrumento de justiça transicional não deva ser uma decisão de soma zero, a realidade para as sociedades de transição é que os recursos disponíveis são limitados (...). Para os países que emergiram de guerras civis devastadoras ou de regimes corruptos e repressivos duradouros, os recursos humanos e materiais são extremamente limitados"251.

Por isso a afirmação realista de Juan Méndez, no sentido de que "o fato de haver fortes argumentos morais e legais para o processamento dos perpetradores das violações aos direitos humanos não elimina as enormes dificuldades políticas que uma política dessa natureza enfrenta diante da delicada correlação de forças que caracteriza a maioria das transições" 252 .

Mas, logo adiante, esse mesmo autor faz questão de ressaltar que "uma apreciação realista e sóbria das realidades políticas não constitui, automaticamente, um argumento para a inação. A resistência que os criminosos demonstram para qualquer forma de accountability e particularmente suas ameaças para desestabilizar a transição não podem

\footnotetext{
${ }^{250}$ No original: "one might assume that 'transitional justice mechanisms' refers to a process addressing the demand for justice for past abuses. But this is an optimistic assumption and not always correct. Sometimes these mechanisms provide direct channels for pursuing justice, but often they do more to limit the scope of justice. Justice during transition is often mainly defined by its negation: the provision of amnesty and other methods of limiting the delivery of justice". MERWE, Hugo Van Der. Delivering justice during transition, $p$. 115 .

${ }^{251}$ No original: "although a choice of transitional justice instrument should not be a zero-sum decision, the reality for transitional societies is that available resources are limited (...). For countries emerging from devastating civil wars or long-term corrupt and repressive regimes, both human and material resources are extremely limited. KRITZ, Neil. Policy implications of empirical research on transitional justice, p. 20 e 21. ${ }^{252}$ No original: "the fact that there are strong legal and moral arguments in favour of prosecuting former human rights abusers does not eliminate the enormous political difficulties that such a policy faces in the delicate balance of powers that characterizes most transitions". MÉNDEZ, Juan E. In defense of transitional justice, p. 8 e 9 .
} 
ser aceitas para determinar a política governamental. Ser complacente com essas pressões apenas significa deixar a democracia ser chantageada e começar o período transicional em terreno movediço (...) esse tipo de chantagem corrói a autoridade democrática"253.

Assim, "a justiça requer que um cuidadoso equilíbrio seja atingido entre garantir que um processo seja 'legítimo' aos olhos das elites políticas internas, ou mesmo da população em geral, e que seja 'legítimo' para as vítimas. Os processos de justiça transicional, em todos os lugares, são atormentados pela escassez de financiamento, politicamente por mandatos temporais curtos, estatutos de limitação e interesses conflitantes que restringem o seu alcance e eficácia geral. Mesmo com tais limitações, no entanto, eles podem alcançar a justiça se criar em espaço suficiente, aos que sofreram, para que se sintam como se tivessem uma oportunidade significativa para fazer parte do

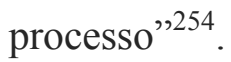

Para utilizar outras palavras, a busca é pela "melhor justiça possível”, dada as condições adversas em que se está pensando a justiça. Por isso Gray sustenta, em trecho longo que vale a transcrição, que "transições devem se contentar com a melhor justiça possível, dadas as circunstâncias imperfeitas. Alguns têm caracterizado os suspiros que acompanham essa visão como uma reação histérica exagerada, confundindo os desafios práticos à justiça em transições com obstáculos intransponíveis em vez de simples variações de desafios alarmistas entre aqueles interessados na justiça de transição. É verdade que confrontados com os compromissos nascidos da necessidade, a maioria dos teóricos da justiça de transição demonstram pesar compreensível de que "mais" justiça não pode ser feita, mas lamentar que mais não pode ser feito não é o mesmo que desistir inteiramente da justiça"255.

\footnotetext{
${ }^{253}$ No original: "a realistic and sober appreciation of political realities does not automatically constitute an argument for inaction, The resistance that criminals might show to any form of accountability, and particularly their threats to destabilize the transition, cannot be allowed to determine government policy. Yielding to these pressures only amounts to letting democracy be blackmailed and starts the transitional period on shaky ground (...) this sort of blackmail undermines democratic authority”. MÉNDEZ, Juan E. In defense of transitional justice, p. 8 e 9.

${ }^{254}$ No original: "justice requires that a careful balance be struck between ensuring that a process is 'legitimate' in the eyes of internal political elites, or even the populace at large, and that it is "legitimate" to the victims. Transitional justice processes everywhere are plagued by funding shortages, politically mandated short timetables, statutes of limitation, and competing interests that limit their reach and overall effectiveness. Even with such limitations, however, they can achieve justice if they create enough espace for those who suffered to feel as though they had a meaningful opportunity to take part in the process". LUTZ, Ellen. Transitional justice: lessons learned and the road ahead. In: ROHT-ARRIAZA, Naomi; MARIEZCURRENA, Javier (Ed.). Transitional justice in the twenty-first century: beyond truth versus justice. New York: Cambridge University, 2008 [2006]. p. 338.

${ }^{255}$ No original: "Transitions must settle for the best justice possible given imperfect circumstances. Some have caracterized the sighs that accompany this view as hysterical overreaction, mistaking the practical challenges to justice in transitions for insurmountable obstacles rather than simple variations of challenges
} 
Isso significa dizer que o "temor onipresente" de um golpe, fator que determinava praticamente de forma exclusiva as movimentações dos atores durante as transições, não é mais considerado da mesma maneira. Ainda que seja um dado importante para manter o processo transicional, há outras motivações que começam a ser levadas a sério. Pois é preciso que a preocupação política esteja conjugada com um patamar ético e jurídico mínimo, em especial no que concerne aos direitos das vítimas e de seus familiares.

No entanto, por quanto tempo dura essa indefinição? Se o momento transicional é extraordinário e excepcional, qual período temporal necessário para a normalização de um regime político, com regras estáveis e procedimentos previsíveis? E, em um regime estabilizado, o que ocorre com a ideia de uma justiça de transição? Ela mantém sua pertinência?

Essas são questões que serão examinadas no terceiro capítulo.

handwringers among those interested in transitional justice. It is true that faced with the compromisses born of necessity most transitional justice theorists express understandable regret that "more" justice cannot be done, but regretting that more cannot be done is not the same as giving up on justice entirely". GRAY, David. An excused-centered approach to transitional justice, p. 2622. 


\section{A JUSTIÇA ENTRE A TRANSIÇÃO E A CONSOLIDAÇÃO: A EXCEÇÃO E A REGRA}

Nesse capítulo, serão retomados alguns autores examinados no capítulo primeiro, a fim de compreender quando se encerra um momento transicional e suas diferentes fases. Em seguida, será discutido o estágio da consolidação democrática e as implicações que essa evolução tem para o conceito de justiça de transição.

\subsection{Estágios da transição: liberalização e democratização}

Como foi visto, ao contrário do que comumente se supõe, as transições não são momentos pontuais, mas processos que se arrastam no tempo e encadeiam diversos acontecimentos diferentes e, muitas vezes, até contraditórios entre si. São fenômenos complexos, que conjugam questões de diversas ordens postas pelas mudanças políticas quando desencadeadas.

No entanto, para os autores tratados no primeiro capítulo, ainda que a transição seja concebida como algo mais do que a passagem linear e previsível entre polos previamente determinados, é presumido um caminho natural ou, ao menos, desejável nos processos transicionais. Há, evidentemente, pressupostos de ordem normativa que orientam a linha evolutiva traçada pelos transitólogos ${ }^{256}$, caracterizada por dois marcos

\footnotetext{
${ }^{256}$ O’Donnell assume de maneira bastante expressa essa orientação normativa: “A implantação da democracia política, tanto no plano da competição, através da autoridade e sua transferência, como da vigência de direitos humanos individuais básicos e associativos, é, do ponto de vista normativo em que me coloco, um imenso progresso com relação às características da vigência do estado burocrático-autoritário". O’DONNELL, Guillermo. Contrapontos, p. 78. Schmitter e Karl sistematizam bem essa ideia de que a democratização não traz, necessariamente, em seu rastro, crescimento econômico, paz social, eficiência administrativa, harmonia política, liberdade de mercados ou o fim da ideologia. Ainda que essas características possam facilitar a consolidação democrática, o que se pode esperar de um regime democrático é a emergência de instituições políticas capazes de competir pacificamente para formar governos e
} 
fundamentais e sucessivos, que seriam os momentos constitutivos de uma transição política ideal-típica. São eles a liberalização e a democratização ${ }^{257}$.

À primeira vista, sobretudo pela associação comumente feita entre liberalismo e democracia, soariam idênticos entre si. Até mesmo porque se referem ambos a medidas concretas de abertura política de regimes autoritários, assumindo importância e significados distintos em cada contexto particular. Distingui-los, por essa razão, demanda uma análise detida desses fenômenos intimamente vinculados entre si e que, na prática, chegam a manifestar-se simultaneamente.

No entanto, há um esforço deliberado, nessa tradição, em ressaltar as diferenças entre esses momentos e a complexa relação existente entre eles. Essa preocupação justifica-se pela necessidade de frisar que há uma diferença de natureza e de grau entre as medidas de abertura ou relaxamento de um regime autoritário, bem como de afirmar uma valorização da democracia em si mesma como um fim. Em outras palavras, esses autores buscam demonstrar, para a tipologia que propõem, que nem toda e qualquer iniciativa de distensão representa uma busca real de democracia política, como se verá a seguir.

\subsubsection{O primeiro passo: a liberalização do regime}

A liberalização consiste no momento inicial da transição, no qual se desencadeia um processo de redefinição e de extensão de direitos, em que apenas algumas liberdades parciais e restritas, típicas do liberalismo clássico, seriam salvaguardadas. Dentre essas “conquistas civilizatórias", pode-se apontar as "liberdades de expressão, organização e participação políticas” ${ }^{258}$. Nesse tipo de situação, o regime autoritário diminui o nível de repressão e passa a tolerar um determinado grau de expressão política da oposição, desde que dentro de limites previamente estabelecidos. Não se coloca em questão, efetivamente, a continuidade estrutural do regime, razão pela qual Przeworski qualificará os projetos de

influenciar as políticas públicas, bem como de estabelecer procedimentos regulares para os conflitos sociais e econômicos. Cf. SCHMITTER, Philippe C.; KARL, Terry L. What democracy is ... and is not. In: DIAMOND, Larry; PLATTNER, Marc F. (Ed.). The global resurgence of democracy. Baltimore: The Johns Hopkins University, 1993. p. 49 - 51.

257 A consolidação democrática é tida, nessa tradição, como um fenômeno distinto e autônomo em relação à transição, como será examinado mais adiante.

${ }^{258}$ SANTOS, Wanderley Guilherme dos. O século de Michels, p. 104 
liberalização, conduzidos normalmente pelo establishment autoritário, de "aberturas controladas do espaço político" 259 .

Esse mesmo autor qualifica a liberalização como uma situação de instituição de liberdades civis que não chegam a transformar, no entanto, o aparato de poder. Tampouco atinge aquela que é uma capacidade típica dos regimes autoritários, qual seja, a de controlar as consequências ex post das decisões políticas, revertendo seus resultados e manipulando tanto os procedimentos adotados quanto os conteúdos substantivos ${ }^{260}$.

De algum modo, a liberalização opera em meio às múltiplas combinações intermediárias possíveis entre dois extremos típico-ideais: um regime absolutamente autoritário e um modelo exemplar de democracia política. Assim, a liberalização pode operar sem que haja uma subversão do regime, mas apenas alterações tópicas nas institucionalidades política e jurídica. As mudanças previstas em um projeto de liberalização, portanto, têm dois traços característicos: são necessariamente superficiais e pontuais. Isso porque, normalmente, o projeto dos liberalizadores é aliviar a tensão política e o déficit de legitimidade por meio da ampliação da base social do regime, o que é feito permitindo alguma organização autônoma da sociedade civil e incorporando novos grupos nas instituições autoritárias existentes.

Esse caminho inicial pode levar tanto a uma efetiva transição do regime autoritário para um outro mais aberto e democrático, quanto para uma elevação do nível de repressão, dependendo das escolhas feitas durante esse processo ${ }^{261}$. Não por acaso, como lembra Przeworski, as expressões utilizadas para se referir às liberalizações de um regime autoritário são "abertura", "distensão", "afrouxamento da rosca" ou reconstrução (perestroika, "reforma", como a de uma casa). Todos esses termos têm fortes conotações de limites às reformas e de, no fundo, manterem determinado status quo ${ }^{262}$.

Contudo, o controle sobre o alcance da liberalização e seus limites não significa que essas mudanças tópicas sejam cosméticas e que suas consequências não sejam significativas para o jogo político e, sobretudo, para os próprios atores que recobram determinados direitos e garantias. Não é essa a perspectiva desses autores, que muitas vezes emplacam lutas políticas duras e intensas para lograr avanços nessas bandeiras. Por isso, normalmente reconhecem que, muitas vezes, a aquisição de certas liberdades básicas

\footnotetext{
259 PRZEWORSKI, Adam. Como e onde se bloqueiam as transições para a democracia?, p. 26.

260 PRZEWORSKI, Adam. Amas a incerteza e serás democrático, p. 37.

${ }^{261}$ Nas palavras de Przeworski, "liberalization [is] an opening that results in the broadening of the social base of the regime without changing its structure... Some misperceptions lead liberalization to transition; others, to repression" (PRZEWORSKI, Adam. Democracy and Market, p. 66).

262 PRZEWORSKI, Adam. Como e onde se bloqueiam as transições para a democracia?, p. 26.
} 
e direitos fundamentais é capaz de produzir um efeito multiplicador e determinante nos rumos de uma transição para a democracia, inaugurando um caminho que poderá ser trilhado por outros passos seguintes.

Entre a manutenção do regime autoritário absolutamente fechado e a sua completa abertura, há uma série de pontos marcados por distintos graus de liberalização, razão pela qual Luciano Martins afirmou que "a liberalização seria uma medida da intensidade da transição"263. Também O’Donnell e Schmitter compartilham essa visão de liberalização, essencialmente, enquanto uma questão de grau ${ }^{264}$.

Dessa forma, algumas iniciativas liberalizantes são bastante conhecidas: menor grau de censura à imprensa, liberdade pouco maior de organização e ação da classe operária, reintrodução de algumas salvaguardas legais e individuais no ordenamento jurídico, tais como habeas-corpus, a libertação da maioria dos prisioneiros políticos, o retorno dos exilados políticos e a tolerância da oposição política ${ }^{265}$. Como se nota, todas elas passíveis de aceitação em um regime autoritário, desde que mantidos outros traços fundamentais de fechamento do sistema político e de restrição parcial das garantias civis.

Assim, na liberalização, trata-se essencialmente "de tornar efetivos determinados direitos que protejam tanto os indivíduos como os grupos sociais de atos arbitrários ou ilegais cometidos pelo Estado ou por uma terceira parte" ${ }^{266}$. O’Donnell chega a caracterizar a liberalização como o processo segundo o qual há uma "significativa abertura do regime burocrático-autoritário", ainda que distante de uma verdadeira democracia política, destacando-se medidas como a garantia judicial a certos direitos individuais e a implantação de formas parlamentares mesmo ausente a livre competição eleitoral ${ }^{267}$.

\subsubsection{O segundo passo: a democratização}

A liberalização, dessa maneira, tem por traço principal o seu alcance limitado do ponto de vista da abertura de um regime autoritário. Representa, sem dúvidas, uma

\footnotetext{
${ }^{263} \mathrm{O}$ autor escreve, ainda, que os problemas práticos que é necessário enfrentar têm relação, em primeiro lugar, com a natureza e a dimensão das mudanças introduzidas no regime (o grau de liberalização) e, em segundo, com a dinâmica do processo político durante a transição (uma dinâmica que tem como base a relação entre a intensidade da crise e a capacidade do regime de enfrentá-la). MARTINS, Luciano. A "liberalização" do regime autoritário no Brasil, p. 113.

264 O’DONNELL, Guillermo; SCHMITTER, Philippe C. Transições do regime autoritário, p. 27.

265 STEPAN, Alfred. (Org.). Democratizando o Brasil, p. 13.

266 O’DONNELL, Guillermo; SCHMITTER, Philippe C. Transições do regime autoritário, p. 24.

267 O’DONNELL, Guillermo. Contrapontos, p. 97.
} 
melhora relativa das condições de vida e do grau de liberdade, mas não altera a natureza do regime. Por sua vez, a democratização é um momento mais avançado e expressivo do ponto de vista da garantia de direitos e de liberdades públicas comparativamente à liberalização, por demandar uma efetiva transformação do próprio regime político autoritário. Não basta, nesse caso e sob a perspectiva dessa tradição, apenas uma atuação limitada da oposição política, mas é preciso haver a possibilidade de uma contestação aberta pelo direito de assumir o controle do governo, o que demanda a forma das eleições livres, cujo resultado determinará quem governa ${ }^{268}$.

A democratização remete, portanto, à realização da própria ideia de democracia política. Aliás, a teoria das transições demanda uma definição razoavelmente precisa do que se entende por democracia, pois este seria o desfecho padrão - ao menos nos casos analisados - e desejado de uma transição política. Por isso, é preciso deter a análise com maior atenção sobre esse ponto.

\subsubsection{Mas qual democracia?}

Logo de início, deve-se advertir que, nesse conjunto de análises, não existe de forma expressa uma definição única de democracia, compartilhada de forma literal e deliberada por todos esses autores. No entanto, no interior do amplo debate em torno do sentido da democracia política, uma análise mais detida revela que eles podem ser filiados a uma concepção schumpeteriana mediada pelas elaborações de Robert Dahl, como é possível inferir a partir das principais instituições e regras que enumeram como requisitos políticos para a caracterização desse regime.

Schumpeter formulou uma das mais importantes definições modernas de democracia. Ele partiu de uma crítica contundente à doutrina política clássica, segundo a qual o método democrático seria "o arranjo institucional para chegar-se às decisões políticas que tornem real o bem comum, ao fazer com que o povo, por si mesmo, decida suas questões através da eleição de indivíduos a fim de cumprir sua vontade"269.

\footnotetext{
268 STEPAN, Alfred (Org.). Democratizando o Brasil, p. 13.

269 Segundo Schumpeter, essa é a concepção tradicional de democracia. No original: "The democratic method is that institucional arrangement for arriving at political decisions which realizes the common good by making the peopel itself decide issues through the election of individuals who are to assemble in ordem to carry out its will”. SCHUMPETER, Joseph A. Capitalism, socialism and democracy. 3. ed. New York: Harper \& Brother, 1950. p. 250.
} 
Ainda para esse autor, a concepção utilitarista tradicional é equivocada, por partir de elementos como a vontade do povo ("common will”), o bem comum ("common good") e outros valores superiores ("ultimate values"). Dentre outros argumentos, sustenta que contrariam os fatos essas suposições abstratas de uma natureza humana racional, com indivíduos conscientes, perseguindo seus respectivos interesses e compondo uma vontade geral determinável ${ }^{270}$.

Rompendo, assim, com essa definição que considera a fonte (vontade geral) e o propósito ("bem comum”) desse tipo de regime, Schumpeter propõe outra leitura. Na sua visão processual, a democracia deveria ser vista como um método baseado no arranjo institucional para chegar-se a decisões políticas em que os indivíduos adquirem o poder de decidir através de uma luta competitiva pelos votos do povo ${ }^{271}$.

Segundo esse autor, essa definição apresentaria diversas vantagens comparativamente àquela exposta anteriormente. Primeiro, oferta um critério de diferenciação dos regimes democráticos em relação aos demais tipos de governo, algo inviável à luz da teoria clássica; segundo, reconhece o dado vital da liderança no campo da política; terceiro, preserva as vontades concretas, sem abstrações, que serão mobilizadas por algum líder que as converter em fatores políticos relevantes; quarto, define o conceito de competição pela liderança a partir de uma útil comparação com a esfera econômica; quinto, parece esclarecer a relação entre democracia e liberdade individual; sexto, a função primordial do eleitorado é constituir um governo - pode também forçá-lo ou mesmo expulsá-lo -, mas isso é contrário ao método democrático; por fim, em sétimo lugar, essa teoria pode iluminar aspectos controversos antigos da doutrina clássica, sobretudo porque a vontade da maioria não é a vontade do povo, superando essa distorção ${ }^{272}$.

De forma bastante resumida, tendo em vista as limitações do presente trabalho, pode-se considerar que os elementos centrais dessa formulação schumpeteriana baseiam-se em uma noção de competição que dialoga diretamente com uma ideia econômica de mercado, mas passando a ser vista sob a ótica política. Nesse linha, a democracia não seria mais do que um mecanismo institucional e procedimental que permite que os votantes escolham e autorizem os regimes e seus governos. Assim, a política real é tida como uma atividade que cabe, primordialmente, às elites dirigentes, que são os únicos grupos que

\footnotetext{
${ }^{270}$ Cf. SCHUMPETER, Joseph A. Capitalism, socialism and democracy, p. 250-268.

271 "The democratic method is that institutional arrangement for arriving at political decisions in which individuals acquire the power to decide by means of a competitive struggle for the people's vote". SCHUMPETER, Joseph A. Capitalism, socialism and democracy, p. 269.

272 SCHUMPETER, Joseph A. Capitalism, socialism and democracy, p. 270-272.
} 
competem de maneira efetiva. Ao eleitorado, cabe apenas votar naqueles que decidirão sobre os problemas da política. Por essas razões, alguns autores mais críticos qualificam essa visão como a de um "modelo elitista pluralista de equilíbrio"273.

Inspirado também por essa formulação mais geral, ainda que com diferenças importantes, Dahl realiza uma reflexão fundamental em defesa do realismo político e de sua autonomia enquanto campo próprio da vida social, inclusive para a análise da mudança de regimes. Ele trabalha seu conceito de democracia a partir de regras que designa como "requirements for democracy", que seriam típicas, mas sem a pretensão de exaurir a complexidade que esse tipo de regime político carrega. Nessa perspectiva, partindo de dois traços fundamentais de uma poliarquia (o modelo ideal da democracia), que são a participação e a contestação ${ }^{274}$, estabeleceu um rol mínimo de características necessárias e suficientes para classificar um regime como democracia. Traçou algumas condições básicas que poderiam permitir a existência de uma democracia: 1) eleição de governantes; 2) eleições livres, frequentes e limpas (voto secreto); 3) sufrágio universal; 4) direito de concorrer aos cargos eletivos (competição partidária); 5) liberdade de expressão; 6) pluralismo de fontes alternativas de informação, protegido por lei; 7) direito de associação e liberdade de organização, incluindo partidos políticos; 8) instituições para fazer com que as políticas governamentais dependam de eleições e de outras manifestações de preferência $^{275}$.

$\mathrm{Na}$ esteira desses elementos básicos, toda a literatura que está sendo analisada supõe, para a configuração de uma democracia, que haja um acordo precedente e fundamental entre os atores políticos no que se refere à luta pelo poder, sem os poderes de

\footnotetext{
273 “(...) las tres características le son igualmente esenciales. Es pluralista en el sentido de que parte del supuesto de que la sociedad a la que debe adaptarse un sistema político democrático moderno es una sociedad plural, es decir, una sociedad formada por individuos cada uno de los cuales se ve atraído en muchas direcciones por sus diversos intereses, unas veces en compañia de un grupo de sus congéneres, otras veces en la de otros. Es elitista en el sentido de que asigna el papel principal en el proceso político a grupos de dirigentes que se escogen a sí mismos. Es un modelo de equilibrio en el sentido de que mantiene el equilibrio entre la oferta y la demanda de mercaderías políticas". MACPHERSON, Crawford Brough. La democracia liberal y su epoca. Buenos Aires: Alianza, 1991. p. 96.

${ }^{274}$ Nas palavras desse autor, "we think of democratization as made up of at least two dimensions: public contestation and the right to participate". DAHL, Robert. Poliarchy: participation and opposition. London: Yale University, 1971. p. 5.

${ }^{275}$ DAHL, Robert. Poliarchy, p. 5-8. Schmitter e Karl, em texto mais recente, ratificaram a concepção dahliana de democracia política, acrecentando-lhe mais dois requisitos: (i) "os funcionários eleitos devem ser capazes de exercer suas atribuições constitucionais sem estarem submetidos à oposição (ainda que informal) derrogatória dos funcionários não eleitos"; e (ii) "o governo deve ser autônomo; deve agir independentemente dos constrangimentos impostos por algum outro sistema político abragente". No original: "popularly elected officials must be able to exercie their constitutional powers without being subjected to overriding (albeit informal) opposition from unelected officials" e "the polity must be self-governing; it must be able to acto independently of constraints imposed by some other overarching political system". SCHMITTER, Philippe C.; KARL, Terry L. What democracy is ... and is not, p. 45.
} 
veto e de constrangimento típicos dos regimes autoritários. Há uma marcada necessidade de certo grau de consenso. Como visto, esse acordo é que permite a coordenação das ações políticas dos diferentes atores, regulando o acesso e o controle sobre os recursos de poder, o que permite uma concepção estratégica da ação dos grupos políticos na sociedade. Tratase de um pacto selado entre todos os contendores, reconhecendo expressamente um conjunto mínimo de regras e procedimentos capazes de pautar uma disputa relativamente pacífica no campo da política.

O conteúdo básico desse acordo passa pela tolerância às diferenças e ao pluralismo, garantindo as liberdades e preservando um espaço relevante para as concepções diversas no jogo da política. Daí o axioma de Dahl, que sintetiza a ideia de democracia recuperada por essa tradição: os custos da repressão, que consistem na supressão da oposição, seriam maiores do que admitir a coexistência ${ }^{276}$. É justamente a ruptura desse acordo fundamental que costuma dar causa ao autoritarismo.

Com pequenas alterações, encontram-se os mesmos critérios na obra de quase todos os cientistas políticos que se filiam à corrente dominante do pensamento democrático até nossos dias.

Para tomar um exemplo, Huntington, o pai da "teoria das ondas de democratização", considera que o conceito processual de democracia vence os demais na década de 70, por ser mais operacional, preciso e utilizável empiricamente. Nas suas palavras, o confronto entre "definições racionalistas, utópicas e idealistas de democracia" e as "definições empíricas, descritivas, institucionais e processuais" levam necessariamente à que somente a última definição permitia a precisão analítica e os referenciais empíricos que tornam utilizável o conceito"277.

Nesse sentido, esse autor desqualifica as diversas definições da democracia baseadas em teorias normativas, chegando a afirmar que são desprovidas de "bom-senso" e que viraram até mesmo um "oba-oba". A seu ver, a questão permanece sendo, como sempre foi, a centralidade dos mecanismos eleitorais, que permitem escolher os que governarão. Em suas palavras, "a eleição popular dos principais tomadores de decisões é a essência da democracia”, ou ainda que "eleições abertas, livres e imparciais são a essência da democracia, o inescapável sine qua non" 278 .

\footnotetext{
${ }^{276}$ WEFFORT, Francisco. Qual democracia?. São Paulo: Companhia das Letras, 1992. p. 95/96.

277 HUNTINGTON, Samuel p. A terceira onda, p. 16.

278 HUNTINGTON, Samuel p. A terceira onda, p. 18. Nessa mesma linha, a constatação de Whitehead, para quem "a definição consensual de democracia dos anos 1980 advogava uma definição minimalista ou procedimental. (...) A década de 1980 sinalizou um consenso prático e analítico na América Latina e, mais
} 
Os demais autores considerados também indicam, como elementos típicos de uma democracia política, atributos semelhantes. A cidadania, entendida como uma igualdade entre os membros da comunidade política, é um dos princípios orientadores de uma democracia $^{279}$. Além disso, o princípio da prevalência da vontade da maioria, a representação territorial, a soberania do poder legislativo, a eleição direta do poder executivo são outros aspectos relevantes ${ }^{280}$.

Em especial, ganha destaque um "mínimo procedural" composto por requisitos absolutamente indispensáveis nesse "consenso" sobre a ideia de democracia política, tais como "voto secreto, sufrágio universal, eleições regulares, competição interpartidária, reconhecimento das associações voluntárias e responsabilidade executiva dos governantes" ${ }^{281}$. Essa concepção procedimental ou procedural indaga, essencialmente, sobre até que ponto as regras de procedimento próprias do jogo democrático estão efetivamente instaladas em uma dada sociedade ${ }^{282}$.

Por seu turno, Przeworski, sem descartar a centralidade dessa dimensão processual e formal, joga luz na incerteza quanto aos resultados como requisito da democracia política, outra perspectiva para uma mesma visão. Em sua clássica definição, democracia "é um sistema de processamento de conflitos no qual os resultados dependem do que os participantes fazem, mas nenhum força isolada controla o que ocorre. Resultados de um conflito particular não são conhecidos ex ante por nenhuma das forças políticas concorrentes, porque as consequências de suas ações dependem das ações de outras (...). Assim, do ponto de vista de cada participante, os resultados são incertos" ${ }^{\text {283 }}$. Só que essa incerteza é organizada, o que faz da democracia um regime de uma abertura regulada

genericamente, que o regime democrático eleitoral envolve sufrágio universal". No original: "the consensual definition of democracy of the 1980s advocated a "minimal" or "procedural" definition. (...) The 1980s signaled a practical and an analytical consensus in Latin America, and more generally, that a democratic electoral regime involves universal suffrage". WHITEHEAD, Laurence. Latin America, p. 200.

279 O’DONNELL, Guillermo; SCHMITTER, Philippe C. Transições do regime autoritário, p. 24.

${ }^{280}$ O'DONNELL, Guillermo; SCHMITTER, Philippe C. Transições do regime autoritário, p. 25.

281 O’DONNELL, Guillermo; SCHMITTER, Philippe C. Transições do regime autoritário, p. 25.

${ }^{282}$ MOISÉS, José Álvaro. Entre a "incerteza" e a tradição política, p. 96. Costa critica esse conceito de democracia centrado unicamente na vigência de 'instituições' democráticas (eleições livres, direitos civis garantidos, normalidade da atividade parlamentar etc), o que "confina o estudo da democratização apenas à esfera institucional". COSTA, Sergio. Movimentos sociais, democratização e a construção de esferas públicas locais.

${ }^{283}$ No original: "is a system of processing conflicts in which outcomes depend on what participants do but no single force controls what occurs. Outcomes of a particular conflict are not known ex ante by any of the competing political forces, because the consequences of their actions depend on actions of others (...). Hence, from the point of view of each participant, outcomes are uncertain". PRZEWORSKI, Adam. Democracy and Market, p. 28. Mais adiante, apurando melhor sua conceituação, esclarece que os resultados dos processos democráticos não são incertos, mas assim parecem aos participantes. No original: "the outcomes of democracy process are not uncertain. They only appear to be uncertain to every participant” (p. 45). 
quando aos resultados ( "democracy is a system of ruled open-endedness, or organized uncertainty").

Em sua visão, essa incerteza é inerente à democracia e, sobretudo, a seus resultados, pois acomete a visão dos participantes e dá lugar à ação instrumental de cada um deles, motivando-os à mobilização em defesa de seus interesses. Não fosse assim, não haveria razão para esses atores organizarem-se e participarem da vida política ${ }^{284}$.

Nessa linha, esse autor postula que, para definir democratização, deve-se antes focalizar o aspecto da democracia enquanto forma de organização política. $\mathrm{O}$ ponto saliente e mais importante, sob esse ponto de vista, seria essa "incerteza referencial", de acordo com a qual ninguém pode ter a certeza de que seus interesses sairão vencedores a priori, pois prevalecem a competição e a incerteza ${ }^{285}$.

De forma bastante resumida e esquemática, esses são os traços gerais da ideia hegemônica de democracia política que permeia a análise dos transitólogos estudados, com pequenas variações de acento entre eles. É a partir dessa ideia minimalista e procedimental, centrada nas instituições que pautam os conflitos e as disputas, que avaliam os processos de democratização.

De acordo com essas premissas, é bastante ilustrativa a forma como Przeworski chega a definir a democratização. Trata-se de submeter todos os interesses à competição entre os jogadores, institucionalizando a incerteza quanto ao resultado das interações políticas. Ou seja, nesse ponto, fica clara a máxima que caracteriza a efetiva chegada a um regime democrático: quando o poder é devolvido de um grupo de pessoas para um aparato de regras capazes de orientar o jogo político ${ }^{286}$.

\footnotetext{
${ }^{284}$ No original: "if outcomes were either predetermined or completely indeterminate, there would be no reason for groups to organize as participants". PRZEWORSKI, Adam. Democracy and Market, p. 13.

${ }^{285}$ PRZEWORSKI, Adam. Amas a incerteza e serás democrático, p. 37.

${ }^{286}$ No original: "an act of subjecting all interests to competition, of institutionalizing incertainty. The decisive step toward democracy is the devolution of power from a group of people to a set of rules". PRZEWORSKI, Adam. Democracy and Market, p. 14. Em outro texto, afirma que a democratização pode ser entendida exatamente como o "simples ato de devolução do poder às instituições, o que permite e conduz a um inter-relacionamento incerto das forças políticas". PRZEWORSKI, Adam. Amas a incerteza e serás democrático, p. 46. A perspectiva institucionalista desse autor fica ainda mais evidente nesse outro trecho, no qual conclui que "o problema da democratização consiste em instituições. Recursos de forças políticas são dados; assim são suas preferências e condições independentes de todos. O jogo é resolvido se um sistema de instituições que engendra confiança espontânea for um equilíbrio da transição". No original: "Thus, the problem of democratization consist of institutions. Resources of political forces are given; so are their preferences and the conditions independent of everyone. The game is solved if a system of institutions that engenders spontaneous compliance is an equilibrium of the transition". PRZEWORSKI, Adam. Democracy and Market, p. 39. Segundo esse autor, três são as premissas desse raciocínio que aqui se qualifica como institucionalista: i) instituições importam; ii) há diferentes formas de organizar democracias e iii) instituições fazem diferença não apenas em eficiência, mas também possuem profundos efeitos distributivos (p. 26 e 27).
} 


\subsubsection{Críticas à concepção minimalista da democracia}

Diversas críticas foram apontadas a essa forma minimalista de compreensão da democracia, que privilegia uma autonomia institucional do campo político e, mais especificamente, sua dimensão procedimental. Democracia passa a ser vista, estritamente, enquanto configuração institucional materializada, sobretudo, nas características formais das disputas em torno dos postos de mando ${ }^{287}$.

As mais contundentes objeções, vale frisar, estiveram centradas em destacar a influência de traços mais estruturais e de fatores de longo prazo nas mudanças políticas e na afirmação das novas democracias. Em outras palavras, esses estudos posteriores buscaram relevar a multidimensionalidade do fenômeno, incorporando condicionantes e mediações que eram desconsiderados nas análises mais tradicionais dessa teoria das transições.

A maior parte dessas análises posteriores, inevitavelmente, esbarrava em uma constatação fundamental. O ponto de partida que tomavam era o fato de que, a despeito do fim dos regimes ditatoriais, era marcante ainda a persistência de práticas sociais e de uma cultura política autoritárias nesses países de transição recente ${ }^{288}$.

Essa constatação seria amplamente reconhecida entre os estudiosos desse tema pouco tempo após a edição das principais obras da transitologia, colocando seriamente em xeque a visão institucional e não normativa de democracia até então prevalente. Exemplo disso é a colocação do cientista político Paulo Sérgio Pinheiro, ao afirmar que "durante as transições democráticas na América Latina nos anos 80, havia a grande esperança de que o fim das ditaduras significasse a consolidação do Estado de Direito (...). No entanto, quando

\footnotetext{
287 Przeworski é contundente em defender que "as soluções para o problema de democratização residem nas instituições", pois "o que está em questão em qualquer processo de democratização são as garantias, e estas só podem ser institucionais". Esse autor exclui a possibilidade da democracia ser o resultado de um compromisso baseado exclusivamente em questões substantivas, pois as partes não se vinculam a obrigações como em um contrato e as visões substantivas de cada agente são sempre particulares. Nessa linha, "os acordos substantivos são possíveis apenas se garantidos institucionalmente”. PRZEWORSKI, Adam. Amas a incerteza e serás democrático, p. 38 e 41.

${ }^{288}$ Leonardo Avritzer formula com precisão esse paradoxo que a teoria da transição não consegue solucionar: "como seria possível que o autoritarismo constituísse apenas um veto à livre coordenação da ação política e que, ao mesmo tempo, características de uma ordem política autoritária permanecessem no sistema político mesmo após a retirada desse veto?". AVRITZER, Leonardo. Cultura política, atores sociais e democratização. Nesse mesmo sentido, Branco interpela essa tradição, pois é fato reconhecido que "para que houvesse mudança de um regime não-democrático para outro democrático seria preciso transformá-lo inteiramente, tanto quanto aos procedimentos, quanto aos seus valores, quanto à sua estrutura". Então, diante dessa constatação, "não parece ser uma tarefa por demais gigantesca para se processar em um curto período histórico e, ainda mais, indefinido quanto ao seu resultado?”. BRANCO, Marcello Simão. Da transição dos anos 80 para o início do século XXI, p. 24.
} 
as sociedades latino-americanas passaram por transições de ditaduras para governos civis, as práticas autoritárias de seus governos não foram afetadas por mudanças políticas ou eleições: sob a democracia prevalece um sistema autoritário, incrustado em especial nos aparelhos de Estado de controle da violência e do crime"289.

Nessa linha, um primeiro aspecto que foi bastante problematizado na literatura especializada refere-se à visão de que a democracia pudesse ser reduzida ao estabelecimento de regras e procedimentos capazes de garantir a alternância rotineira do poder entre os rivais eleitorais. O resto, nomeadamente as questões substanciais, deveria ser postergado para discussão e deliberação em um jogo político já normalizado e rotinizado, situação tão desejada quanto incerta ${ }^{290}$. Por exemplo, Vitullo questiona esse viés exclusivamente político-institucional da democracia, inquirindo a razão de não se incorporar a dimensão da democratização social e da justiça substantiva nessas análises ${ }^{291}$.

Não são só as questões econômicas e sociais que ficaram de fora dessas análises. Javier Santiso, outro profundo conhecedor dessa tradição, pontua a importância das crenças e valores na afirmação de um regime democrático. Afirmou que como a democracia não repousa somente sobre uma legitimidade legal ou procedimental, o regime democrático deve, igualmente, de maneira implícita, assentar sua legitimidade sobre os valores e as crenças ${ }^{292}$.

O próprio Guillermo O’Donnell, posteriormente, formulou uma (auto)crítica com esses mesmos fundamentos, que pode ser direcionada, de modo geral, para a visão adotada durante as primeiras reflexões dessa geração de transitólogos. Em outro momento histórico,

289 PINHEIRO, Paulo S. Introdução: os Estados de Direito e os Não-Privilegiados na América Latina. In: .; MENDEZ, Juan F.; O’DONNELL, Guillermo (Org.). Democracia, violência e injustiça: o NãoEstado de Direito na América Latina. São Paulo: Paz e Terra, 2000. p. 11. Daí esse autor sustentar, nesse mesmo texto, que a "democracia não é um regime político estático, mas um horizonte móvel. Sem que jamais o processo esteja concluído" (p. 28). Em instigante reconstituição das "microdimensões do poder" e dos "microdespotismos" que perpetuam o "autoritarismo socialmente implantado", mesmo no interior do regime democrático, esse autor afirma que "a violência ilegal do Estado e a impunidade da violência por parte dos cidadãos continua depois das transições políticas, mascarada pela retórica democrática, dissimulando relações fundamentais de força intocadas". PINHEIRO, Paulo Sérgio. Autoritarismo e transição, p. 45.

${ }^{290}$ Wanderley Guilherme dos Santos, já no prefácio de uma compilação de textos de sua autoria publicada em 1978, questionava contundentemente essa ideia que, em seguida, nos primeiros estudos da transitologia, ganharia grande fôlego. Ele afirmava o "equívoco de supor que a conversão do autoritarismo à democracia dependia estritamente de medidas jurídico-formais, independentes de discussões sobre questões de substância. Estas, aliás, deviam ser adiadas para o período pós-conversão, a fim de não dispersar esforços ou dividir as correntes anti-autoritárias". SANTOS, Wanderley Guilherme dos. Estratégias de descompressão política. In: . Poder \& Política: crônica do autoritarismo brasileiro. Rio de Janeiro: Forense Universitária, 1978 $\overline{[1973]}$. p. 15.

${ }^{291}$ VITULLO, Gabriel Eduardo. Além da transitologia e da consolidologia, p. 26.

292 No original: “comme la démocratie ne repose pas seulement sur une 'légitimaté légale' (Weber) ou 'procédurale' (Luhmann), le régime démocratique doit de manière implicite également asseoir sa légitimité sur des valeurs et des croyances". SANTISO, Javier. La démocratie incertaine, p. 987. 
saindo em defesa de uma concepção mais sofisticada e substancial de democracia, O’Donnell distanciou-se um pouco dessa "definição estritamente política, basicamente schumpeteriana" como aquela cujos defensores argumentariam sempre que, "embora as características do país $\mathrm{X}$ possam ser lamentáveis, esse país pertence sem dúvida ao conjunto das democracias. Essa é uma visão da democracia como regime político, independente das características do Estado e da sociedade"293.

Ele reconheceu, ainda, em um texto de 1988, para que se faça justiça à posição mais complexa que passou a adotar, que as democratizações latino-americanas não implicavam uma, mas duas transições. Admitindo tratar-se de um mesmo decurso histórico, O’Donnell passou a postular que a primeira transição "é a que vai do regime autoritário anterior até à instalação de um governo democrático. A segunda vai desde este governo até à consolidação da democracia ou, em outras palavras, ate à efetiva vigência de um regime democrático",294.

Isso porque, depois do período propriamente transicional, chegou a hora do desencanto com o resultado desses processos, muito distintos e aquém do que prometeram as previsões iniciais, marcadas por enorme dose de otimismo. Diante da constatação das desilusões com as mudanças políticas implementadas e das debilidades que as novas democracias anunciavam, esse autor reformulou o percurso padrão da transição, incorporando as dificuldades então enfrentadas para converter um regime pós-autoritário sui generis em uma autêntica democracia política.

Essa outra elaboração é interessante, por trazer novos elementos para se pensar os bloqueios e deficiências das democratizações latino-americanas. A primeira transição estaria concentrada mais na figura do Estado, com a instauração de um governo democrático a geri-lo, enquanto que a segunda, mais profunda, diz respeito à instauração de um regime efetivamente democrático, o que depende, predominantemente, da relação entre Estado e sociedade civil. Nessa direção, há uma nítida revisão dos postulados

293 O’DONNELL, Guillermo. Poliarquias e (In)efetividade da lei na América Latina: uma conclusão parcial. In: ___ _ MENDEZ, Juan F.; PINHEIRO, Paulo Sérgio (Org.). Democracia, violência e injustiça: o NãoEstado de Direito na América Latina. São Paulo: Paz e Terra, 2000. p. 338.

294 O’DONNELL, Guillermo. Transições, continuidades e alguns paradoxos, p. 43. Cumpre ressaltar que "a linha divisória entre essas duas transições não é sempre fácil de identificar precisamente". No original: "the dividing line between these two transitions is not always easy to identify precisely". MAINWARING, Scott; O’DONNELL, Guillermo; VALENZUELA, J. Samuel (Ed.). Issues in Democratic Consolidation: the New South American Democracies in Comparative Perspective. Introduction. Notre Dame: University of Notre Dame, 1992. p. 2. Essa ideia é retomada por Luciano Martins ao analisar o caso brasileiro, quando distingue regime de situação democrática. O autor afirma que "se há uma tensão entre o Estado de direito e o processo político é porque não há ainda um regime democrático, mas uma "situação democrática". MARTINS, Luciano. Ação política e governabilidade na transição brasileira, p. 262. 
anteriores de caráter mais deterministas quanto à sequência dos estágios das transições, pois se a primeira é mais fácil de ocorrer com a retirada dos vetos autoritários da política institucional, a segunda depende de diversos outros fatores e por isso tem um ritmo muito mais lento. ${ }^{295}$. Isso não significou, de modo algum, uma negação da autonomia da política que sempre foi tão cara ao pensamento desse autor, mas apenas a consideração de condicionantes de outras ordens que limitam e influenciam as escolhas dos atores estratégicos nos jogos de poder ${ }^{296}$.

Outros cientistas políticos, inicialmente engajados de cabeça na transitologia e seus pressupostos, revisitaram os textos mais antigos e também confessaram uma mea culpa, ainda que tímida e justificada pelas mudanças de contexto. Por exemplo, Whitehead, que participou do ambicioso projeto que impulsionou esse campo de pesquisas, afirma, em livro mais recente, que "a maioria dos analistas focou-se em uma visão mais precisa e talvez pouco estreita da democracia política, preocupada, sobretudo, com questões procedimentais. Esse enfoque necessariamente excluiu - ou ao menos empurrou para as margens - muitas preocupações que são centrais para a maior parte das discussões sobre a qualidade da democracia"297.

295 É importante esclarecer que esse conceito se refere estritamente à democratização ainda em seu âmbito essencialmente político. Adverte o próprio O’Donnell que "a democracia à qual me refiro é a democracia política (...), ela pode coexistir com diversos graus de democratização (e com sua falta) nos planos econômico, social e cultural. Por duas razões é importante deixar bem clara essa distinção: uma, porque considero a conquista da democracia política sumamente valiosa em si mesma; outra, porque a distinção entre, por um lado, a democracia política e, pelo outro, a democratização sócio-econômica e cultural, é precisamente o que nos permite explorar as relações e variações entre ambas". O’DONNELL, Guillermo. Transições, continuidades e alguns paradoxos, p. 43. Mais tarde, também esse seu entendimento será novamente reformulado. Exemplo bastante significativo dessa mudança de posicionamento é o conceito de “democracia delegativa" utilizado por O’Donnell para caracterizar o regime político surgido em alguns países latino-americanos após as transições. Segundo esse conceito, nessas democracias recentes marcadas por extremas desigualdades sociais e atitudes políticas autoritárias, a função de representação não chegou a se institucionalizar, ou chegou a fazê-lo apenas de modo deficitário. Isso levaria à ausência de mecanismos de controle sobre a ação dos governantes, acentuando a dimensão plebiscitária da escolha destes e ratificando as tendências personalistas. Esses elementos, aliados à fragmentação do sistema partidário e as tensões entre os Poderes do Estado, em um contexto de crise econômica, poderia levar a uma situação de ingovernabilidade. De algum modo, esse conceito veio em resposta às diversas críticas apontadas aos primeiros estudos da transitologia e, também, buscaram dar conta de uma realidade de vigência apenas formal da democracia.

${ }^{296}$ Cabe aqui mencionar o pertinente alerta de José Álvaro Moisés, para quem "é um equívoco contrapor-se a democratização social e econômica à democratização política; na realidade, a questão consiste menos em saber se a democracia social vem antes da política, e mais em definir "como", isto é, através de que regras político-institucionais a contestação mencionada antes pode ser "controlada", isto é, pode ser "regulada" pelas instituições políticas, de modo a não impedir que a luta pela igualdade social e econômica se realize como parte do sistema democrático ou, alternativamente, evitando que ela desande em violência política". MOISÉS, José Álvaro. Entre a “incerteza” e a tradição política, p. 98.

${ }^{297}$ No original: “(...) most analysts focused on a rather precise and perhaps somewhat narrow view of political democracy concerned above all with procedural issues. This focus necessarily excluded - or at least pushed to the margins - many concerns that are central to most discussions of the "quality of democracy"'. WHITEHEAD, Laurence. Latin America, p. 199. Esse autor vai além na autocrítica, ao escrever que "uma 
Nesse ponto, um segundo questionamento importante feito à literatura aqui pesquisada, já mencionado de passagem anterior, diz respeito ao viés elitista da política com que trabalham. Os modelos analíticos dessa tradição enfocam os embates e os acordos políticos travados apenas entre as elites, consideradas estas como atores estratégicos quase que exclusivos dos jogos de poder. Os outros jogadores ocasionalmente incorporados às análises aparecem de maneira bastante marginal e submissa. Essa perspectiva, é evidente, negligencia e subestima o peso da sociedade civil e, em especial, dos públicos democráticos nas decisões políticas, exagerando o grau de autonomia dos atores relevantes na escolha dos regimes políticos e a força das lideranças integradas às elites políticas ${ }^{298}$.

Outra insuficiência importante e cada vez mais percebida refere-se ao papel menor reservado à cultura política, tanto a que orienta as elites quanto a que informa os públicos de massa. Emergiram diversas interpretações integrando esse elemento analítico e obtendo resultados bastantes satisfatórios para a compreensão das democratizações latinoamericanas e seus percalços.

Ao contrário do olhar que privilegia apenas um viés político-institucional e eminentemente eleitoral, característico da transitologia, essa proposta explicativa fundamentada na cultura política é mais dinâmica e substancial, apresentando grande capacidade heurística para a compreensão da continuidade do autoritarismo na sociedade e no Estado pós-transicionais. Aqui reside o ponto forte da crítica proposta por José Álvaro Moisés, quando afirma claramente que "a diferença mais importante do presente estudo em relação aos anteriores consiste na ênfase que dou ao tema da cultura política, isto é, à dimensão relativas às tradições, atitudes e comportamentos políticos como parte fundamental da explicação dos processos de mudança de regimes políticos"299.

Sendo assim, para esse cientista político, não é possível ignorar as tradições políticas e os novos padrões político-culturais emergentes na América Latina, ainda que se

geração depois, nós podemos observar que os resultados dessa rota distinta para a democratização política estavam desconectados de uma associação direta com grande parte da tradicional agenda substancial de questões sociais". No original: "A generation later, we can observe the results of this distinctive route to political democratization, one disconnected from direct association with much of the region's traditional substantive social agenda" (p. 200).

${ }^{298}$ José Álvaro Moisés, para se ater apenas a um exemplo, cita duas convincentes contraprovas que atestam a influência da pressão dos públicos de massa no desenrolar dos processos transicionais. A primeira é o momento da Constituinte brasileira, com ampla participação popular no processo de elaboração do texto, que ampliou direitos e manteve privilégios corporativistas.A segunda é a transição espanhola, no período entre a morte de Franco e o plebiscito que aprovou as reformas políticas em 1977, ocasião em que Adolfo Suarez aproveitou a aprovação de quase $80 \%$ para avançar suas medidas de governo sem submeter a negociações com outros setores da elite política. MOISÉS, José Álvaro. Entre a "incerteza” e a tradição política, p. 92-93. ${ }^{299}$ MOISÉS, José Álvaro. Entre a "incerteza” e a tradição política, p. 89. 
considere os efeitos contingentes das transições. Nesse quadrante, fatores de médio e longo prazos, exógenos (estruturas) e endógenos (volitivos), enfim, todos desempenham papel importante nas motivações dos atores políticos para suas respectivas escolhas. Isso porque os atores políticos não decidem politicamente no vazio, mas em um contexto em que a ação é sempre mediada pela vida social e seus diversos fatores. Nos casos latinoamericanos, por exemplo, não se poderia subestimar a influência de legados tradicionais e arcaicos que constituem a experiência política dessas nações, tais como o patrimonialismo, o clientelismo, o elitismo etc.

Nessa mesma linha e incorporando outras ponderações críticas bastantes consistentes, é a análise de Leonardo Avritzer, que questiona a compreensão da democracia sem quaisquer adjetivos, apenas como ausência do autoritarismo. Essa formação empobreceria as possibilidades de convivência democrática e a universalidade dos direitos humanos, por desconsiderar uma experiência vivida não só com regras e procedimentos, mas com valores e crenças. Não se poderia, em nossos dias, ignorar ou subestimar essa dimensão substancial.

Para esse autor, que sistematiza bem os problemas da teoria da transição, dois pressupostos dessa tradição devem ser questionados. O primeiro é "a noção de que a ausência de constrangimento (veto) sobre o sistema político possa ser entendida como democratização" ${ }^{300}$, que acarreta uma incapacidade de compreensão da internalização ou não pelos atores políticos de uma normatividade democrática. Já o segundo pressuposto criticado é o de que "a democracia constitui um fenômeno relacionado exclusivamente com a operação das instituições e do sistema político" ${ }^{\text {301 }}$, o que implica um descaso das relações entre Estado e sociedade civil.

Além disso, esse cientista político coloca em questão três elementos constitutivos das teorias da transição. O primeiro é a ideia de que a democratização deve, necessariamente, decorrer de uma conexão entre o autoritarismo e a democracia, como se a ausência do primeiro levasse de modo mais ou menos natural à segunda. Outro aspecto criticado é o fato dessa tradição desvincular o autoritarismo dos problemas de constituição do Estado moderno, ou seja, desconsiderar a relação estreita entre formas modernas de racionalidade política e formas contemporâneas de autoritarismo. Por fim, uma última crítica é a de que as relações entre Estado e sociedade não devem ser concebidas apenas

\footnotetext{
${ }^{300}$ AVRITZER, Leonardo. Cultura política, atores sociais e democratização.

301 AVRITZER, Leonardo. Cultura política, atores sociais e democratização.
} 
enquanto continuidade, como faz crer essa literatura. Isso faz perder de vista as ações sociais de caráter coletivo e solidário, que têm impacto no sistema político ${ }^{302}$.

\subsubsection{Relações entre liberalização e democratização}

Dessa breve exposição, restam claras as diferenças existentes entre esses dois processos. Relativamente autônomos entre si, no esquema analítico considerado, de forma ideal, esses momentos apresentam-se encadeados de forma sequencial. Ou seja, após as medidas liberalizantes, para que não se estabilize um regime autoritário renovado e adaptado às pressões sociais oposicionistas, faz-se necessário colocar em marcha uma democratização efetiva.

Nessa escala evolutiva, orientada normativamente, há uma gradação do potencial real de transformação das medidas e de seu impacto no sistema político, desde as mais superficiais, que podem ser compatibilizadas com o autoritarismo, até as mais profundas e estruturais, de difícil conciliação com o status quo. De forma bastante resumida, enquanto as medidas liberalizantes logram, no máximo, uma série de mudanças no interior do regime, as democratizadoras, por sua vez, implicam uma verdadeira mudança do próprio regime.

Pode-se afirmar, desse modo, que enquanto a liberalização seria um sentido fraco para a transição, a democratização seria seu sentido forte, de acordo com a perspectiva normativa de busca da democracia, compartilhada na literatura analisada.

Nesse mesmo sentido, outra maneira de formular a relação entre ambos processos está expressada na síntese formulada por um notório representante dos estudos empíricos da transitologia, que restringe a liberalização a uma relação prioritária entre o Estado e a sociedade civil, enquanto que a democratização diria respeito, predominantemente, à relação entre o Estado e a sociedade política ${ }^{303}$.

\footnotetext{
${ }^{302}$ AVRITZER, Leonardo. Cultura política, atores sociais e democratização. À luz dessas ponderações, para esse autor, "a democratização consiste, portanto, na combinação entre a livre operação do sistema político e a compreensão do significado atribuído pelos atores políticos à democracia. Esse significado implicará diferentes concepções acerca da publicidade, da tolerância, da importância de estratégias de negociação e da importância da normatividade democrática". Ainda que não caiba aprofundar mais esse assunto nessa dissertação, é nítida a diferença existente entre essas concepções de democracia.

${ }^{303}$ STEPAN, Alfred (Org.). Democratizando o Brasil, p. 25.
} 
Por isso, a democratização aparece apenas como uma das diversas possibilidades abertas no horizonte de um regime em processo de liberalização. Mas também não é qualquer uma; é a mais desejada e adequada. Daí O’Donnell e Schmitter, no texto manifesto dessa tradição, fixarem expressamente o intervalo de interesse teórico para essa tradição pontuando como "terminus ad quo (...) o momento em que os dirigentes autoritários (ou, com mais frequência, alguma parcela deles) anunciam - e são acreditados - sua intenção de ampliar de forma significativa a esfera de direitos individuais e grupais protegidos", que seria justamente o momento da liberalização. No outro polo, ao final, insere a democracia política como "o terminus ad quem preferido do nosso esforço interpretativo, mas obviamente não constitui o final das lutas com relação à forma e o propósito da política"304. Aqui, também, fica patente a posição normativa ocupada pela democracia no final do processo transicional.

Para esses autores, que adotam essa visão sequencial, gradual e normativa da transição rumo a uma democracia política minimalista, cujas características principais já foram discutidas, a liberalização seria apenas um ponto de passagem prévio (e complementar) à democratização ${ }^{305}$. Por se tratar de etapas de uma mesma transição, apresentam uma lógica interna e se retroalimentam, apesar da relativa autonomia de que são dotadas.

Daí decorre a consideração, amplamente difundida, de que, iniciada uma transição, “conforme avança a liberalização, avança também a força das reivindicações de democratização"306. Nessa ótica, valendo-se de uma metáfora, a transição seria uma única peça teatral dividida em dois atos ou, precisando melhor a diferença entre ambos, um ensaio inicial e uma autêntica estreia. Qualitativamente distintos entre si, as duas fases são necessárias para o êxito do espetáculo.

No entanto, deve-se observar que a relação entre a liberalização e a democratização pode ser - e assim se mostrou concretamente nas transições latinoamericanas - muito mais complexa do que uma mera sucessão linear e pacífica entre momentos de uma evolução predeterminada.

\footnotetext{
304 O’DONNELL, Guillermo; SCHMITTER, Philippe C. Transições do regime autoritário, p. 29/30.

305 “Outra característica definitória desses trabalhos é a concepção sequencial ou gradualista que assumem. Há presente neles uma forma persistente de interpretar a realidade que pressupõe a existência de etapas ou estágios diferentes que irão abrindo o caminho para uma paulatina resolução dos problemas e déficits que sofre todo processo de democratização". VITULLO, Gabriel Eduardo. Transitologia, consolidologia e democracia na América Latina, p. 54-55.

306 O’DONNELL, Guillermo; SCHMITTER, Philippe C. Transições do regime autoritário, p. 28.
} 
Isso porque o sucesso de um projeto de liberalização, na maior parte das vezes concebido por forças políticas do próprio regime autoritário, implicou um persistente bloqueio para o aprofundamento da democratização, provocando uma acomodação dos atores estratégicos na estrutura do Estado, enfraquecendo a força oposicionista e, assim, mitigando os conflitos centrais para a radicalização da democracia.

Sob essa perspectiva, que prestigia a ambiguidade, a lógica de simples complementariedade entre liberalização e democratização termina suplantada por uma lógica de contradição e, no limite, até mesmo de exclusão entre esses dois processos. A partir desse outro ponto de vista, pode-se reconhecer a formação de certas figuras híbridas, admitidas por essa própria tradição, ainda que apenas de passagem e na condição de exceção à regra de uma sequencialidade entre esses dois momentos.

Nesse sentido, O’Donnell formulará dois conceitos para tratar de casos que escapam à norma, por quebrarem a expectativa de evolução padrão segundo a qual, após a liberalização, vem a democratização. O primeiro é o de "dictablanda", traduzido como "ditabranda" 307 para referir-se aos casos de autoritarismo liberalizado, ou seja, liberalização sem democratização, uma espécie de estancamento do processo no meio do caminho. O segundo é o de "democradura", para designar casos de democracia limitada ou de democratização sem liberalização, ou seja, no qual há aparência de democracia sem liberdades e garantias básicas ${ }^{308}$.

Assim, pelo caráter ideal-típico que a liberalização e a democratização assumem, não se verificam presentes, como tais, na própria realidade. Representam um esforço teórico de qualificar melhor e distinguir as medidas de abertura e afrouxamento de um regime autoritário. A articulação entre ambas obedece a uma regra geral de sucessão e retroalimentação, mas pode haver o desencontro e até mesmo uma contradição, como foi visto.

Assumida, no entanto, a formatação básica desse esquema analítico, resta questionar o que sucede, então, a fase da democratização? Com efeito, consumada uma

\footnotetext{
${ }^{307}$ Esse conceito teve grande repercussão no Brasil em virtude de um infeliz editorial veiculado pelo jornal Folha de São Paulo no dia 17 de fevereiro de 2009, usando-o de maneira inadequada para caracterizar a ditadura brasileira. Na verdade, segundo O'Donnell, pai dessa expressão, uma ditadura liberalizada, do tipo dictablanda pactada, consiste no controle estatal centralizado sobre atos de força arbitrários e violentos cometidos pelas forças armadas, evitando atos de vingança contra as mesmas e estabelecendo canais seguros para articulação de interesses e a discussão de alternativas de política pública. O'DONNELL, Guillermo; SCHMITTER, Philippe C. Transições do regime autoritário, p. 72. Isso, certamente, não ocorreu durante todo o período do regime autoritário brasileiro, como fez crer o referido editorial ao argumentar que a ditadura brasileira foi mais branda e menos violenta do que suas congêneres no Cone Sul.

${ }^{308}$ O’DONNELL, Guillermo; SCHMITTER, Philippe C. Transições do regime autoritário, p. 27.
} 
transição em conformidade com esse padrão, o que ocorre? Para responder a esse questionamento, é necessário examinar o conceito de consolidação democrática, tão caro a essa tradição.

\subsection{A consolidação democrática}

Nesse tópico, serão abordados os traços gerais da compreensão dessa geração de cientistas políticos quanto à ideia de consolidação democrática e a necessidade de normalização metodológica que ela implica nas reflexões teóricas. Em sequência, será então possível examinar as configurações da justiça nesse tipo de contexto e de método distinto da transição política.

\subsubsection{Quando a transição chega ao fim}

Durante as primeiras reflexões desses cientistas políticos, que escreveram no calor das mudanças políticas então em curso na América Latina e na Europa do Sul, por razões evidentes, o objeto central de preocupação eram as transições, sua dinâmica excepcional e sua imprevisibilidade. Como visto até aqui, diversas questões em torno dessa temática foram tratadas e bem desenvolvidas, o que permitiu a afirmação de um novo campo e de uma agenda de pesquisas específica no interior da ciência política, nomeadamente, a subdisciplina chamada transitologia.

Mas, desencadeado um processo de transição política, quais são seus desfechos possíveis? Basicamente e de modo bastante esquematizado, ressaltando a indeterminação dos pontos de chegada dessas mudanças, esses autores admitem que, pelos padrões medianos, há duas principais alternativas. A primeira é o empoderamento de um governo democrático (seja fundado em um pacto com as forças do antigo regime ou por uma ruptura com este); a segunda possibilidade, sempre a ser evitada, é a regressão a formas 
políticas autoritárias, que pode se materializar de diversas maneiras. Obviamente, há sempre graus intermediários, que desembocam em regimes mistos ${ }^{309}$.

Até o momento, nenhuma novidade nesse aspecto. No entanto, na medida em que os processos de transição foram-se consumando, mediante a relativa estabilização dos regimes políticos, materializada em novas regras e instituições, outras questões começaram a aparecer no horizonte desses cientistas políticos. Em particular, emergiu a discussão relativa à consolidação dessas democracias recém-nascidas.

Basicamente, porque constatavam grandes deficiências nos regimes recéminstalados, sobretudo nos países do Cone Sul. Mesmo depois de efetivada uma transição, mediante a formalização de procedimentos democráticos, esses cientistas políticos perceberam que restavam, ainda, muitos aspectos a serem cuidados, outras tantas condições que precisavam ser estabilizadas e, principalmente, faltava aos agentes do sistema político um aprendizado de atitudes e hábitos que deveriam ser cultivados ${ }^{310}$. Sem vencer esses desafios, uma democracia não poderia ser considerada, em definitivo, como consolidada.

É verdade que a temática da consolidação democrática já estava anunciada, nos estudos pioneiros de transitologia, como o grande objetivo último desses processos políticos. Isso porque a política, sob o signo do processo de democratização, era vista em dois tempos: a transição e a consolidação. Também já estava nítido que a oposição entre essas duas fases - respectivamente, o processo e o produto - era estruturante nessas primeiras reflexões.

Cada vez mais, foi ficando claro que a transição apenas lançava a possibilidade de que se chegasse a uma efetiva democratização; a questão era então saber quais as condições e decisões que levariam a esse caminho ideal.

No entanto, deve-se reconhecer que foi somente após o início da vida democrática nesses países, com o surgimento de novos problemas e dilemas, que assumiu destaque a

\footnotetext{
${ }^{309}$ Nessa tipologia, pode haver inclusive bloqueios que perpetuem indefinidamente as transições sem que elas cheguem a um desfecho identificável. Daí a estranha afirmação de uma transição que não leva, durante um período, a lugar algum: "pode haver transições que comecem sem jamais chegarem a termo, mesmo que um novo regime autoritário não venha a assumir o poder". LINZ, Juan; STEPAN, Alfred. A transição $e$ consolidação da democracia: a experiência do Sul da Europa e da América do Sul. São Paulo: Paz e Terra, 1999. p. 31.

${ }^{310} \mathrm{Na}$ feliz síntese de Moisés e Sadek, "uma vez concluída a passagem para a democracia, a questão fundamental, do ponto de vista operacional, diz respeito às condições institucionais de sua consolidação". Por isso esses autores propõem que se observe dois aspectos distintos da engenharia institucional: de um lado, a representação política e, de outro, as condições de governabilidade, ambos com base nos sistemas eleitorais e partidários. MOISÉS, José Álvaro; SADEK, Maria Tereza A. Perspectivas de consolidação democrática na América Latina. São Paulo em Perspetiva, São Paulo, v. 9, n. 1, p. 169-177, 1995. p. 169-177.
} 
seguinte indagação: quando se pode considerar que a transição foi consumada e, mais, que a democracia resultante da mudança foi consolidada?

Novamente, as respostas desses autores variaram pouco entre si, mantendo uma unidade capaz de caracterizá-los enquanto uma tradição. Linz e Stepan, que mais se debruçam sobre essa questão específica, traçam um padrão de definição mais operacional para permitir o estudo comparado dos diferentes processos de democratização, materializado em quesitos mais concretos. Dessa forma, uma transição democrática está completa quando um grau suficiente de acordo foi alcançado quanto aos procedimentos políticos visando obter um governo eleito; quando um governo chega ao poder como resultado direto do voto popular livre; quando esse governo tem, de fato a autoridade de gerar novas políticas; e quando os Poderes Executivo, Legislativo e Judiciário, criados pela nova democracia, não têm que, de jure, dividir o poder com outros organismos ${ }^{311}$.

Nessa mesma linha, no que se refere à consolidação, esses autores propugnam uma definição mais estreita de consolidação democrática, que, entretanto, combina "dimensões comportamentais, atitudinais e constitucionais". Em essência, "democracia consolidada [é] uma situação política onde, numa frase, a democracia passou a ser 'o único jogo disponível na sociedade"”. Dessa premissa, extraem os seguintes traços: nenhum grupo político de peso faz tentativas sérias de derrubar o regime democrático ou propor a secessão do Estado; a esmagadora maioria da população continua acreditando que qualquer mudança política adicional deva emergir do bojo dos parâmetros das fórmulas democráticas e todos os atores da comunidade política habituam-se ao fato de que todos os conflitos políticos serão resolvidos de acordo com as normas estabelecidas ${ }^{312}$.

Mas não basta uma interdição que define, negativamente, que uma democracia consolidada é um regime que inibe outras formas de solução dos conflitos. Nesse sentido, esses autores buscam um modelo analítico mais propositivo, estabelecendo cinco campos de interação que são necessários para o real funcionamento de uma democracia consolidada. Partem da premissa de que eleições e mercados não são critérios suficientes. De acordo com essa avaliação, a definição minimalista comum dessa tradição é então desdobrada em cinco tópicos, que dialogam com institucionalizações em diferentes

${ }^{311}$ LINZ, Juan; STEPAN, Alfred. A transição e consolidação da democracia, p. 21. De modo geral, para essa tradição, a transição democrática se completa com as primeiras eleições realizadas, marcando o fim da ditadura. Como explica Branco, "marco principal [são] as primeiras eleições gerais para o cargo político mais importante do país. As eleições representam a volta da normalidade institucional e o funcionamento prático de um regime democrático". BRANCO, Marcello Simão. Da transição dos anos 80 para o início do século $X X I$, p. 28.

${ }_{312}$ LINZ, Juan; STEPAN, Alfred. A transição e consolidação da democracia, p. 23. 
dimensões da vida social: sociedade civil, sociedade política, estado de direito, burocracia estatal e sociedade econômica institucionalizada.

Nas palavras desses autores, "primeiramente, deve haver condições para o desenvolvimento de uma sociedade civil livre e ativa. Em segundo lugar, deve haver uma sociedade política relativamente autônoma e valorizada. Terceiro, deve haver o estado de direito para assegurar as garantias legais relativas às liberdades dos cidadãos e à vida associativa independente. Quarto, deve existir uma burocracia estatal que possa ser utilizada pelo novo governo democrático. E, por último, deve haver uma sociedade econômica institucionalizada. Nenhum dos campos, por si só, num tal sistema, pode funcionar adequadamente sem algum apoio de outro, ou, na maior parte dos casos, de todos os outros campos"313.

E eles arrematam ressaltando a exigência de uma internalização normativa, fundamental para a rotinização, a fim de consolidar uma democracia: "em suma, com a consolidação, a democracia se torna rotina, além de profundamente internalizada na vida social, institucional e até mesmo psicológica, bem como nos cálculos visando atingir o sucesso"314.

Por sua vez, coerente com o papel marcante que a incerteza desempenha no sua reflexão sobre a democracia, Przeworski considera que a democratização foi consolidada quando a incerteza é, finalmente, institucionalizada. Duas são as categorias chaves de sua reflexão: a institucionalização e a incerteza. Ou seja, esse cientista político trabalha com a exigência de que, em uma democracia, ninguém possa controlar os resultados do processo político ex post, os resultados não são predeterminados ex ante e fazem a diferença dentro de certos limites previsíveis.

Somado a isso aparece outro critério, que Linz e Stepan também mencionam, mas que encontra sua melhor formulação em Przeworski. Trata-se da ideia de democracia tornar-se o único jogo disponível ("the only game in town"), ou seja, todos os jogares agem dentro das regras, legimitimando-as. Isso faz com que a democracia consolidada seja

\footnotetext{
${ }^{313}$ LINZ, Juan; STEPAN, Alfred. A transição e consolidação da democracia, p. 25 e 26.

${ }^{314}$ LINZ, Juan; STEPAN, Alfred. A transição e consolidação da democracia, p. 24. Ainda que não caiba desenvolver melhor, essa definição parece desconsiderar um problema bastante recorrente em diversos países: uma democracia consolidada, mesmo contando com o apoio e o consenso dos atores politicamente relevantes, pode sofrer uma ação desagregadora por parte de grupos políticos, ainda que minoritários e marginais, que afete a estabilidade e coloque em questão a ordem democrática. A conformidade dos comportamentos sociais às regras, de maneira abstrata, não é critério suficiente para definir uma estabilização, dado que o descumprimento de normas é recorrente em qualquer ordem constitucional democrática bem estabilizada. O problema é definir quem são os atores relevantes considerados para examinar se as normas são ou não efetivas, emergindo aí uma questionável arbitrariedade na análise.
} 
autoaplicável ("self-enforcing”), pois há consenso entre as forças políticas mais relevantes em sujeitar seus respectivos interesses e valores à interação incerta das instituições ("uncertain interplay of the institutions") 315 .

Em termos mais concretos, essa exigência se materializa nas seguintes características, palpáveis na dinâmica de funcionamento de um regime político: 1) efetivo controle civil sobre os militares; 2) possibilidade real de alternância partidária no poder; 3 ) essa alternância pode produzir mudanças políticas reversíveis ${ }^{316}$.

Ele ainda agrega um requisito bastante peculiar e complicado para que um regime seja qualificado como uma democracia consolidada. Mais do que a mera retirada do exército para os quartéis ou a abertura de um Parlamento eleito, é preciso que seja erigida uma interdição fundamental, segundo a qual nenhum ator poderá reverter as consequências do processo democrático formal. Trata-se de um tipo de impedimento decorrente da ideia da democracia como "único jogo possível", o que leva todos os jogadores, se aderiram às regras, a concordarem com seus resultados, ainda que desfavoráveis ${ }^{317}$. De modo mais sintético, nas palavras desse autor, "em qualquer processo de democratização bemsucedido há um momento em que o retorno não é mais possível"318.

\footnotetext{
315 Vale transcrever o trecho integralmente: “A democracia está consolidada quando, sob condições políticas e econômicas determinadas, um sistema particular de instituições torna-se o único jogo possível, quando ninguém pode se imaginar agindo por fora das instituições democráticas, quando tudo que os perdedores querem fazer é competir novamente pelas mesmas instituições sob as quais eles acabaram de perder. A democracia está consolidada quando ela é auto-aplicável, ou seja, quando todas as forças políticas relevantes acham que é melhor continuar a submeter seus interesses e valores à interação incerta das instituições. No original: "Democracy is consolidated when under given political and economic conditions a particular system of institutions becomes the only game in town, when no one can imagine acting outside the democratic institutions, when all the losers want to do is to try again within the same institutions under which they have just lost. Democracy is consolidated when it becomes self enforcing, that is, when all the relevant political forces find it is best to continue to submit their interests and values to the uncertain interplay of the institutions". PRZEWORSKI, Adam. Democracy and Market, p. 26 e 51.

${ }^{316}$ PRZEWORSKI, Adam. Como e onde se bloqueiam as transições para a democracia?, p. 21. Afirma, ainda, que será uma transição para a democracia se duas condições forem observadas: 1) o velho aparato de poder autoritário é desmantelado; 2) as novas forças políticas elegem as instituições democráticas como estruturas dentro das quais irão competir para a realização de seus interesses (p. 38).

${ }^{317}$ Escreve que "o momento crucial em qualquer transição do autoritarismo à democracia não é necessariamente a retirada do exército para os quartéis ou a abertura do Parlamento eleito, mas a transposição de um limiar para além do qual ninguém pode reverter as consequências do processo democrático formal. PRZEWORSKI, Adam. Como e onde se bloqueiam as transições para a democracia?, p. 37.

318 PRZEWORSKI, Adam. Como e onde se bloqueiam as transições para a democracia?, p. 38. Essa exigência é bastante problemática por razões evidentes. Nenhum regime político está imune aos riscos de rupturas em seu processo normal de funcionamento. Nem poderá reduzir esses riscos a zero, por maior que seja seu grau de institucionalização e estabilidade. Trata-se de certa ilusão, bastante idealizada, de que uma democracia consolidada não tenha possibilidade de retrocessos. Além disso, nenhum regime pode perdurar indefinidamente, ainda que essa seja a pretensão da maior parte deles. Para um aprofundamento dessa crítica, ver BRANCO, Marcello Simão. Da transição dos anos 80 para o início do século XXI, p. 39.
} 
Por sua vez, Valenzuela sustenta que o processo de consolidação democrática consiste na "eliminação de instituições, procedimentos e expectativas que são incompatíveis com o funcionamento mínimo de um regime democrático"319.

Como se nota, nessa literatura, há rol de tarefas e uma lista de exigências para que uma democracia seja adjetivada como consolidada. Alinhando-se aos postulados de uma democracia minimalista e procedural, vista apenas como um conjunto de regras e instituições para a solução dos conflitos, com destaque para os de viés eleitoral, esses autores defendem que uma transição se consuma quando a democracia se torna o único jogo possível e irreversível, aceito por todos os atores relevantes.

Não por acaso, todos os principais elementos apontados por esses autores, que a título de exemplificação foram mencionados acima, revelam os pressupostos normativos da reflexão feita pelos mesmos ${ }^{320}$. A consolidação democrática é diretamente associada, nessa tradição, ao grau de institucionalização ${ }^{321}$ do regime político considerado. Sob essa ótica, haveria uma espécie de linha evolutiva orientada, unicamente, pelo nível de estabilidade dos regimes políticos, prestigiando, portanto, uma dimensão funcional na análise.

Uma crítica consistente e que põe em questão toda essa conceituação de consolidação é a tendência, de acordo com essa interpretação corrente, de um congelamento das regras. Isso pode levar a uma supressão da incerteza típica da democracia, tornando-a infensa a mudanças e, portanto, conservadora. Vale citar Guilhot e

\footnotetext{
${ }^{319}$ No original: "eliminating the institutions, procedures, and expectations that are incompatible with the minimal workings of a democratica regime". VALENZUELA, Samuel J. Democratic consolidation in posttransitional settings: notion, process, and facilitating conditions. In: MAINWARING, Scott; O’DONNELL, Guillermo; _. Samuel (Ed.). Issues in Democratic Consolidation: the New South American Democracies in Comparative Perspective. Notre Dame: University of Notre Dame, 1992. p. 70.

${ }^{320}$ Ainda que pareçam neutras, as definições envolvem geralmente pressupostos normativos a partir dos quais um regime pode ser considerado democrático. Essa normatividade, orientada por uma idealização da democracia consolidada, com todas as características já vistas, será objeto de duras críticas. Alguns estudiosos consideram haver um excessivo idealismo que acaba levando a uma compreensão de todos os regimes políticos reais como versões imperfeitas e incompletas da democracia consolidada. Essa crítica aponta o caráter teleológico do conceito de consolidação democrática, que induz a uma análise da realidade de um ponto de vista imaginário, inatingível e ahistórico, sem levar em conta a concretude dos processos de mudança política. Essa crítica está bem formulada em GUILHOT, Nicolas; SCMITTER, Philippe C. De la transition à la consolidation, p. 626 .

${ }^{321}$ A institucionalização é considerada, nessa tradição, associada às ideias de consenso social e expectativa de permanência de um regime. Na definição de um desses autores, "institucionalização é o processo através do qual as organizações e os processos adquirem valor e estabilidade. O nível de institucionalização pode ser definido pela adaptabilidade, complexidade, autonomia e coesão de suas organizações e procedimentos". HUNTINGTON, Samuel P. A ordem política nas sociedades em mudança. Rio de Janeiro: Forense Universitária; São Paulo: EDUSP, 1975. p. 24. Não há dúvidas de que a institucionalização é compreendida, por esses autores, como eminentemente eleitorais, relativa, portanto, às regras do jogo eleitoral. Outros teóricos destacam a importância de atentar-se para a democratização de outros regimes parciais, como o regime capital-trabalho, regime civil-militar, regime de competências territoriais, enfim, estendendo o accountabilty a diversos setores da vida social. Cf. GUILHOT, Nicolas; SCMITTER, Philippe C. De la transition à la consolidation, p. 626 e 627.
} 
Schmitter, em texto posterior já mencionado, quando afirmam que "os teóricos da consolidação interpretaram as pressões em favor de mudanças posteriores como fatores de desconsolidação. Isso se deveu, principalmente, ao fato de que o conceito de consolidação, tal qual utilizada por eles, é intrinsecamente inadequado quando falamos de democracia",322.

Daí esses dois autores proporem outro conceito de consolidação, baseado em uma definição mais ampla da democracia, incluindo as relações entre governantes e governados que são geralmente ignoradas nessas reflexões, especialmente um controle civil sobre as forças armadas e a criação de um sistema de negociação coletiva entre os interlocutores sociais $^{323}$.

Contudo, apesar dessas críticas que possam ser endereçadas à consolidologia, o importante a registrar, para os fins deste trabalho, é que há uma série de diferenças fundamentais entre a transição e a consolidação democrática que vale explorar mais detidamente.

\subsection{A normalização metodológica}

Nessa tradição, a transição e a consolidação são duas dimensões complementares e sucessivas do processo de democratização, marcadamente autônomas e irredutíveis entre si. Aliás, esses processos seriam, por natureza, identificáveis apenas pela oposição entre ambos, pois onde termina um, pode começar o outro.

Nessa linha, a excepcionalidade característica dos momentos transicionais só existiria enquanto tal a partir do confronto com a normalidade de uma democracia em funcionamento regular. Em outros termos, e daí já se infere uma conclusão fundamental nesses marcos teóricos, enquanto a transição está centrada na ideia de um momento de exceção política, caracterizado pela intensa transformação das estruturas, a democracia se caracteriza como a vigência normalizada das regras e procedimentos que orientam os jogos de poder.

\footnotetext{
${ }^{322}$ No original: "les théoriciens de la consolidation à interpreter les pressions en faveur de changements ultérieurs comme des facteurs de déconsolidation. Cela est principalement dû au fait que le concept de consolidation, tel qu'il a été utilisé, est intrinsèquement inadéquat lorsqu'on parle de démocratie" GUILHOT, Nicolas; SCMITTER, Philippe C. De la transition à la consolidation, p. 623.

${ }^{323}$ No original: "L'analyse de la consolidation des régimes démocratiques doit donc élargir la définition restreinte de la démocratie qui était celle de la 'transitologie' et y inclure des aspects des relations entre les gouvernantes et les gouvernés qui sont généralement ignorés ou tunes pour acquis, tels que, entre autres, l'établissement d'un controle civil sur l'armée et la création d'un systéme de négociations collectives entre les partenaires sociaux". GUILHOT, Nicolas; SCMITTER, Philippe C. De la transition à la consolidation, p. 628.
} 
Sobre esse aspecto, vale recuperar a expressiva colocação de O’Donnell e Schmitter, para quem:

\begin{abstract}
a transição se encerra quando a 'anormalidade' já não constitui a característica principal da vida política; acontece quando os atores estabelecem - e respeitam um conjunto de normas mais ou menos explícitas que definem os canais a serem utilizados para acesso a cargos de governo, os meios que podem empregar legitimamente em seus conflitos os procedimentos a se aplicar na tomada de decisões estatais, e os critérios usados para excluir do jogo. Em outras palavras, a normalidade torna-se uma característica principal da vida política quando aqueles que estão ativos na política nutrem a expectativa de que todos ajam de acordo com as regras - e ao conjunto dessas regras de jogo denominado regime $^{324}$.
\end{abstract}

Esse argumento é de importância ímpar para compreender como se distinguem esses dois processos, com implicações metodológicas não menos importantes. Pois enquanto a transitologia é uma "teoria da mudança", preocupada com a natureza dos regimes (se democráticos ou não), a consolidologia é uma "teoria da ordem", cuja questão principal consiste em saber onde o governo realmente governa e onde não consegue fazê$10^{325}$.

Como decorrência dessa constatação, pode-se argumentar que o estudo da consolidação democrática, segunda fase das transições políticas, demarca uma verdadeira ruptura epistemológica em relação aos métodos da transitologia. Nas palavras do Guilhot e Schmitter, em trecho que vale ser transcrito: "a transformação das novas configurações políticas 'em rotina', ou seja, a consolidação, não implica somente atores, ritmos e processos diferentes (...), mas também uma outra concepção dos processos sociais e, para dizer de modo mais esquemático, um tipo de explicação baseada em uma forma de causalidade muito diferente. Essa 'ruptura' epistemológica manteve-se relativamente desapercebida, ainda que demande passar pelo crivo de uma análise crítica"326.

Assim, todos os conceitos e o esquema analítico elaborados para os momentos transicionais perdem sua capacidade heurística nas consolidações democráticas. Nestas,

324 O’DONNELL, Guillermo; SCHMITTER, Philippe C. Transições do regime autoritário, p. 107.

${ }^{325}$ Por isso a afirmação de que "la transition et la consolidations s'opposent l'une à l'autre comme, respectivement, une théorie du changement et une théorie de l'ordre". GUILHOT, Nicolas; SCMITTER, Philippe C. De la transition à la consolidation, p. 620 e 624. Ou ainda, nesse mesmo texto, a ideia de que "o objeto da consolidologia não é mais a mudança da natureza dos regimes políticos, mas o grau de institucionalização das regras que os definem". No original: "l'objet de la 'consolidologie' n'est plus le changement de la nature des régimes politiques, mais le degré d'institutionnalisation des règles les définissant" (p. 619).

${ }^{326}$ No original: 'La transformation des nouvelles configurations politiques 'en routine', c'est à dire la consolidalation, n'implique pas seulement des acteurs, des rythmes et des processus différent ..., mais aussi une tout autre conception des processos sociaux et, pour dire de façon un peu schématique, un type d'explication reposant sur une forme de causalité trés diferente. Cette 'rupture' épistemologique est restée relativement inaperçue bien qu'elle demande à être passée au crible d'une analyse critique". GUILHOT, Nicolas; SCMITTER, Philippe C. De la transition à la consolidation, p. 615. 
não vigora mais a suspensão dos condicionantes estruturais e das regras; tampouco os atores políticos têm poderes extraordinários na determinação dos rumos da vida social. Em suma, nas democracias consolidadas, reinstalada a normalidade, os processos políticos não mais se reduzem a meras contingências das estratégias dos jogadores e seus cálculos racionais $^{327}$.

O caminho da análise não é mais, unilateralmente, dos atores para as normas. Nessa nova dinâmica, típica de uma democracia consolidada, os resultados não dependem apenas de uma interação entre atores, sejam eles elites ou públicos de massa, mas passam novamente a variar conforme o relacionamento, de influência recíproca, que estes mantêm junto às regras e instituições já estabilizadas. Retoma-se, assim, a força de determinação e a capacidade explicativa das estruturas, fazendo com que os comportamentos sejam menos influentes e mais limitados. Portanto, mais previsíveis. O que então eram consideradas escolhas estratégicas de excepcional potência criadora convertem-se em comportamentos tidos como naturalmente apropriados ${ }^{328}$.

Essa tabela sobre os esquemas explicativos da transição e da consolidação é bastante esclarecedora dessas diferenças básicas:

Tabela 3 - Tabela comparativa entre transição e consolidação ${ }^{329}$

\begin{tabular}{|c||c|c|}
\hline & Transição & Consolidação \\
\hline \hline Variável independente & Escolhas & Regras \\
\hline \hline Variável dependente & Regras & Comportamentos \\
\hline Atores envolvidos & Elite restrita & $\begin{array}{c}\text { Elite ampla (partidos políticos, } \\
\text { intermediários etc.) ou conjunto de } \\
\text { cidadãos. }\end{array}$ \\
\hline
\end{tabular}

No entanto, deve-se frisar, essa reorientação do método e do esquema analítico não passa de uma "normalização metodológica" da própria transitologia, já que esta

\footnotetext{
327 Ainda que as escolhas sejam presentes durante as democracias consolidadas também, nas transições, tomam dimensões dramaticamente diferentes. Nesse sentido é a ponderação de MAINWARING, Scott. Transitions to democracy and the democratic consolidation: theoretical and comparative issues. In:

O'DONNELL, Guillermo; VALENZUELA, J. Samuel (Ed.). Issues in Democratic Consolidation: the New South American Democracies in Comparative Perspective. Notre Dame: University of Notre Dame, 1992. p. 329-331.

${ }^{328}$ Para uma discussão mais aprofundada desse esquema circular de interação recíproca em que os homens fazem as instituições e estas conformam os homens, ver GUILHOT, Nicolas; SCMITTER, Philippe C. De la transition à la consolidation, p. 621 .

${ }^{329}$ Adaptado de GUILHOT, Nicolas; SCMITTER, Philippe C. De la transition à la consolidation, p. 622.
} 
reconhece sua condição de teoria de situações excepcionais, marcadas por uma sorte de anormalidade. Ultrapassadas as transições, no estudo das consolidações, retoma-se, portanto, uma sociologia política mais clássica ${ }^{330}$, que restitui às estruturas e às demais condicionantes seu estatuto próprio.

Não são menores as implicações dessa mudança para a compreensão da justiça, que é o ponto a ser discutido a seguir.

\subsection{Justiça de consolidação? Ou apenas justiça?}

Ultrapassada a transição e iniciado um processo de consolidação, perdem objeto todas as particularidades de caráter excepcional que definem o momento transicional, em especial a temível ameaça de uma regressão autoritária, haja vista que, em uma democracia consolidada, idealmente, a reversão está, em tese, fora de questão. O discurso político da exceção sai de cena para dar lugar ao respeito dos procedimentos democráticos já rotinizados, aos quais aderiram os atores politicamente relevantes.

Assim, as restrições tão características das transições, com os profundos dilemas éticos e dúvidas estratégicas, além do horizonte de excepcional indefinição, parecem, aos poucos, desocuparem o centro das preocupações políticas.

Por isso, o temor onipresente de uma "morte rápida", tão marcante durante a transição, não tem mais razão de existir. Esse risco é substituído por uma outra modalidade de regressão autoritária, qual seja, nas palavras de O'Donnell, a de uma "morte lenta", que se mostrou muito mais perigosa e ameaçadora. O problema é que essa mudança não é prontamente assimilada no sistema político e, sobretudo, pelos próprios jogadores, pois as alterações nas posições de poder e na correlação de forças não se processam de modo automático e imediato.

Com efeito, como os limites entre a transição e a consolidação, na prática, não são tão nítidos, ainda que algumas mudanças institucionais mais visíveis se verifiquem rapidamente, outras tantas tarefas da consolidação têm ritmo mais lento e vão-se consumando gradualmente. Durante essa fase final da democratização, o maior desafio reside na tendência que os atores políticos têm de perpetuar, por certa inércia advinda do

\footnotetext{
${ }^{330}$ Essa é a pertinente advertência feita por GUILHOT, Nicolas; SCMITTER, Philippe C. De la transition à la consolidation, p. 621 .
} 
costume, as práticas e expectativas que mantinham durante a transição. Aí se colocam as dificuldades para que os agentes democratizadores percebam que não devem mais se orientar por uma lógica do possível, como se a ameaça de um golpe fosse concreta e iminente.

Trata-se de uma profunda questão de cultura política, com efeitos práticos e teóricos. Não que envolva apenas um instalo de lucidez na consciência dos atores ou dos cientistas políticos, como se fosse algo de dimensão exclusivamente objetiva. É evidente que há uma disputa de interesses entre os setores civis-militares que sustentaram os regimes autoritários e os agentes que, de fato, lutaram pela democracia e por sua radicalização até o presente. No entanto, reconhecida essa tensão objetivamente instalada no seio dessas sociedades, que ainda se reviram em torno do legado das suas ditaduras, é preciso ter tranquilidade para assumir a posição de promoção dos princípios democráticos e dos direitos humanos.

Do mesmo modo que assola os atores políticos, esse desafio também interpela as reflexões teóricas que se debruçam sobre essa temática, dado o grau de proximidade que essas questões analíticas guardam com a política real e cotidiana que consideram. Esses autores já sinalizaram a dificuldade de examinar de forma isenta os problemas da democratização, demonstrando a dificuldade de separar-se com precisão o espaço do teórico e o do governante.

Obtendo êxito quanto a esse quesito, de perceber e trabalhar essa distinção entre a transição e a consolidação, amplia-se a margem de ação e o poder de barganha dos atores democráticos, pois um dos bloqueios fundamentais à consolidação, a ameaça de regressão manipulada pelos egressos do regime autoritário, é cada vez mais fragilizado no âmbito do sistema político. Da parte dos analistas, também melhora a qualidade das reflexões. Essa parece ser a tendência corrente, mas que ainda enfrenta diversas resistências e obstáculos postos pelas próprias leituras de conjuntura que incorporam, de modo equivocado, elementos desse passado autoritário.

Essa constatação é fundamental e merece ser bastante frisada, por ter reflexos no modo de percepção e compreensão das tarefas ainda pendentes dos processos de democratização. As nomenclaturas e caracterizações não são aspectos desprezíveis nos movimentos históricos. Nesse caso, utilizar o termo "transição" e seus derivados, especialmente justiça de transição, implica atualizar uma série de pressupostos datados e bastante particulares da transitologia. Pressupostos estes que organizam um esquema 
analítico de alcance e aplicabilidade muito reduzidos, pois elaborado precisamente para dar conta de conjunturas críticas e notoriamente excepcionais.

Justiça de transição, como foi visto, constitui uma experiência social, política e jurídica bastante peculiar, marcada por condições particularíssimas e, por isso, com nítido caráter de exceção. Não por outra razão, carrega em sua própria designação o vocábulo transição. Justamente porque vigem condições que impedem a realização da ideia de justiça em suas configurações normais ou tradicionais, normalmente pelo grau extremo de conflito ainda vivido, é que se faz necessária uma justiça precária, cujos contornos são traçados, prioritariamente, pela lógica da possibilidade, sempre estreita demais para o grau de exigência dos reclamos morais por justiça das vítimas, ainda que sempre levando a opinião destas em conta.

Não há dúvidas, hoje, que os processos de transição democrática, para se ater aos exemplos latino-americanos e sul-europeus, foram vividos e esgotados durante a década de 80. Todos os países dessa região, nessa época, já tinham instituições razoavelmente estabelecidas e procedimentos que guiavam o calendário eleitoral, inclusive com eleições diretas para o cargo maior do Poder Executivo. No entanto, passadas décadas, ainda parece sobreviver o discurso que a fragilidade dessas democracias não permite um acerto de contas integral em relação ao passado, atendendo-se, plenamente, não só às demandas das vítimas e seus familiares, mas também aos tratados internacionais e às ordens constitucionais que consagraram a internalização dessas normas de proteção aos direitos humanos.

O maior questionamento a ser colocado é por que adotar uma terminologia como justiça de transição na fase da consolidação? O que justifica esse uso? Não seria mais pertinente e adequado, mesmo do ponto de vista normativo de construção e aprofundamento de uma democracia de melhor qualidade, falar-se em "justiça de consolidação"? Ou apenas de justiça?

Esse questionamento, estrutural no presente trabalho, tem por intenção principal romper com alguns tipos de lógica que, muitas vezes imperceptivelmente, estão embutidas nos modelos interpretativos e que têm consequências diretas nas estratégias dos próprios atores.

Não raras vezes, emergem no espaço público discursos que, sob o argumento da prudência e da cautela, impõem bloqueios e limitações às medidas transicionais. Reavivam, de alguma maneira, os contextos conflitivos e cheios de intensas mudanças políticas, 
dando-lhes nova atualidade e reafirmando, de modo perverso, porque não assumidos publicamente, esses mesmos conflitos.

Explicando melhor esse aspecto, a verdade é que, em nossos dias, nessas regiões, não se assiste a questionamentos sérios e realmente ameaçadores à democracia, que é tida, sem exageros, como a mais elevada forma de convivência política forjada pelos homens. Todos os atores relevantes, na terminologia cara a essa tradição, hoje participam desse consenso que universaliza a democracia, ao menos enquanto discurso. Ninguém, abertamente, tampouco os setores militares, cogitam saídas autoritárias para as inevitáveis crises da vida política contemporânea. Então, por que razão se deveria perpetuar um raciocínio que assume, como fator preponderante do jogo político, o risco da regressão autoritária, da "morte rápida" dos regimes democráticos?

Daí a centralidade dessa ruptura analítica para redimensionar e reavaliar, à luz do presente, os acontecimentos recentes, de triste memória, nesses países. Isso é ainda mais urgente nas nações onde, como o Brasil, imperam as estratégias da conciliação e do esquecimento, mais do que comprovadas pelo formato da transição experimentada em nosso país, que submeteu os direitos fundamentais das vítimas da repressão política e de seus familiares aos imperativos da estabilidade e da construção de uma nova democracia possível. 


\section{CONCLUSÃO}

A chamada "terceira onda" de democratizações, que tomou o Sul da Europa e os países latino-americanos durante as décadas de 70 e 80, bem como os países do Leste Europeu, recolocou na ordem internacional os problemas decorrentes da sucessão entre regimes políticos. Sem dúvidas, pode-se afirmar que esse conjunto de acontecimentos constitui um dos eventos políticos de maior repercussão teórica durante o século XX.

Se por um lado, como nunca antes na história da humanidade, tantas nações se organizaram politicamente sob a égide de instituições e procedimentos democráticos ou, pelo menos, reivindicaram tal regime, por outro, também, nunca houve um compromisso tão universal, ao menos formalmente proclamado, dos atores políticos e dos intelectuais com a democracia, suas estruturas mínimas e valores básicos.

Nesse sentido, emergiram, nesse rico contexto histórico, diversas análises no campo da ciência política e do direito, com vistas ao tratamento teórico não apenas das transições, mas também das políticas de institucionalização dos novos regimes, processo este conhecido como consolidação democrática. Essa dupla conceitual "transição" e "consolidação" foi, durante anos, a principal preocupação das análises acadêmicas e dos discursos em tornos das disputas do poder nesses Estados.

A definição canônica de transição foi marcada pelo alto grau de incerteza em conjunturas críticas, nos quais as configurações políticas produzidas dependem, antes de tudo, das estratégias postas em prática por um número limitado de atores e suas interações de natureza contingente.

A despeito de suas singularidades, essas análises compartilhavam entre si um traço fundamental: compreendiam as transições essencialmente como momentos de contingência política, em que a imprevisibilidade dos jogos de poder e a incerteza quanto aos resultados dos conflitos sociais eram potencializadas a um nível extremo. Em outros termos, se em períodos de estabilidade política sob regimes democráticos, por definição, a disputa política é sempre uma variável em aberto, nos momentos de excepcionalidade política, essa indefinição do campo político é acentuada de forma marcante. Isso porque, nas transições, as negociações e embates entre os atores políticos relevantes irrompem no 
espaço público com especial destaque, condensando o tempo histórico e ampliando os limites dos conflitos na definição dos destinos da coletividade.

Assim, a vultosa dimensão das tarefas transicionais e a implicação profunda dos atores nelas envolvidos, pareciam compensar-se nessa literatura. Os desafios de influenciar os rumos das mudanças políticas atingiam tanto os defensores do antigo regime quanto os portadores do projeto de uma nova ordem. Eram interesses e motivações de distintos níveis que determinavam a posição dos atores políticos relevantes para o desenlace dos conflitos postos e institucionalizados. Ponto a ponto, a invenção - nem sempre democrática - das soluções políticas durante a sucessão entre regimes podia ser pactuada com ampla margem de liberdade, a depender, essencialmente, apenas dos sujeitos envolvidos e de suas demandas, desde as mais imediatas e pragmáticas - como a não punição dos que estão deixando o controle do Estado - como as mais ideológicas, envolvendo diferentes visões de mundo e projetos de país. Em suma, em um cenário de suspensão das regras que estavam estabilizadas no antigo regime e ainda sem diretrizes claras sobre como seria o futuro, tudo parecia restar à livre negociação e à força performativa da ação política.

Esse peso conferido à dimensão criadora e imaginativa da política é compreensível nessas análises, contextualizadas no bojo das reflexões que animaram uma ciência política que se pretendia capaz de dar conta da especificidade desses fenômenos de maneira autônoma, ou seja, para além das variáveis históricas e econômicas. Todos os tipos de estruturas e condicionantes externos à ação dos sujeitos, permaneceram, nesses autores, em suspenso. Mas um constrangimento, de ordem político-psicológica, manteve sua marcante presença, influenciando profundamente as estratégias e cálculos em torno dos jogos políticos: trata-se do medo de uma regressão autoritária, que funcionava como uma espada de Dâmocles nas transições.

A metáfora é bastante clara. Todos os agentes democratizadores tinham de permanecer atentos a essa ameaça de um novo golpe que, se efetivada, consumaria a frustração do processo transicional e imporia uma "morte rápida" à democracia. Nessa linha, essa possibilidade de regressão deveria ser evitada a todo custo, funcionando, para alguns, como uma ameaça e, para outros, como um blefe permanente, que pesava sobre as escolhas, capaz de consumir boa parte das energias e potencialidades que animavam essas mudanças políticas.

Não por outra razão, nesse contexto, a justiça com relação aos crimes de violação aos direitos humanos, cometidos massivamente por esses regimes autoritários, permanecia como uma questão marginal e menos relevante. Diante do imperativo de estabilizar uma 
nova ordem e sujeitar todos os atores às regras democráticas, desenterrar o passado significaria reavivar conflitos que poderiam comprometer a tranquilidade das transições. As dimensões morais e jurídicas dessas demandas, portanto, eram subjugadas pelas necessidades de ordem política, dados os riscos que se entendiam iminentes nessas frágeis democracias.

No entanto, essa liberdade e essa abertura, outrora definidoras dos momentos autenticamente transicionais e fundantes da política, começaram a ser cada vez mais questionadas a partir do final do século XX. Os abusos de poder, não raro legando massivas e sistemáticas violações de direitos humanos, trouxeram à tona e denunciaram a dimensão nefasta da ausência de princípios mais ou menos universais capazes de conferir um mínimo ético nesses processos políticos. Diversos pactos, nomeadamente aqueles que inauguraram as redemocratizações na América Latina, foram selados em contextos impositivos e nos quais havia uma assimetria de posições de poder entre os diferentes atores. O constrangimento direto, além da permanente ameaça tácita de um regresso autoritário, impunha limitações à justa pactuação das novas ordens pelos interlocutores envolvidos.

Nesse cenário, de certa forma, impuseram-se acertos políticos hoje tidos claramente como precários, como manifestação do possível nas condições adversas que marcam as transições, sob permanente ameaça da interrupção momentânea do processo de democratização, de sua suspensão definitiva ou até mesmo da sua pura e simples regressão, abortando-se as iniciativas de mudança. Os perdões e as anistias concedidas ou autoconcedidas aos perpetradores das violações de direitos humanos são o maior exemplo disso.

O conceito de justiça de transição emerge, então, e precisamente, direcionado a esse tipo de contexto histórico, legado como herança autoritária, mas que funcionou de ponto de partida dos regimes democráticos. A despeito de inúmeras iniciativas pontuais de justiça retroativa (política ou legal), esclarecimentos públicos e reconhecimento de verdade, bem como dos trabalhos de memorialização, nos distintos períodos históricos das diferentes comunidades políticas, foi somente nos últimos vinte anos que uma abordagem mais sistemática e consistente dessas experiências se viabilizou. Para atingir o ponto nevrálgico que caracteriza a especificidade dessa experiência nos tempos atuais, não se pode confundi-la com momentos da história da humanidade em que alguns tipos dessas experiências se verificaram, isoladamente ou mesmo combinadas entre si, sem a organicidade que hoje carrega. 
Em essencial, a emergência de uma justiça democrática e global é um exemplo privilegiado de um processo mais amplo de intensa globalização e de internacionalização da proteção e da promoção dos direitos humanos, naquilo que foi chamado de "regime pósWestfaliano de direitos humanos". Papel central, nesse aspecto, têm as diversas jurisdições supranacionais, que incorporam tarefas e funções antes relegadas exclusivamente às estruturas constitucionais tradicionais, restritas às fronteiras do Estado-nação. A partir dessas estruturas de oportunidades básicas, é que se conseguiu afirmar uma rede de litigância estratégica fundamental para a efetivação dos direitos humanos.

Nesse sentido, deslocou-se parcela importante das linhas de força que dava contornos às transições desde o campo da política para o do direito. Mudou-se, em alguma medida, o epicentro das políticas de direitos humanos. Não que a transição deixe de ser contingente ou que o direito suprima o espaço da política enquanto locus privilegiado e por excelência da discussão de alternativas, da deliberação dos rumos e da organização em geral de determinada comunidade. No entanto, é fato que as revisões e anulações de diversos acordos políticos de transição, anos e até décadas após a celebração dos mesmos, atestam exatamente essa nova situação, caracterizada por um protagonismo político importante das instâncias jurisdicionais nas democracias contemporâneas. Nesse cenário de judicialização da política e de internacionalização das garantias básicas, tanto as Cortes Supremas nacionais como as Cotes Internacionais e Regionais atuam intensamente nesse campo $^{331}$.

Pode-se afirmar que a natureza contingente das transições, que as permitia dispor dos direitos ao sabor dos jogos de poder, começou a ser seriamente questionada. As variáveis e o alcance das mudanças políticas passaram a ser restringidos, ainda que a posteriori e retroativamente, pela mobilização política e jurídica em torno dessas normas de proteção internacional dos direitos humanos, que acabaram demonstrando certa ascendência sobre o antigo "enquadramento Keynesiano-Wesfaliano" da justiça.

Esse conceito, hoje, passa centralmente pelas limitações anunciadas e tácitas são impostas às negociações e pactos transicionais, reduzindo a tirania da política e nutrindo a impositividade do direito, inclusive como fonte de legitimidade e não apenas de legalidade

${ }^{331}$ Exemplo notável é o caso das leis de anistia ou perdão que foram editadas nas transições democráticas latino-americanas. No Cone Sul, o Brasil é o único país que ainda sustenta a vigência de sua lei de anistia, abrangendo também os agentes públicos que praticaram crimes de violação aos direitos humanos, ainda que haja condenação expressa e vinculante da Corte Interamericana dos Direitos Humanos exigindo a remoção dos obstáculos jurídicos existentes para a persecução penal desses agentes. Com efeito, Argentina, Uruguai, Paraguai e Chile já contam com importantes iniciativas nos trabalhos de memória e justiça, campo ainda que se começa a explorar em nosso país. 
nesses processos instáveis. É preciso evidenciar que os limites éticos e jurídicos postos às transições políticas não são arbitrariedades ou versões de ocasião elaboradas por aqueles tidos como vencedores da história. Trata-se de um padrão mínimo civilizatório de universalização de garantias e direitos, reconhecidamente de inspiração ocidental, que devem passar ser considerados em qualquer conjuntura particular, ainda que com variações.

A justiça de transição, desse modo, em sua historicidade própria, só faz sentido se compreendida a partir desse reenquadramento da ideia de uma transição justa nessa nova conformação de uma experiência político-jurídico contemporânea, que agrega novos elementos e balizas ao Estado de Direito no cenário global. Mais do que algumas dimensões ou eixos, a justiça de transição é um capítulo privilegiado da internacionalização dos campos jurídicos, em especial dos direitos humanos, que reduzem a capacidade política do Estado e dos atores nacionais no que se refere às garantias mínimas e liberdades fundamentais dos seus cidadãos. Esse é seu sentido maior.

Por essa razão, entendemos ser necessário deixar um pouco de lado a perspectiva já tradicional da justiça de transição eminentemente fenomenológica, pois centrada nas diversas manifestações e partes componentes dessa experiência. Ainda que envolva dimensões que dizem respeito à garantia da verdade e da memória, à reforma profunda das instituições no sentido de democratizá-las, bem como às medidas de justiça que reparem as violações do passado e reforcem o imperativo da não repetição, não se pode construir o conceito meramente unindo essas parcelas, como se a soma das partes fosse suficiente para dar conta do todo.

Em verdade, a ciência política teorizou as transições como objeto privilegiado de reflexão e, em seguida, virou essa página ao dedicar-se de maneira mais intensa aos problemas do que ficou conhecido como consolidação democrática, dedicando-se sobretudo aos problemas postos pelo funcionamento das instituições nessa nova conjuntura. A partir de então, entraram os pensadores da área jurídica para aportar uma relevante contribuição em relação aos processos de constitucionalização e fundação de novas ordens legais no bojo das redemocratizações. Essa espécie de divisão tácita de tarefas que se estabeleceu e que, salvo exceções, tem-se mantido até os tempos mais recentes fizeram com que os diálogos entre a ciência política e o direito ficassem prejudicados quanto às matérias transicionais.

Aí desponta outro fator marcante que sintomatiza, com especial evidência, essas transformações: trata-se do papel desempenhado pelo direito nas transições tais como concebidas na história latino-americana e das atuais formulações sobre esse tema. Antes, o 
direito assumia uma função de formalização dos pactos políticos negociados, consagrando um patamar mínimo de garantias do liberalismo clássico. Esse patamar foi elevado substancialmente com a incorporação, nas experiências jurídico-institucionais contemporâneas, da justiça de transição e do direito internacional dos direitos humanos. A partir de então, o direito impôs uma série de restrições aos poderes constituídos, as quais, de algum modo, alteraram até mesmo as prescrições pactuadas no momento fundacional do poder constituinte originário.

As transições, que habitualmente processavam-se nos circuitos políticos, passaram a ser informadas, com peso, pelas influências do direito. Outrora prospectivas, adotando uma perspectiva unilateral de pacificação em detrimento da justiça, as transições passam a ser vistas também como momentos privilegiados para se olhar o passado e efetivar-se uma reparação tanto daqueles que sofreram diretamente as violações de direitos humanos, como da sociedade.

Como discutido, a retomada das transições, enquanto problema teórico sob a perspectiva da justiça, surge com força apenas na última década do séc. XX, a partir de reflexões preocupadas em catalogar diferentes experiências e, indutivamente, forjar regras mais gerais ou padrões de comportamento dos atores nesses processos. Contudo, do mesmo modo como se construiu um conceito, estava também selado o caminho para a redução da justiça de transição a um conjunto de medidas mais ou menos universais, de caráter institucionalista e ainda muito limitado, porque restrito aos direitos humanos tidos como mais fundamentais ou primitivos, nomeadamente os civis e políticos.

A justiça transicional, é verdade, organizou, na condição de referência tópica e conceitual, uma importante reflexão que permitiu sistematizar os desafios postos para ampliar os processos de efetiva democratização. Demarcou todo um campo analítico que tem permitido, malgrado alguns problemas apontados criticamente no capítulo segundo dessa pesquisa, a compreensão das tarefas que precisam ser levadas a cabo e de algumas políticas importantes para reparar as violações de direitos humanos do passado e evitar a ocorrência de episódios semelhantes no futuro.

No entanto, todo esse arcabouço teórico parece fadado a repetir os mesmos equívocos da transitologia, havendo diversas razões que justificam essa preocupação conceitual. Como complementação desse primeiro campo de investigações (ainda que não se assumindo enquanto tal), veiculou uma pretensão de universalidade extremada demais, do mesmo modo da subdisciplina que lhe deu origem, a ponto de comprometer seus potenciais explicativos. Sua utilização indiscriminada, para situações marcadamente 
distintas entre si e para países que vivem momentos históricos bastante diferentes, acaba esvaziando o sentido dessa construção conceitual. Também, não raras vezes, assumiu uma teleologia pouco problematizada, impingindo uma normatividade (implícita) ao desenvolvimento histórico que precisa ser, no mínimo, discutida.

Por isso, assim como ocorreu nos estudos da transitologia e, mais recentemente, da consolidologia, também a justiça de transição precisa ser submetida a uma avaliação crítica, com o objetivo de depurar cuidadosamente essa teorização. Não se pode permitir que, passadas duas décadas do início da utilização mais corrente da expressão, continue-se apenas a repetir a mesma estrutura conceitual nos diversos estudos empíricos mundo afora. Após esse relativo distanciamento histórico, é preciso conferir-lhe maior rigor teórico, atribuindo-lhe apenas as capacidades heurísticas e as tarefas explicativas que é capaz de assumir.

Vale ressaltar que o presente trabalho não coloca em questão a importância deste conceito e de sua positivação, a duras penas, no campo do direito internacional dos direitos humanos. São louváveis suas consagrações na maior parte das diversas políticas públicas que se proliferaram sobre esse tema. Tampouco se questionam, substancialmente, o conjunto de medidas e mecanismos que costumam ser mobilizados para compor essa experiência de buscar a justiça possível em condições adversas.

Ao contrário, o que se sustenta é que, para fazer jus à importância do conceito para o mundo atual, é necessário ultrapassar a maneira corrente de encará-lo, a partir somente de uma descrição de seu conteúdo composto pelos eixos clássicos. Até mesmo porque há uma tendência de que, com a crescente internacionalização da promoção dos direitos humanos, esse conteúdo permaneça sempre em expansão, o que constantemente recolocará em questão essas descrições limitadoras. Portanto, é preciso avançar em um exame analítico de suas próprias estruturas, aclarando as potencialidades e limitações de sua aplicação para cada tipo de situação.

Em outras palavras, não se sugere aqui uma mudança radical nas práticas de justiça transicional. Os direitos à verdade, memória, justiça, reparação e as reformas institucionais são fundamentais para superar os legados da violência sistemática e generalizada. O objetivo aqui é apenas atirar luz sobre alguns aspectos que têm sido negligenciados na pragmaticidade que marca a conversão rápida demais de um conceito analítico em política pública institucionalizada. É preciso, nesse sentido, definir melhor seu escopo, circunstâncias e âmbito de aplicação. Essas iniciativas são necessárias, inclusive, para conferir maior potencial de intervenção e eficácia a esse tipo de abordagem. 
Nesse particular, não há dúvidas de que as situações políticas latino-americanas e sul-europeias hoje são diferentes daquelas descritas nas análises expostas no primeiro capítulo. $\mathrm{O}$ espectro do autoritarismo já não ronda a democracia como uma ameaça tão amedrontadora nessas regiões.

Por isso, é fundamental que se rompa, nesses casos, com o discurso que legitima um tipo de justiça extremamente frágil, incompleta e precária. Não se verificam as mesmas condições adversas e fragilidades institucionais que justificariam uma "justiça do possível", ainda que também não se afirme, em um extremo oposto de otimismo, que as democracias atuais estejam inteiramente consolidadas e em funcionamento ideal nesses países.

O conceito de justiça de transição é inadequado ao atual contexto latinoamericano, justamente, por sinalizar um tipo de justiça provisória e momentânea, como a justiça possível em determinada conjuntura delicada de profundas transformações em curso. A transposição a outros contextos demanda profunda reflexão, por razões evidentes, sendo possível utilizá-lo apenas se feitas as devidas ressalvas. E, no caso de utilizá-lo para contextos não transicionais, deve-se questionar, antes, se não há conceito mais apropriado.

Isso porque, como se tentou demonstrar, a utilização deste conceito permite a perpetuação de uma ameaça tácita e sempre presente de regresso autoritário, como se um pacto frágil sustentasse todo o Estado de Direito e suas instituições. Por essa razão, seria mais adequado trabalhar com a ideia de Estado de Direito atravessado por uma ordem internacional que tem em alta conta os direitos humanos e que é capaz de conjugar essas vinculações com sua soberania. Passa a viger uma espécie de rule of law mesmo durante as transições. Com isso, não se visa mais, apenas, evitar a temida regressão autoritária, mas essencialmente melhorar o nível e a qualidade da democracia recentemente instituída.

Desenterrar esse passado exige, necessariamente, quebrar com o fantasma de uma eterna transição, que nunca se consuma e que, por isso, assombra o regime democrático fazendo-lhe lembrar, a todo momento, que qualquer passo mais ousado pode significar uma precipitação de um fim trágico, sempre virtualmente apontado no horizonte.

Tornar permanente a exceção e normalizar o discurso sobre a transição a outras conjunturas, como o faz a justiça de transição usada sem rigor, são procedimentos que acarretam um risco enorme. Em particular, acabam por generalizar e perpetuar indefinidamente a situação tensa e, por definição, excepcional da transição, ou seja, legitimar pelo discurso a ameaça permanente e a exceção interminável. Faz-se, assim, o jogo não da consumação da transição, mas alimentam-se sua indefinição e sua limitação, 
impedindo a efetiva construção democrática. Chancela-se, assim, a "morte lenta", agregando mais um capítulo à lógica da possibilidade restrita e da conciliação imposta.

Dessa maneira, é possível também desfazer-se da ideia, bastante perniciosa, de que o autoritarismo seria apenas uma exceção na normalidade, um intervalo no curso normal de uma ordem democrática, tida como regra quase natural da convivência humana. Isso é fundamental para compreenderem-se os traços de autoritarismo atuantes na vida democrática. Nunca é demais frisar que a construção democrática, sem uma ameaçadora Espada de Dâmocles dependurada sobre os atores políticos, exige muito mais do que uma evolução inscrita no processo histórico, como algumas vezes esse etapismo sugere. No mínimo, demanda uma ação persistente e coordenada de atores que se identifiquem, no plano dos valores e crenças, com esse compromisso democrático.

Como fora notado, as teorias da transitologia e da consolidologia, a despeito das explicações importantes que ofereceram nessas difíceis épocas, apresentam diversas limitações e insuficiências, algumas insolúveis nos marcos teóricos eleitos por esses autores. Mas, se para fim de argumentação e apenas momentaneamente, é preciso valer-se dessa binariedade entre transição e consolidação, como momentos singulares e com características até contraditórias entre si, não resta dúvida de que a ideia de uma "justiça de consolidação" soaria melhor diante dos atuais desafios postos para a melhora da qualidade da democracia na região da América Latina e da Europa do Sul. Ou apenas o termo "justiça”, sem adjetivos.

Pois pior do que adotar o etapismo dessa tradição, seria adotá-lo de maneira equivocada e invertida, tomando consolidação por transição como tem acontecido. Essa é a contribuição crítica desse trabalho, chamando a atenção para esse aspecto que parece minimizado nas reflexões tradicionais sobre a justiça transicional. 


\section{REFERÊNCIAS BIBLIOGRÁFICAS}

ALMEIDA, Leonel Itaussu de. Golbery revisitado: da abertura controlada à democracia tutelada. In: MOISÉS, José Álvaro; ALBUQUERQUE, José A. Guilhon (Org.). Dilemas da consolidação da democracia. Rio de Janeiro: Paz e Terra, 1989.

ALSTON, Philip. Relatório do Relator Especial sobre Execuções Extrajudiciais, Sumárias ou Arbitrárias. 2008. Disponível em: <www.nevusp.org/downloads/relatoriophilip.doc>. Acesso em: 15 jan. 2012.

AVRITZER, Leonardo. Cultura política, atores sociais e democratização: uma crítica às teorias da transição para a democracia. Revista Brasileira de Ciências Sociais, São Paulo, v. 10, n. 28, 1995. Disponível em: $<\mathrm{http}$ //www.anpocs.org.br/portal/publicacoes/rbcs_00_28/rbcs28_09.htm>. Acesso em: 20 dez. 2011.

BATISTA, Nilo. Nota Introdutória. In: DIMOULIS, Dimitri; MARTINS, Antonio; SWENSSON JUNIOR, Lauro Joppert (Org.). Justiça de Transição no Brasil: Direito, responsabilização e verdade. São Paulo: Saraiva; Direito GV, 2010.

BAXTER, Victoria. Critical challenges for the development of the transitional justice research field. In: .; MERWE, Hugo Van Der; CHAPMAN, Audrey R. (Ed.). Assessing the impact of transitional justice. Washington DC: United States Institute of Peace, 2009. p. 325-333.

BICUDO, Hélio. Lei da anistia e crimes conexos. In: TELES, Janaína (Org.). Mortos $e$ desaparecidos políticos: reparação ou impunidade?. São Paulo: Humanitas FFLCH/USP, 2001.

BOBBIO, Norberto; MATTEUCCI, Nicola; PASQUINO, Gianfranco (Org.). Dicionário de Política. Brasília: UnB, 1986 [1983].

BRANCO, Marcello Simão. Da transição dos anos 80 para o início do século XXI: uma discussão teórica e comparativa da democratização na América Latina. São Paulo, 2002. Dissertação (Mestrado em Ciência Política) - Faculdade de Filosofia, Letras e Ciências Humanas, Universidade de São Paulo.

BROWN, Chris. Sovereignty, rights and justice: international political theory today. Cambridge: Polity, 2006 [2002].

BUNCE, Valerie. Quand le lieu compte: specificités des passés autoritaires et réformes économiques dans les transitions à la democratie. Revue Française de Science Politique, Paris, v. 50, n. 4-5, p. 633-656, ago./ out. 2000.

CAROTHERS, Thomas. The End of the Transition Paradigm. Journal of Democracy, v. 13, n. 1, p. 5-21, 2002. 
CAVALlARO, James; ALBUJA, Sebastián. The lost agenda: economic crimes and truth comissions in Latin America and beyond. In: MCEVOY, Kieran; MCGREGOR, Lorna (Ed.). Transitional Justice from Below: Grassroots Actvism and the Struggle for Change. Oxford; Portland: Hart, 2008. p. 121-141.

CHAPMAN, Audrey R. Truth finding in the transitional justice process. In: MERWE, Hugo Van Der; BAXTER, Victoria (Ed.). Assessing the impact of transitional justice. Washington DC: United States Institute of Peace, 2009. p. 91113.

CÍCERO, Marco Túlio. Tusculan Disputations. New York: Harper \& Brothers, 1877 [708 a.C.]. Disponível em: <http://www.gutenberg.org/files/14988/14988-h/14988-h.htm>. Acesso em: 15 jan. 2012.

CIOFFI-REVILLA, Claudio. Politics and uncertainty: theory, models and applications. Cambridge: Cambridge University, 1998.

COETZEE, J. M. À espera dos bárbaros. São Paulo: Companhia das Letras, 2006.

COHEN, Jean. Sociedade Civil e Globalização: Repensando Categorias. DADOS - Revista de Ciências Sociais, Rio de Janeiro, v. 46, n. 3, p. 419-459, 2003.

COMBLIN, Pe. Joseph. A ideologia da segurança nacional: o poder militar na América Latina. Rio de Janeiro: Civilização Brasileira, 1978.

COMPARATO, Fábio Konder. A responsabilidade do Estado brasileiro na questão dos desaparecidos durante o regime militar. In TELES, Janaína (Org.). Mortos e desaparecidos políticos: reparação ou impunidade?. São Paulo: Humanitas FFLCH/USP, 2001.

COSTA, Sergio. Movimentos sociais, democratização e a construção de esferas públicas locais. Revista Brasileira de Ciências Sociais, São Paulo, v. 12, n. 35, out. 1997. Disponível em: $<\mathrm{http}$ //www.scielo.br/scielo.php?script=sci_arttext\&pid=S0102$69091997000300008 \& \operatorname{lng}=$ en\&nrm=iso $>$. Acesso em: 20 dez. 2011.

CUEVA, Eduardo González. Perspectivas teóricas sobre la justicia transicional. Disponível em: $<$ http://www.cnrr.org.co/interior_otros/pdf/justran/Gonzalez_Cueva.pdf $>$. Acesso em: 20 dez. 2011.

DAHL, Robert. Poliarchy: participation and opposition. London: Yale University, 1971.

DALLARI, Dalmo de Abreu. Crimes sem anistia. In: TELES, Janaína (Org.). Mortos $e$ desaparecidos políticos: reparação ou impunidade?. São Paulo: Humanitas FFLCH/USP, 2001.

DIAS, José Carlos. Os desaparecidos. In: TELES, Janaína (Org.). Mortos e desaparecidos políticos: reparação ou impunidade?. São Paulo: Humanitas FFLCH/USP, 2001. 
DIMOULIS, Dimitri. Justiça de transição e função anistiante no Brasil. Hipostasiações indevidas e caminhos de responsabilização. In: ; MARTINS, Antonio; SWENSSON JUNIOR, Lauro Joppert (Org.). Justiça de Transição no Brasil: Direito, responsabilização e verdade. São Paulo: Saraiva; Direito GV, 2010.

DOBRY, Michel. Les transitions démocratiques regards sur l'état de la 'transitologie'. Revue Française de Science Politique, Paris, v. 50, n. 4-5, p. 615-631, ago./out. 2000.

ELSTER, Jon. Closing the books: transitional justice in historical perspective. New York: Cambridge University, 2004.

Preference formation in transitional justice. In: KATZNELSON, Ira; WEINGAST, Barry (Ed.). Preferences and situations: points of intersection between historical and rational choice institucionalism. New York: Russel Sage Foundation, 2005.

FARIA, José Eduardo. Os direitos humanos e o dilema latino-americano às vésperas do século XXI. Novos Estudos CEBRAP, São Paulo, n. 38, p. 61-78, mar. 1994.

Direitos humanos e globalização econômica: notas para uma discusão. Estudos Avançados, São Paulo, v. 11, n. 30, ago. 1997. Disponível em: $<$ http://www.scielo.br/scielo.php?script=sci_arttext\&pid=S0103-40141997000200004>. Acesso em: 20 dez. 2011.

- A globalização econômica e sua arquitetura jurídica (dez tendências do direito contemporâneo). Disponível em: $<$ http://moodle.stoa.usp.br/file.php/491/8.1._Faria_A_globalizacao_economica_e_sua_arquitetura_juridica.pdf $>$. Acesso em: 15 jan. 2012 .

.; CAMPILONGO, Celso. Sociologia jurídica no Brasil. Porto Alegre: Sergio Antonio Fabris, 1991.

FORST, Rainer. A critical theory of transnational justice. In: POGGE, Thomas W. Global justice. Malden; Oxford: Blackwell, 2001. p. 169-187.

FREEMAN, Mark. Necessary Evils: Amnesties and the search for justice. Cambridge: Cambridge University, 2009.

FRASER, Nancy. Reenquadrando a justiça em um mundo globalizado. Lua Nova: Revista de Cultura e Política, São Paulo, 77, p. 11-39, 2009. Disponível em: $<$ http://www.scielo.br/pdf/ln/n77/a01n77.pdf $\geq$. Acesso em: 20 dez. 2011.

GODELIER, Maurice. The processes of transtition. International social science journal, $\mathrm{n}$. 114, p. 447-458, nov. 1987.

GRAY, David. An excused-centered approach to transitional justice. Fordham Law Review, n. 74, 2006, p. 2621-2694. Disponível em: $<$ http://digitalcommons.law.umaryland.edu/fac_pubs/632/ > Acesso em: $20 \mathrm{dez}$. 2011. 
GREIFF, Pablo. International courts and transitions to democracy. Public Affairs Quarterly, v. 12, n. 1, p. 79-99, jan. 1998. Disponível em: $<\mathrm{http}: / /$ www.jstor.org/pss/40436007>. Acesso em: 20 dez. 2011.

GRYNSZPAN, Mario. A Teoria das Elites e sua Genealogia Consagrada. In: BIB - Revista Brasileira de Informação Bibliográfica em Ciências Sociais, n. 41, p. 35-83, 1996.

GUILHOT, Nicolas; SCMITTER, Philippe C. De la transition à la consolidation: une lecture rétrospective des democratization studies. Revue Française de Science Politique, v. 50, n. 4-5, p. 615-631, ago./out. 2000.

HAYNER, Priscilla B. Unspeakable truths: confronting state terror and atrocity. New York: Routledge, 2001.

HAZAN, Pierre. Transitional justice after september 11: a new rapport with Evil. In: ; SHAW, Rosalind; WALDORF, Lars (Ed.). Localizing transicional justice: interventions and priorities after mass violence. Stanford: Stanford University, 2010. p. 49-65.

HOLLANDA, Cristina Buarque de. Teoria das Elites. Rio de Janeiro: Zahar, 2011.

HUMAN RIGHTS WATCH. Força Letal: Violência Policial e Segurança Pública no Rio de Janeiro e em São Paulo. 2009. Disponível em: <http://www.hrw.org/node/87056>. Acesso em: 15 jan. 2012.

HUNTINGTON, Samuel P. A terceira onda: a democratização no final do século XX. São Paulo: Ática, 1994.

A ordem política nas sociedades em mudança. Rio de Janeiro: Forense Universitária; São Paulo: EDUSP, 1975.

KEHL, Maria Rita. Tortura e sintoma social. In: TELES, Edson; SAFATLE, Vladimir. $O$ que resta da Ditadura. Coleção Estado de Sítio. São Paulo: Boitempo, 2010- p. 123132.

KRITZ, Neil. Transitional Justice: How Emerging Democracies Reckon with Former Regimes. v. I, II e III. Washington DC: United States Institute of Peace, 1995.

Policy implications of empirical research on transitional justice. In: MERWE, Hugo Van Der; BAXTER, Victoria; CHAPMAN, Audrey R. (Ed.). Assessing the impact of transitional justice. Washington DC: United States Institute of Peace, 2009. p. 13-21.

KUCINSKI, Bernardo. K. . São Paulo: Expressão Popular, 2011.

LEVINSON, Sanford. Trials, comissions, and investigating comittees: the elusive search for norms of due process. In: ROTBERG, Robert; THOMPSON, Dennis (Ed.). Truth v. Justice: the morality of truth comissions. Princeton: Princeton University, 2000. p. 211-234. 
LINZ, Juan; STEPAN, Alfred. A transição e consolidação da democracia: a experiência do Sul da Europa e da América do Sul. São Paulo: Paz e Terra, 1999.

LOWENTHAL, Abraham F. Prefácio. In: O’DONNELL, Guillermo; SCHMITTER, Philippe C. Transições do regime autoritário: primeiras conclusões. São Paulo: Vértice; Revista dos Tribunais, 1988 [1986].

LUTZ, Ellen. Transitional justice: lessons learned and the road ahead. In: ROHTARRIAZA, Naomi; MARIEZCURRENA, Javier (Ed.). Transitional justice in the twenty-first century: beyond truth versus justice. New York: Cambridge University, 2008 [2006]. p. 325-341.

; SIKKINK, Kathryn. Justice cascade: the evolution and impact of foreign human rights trials in Latin America. Chicago Journal of International Law, v. 2, 2001. p. 134.

MACPHERSON, Crawford Brough. La democracia liberal y su epoca. Buenos Aires: Alianza, 1991.

MAINWARING, Scott. Transitions to democracy and the democratic consolidation: theoretical and comparative issues. In: __ _; O'DONNELL, Guillermo; VALENZUELA, J. Samuel (Ed.). Issues in Democratic Consolidation: the New South American Democracies in Comparative Perspective. Notre Dame: University of Notre Dame, 1992. p. 294-341.

; O’DONNELL, Guillermo; VALENZUELA, J. Samuel (Ed.). Issues in Democratic Consolidation: the New South American Democracies in Comparative Perspective. Introduction. Notre Dame: University of Notre Dame, 1992.

MAQUIAVEL, Nicolau. O príncipe. São Paulo: Penguin Classics Companhia das Letras, 2010.

MARTINS, Luciano. A “liberalização" do regime autoritário no Brasil. In: O’DONNELL, Guillermo; SCHMITTER, Philippe C.; WHITEHEAD, Laurence. Transições do regime autoritário: América Latina. São Paulo: Vértice; Revista dos Tribunais, 1988.

. Ação política e governabilidade na transição brasileira. In: MOISÉS, José Álvaro; ALBUQUERQUE, José A. Guilhon (Org.). Dilemas da consolidação da democracia. Rio de Janeiro: Paz e Terra, 1989.

MCEVOY, Kieran. Letting go of legalism: developing a 'thicker' version of transional justice. In: ; MCGREGOR, Lorna (Ed.). Transitional Justice from Below: Grassroots Actvism and the Struggle for Change. Oxford and Portland, Oregon: Hart, 2008. p. 15-45.

.; MCGREGOR, Lorna. Transitional Justice from Below: An agenda for research, policy and praxis. In: . (Ed.). Transitional Justice from Below: Grassroots Actvism and the Struggle for Change. Oxford and Portland, Oregon: Hart, 2008. p. 1-13. 
MÉNDEZ, Juan E. In defense of transitional justice. In: MCADAMS, A. James. Transitional justice and the rule of law in new democracies. Notre Dame: University of Notre Dame, 2001. p. 1-26.

MERWE, Hugo Van Der. Delivering justice during transition: research challenges. In: .; BAXTER, Victoria; CHAPMAN, Audrey R. (Ed.). Assessing the impact of transitional justice. Washington DC: United States Institute of Peace, 2009. p. 115142.

MEZAROBBA, Glenda. O que é justiça de transição? Uma análise do conceito a partir do caso brasileiro. In: SOARES, Inês Prado; KISHI, Sandra (Coord.). Memória e verdade: a justiça de transição no Estado Democrático brasileiro. Belo Horizonte: Fórum, 2009. p. 37-53.

MIHAI, Mihaela. Julgamentos penais em períodos de transição e o desafio das emoções: histórias de dois países. Revista Crítica de Ciências Sociais, Coimbra, n. 88, p. 155$184,2010$.

MINOW, Martha. Between vengeance and forgiveness: facing history after genocide and mass violence. Boston: Beacon, 1998.

MOISÉS, José Álvaro. Entre a "incerteza" e a tradição política: uma crítica da primeira geração de estudos da transição. Novos Estudos CEBRAP, São Paulo, n. 40, p. 88100, nov. 1994.

; ALBUQUERQUE, José A. Guilhon. Apresentação. In: MOISÉS, José Álvaro; ALBUQUERQUE, José A. Guilhon (Org.). Dilemas da consolidação da democracia. Rio de Janeiro: Paz e Terra, 1989.

.; SADEK, Maria Tereza A. Perspectivas de consolidação democrática na América Latina. São Paulo em Perspetiva, São Paulo, v. 9, n. 1, p. 169-177, 1995.

MUNCK, Gerardo L.; LEFF, Carol Skalnik. Modos de transição em perspectiva comparada. Lua Nova: Revista de Cultura e Política, São Paulo, n. 40/41, p. 69-95, 1997.

NINO, Carlos. Juicio al mal absoluto. Buenos Aires: Emecé; Ariel, 2006.

O’DONNELL, Guillermo. Contrapontos: autoritarismo e democratização. São Paulo: Vértice; Revista dos Tribunais, 1986.

; SCHMITTER, Philippe C. Transições do regime autoritário: primeiras conclusões. São Paulo: Vértice; Revista dos Tribunais, 1988 [1986].

- Transições, continuidades e alguns paradoxos. In: ;) REIS Fábio Wanderley (Org.). A democracia no Brasil: dilemas e perspectivas. São Paulo: Vértice; Revista dos Tribunais, 1988. . Análise do autoritarismo burocrático. Rio de Janeiro: Paz e Terra, 1990. 
O’DONNELL, Guillermo. Prefácio. In: MOISÉS, José Álvaro; ALBUQUERQUE, José A. Guilhon (Org.). Dilemas da consolidação da democracia. Rio de Janeiro: Paz e Terra, 1989.

. Poliarquias e (In)efetividade da lei na América Latina: uma conclusão parcial. In: .; MENDEZ, Juan F.; PINHEIRO, Paulo Sérgio (Org.). Democracia, violência e injustiça: o Não-Estado de Direito na América Latina. São Paulo: Paz e Terra, 2000.

. Introdução aos casos latino-americanos. In: .; SCHMITTER, Philippe C.; WHITEHEAD, Laurence (Org.). Transições do regime autoritário: América Latina. São Paulo: Vértice: Revista dos Tribunais, 1988.

OLSEN, Tricia; PAYNE, Leigh; REITER, Andrew. Transitional Justice in balance: comparing processes, weighing efficacy. Washington: United States Institute of Peace, 2010.

OKELLO, Moses Chrispus. Elevating transitional local justice or crystalizing global governance. In: SHAW, Rosalind; WALDORF, Lars; HAZAN, Pierre (Ed.). Localizing transicional justice: interventions and priorities after mass violence. Stanford: Stanford University, 2010. p. 275-284.

ORGANIZAÇÃO DAS NAÇÕES UNIDAS. O Estado de Direito e a justiça de transição em sociedades em conflito ou pós-conflito. Anistia Política e Justiça de Transição, Brasília, Ministério da Justiça, n. 1, p. 320-351, jan./jun. 2009.

PAYNE, Leigh; ABRÃO, Paulo; TORELLY, Marcelo (Org.). A anistia na era da responsabilização: o Brasil em perspectiva internacional e comparada. Brasília: Ministério da Justiça, Comissão de Anistia; Oxford: Oxford University, Latin American Centre, 2011.

PEREIRA, Anthony W. Ditadura e repressão: O autoritarismo e o estado de direito no Brasil, no Chile e na Argentina. São Paulo: Paz e Terra, 2010.

PINHEIRO, Paulo Sérgio. Autoritarismo e transição. Revista da USP, São Paulo, n. 9, p. 45-56, mar./maio 1991.

. Introdução: os Estados de Direito e os Não-Privilegiados na América Latina. In: .; MENDEZ, Juan F.; O'DONNELL, Guillermo (Org.). Democracia, violência e injustiça: o Não-Estado de Direito na América Latina. São Paulo: Paz e Terra, 2000.

. Esquecer é começar a morrer. In: SOARES, Inês Prado; KISHI, Sandra (Coord.). Memória e verdade: a justiça de transição no Estado Democrático brasileiro. Belo Horizonte: Fórum, 2009. p. 11-18.

POSNER, Eric; VERMEULE, Adrian. Transitional justice as ordinary justice. Public Law and Legal Theory Paper Working Paper, University of Chicago, mar. 2003. Disponível em: <http://www.law.uchicago.edu/files/files/40.eapav.transitional.both_.pdf $>$. Acesso em: 20 dez. 2011. 
PRZEWORSKI, Adam. Democracy and market: political and economic reforms in Eastern Europe and Latin American. Cambridge: Cambridge University, 1991.

Como e onde se bloqueiam as transições para a democracia?. In: MOISÉS, José Álvaro; ALBUQUERQUE, José A. Guilhon (Org.). Dilemas da consolidação da democracia. Rio de Janeiro: Paz e Terra, 1989.

. The games of transition. In: MAINWARING, Scott; O'DONNELL, Guillermo; VALENZUELA, J. Samuel (Ed.). Issues in Democratic Consolidation: the New South American Democracies in Comparative Perspective. Notre Dame: University of Notre Dame, 1992. p. 105-152.

. Amas a incerteza e serás democrático. Novos Estudos CEBRAP, São Paulo, n. 9, p. 36-46, jul. 1984.

QUINALHA, Renan Honório; SOARES, Inês Prado. A memória e seus abrigos: considerações sobre os lugares de memória e seus valores de referência. Anistia Política e Justiça de Transição, Brasília, Ministério da Justiça, n. 4, p. 250-278, jul./dez. 2010.

ROMANO, Cesare P. R. The proliferation of international judicials bodies: the pieces of the puzzle. New York University Journal of International Law and Politics, v. 31, p. 709-751, 1999.

ROTH-ARRIAZA, Naomi. The Pinochet effect: transnational justice in the age of human rights. Pennsylvania: University of Pennsylvania, 2005.

; BERNABEU; Almudena. Justicia transnacional como un proceso híbrido. In: ALMQVIST, Jéssica; ESPÓSITO, Carlos. Justicia transicional en Iberoamérica. Madrid: Centro de Estudios Políticos y Constitucionales, 2009. p. 293-311.

SAID, Edward W. Orientalismo: o Oriente como invenção do Ocidente. São Paulo: Companhia de Bolso, 2007.

SALLUM JÚNIOR, Brasilio. Labirintos: dos generais à Nova República. São Paulo, 1996. Tese (Livre-Docência em Sociologia) - Faculdade de Filosofia, Letras e Ciências Humanas, Universidade de São Paulo.

SANCINETTI, Marcelo; FERRANTE, Marcelo. El derecho penal en la protección de los derechos humanos: la protección de los derechos humanos mediante el derecho penal en las transiciones democráticas. Buenos Aires: Hammurabi, [s.d].

SANGUINETTI, Julio María. Present at transition. In: DIAMOND, Larry; PLATTNER, Marc F. (Ed.). The global resurgence of democracy. Baltimore: The Johns Hopkins University, 1993. p. 53-60.

SANTISO, Javier. La démocratie incertaine: la théorie des choix rationnels et la démocratisation en Amérique latine. Revue Française de Science Politique, Paris, v. 43, n. 6, p. 970-993, dez. 1993. 
SANTOS, Cecília MacDowell. A justiça ao serviço da memória: mobilização jurídica transnacional, direitos humanos e memória da ditadura. In: ; TELES, Edson; TELES, Janaína de Almeida (Org.). Desarquivando a ditadura: memória e justiça no Brasil. v. II. São Paulo: HUCITEC, 2009. p. 472-497.

Memória na justiça: a mobilização dos direitos humanos e a construção da memória da ditadura no Brasil. Revista Crítica de Ciências Sociais, Coimbra, n. 88, p. 127-154, 2010.

;; TELES, Edson; TELES, Janaína de Almeida (Org.). Desarquivando a ditadura: memória e justiça no Brasil. v. I e II. São Paulo: HUCITEC, 2009

SANTOS, Wanderley Guilherme dos. Estratégias de descompressão política. In:

Poder \& Política: crônica do autoritarismo brasileiro. Rio de Janeiro: Forense Universitária, 1978 [1973].

O século de Michels: competição oligopólica, lógica autoritária e transição na América Latina [1984]. In: . Paradoxos do Liberalismo: teoria e história. Rio de Janeiro: Revan, 1999.

SCANLON, T. M. Punishment and the rule of law. In: KOH, Harold; SLYE, Ronald (Ed.). Deliberative democracy and human rights. New Haven: Yale University, 1999. p. 257-271.

SCHMITTER, Phillippe C.; SANTISO, Javier. Three temporal dimensions to the consolidation of democracy. International Political Science Review, v. 19, n. 1, p. 69-92, 1998.

.; KARL, Terry L. What democracy is ... and is not. In: DIAMOND, Larry; PLATTNER, Marc F. (Ed.). The global resurgence of democracy. Baltimore: The Johns Hopkins University, 1993. p. 39-52.

SCHUMPETER, Joseph A. Capitalism, socialism and democracy. 3. ed. New York: Harper \& Brother, 1950.

SEILS, Pauls. La restauración de la confianza cívica mediante la justicia transicional. In: ALMQVIST, Jéssica; ESPÓSITO, Carlos. Justicia transicional en Iberoamérica. Madrid: Centro de Estudios Políticos y Constitucionales, 2009. p. 21-40.

SHAW, Rosalind; WALDORF, Lars. Localizing transicional justice. In: HAZAN, Pierre (Ed.). Localizing transicional justice: interventions and priorities after mass violence. Stanford: Stanford University, 2010. p. 3-26.

SIKKINK, Kathryn; WALLING, Carrie Booth. Argentina's contribution to global trends in transitional justice. In: ROHT-ARRIAZA, Naomi; MARIEZCURRENA, Javier (Ed.). Transitional justice in the twenty-first century: beyond truth versus justice. New York: Cambridge University, 2008 [2006]. 
SOARES, Inês Virginia Prado; KISHI, Sandra Akemi Chimada (Coord.). Memória e Verdade: A justiça de transição no Estado democrático brasileiro. Belo Horizonte: Fórum, 2009.

STEINER, Henry; ALSTON, Philip; GOODMAN, Ryan. International human rights in context: law, politics, morals. Oxford: Oxford University, 2008.

STEPAN, Alfred. As prerrogativas militares nos regimes pós-autoritários: Brasil, Argentina, Uruguai e Espanha. In: (Org.). Democratizando o Brasil. Rio de Janeiro: Paz e Terra, 1988.

. (Org.). Democratizando o Brasil. Introdução. Rio de Janeiro: Paz e Terra, 1988.

. On the tasks of a democratic opposition. In: DIAMOND, Larry; PLATTNER, Marc F. (Ed.). The global resurgence of democracy. Baltimore: The Johns Hopkins University, 1993. p. 61-69.

SWENSSON JUNIOR, Lauro Joppert. Punição para os crimes da ditadura militar: contornos do conflito. In: DIMOULIS, Dimitri; MARTINS, Antonio; SWENSSON JUNIOR, Lauro Joppert (Org.). Justiça de Transição no Brasil: Direito, responsabilização e verdade. São Paulo: Saraiva; Direito GV, 2010.

TEITEL, Ruti. From dictatorship to democracy: the role of transitional justice. In: $\mathrm{KOH}$, Harold; SLYE, Ronald (Ed.). Deliberative democracy and human rights. New Haven: Yale University, 1999. p. 273-290.

. Transitional Justice. Nova York: Oxford University, 2000.

. Transitional Justice Genealogy. Harvard Human Rights Journal, v. 16, 2003. Disponível em: <http://www.law.harvard.edu/students/orgs/hrj/iss16/teitel.pdf>. Acesso em: 20 dez. 2011. p. 69-94.

TELES, Edson; SAFATLE, Vladimir (Org.). O que resta da ditadura. Coleção Estado de Sítio. São Paulo: Boitempo, Coleção Estado de Sítio, 2010.

VALENZUELA, Samuel J. Democratic consolidation in post-transitional settings: notion, process, and facilitating conditions. In: MAINWARING, Scott; O'DONNELL, Guillermo; _. Samuel (Ed.). Issues in Democratic Consolidation: the New South American Democracies in Comparative Perspective. Notre Dame: University of Notre Dame, 1992. p. 57-104.

VITULLO, Gabriel Eduardo. Além da transitologia e da consolidologia: um estudo da democracia argentina realmente existente. Porto Alegre, 2005. 343 f. Tese (Doutorado em Ciência Política) - Universidade Federal do Rio Grande do Sul.

- Transitologia, consolidologia e democracia na América Latina: uma revisão crítica. Revista de Sociologia e Política, Curitiba, n. 17, p. 53-60, nov. 2001. 
WEFFORT, Francisco. Incertezas da transição na América Latina. In: MOISÉS, José Álvaro; ALBUQUERQUE, José A. Guilhon (Org.). Dilemas da consolidação da democracia. Rio de Janeiro: Paz e Terra, 1989.

Qual democracia?. São Paulo: Companhia das Letras, 1992.

WESTALL, Richard. The Sword of Damocles. 1812. Reprodução; Disponível em: $<$ http://www.unc.edu/ackland/collection/>. Acesso em: 15 jan. 2012.

WHITEHEAD, Laurence. Latin America: a new interpretation. New York: Palgrave Macmillan, 2006.

ZAFFARONI, Eugenio Raúl. Crímenes de masa. Buenos Aires: Madres de Plaza de Mayo, 2010. 